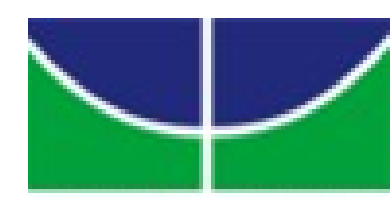

UNIVERSIDADE DE BRASÍLIA - UnB Instituto de Psicologia - IP

Departamento de Psicologia Clínica - PCL Pós-Graduação em Psicologia Clínica e Cultura

TESE DE DOUTORADO

A CRIANÇA NA DISPUTA DE GUARDA EM CONTEXTO DA AVALIAÇÃO PSICOSSOCIAL: A VOZ, O SOFRIMENTO E O ENFRENTAMENTO

MARCIA REGINA RIBEIRO DOS SANTOS

ORIENTADORA: Profa. Dra. LIANA FORTUNATO COSTA

Brasília-DF/Brasil 
INSTITUTO DE PSICOLOGIA - IP

Departamento de Psicologia Clínica - PCL

Pós-Graduação em Psicologia Clínica e Cultura

TESE DE DOUTORADO

A CRIANÇA NA DISPUTA DE GUARDA EM CONTEXTO DA AVALIAÇÃO

PSICOSSOCIAL: A VOZ, O SOFRIMENTO E O ENFRENTAMENTO

Tese apresentada ao Curso de Doutorado em Psicologia, do Instituto de Psicologia, do Departamento de Psicologia Clínica, Pós-graduação em Psicologia Clínica e Cultura da Universidade de Brasília como requisito parcial para obtenção do título de Doutora em Psicologia.

MARCIA REGINA RIBEIRO DOS SANTOS

ORIENTADORA: Profa. Dra. LIANA FORTUNATO COSTA

Brasília-DF/Brasil

2015 


\author{
INSTITUTO DE PSICOLOGIA - IP \\ DEPARTAMENTO DE PSICOLOGIA CLÍNICA - PCL \\ PÓS-GRADUAÇÃO EM PSICOLOGIA CLÍNICA E CULTURA \\ TESE DE DOUTORADO
}

\title{
A CRIANÇA NA DISPUTA DE GUARDA EM CONTEXTO DA AVALIAÇÃO PSICOSSOCIAL: A VOZ, O SOFRIMENTO E O ENFRENTAMENTO
}

Comissão Examinadora:

Profa. Dra. Liana Fortunato Costa

Instituto de Psicologia - Universidade de Brasília - Presidente

Profa. Dra. Celia Ferreira da Silva Teixeira

Universidade Federal de Goiás - Membro

Profa. Dra. Ivonete Araújo Carvalho Lima Granjeiro

Universidade Católica de Brasília - Membro

Profa. Dra. Viviane Neves Legnani

Universidade de Brasília - Membro

Profa. Dra. Maria Izabel Tafuri

Universidade de Brasília - Membro

Profa. Dra. Isabela Machado da Silva

Universidade de Brasília - (suplente) 


\section{DEDICATÓRIA}

Às crianças que me ensinaram, Às que me ensinam, Às crianças. 


\section{AGRADECIMENTOS}

A Deus, por ter me permitido existir.

Aos meus pais, Olívio (in memoriam) e Santina, por terem me dado a vida que me possibilitou conhecer, estudar e aprender.

Ao meu irmão, Paulo Eduardo, e às minhas irmãs, Erci, Alda, Vanda Cristina, pelo aprendizado da fraternidade, cooperação e compartilhamento ao longo da vida.

Ao meu marido, Wildson Luiz, por me incentivar sempre e acreditar na minha capacidade.

Aos meus filhos, Eveline, Viviane e Cristiano, por me apoiarem no desafio da realização deste trabalho, embora não soubéssemos o quão duro seria. Contudo, ficou o exemplo de persistência e coragem de jamais desistirmos diante das dificuldades no enfrentamento dos desafios em prol da individuação objetivando a totalidade.

À minha orientadora e professora, Liana, por nunca desistir de mim e me ensinar tudo o que sabe e como sabe. Muito me alegra a possibilidade de continuarmos trabalhando juntas na confecção de artigos científicos para publicação.

À minha professora da Faculdade de Educação da Universidade de Coimbra, Isabel Maria Marques Alberto, por me acompanhar quando morei naquela cidade. De acordo com o combinado, trabalharemos juntas na produção de artigos científicos. Estou ansiosa para iniciarmos a nova empreitada.

À minha amiga, Vanna Puviani, pedagoga e psicoterapeuta italiana, por me ensinar a ver nos desenhos a minha vida e a das pessoas dispostas a se (re)conhecerem por meio dos símbolos. À minha amiga, Cristiane Nunes, por compreender e pacientemente esperar a conclusão deste trabalho para seguirmos a nossa jornada.

Às minhas colegas de doutorado, parceiras de jornada, Juliana Castro e Marlene Marra, por caminharem comigo no aprendizado de ser pesquisadora. 
Ao meu colega Josimar e minhas colegas Florença e Jessica, por nos encontrarmos desde que éramos estudantes. O tempo passou, agora somos mestres! E também à Mariana Juras, Daniela Domingues e Andrea Lagares, que agora trilham esse caminho, desejando o (re)conhecimento.

Às minhas colegas de trabalho Beatriz Ros, por me permitir usufruir o tempo para estudar e compartilhar com os demais o conhecimento obtido; Luciana de Paula, pelas trocas de ideias; Vera Muniz, Maria Helena, Lia Raquel, Miriam, Cida, Mariana Sodré, Teresa Cristina, Tatianna e Ângelo, por me permitirem coletar os dados das crianças que fizeram parte da pesquisa e que se encaixavam na investigação; Mariana Sodré, Luciana Pessina, Lucineide e Cristiane Zuim que me incentivaram nesta empreitada e, também, a todos os outros colegas que trabalham no SERAF com as crianças de famílias em disputa há um bom tempo e compartilharam comigo esse aprendizado.

À Ereni pela disponibilidade, interesse e prontidão em fazer as (re)visões gramaticais dos textos que compõem esta tese.

Ao meu psicoterapeuta, José Carlos Cancelli, por me acompanhar passo-a-passo nesta jornada.

Ao meu homeopata, Dr. Basílio Borges, por me acompanhar desde o momento em que eu pensava em trilhar o caminho para o doutorado.

A todos os meus amigos de fé, do Centro Espírita Semente de Luz, em especial, Ailton e Jussara Tiscate, Inês Gomes, Zenóbia e Antonio Neres, Eny Martins, Divina Rosa, Ana Rodrigues, Isabel Cavalcante, Jeferson Costa e Christina Silva, por reconhecerem e aceitarem a minha ausência nas atividades e, ao mesmo tempo, aguardarem o meu retorno desta árdua trajetória. 
À Coordenação de Aperfeiçoamento de Pessoal de Nível Superior (Capes) por oportunizar-me a estudar fora do país e conhecer outra cultura, por meio da bolsa de doutorado sanduíche na Universidade de Coimbra.

Às professoras doutoras, Célia M. F. da S. Teixeira, da Universidade Federal de Goiás, Ivonete A. C. L. Granjeiro, da Universidade Católica de Brasília, Viviane Neves Legnani, da Universidade de Brasília, Maria Izabel Tafuri, da Universidade de Brasília, e Isabela Machado da Silva, da Universidade de Brasília, por aceitarem o desafio de examinarem este trabalho de tese com suas preciosas críticas e sugestões e, especialmente contribuírem para aprofundar o meu conhecimento nessa nova caminhada de pesquisadora, possibilitando que o conteúdo desta tese se torne ainda melhor, beneficiando o desenvolvimento de outras pesquisas nesta área.

Às famílias que possibilitaram a obtenção de informações no intuito de tornar o trabalho do profissional que atua na área da Justiça ainda melhor.

E a tantas outras pessoas que direta ou indiretamente participaram da realização deste trabalho. É difícil enumerá-las, mas considero estarem aqui contempladas, minha eterna gratidão! 


\section{EPÍGRAFE}

No desenvolvimento de uma política de participação da criança que esteja sensível a diferentes pontos de vista e percepções de crianças e pais, é importante ter atenção aos diferentes contextos nos quais as crianças podem ser envolvidas e como os problemas e preocupações sobre seu envolvimento podem ser afetados por esses contextos.

(Jude Cashmore \& Patrick Parkinson, 2008)

(Tradução livre) 


\section{RESUMO}

Esta investigação foi realizada no Tribunal de Justiça do Distrito Federal e Territórios, em uma das equipes da Secretaria Psicossocial Judiciária, onde está inserido o Serviço de Assessoramento às Varas Cíveis e de Família, que trabalha com conflitos familiares. A presente tese foi norteada pelos seguintes pontos principais: sofrimento da criança e a expressão do sofrimento da criança na Justiça. A criança consegue se expressar e comunicar seu sofrimento diferenciando o movimento que faz entre autonomia e dependência de seus pais. Ao expressá-lo na Justiça aponta, aos atores da decisão judicial, aspectos sobre o seu melhor interesse. Sendo assim, o objeto desta investigação é o sofrimento da criança em relação ao litígio familiar no contexto da avaliação psicossocial na Justiça e, o objetivo geral, foi conhecer o sofrimento da criança sobre o litígio familiar no contexto da avaliação psicossocial na Justiça. Os objetivos específicos trataram de analisar como o sofrimento da criança, vivido no contexto familiar, é expresso durante o estudo psicossocial; e quais as estratégias de enfrentamento são utilizadas pela criança na superação do seu sofrimento nos processos em que há disputa de sua guarda e que são apontadas por ela durante o estudo psicossocial. O referencial teórico teve como base o Pensamento Sistêmico, a Terapia Familiar Sistêmica e a Psicologia Jurídica. A abordagem utilizada na pesquisa foi a qualitativa. Participaram 11 crianças com idades entre 8 e 11 anos. Os instrumentos utilizados foram a entrevista semiestruturada e a confecção de desenhos. Em relação ao sofrimento surgiram três núcleos de sentido: sentimentos que expressam o sofrimento, sua origem e sua superação. A pesquisa mostrou que a criança, ao ocupar o lugar de protagonista de sua própria história, é capaz de apontar os sentimentos que envolvem seu sofrimento, a origem e as soluções que vislumbra para superá-lo quando seus pais se separam/divorciam e há conflito interparental. Quanto às estratégias, o conteúdo do discurso expresso pela criança revela-se em conhecimento de si mesma e de suas relações e do contexto em que se insere; em aprendizado, relativamente a como lidar com os impasses que vivencia; e em amadurecimento, como resultado do que conhece e aprende para abrandar o seu sofrimento, em razão das mudanças oriundas da separação/divórcio conjugal e do conflito parental/familiar existente. A expressão da criança se evidencia por meio de sua voz na revelação de posicionamentos reflexivos mediante a conjuntura da qual faz parte. Assim, a criança compreende o significado do contexto judicial, quer ser ouvida e ter a sua opinião considerada e respeitada como um sujeito de direitos, tornando-se visível nesse âmbito. Com isso, a criança deixa de ser vista apenas como vítima, para ser respeitada em suas necessidades individuais, que são próprias e únicas, e valorizada em suas capacidades, certa de que terá os seus pontos de vista incluídos, a despeito do discurso dos adultos que destacam o contexto familiar beligerante em que está inserida. Os avanços apontados pela presente pesquisa referem-se ao fato de a criança reconhecer que a sua participação contribui, de modo único e particular, no subsídio de informações para a decisão no tribunal em favor do seu bem-estar. Assim sendo, a criança compreende haver interação entre o juiz, que avalia e decide, e os profissionais que a acolhem no fornecimento de subsídios para a tomada de decisão, na busca da garantia de sua proteção. Outro avanço, é a constatação de que a criança atua como mediadora para equilibrar as relações familiares para assegurar o bem-estar de todos, desistindo de escolher entre conviver com o pai ou com a mãe, mas convicta de que receberá o amor de ambos.

Palavras-chave: sofrimento da criança, disputa de guarda, conflito parental, avaliação psicossocial. 


\begin{abstract}
The present investigation was conducted in the Federal District, at the Justice Court, with one of the General Psychosocial Judicial Office teams from the Advisory Service to Civil Courts and Family. These professionals work with family conflicts. The present thesis is guided by the following key points: children suffering and how it is expressed in the justice. Children can express and communicate their suffering by distinguishing the actions they take between autonomy and parents' dependence. When children show their suffering to the justice, they point out aspects of their main interests to the judicial decision actors. Thus, children's suffering because of family lawsuit is the object of the current investigation in the court's psychosocial evaluation context; its general aim was to understand their suffering due to the lawsuit, within the same context. The specific aim was to analyze how suffering is expressed by children living in family context during the psychosocial study; and their strategies to overcome pain. The theoretical background is the basis for Juridical Psychology and Systemic Family Therapy. The qualitative approach was used in the current study. Eleven children between 8 and 11 years old participated in the experiment. Semi-structured interviews and drawings were used as tools. Regarding suffering, there were three meaning units: feelings that express suffering, their origin and overcoming. Results show that when children are the protagonists in their own story, they are capable of pointing out feelings involving their suffering, their origin and the solutions they glimpse to overcome suffering when their parents get divorced or when there is interparental conflict. As for the strategies, the expressed speech revealed that children are aware of themselves, of their relations and of the context they live in; learning how to deal with the issues they face and ripening due to what they get to know and learn helps them to face the suffering caused by changes originated in the conjugal divorce/separation and in the existing parental/family conflict. Children's expressions are evidenced by disclosures of the reflective stances they belong to. Thus, children understand the meaning of the judicial context. They want to be heard and to have their opinion considered and respected by right and noticed within this scope. Therefore, children are no longer seen just as victims, but they seek to have their needs - which are proper and unique respected, and their capacities valued; they want to make sure that they will have their points of view accepted, despite of the adult's speeches - which reflect the messy context these children live in. The current research refers to the fact that children recognize that their participation helps, in a unique and particular way, gathering information useful to get a final court decision favorable to their welfare. Thus, children understand the interaction between the judge and the professionals who shelter them and help the decision-making process in order to ensure their protection. Within this process, children act as mediators to balance family relations and family members' welfare by abdicating the possibility of choosing to live with the father or the mother and by getting convinced that they will get love from both.
\end{abstract}

Keywords: child suffering, custody dispute, parental conflict, psychosocial evaluation. 


\section{SUMÁRIO}

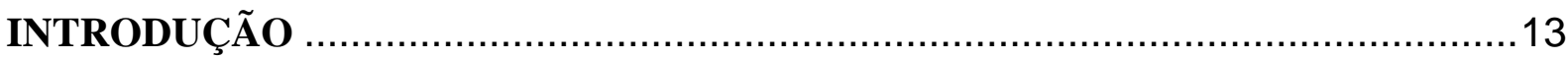

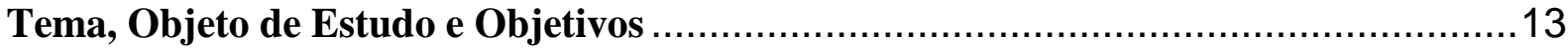

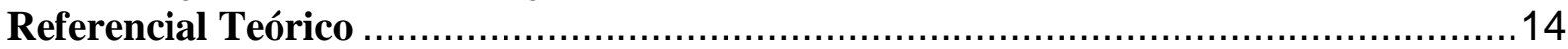

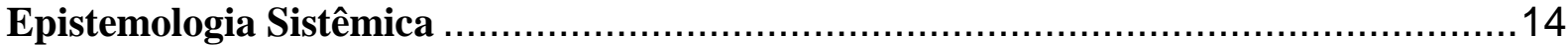

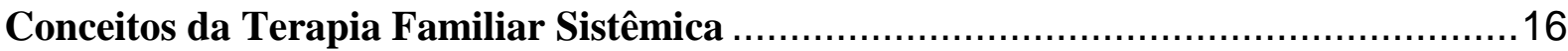

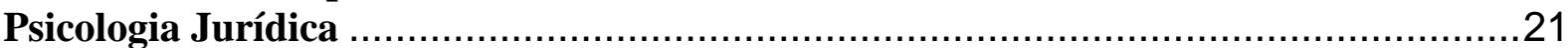

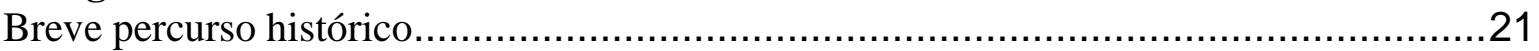

A avaliação da criança na Justiça de família .........................................................25

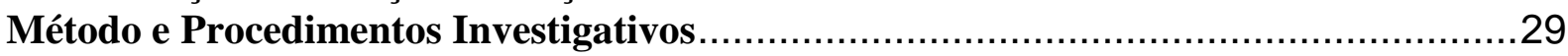

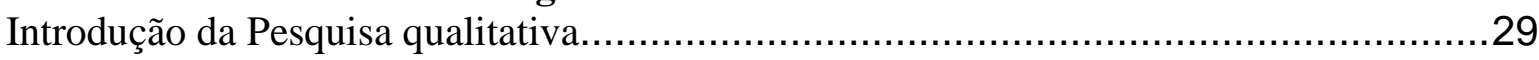

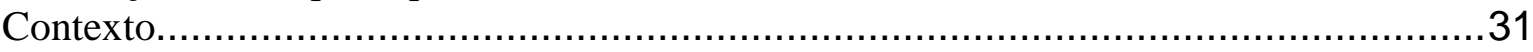

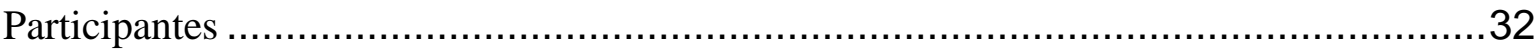

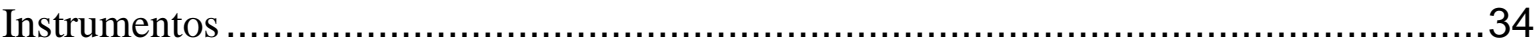

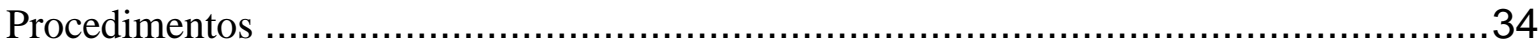

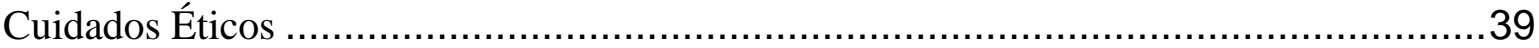

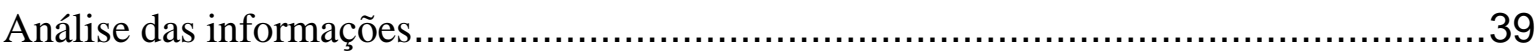

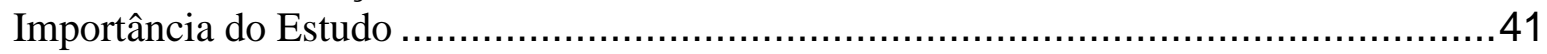

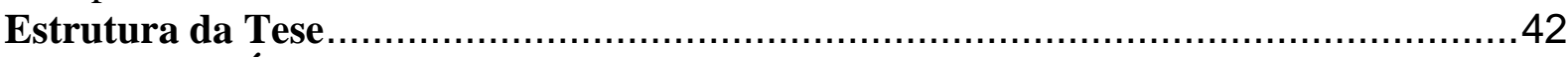

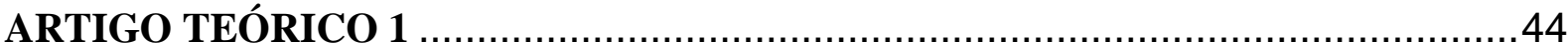

Voz da Criança na Avaliação Psicossocial em Disputas de Guarda ............................44

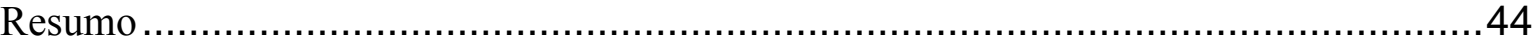

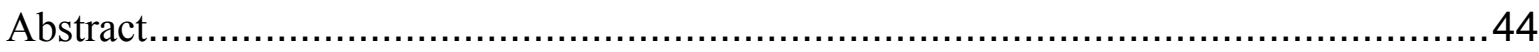

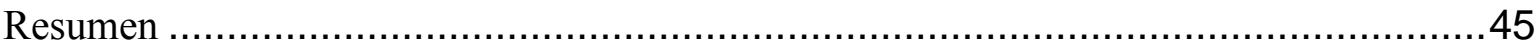

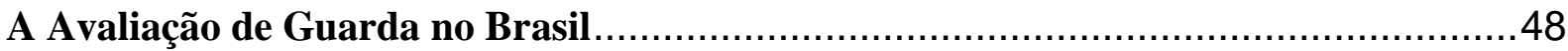

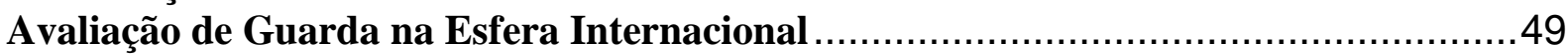

A criança como Foco nas Diretrizes que Norteiam o Trabalho de Avaliação …….........54

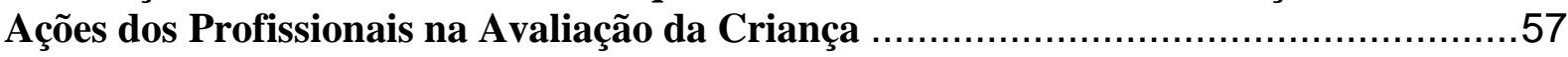

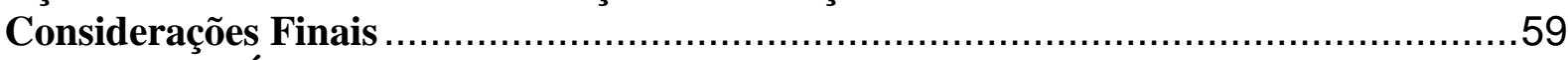

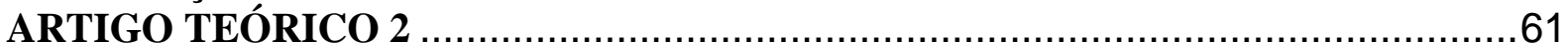

O Sofrimento da Criança na Vivência da Disputa de Guarda no Contexto da Justiça ..61

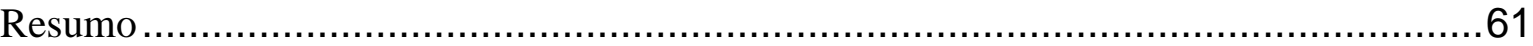

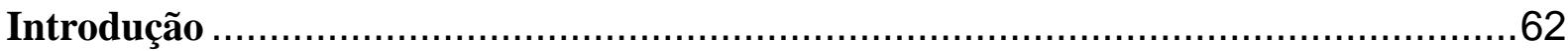

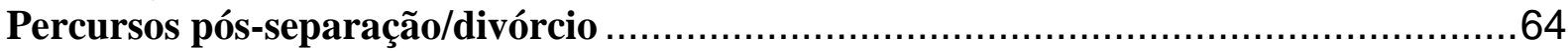

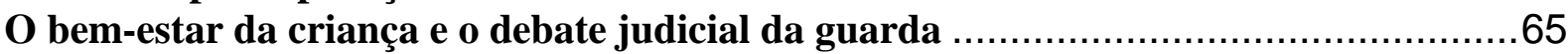

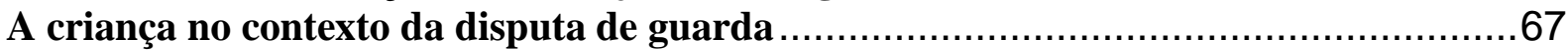

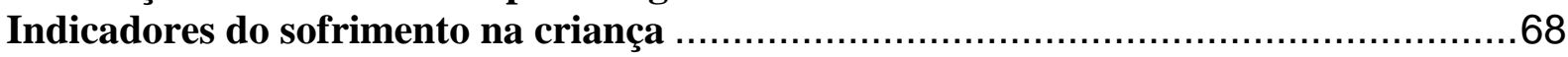

Perspetivas futuras relativas à participação da criança em contexto judicial de

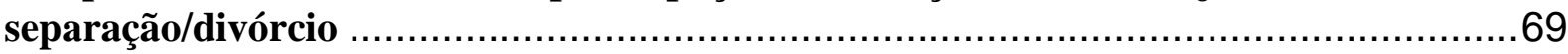

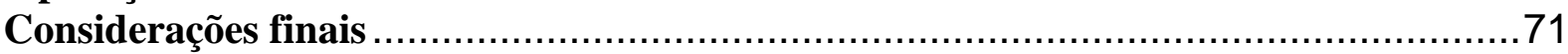

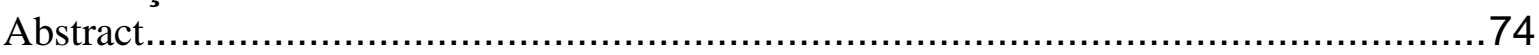

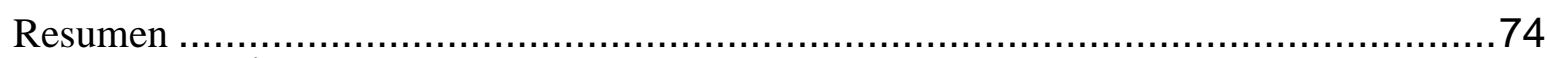

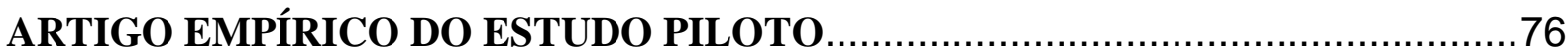

Estratégias de enfrentamento dos filhos ao conflito conjugal no contexto da Justiça ....76

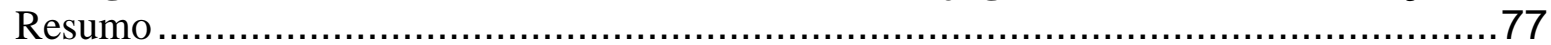

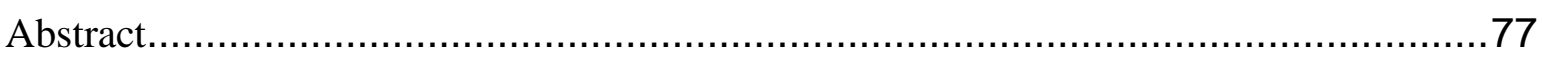

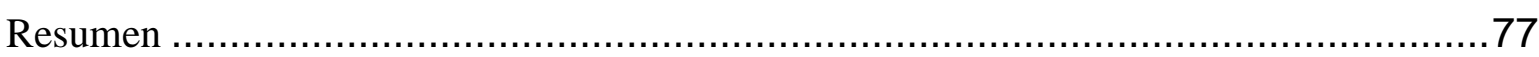

Estratégias de Enfrentamento dos Filhos ao Conflito Conjugal no Contexto da Justiça 78 


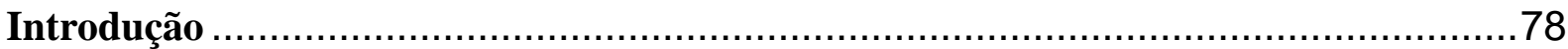

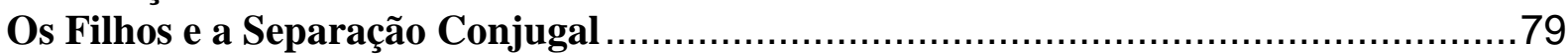

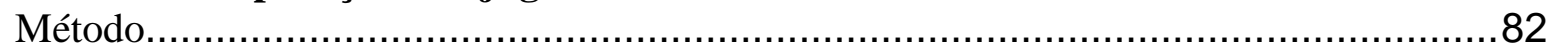

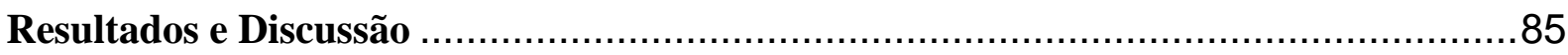

Percepção do Conflito Conjugal pelas Crianças ........................................... 86

Estratégias de Enfrentamento e Autoproteção da Criança..................................88

Apoio Mútuo dentro do Subsistema Fraternal ............................................. 90

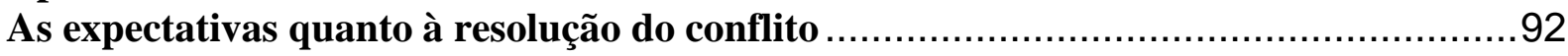

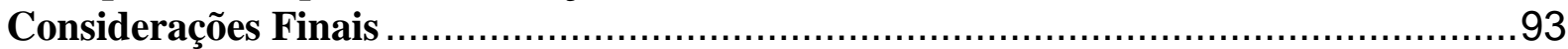

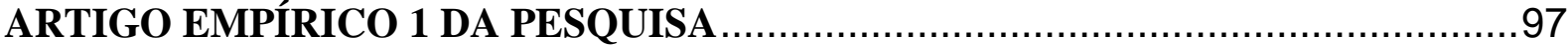

“Um Coração Partido": O Sofrimento da Criança em Disputas de Guarda .................97

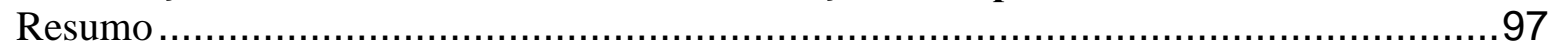

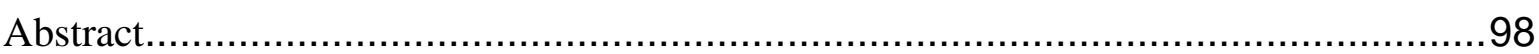

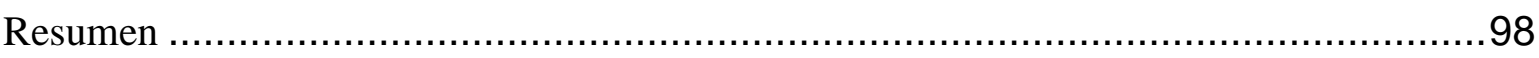

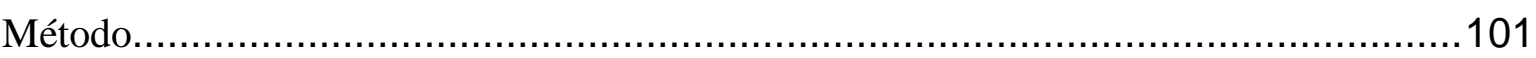

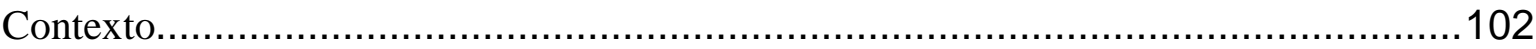

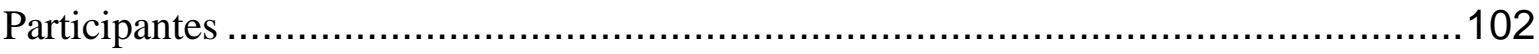

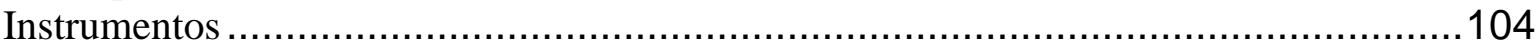

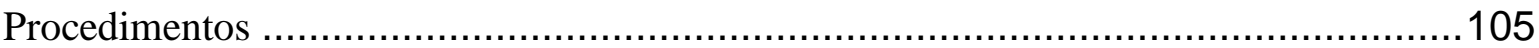

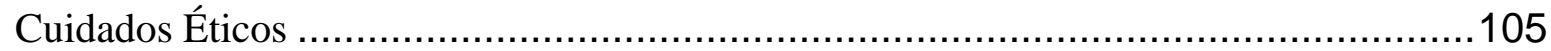

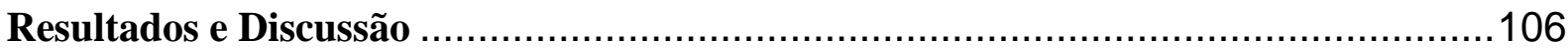

“Um Coração Partido": Sentimentos que Expressam o Sofrimento ........................106

“O que Eu Fiz de Errado"? Origem do Sofrimento ......................................... 109

“Quem Pode me Ajudar”? A Superação do Sofrimento.....................................112

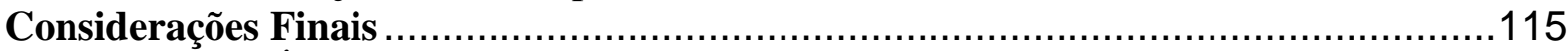

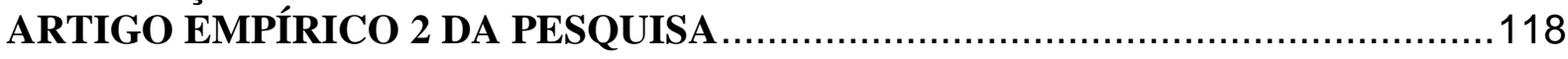

Sobrevivência da criança aos conflitos familiares em disputas de guarda ................118

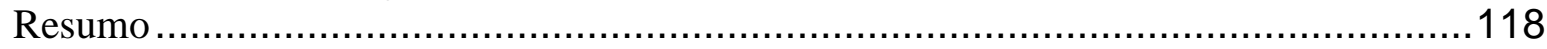

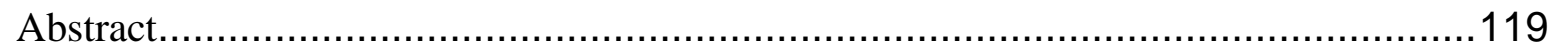

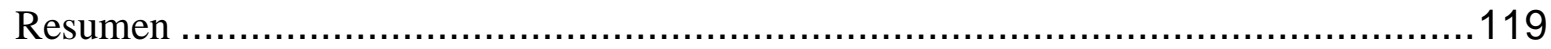

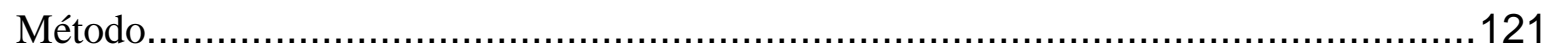

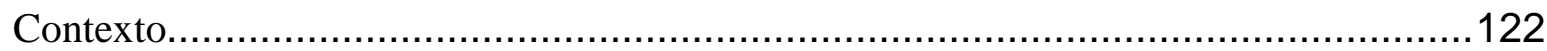

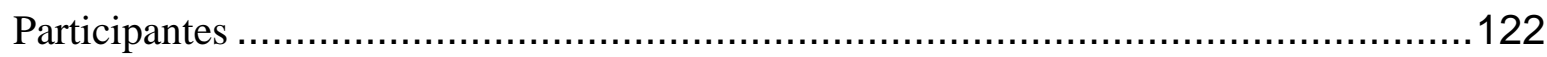

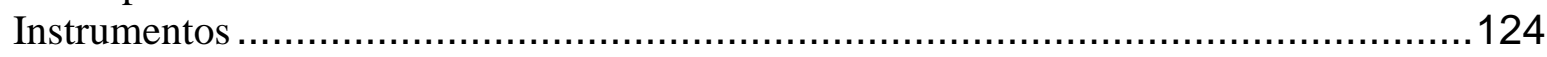

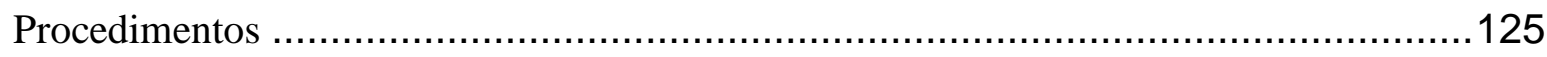

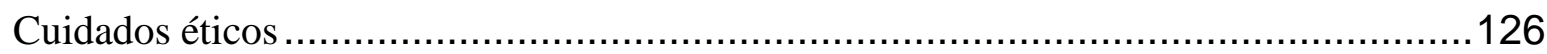

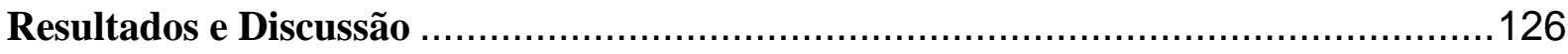

Como a Criança se Sente em Relação aos Componentes da Família ..........................126

Como a Criança se Sente em Relação a Ter que Escolher: Pai ou Mãe.....................129

Estratégias Empreendidas pela Criança para Sobreviver ao Conflito Familiar ..........131

Considerações Finais ................................................................................... 136

ARTIGO EMPÍRICO 3 DA PESQUISA .................................................. 139

Da invisibilidade à participação: a expressão da criança em disputas de guarda ........139

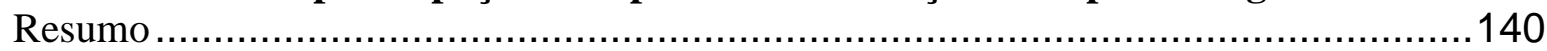

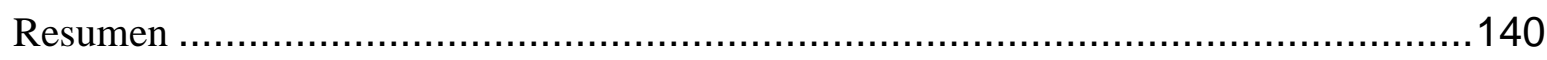

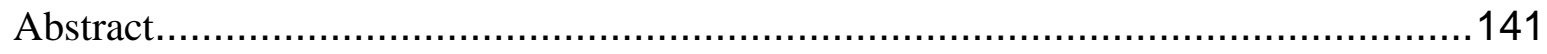

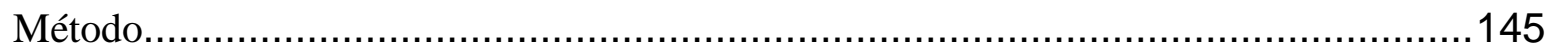

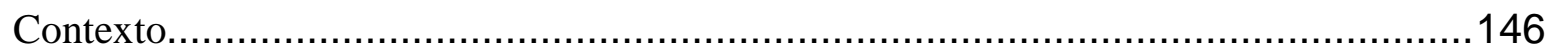

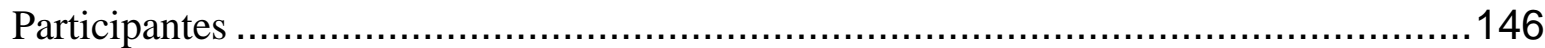

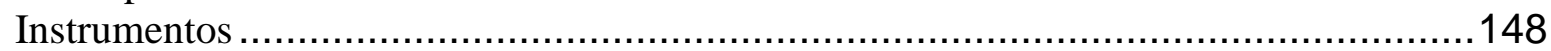




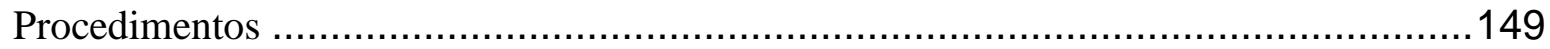

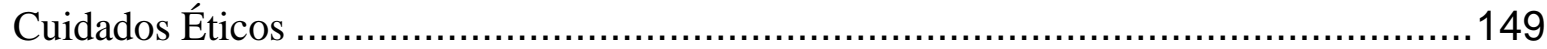

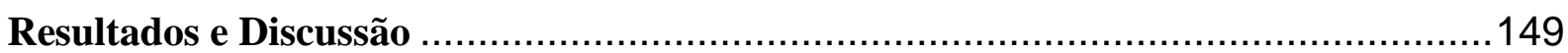

“Um Fórum é pra Decidir as Coisas": A Justiça é que Decide ...............................150

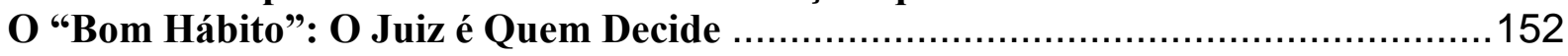

"Pode Acontecer Isso"? O Processo de Reflexão........................................... 156

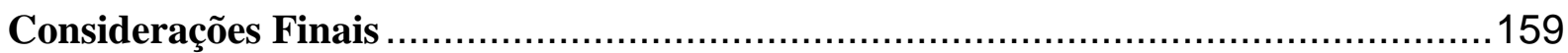

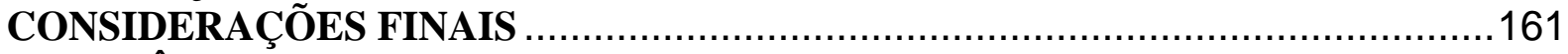

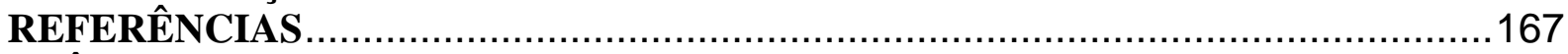

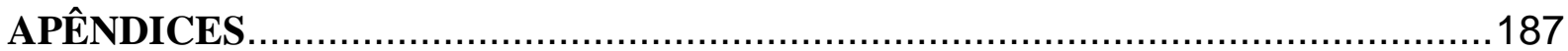

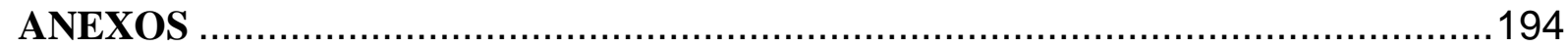




\section{INTRODUÇÃO}

A presente tese foi desenvolvida no campo de trabalho em que atuo no Tribunal de Justiça do Distrito Federal e Territórios (TJDFT) onde estou lotada no Serviço de Assessoramento às Varas Cíveis e de Família (SERAF) desde 1996. Minha atuação profissional consiste em assessorar os magistrados das varas de família, realizando estudo e avaliação psicossocial da situação de crianças, adolescentes, incapazes e suas famílias, com emissão de parecer técnico. Os processos, em geral, envolvem situações de litígio familiar sendo que, em sua maioria, o conflito é centrado no par parental. Durante todo o tempo em que exerço atividades nessa área, muitas preocupações e inquietações têm sido por mim levantadas. Uma delas se refere ao dilema entre celeridade e morosidade no trâmite processual. Esse foi meu objeto de estudo no Mestrado. No doutorado, eu e a professora Liana decidimos ouvir crianças entre 8 e 11 anos para saber como elas estavam vivendo suas experiências familiares no contexto de disputa de guarda, tendo em vista o intenso e prolongado conflito apresentado pelas famílias na Justiça. A princípio, pensamos em correlacionar a vivência da criança e o tempo nas dimensões cronológica e subjetiva durante o seu desenvolvimento enquanto há conflito dos pais na tramitação processual. Entretanto, no decorrer da investigação foram feitas mudanças substanciais até que os instrumentos atingissem a forma final para a aplicação neste trabalho, alterando-se a ideia inicial para focar no sofrimento da criança nesse âmbito.

\section{Tema, Objeto de Estudo e Objetivos}

Assim, a presente tese tem como tema dois pontos principais. O primeiro é referente ao sofrimento da criança. A criança consegue se expressar e comunicar seu sofrimento indicando o que considera seu e o que considera ser inerente à dependência dos pais, isto é, 
consegue transitar entre autonomia e interdependência; e, o segundo é relativo à expressão do sofrimento da criança na Justiça. A criança, ao expressar seu sofrimento na Justiça ajuda aos atores da decisão judicial privilegiar e decidir a partir do seu melhor interesse.

Levando em conta que o objeto deste estudo é o sofrimento da criança em relação ao litígio familiar no contexto da avaliação psicossocial na Justiça, esta tese tem como objetivo geral, conhecer o sofrimento da criança sobre o litígio familiar no contexto da avaliação psicossocial na Justiça. Os objetivos específicos são: analisar como o sofrimento da criança, vivido no contexto familiar, é expresso durante o estudo psicossocial; e analisar os recursos utilizados pela criança no enfrentamento do seu sofrimento a respeito do litígio familiar no decorrer do estudo psicossocial.

\section{Referencial Teórico}

Para fundamentar esta tese, recorreu-se a estudos oriundos principalmente do Pensamento Sistêmico, Terapia Familiar Sistêmica e Psicologia Jurídica. Essas leituras ajudaram a identificar que um caminho profícuo para conhecer o sofrimento da criança está em escutar a sua voz no contexto que envolve a disputa de sua guarda, mais do que manter-se centrado no conflito entre os adultos da família.

\section{Epistemologia Sistêmica}

O Paradigma Sistêmico proposto por Esteves de Vasconcellos (2006) norteia o trâmite da condução do trabalho apresentado. Conforme estudado pela referida autora, esse paradigma discute mudanças a partir do modelo cartesiano ou newtoniano, linear, simplificado. Os limites apresentados pelo molde tradicional não reconhecem a complexidade. Os cientistas constataram que não mais podem prever e controlar todos os fenômenos do universo, observando que os fenômenos pesquisados evidenciam resultados 
que acarretam a irreversibilidade e a incontrolabilidade. Além do mais, de acordo com essa autora, os cientistas perceberam que não era mais possível contornar ou controlar a sua subjetividade. Isso se deve ao modo de como nós somos biologicamente constituídos e como nos relacionamos com o mundo. Nesses termos, os pesquisadores constataram que "a dificuldade da objetividade não se deve à natureza do objeto do conhecimento (...) e sim à natureza do sujeito do conhecimento, como ser vivo" (p. 83). Os pesquisadores reconheceram também que “a 'realidade' emerge das distinções feitas pelo observador” (p. 83), incluindo-o em suas observações sobre o mundo.

Assim sendo, o Pensamento Sistêmico ou Paradigma da Ciência Contemporânea Emergente, proposto por Esteves de Vasconcellos (2006), transpõe os pressupostos da ciência tradicional que abarcam a simplicidade microscópica, a estabilidade e a objetividade do mundo e o realismo do universo. Passa-se, então, para o conjunto de três novos pressupostos: complexidade em todos os níveis da natureza, instabilidade do mundo em processo de tornarse, e intersubjetividade, como condição de construção do conhecimento do mundo. Assim, não existe realidade independente de um observador. O conhecimento científico do mundo é construção social a partir de espaços consensuais apresentados por diferentes observadores.

Essa mudança paradigmática traz significativas contribuições para o entendimento da interação familiar em contexto judicial, possibilitando intervenções no sistema da família que descortinem alternativas menos litigantes entre os adultos envolvidos e que contemplem o seu bem-estar. No Paradigma Sistêmico, considerar a criança como observadora do contexto familiar em que está inserida, é buscar compreender o que ela tem a dizer a partir do seu olhar, voz e expressões levando em conta a complexidade da conjuntura que se lhe apresenta. Essa conjuntura envolve a rede de sistemas na qual a criança está inserida, desde os núcleos materno e paterno, de onde ela se origina, os componentes da família extensa e pessoas de sua rede externa às quais ela recorre quando busca apoio, os profissionais do Estado que 
participam da assistência social, os profissionais da Justiça que atuam nas tomadas de decisão e contribuem para a rede de apoio e proteção da criança.

\section{Conceitos da Terapia Familiar Sistêmica}

Esta tese tem a criança como foco e considera-se importante destacar o contexto relacional familiar em que ela está inserida. De acordo com Satir (1993), o sistema familiar é o principal contexto de aprendizado para o indivíduo na expressão de comportamentos, pensamentos e sentimentos. Calil (1987) descreve que, do ponto de vista sistêmico, a família é um sistema aberto, pois os seus componentes estão em interação entre si, bem como estes e cada um com o meio ambiente. A família é um sistema total, na medida em que as ações e os comportamentos de um influencia e é influenciado pelos comportamentos dos demais. A autora pontua também que os sistemas abertos têm algumas características que devem ser consideradas. Uma é a globalidade: toda e qualquer parte está relacionada com as outras partes e qualquer mudança altera o sistema como um todo. A outra característica é a retroalimentação: a relação ocorre de modo circular, sendo que o comportamento de um membro, afeta e é afetado pelo outro. Watzlawick, Beavin e Jackson (2002), ao referirem-se à noção de função e de relação do sistema familiar, descrevem que as regras e os padrões de interação são mantidos pela retroalimentação positiva e negativa, indicando sua autorregulação. A retroalimentação positiva conduz a mudanças e, a negativa, mantém a homeostase do sistema familiar. Desse modo, à medida que a família se desenvolve, os componentes com seus estágios de desenvolvimento vão sofrendo alterações, desequilibrando o sistema e requerendo novas acomodações.

Na perspectiva estruturalista, o sistema familiar é composto por subsistemas. Segundo Minuchin (1990), Minuchin, Lee e Simon (2008), Minuchin, Nichols e Lee (2009), os componentes estão relacionados de determinadas maneiras, pressupondo-se a existência de 
vínculos. Em razão das relações, a ação de cada componente afeta e é pelo outro afetada. Ao longo do convívio, as ações e reações vão se adaptando e acomodam-se. A estrutura de organização da família está baseada em padrões repetitivos e previsíveis que envolvem filiações, tensões e hierarquias. De modo geral, as famílias têm múltiplos padrões de aliança, com pessoas emocionalmente próximas e que se apoiam mutuamente. Pai e mãe compõem o sistema parental e são responsáveis pelas tarefas referentes ao atendimento das necessidades da criança nas diferentes etapas do desenvolvimento; os filhos, o sistema filial; os irmãos, o sistema fraterno/fraternal/fratria, sendo este o primeiro laboratório social no qual as crianças podem experimentar vivências nas relações com iguais. A sobrevivência dos subsistemas depende de fronteiras invisíveis que podem ser mais ou menos permeáveis, devendo as regras e os limites entre pais e filhos serem firmes e claros, com mudanças na organização hierárquica ao longo do desenvolvimento da família. A função das fronteiras é proteger as diferenças existentes entre os membros e os subsistemas, favorecendo as competências interpessoais entre estes e o meio externo à família. Ainda conforme Minuchin (1990), os integrantes de uma família devem proteger a integridade do sistema como um todo e a autonomia funcional de suas partes para o seu saudável funcionamento. Cada componente e cada subsistema deve negociar a autonomia e a interdependência de seu psicodinamismo, sendo necessário haver flexibilidade no intercâmbio entre as fronteiras para se alcançar suficiente permeabilidade.

Minuchin (1990), Minuchin et al. (2008), Minuchin et al. (2009) destacam que, para o desenvolvimento saudável da criança, seus direitos e privilégios devem ser diferenciados de acordo com a idade e a posição que ocupa no sistema familiar. Nessa interação, a autonomia da criança pode ser promovida por meio de regras que favoreçam a sua proteção e crescimento psicossocial. Assim, à medida que a criança se desenvolve, tende a diminuir a 
dependência na relação com os pais para o favorecimento de sua emancipação psíquica/autonomia (Boszormenyi-Nagy \& Spark, 2008).

De acordo com Minuchin (1990), Minuchin et al. (2008), Minuchin et al. (2009), a família é a matriz de identidade do indivíduo. É a família que fornece a receita resultante da experiência humana de identidade, a combinação entre um sentido de pertencimento e um sentido de ser separado. De acordo com Minuchin (1990), o sentido de separação e individuação ocorre em movimento contínuo e que modela a socialização de cada membro da família. Com o passar do tempo, ocorre acomodação entre o sentido de pertencimento de uma criança ao grupo familiar no qual está inserida, havendo influência entre o sentido de pertencimento de cada membro e o sentido de pertencer a uma família específica. A acomodação da família às necessidades da criança delimita áreas de autonomia a qual é experienciada por ela como separação. Com isso, circunscreve-se o território psicológico e transacional de uma criança. Além disso, os componentes do sentido de identidade de um indivíduo mudam e permanecem constantes. Uma criança ao nascer possui parte de sua identidade a partir do fato de ser filho daquele pai e daquela mãe, ser o irmão mais novo de uma irmã e um irmão que nasceram antes dele e, quando seus pais se separam, ele continua com essa identidade, mas que poderá sofrer mudanças com a inclusão de outras pessoas em seu convívio. Estas podem ou não fazer parte de sua cultura e de sua sociedade, mas receberá a influência delas ao longo do seu desenvolvimento.

Considerou-se também fundamental, para referenciar esta pesquisa, apontar a separação conjugal/parental com enfoque sistêmico-familiar. Conforme destaca Arhons (1995), originalmente o sistema familiar é formado por um núcleo (pai, mãe e filho) e a separação pode acontecer em qualquer momento da etapa do desenvolvimento da família. Assim, a partir da separação conjugal, no que diz respeito à família com filhos, o núcleo parental formado passa a ser organizado por dois núcleos, binuclear: o materno e o paterno. 
Com a separação parental, entre as várias mudanças que ocorrem, há a decisão sobre a guarda dos filhos, quando estes são menores de 18 anos. As dificuldades, nesse contexto, surgem quando os pais adotam formas divergentes na condução da educação dos filhos, dentre outros aspectos conflitantes, podendo levar a criança a viver em um meio ambiente confuso e doloroso.

Bowen (1979) observou que os triângulos são a base dos relacionamentos e estão em constante movimento. A relação entre duas pessoas passa por ciclos de distanciamento e proximidade, sendo que quando estão distantes é que os triângulos tendem a aparecer. Satir (1993) define dois tipos de triângulo na interação familiar: o funcional e o disfuncional. Nos vértices, posicionam-se pai, mãe e filho. No triângulo funcional, o par conjugal sente confiança na relação, no disfuncional, não. No triângulo funcional, os pais são capazes de assegurar o lugar do filho, organizando-se de modo a que este não interfira na dinâmica da conjugalidade. No triângulo disfuncional, cada um se sente excluído em relação ao outro. Na guerra entre os cônjuges tanto o pai quanto a mãe podem solicitar ao filho que tome partido a seu favor e atue contra o outro genitor. A persistência em manter essa organização familiar pode gerar conflitos, pois a criança ama tanto o pai quanto a mãe e espera receber amor de ambos, necessitando interagir com eles. Entretanto, a criança se percebe em conflito ao ter que excluir um ou outro de sua vida. Mantido esse padrão interacional, os triângulos podem tornar-se desvios crônicos que corrompem e destroem os relacionamentos familiares (Bowen, 1979).

Além dos conceitos acima descritos, considera-se relevante apontar o conceito de diferenciação do self também estudado por Bowen (1979). Na diferenciação do self, o autor faz distinção entre apego ansioso e "apego funcional”. No "apego funcional” a pessoa é capaz de equilibrar pensamento e sentimento, emoções fortes e espontaneidade, lidar com a contenção e a objetividade que vem junto com a capacidade de resistir à pressão dos impulsos 
emocionais. A ausência de diferenciação entre o pensamento e o sentimento ocorre com a ausência de diferenciação entre si e os outros. A criança, por estar indiferenciada, é menos capaz de pensar com clareza, reage emocionalmente, de maneira positiva ou negativa, aos ditames dos membros da família ou de outras figuras de autoridade. Tem pouca identidade autônoma e tende a estar fusionada a outras pessoas.

Considerando que o indivíduo é a menor unidade do sistema familiar e que simultaneamente é uma entidade única e parte do todo, a criança é uma entidade sistêmica que aprende a se movimentar no triângulo primário pai, mãe e filho, tornando-se perito de relações (Andolfi, 2013). Dependendo do padrão relacional familiar, algumas disfunções podem sobrecarregar emocionalmente a criança nos períodos antes, durante e pós-separação. Nessa perspectiva, o autor esclarece que as díades mãe-filho ou pai-filho possibilitam que a criança ocupe o lugar de parceira de um de seus responsáveis. Essas díades podem ser funcionais, se ocorrerem em momentos pontuais e específicos, ou disfuncionais quando há risco para a criança, por exemplo, quando ela, de modo distorcido, assume o lugar do parceiro ausente. Outro aspecto disfuncional é quando se verifica a parentalização. A criança estará em risco emocional quando ela se enrijece no papel de cuidadora da mãe ou do pai, pois ela deveria ser protegida por ambos. Além dessas situações, quando o par parental, do ponto de vista psicológico, não se separou completamente, a criança pode ocupar o lugar de objeto dos pais. Nessas circunstâncias, os pais se mantêm unidos pela raiva, mágoa e ressentimentos havendo a intermediação da criança por ser dependente deles. A manutenção dessa organização disfuncional pode indicar fatores de perigo emocional para a criança, que se sente aprisionada na dinâmica de interação da família.

Outro conceito importante para essa investigação é o de lealdades invisíveis estudado por Boszormenyi-Nagy e Spark (2008). Para esses autores, os compromissos de lealdade caracterizam as relações familiares, sendo que o vínculo de lealdade significa mais do que um 
compromisso de confiança. Esses compromissos são ligamentos invisíveis, porém resistentes que mantêm unidos fragmentos complexos de relacionamentos, tanto nas famílias, quanto em outros grupos sociais mais amplos. Para entender os papéis, as funções e a dinâmica existentes em um dado grupo familiar, é imprescindível saber quem está unido por vínculos de lealdade e o que significa lealdade para cada um dos membros.

Ainda conforme Boszormenyi-Nagy e Spark (2008), o sistema familiar traça exigências e expectativas éticas estruturadas à criança muito antes que as obrigações se tornem conscientes. Assim, quanto mais digno de confiança for o meio, tanto mais a criança vai se tornando emocionalmente "devedora". E quanto menos puder retribuir os benefícios recebidos, maior será a dívida acumulada ao longo dos anos. A incapacidade de o indivíduo cumprir as obrigações gera sentimento de culpa que constituem forças secundárias de regulação do sistema. Desse modo, a homeostase do sistema de obrigações ou lealdade na relação familiar depende de um insumo regulador de culpas, ou seja, dos elementos que os mantém, tornando-se penosa a conservação deste ao longo da vida. Segundo esses autores, a culpa é o maior dos obstáculos para o êxito de uma emancipação psíquica verdadeiramente autônoma.

Assim, os conceitos oriundos da Terapia Familiar Sistêmica, acima descritos, contribuíram para a obtenção e posterior análise das informações obtidas nesta tese. Além desses, tendo em vista que o contexto envolve a Justiça, avaliou-se como importante recorrer ao campo da Psicologia Jurídica.

\section{Psicologia Jurídica}

\section{Breve percurso histórico}

Embora não seja alvo deste trabalho descrever a trajetória nem as controvérsias existentes relativamente à Psicologia Jurídica (Miranda Júnior, 2010), enfatiza-se a necessidade de apresentar o percurso desta área até envolver a disputa de guarda. No Brasil, 
as publicações em torno de estudos realizados na área de Psicologia Jurídica tiveram início nos primórdios da segunda metade do século XX com a tradução do Manual de Psicologia Jurídica de Mira y Lopez, que originalmente foi editado na Espanha em 1937 e reeditado na Argentina em 1945, conforme levantamento efetuado por Bomfim (1994). De acordo com essa autora, os juízes solicitavam dos psicólogos, informações para o subsídio de suas decisões. Nessa ocasião, a Psicologia passou a desenvolver pesquisas experimentais, sobre memória e percepção. As respostas dos psicólogos às solicitações judiciais tinham como base a Psicologia do Testemunho, que surgiu no final do século XIX, na relação entre a Psicologia e o Direito (Altoé, 2003), cuja interação nasceu da Psiquiatria, a partir das pesquisas sobre a loucura, no século XVIII (Jacó-Vilela, 2002). Desde então, a Psicologia Jurídica encontra-se em plena construção (Altoé, 2003; Silva, 2007; Trindade 2007).

No decorrer do desenvolvimento do trabalho do psicólogo na Justiça, da perícia passou-se ao desafio de se realizar pequenas intervenções (Brito, 2005a; França, 2004; Granjeiro \& Costa, 2008; Lima, 2003; Miranda Júnior, 1998). Ainda, segundo Miranda Júnior (2010), há três posições diferentes quanto ao embasamento teórico dos estudiosos e profissionais nesse campo: um grupo defende o trabalho de perícia, inserindo-se psicólogos que utilizam testes para a avaliação; o outro, que recorre à psicanálise e teoria sistêmica, defende a escuta da singularidade e intervenção na dinâmica familiar; e o terceiro, oscila entre os dois grupos de profissionais. A partir dessas dissonâncias, os pesquisadores e profissionais do segundo grupo, que recorrem à teoria sistêmica, foram percebendo que, no atendimento à demanda judicial especialmente relacionada às varas de família, era necessário que, na interface com a Justiça, a Psicologia e o Serviço Social em especial, buscasse junto ao Direito uma atuação que promovesse a interdisciplinaridade (Lima, 2003). Optou-se por conceituar a interdisciplinaridade de acordo com Vasconcelos (2004), por melhor se adequar ao que se pretende discorrer a seguir. Assim sendo, de acordo com esse autor, interdisciplinaridade 
significa "a interação entre as diversas fronteiras de saber" (p. 111), a qual promove mudanças estruturais, buscando a reciprocidade e o enriquecimento mútuo, tendendo a tornar horizontal as relações de poder entre as áreas envolvidas.

Para Costa, Penso, Legnani e Sudbrack (2009), o psicólogo jurídico realiza estudo que envolve olhar compreensivo sobre o discurso apresentado considerando o contexto judicial. No entanto, tal estudo não se restringe aos aspectos psicológicos nem psicopatológicos, mas também, sociais. As pesquisadoras, ao fazerem a interseção entre as duas dimensões, ampliam o ponto de vista, antes restrito a uma área, para incluir a outra e a denominam de psicossocial. Segundo essas autoras, a ampliação redimensiona o trabalho do psicólogo, potencializando os aspectos interventivos. Pessina e Mendes (2012) afirmam que o estudo psicossocial não logra sobrepujar nem suprimir "diferenças e especificidades, a homogeneização dos conhecimentos e práticas ou a negação da tensão presente entre as duas áreas" (p. 65). As autoras explicitam que o estudo psicossocial visa à construção de linguagem e metodologia que ampliem a compreensão sobre as famílias atendidas de modo que estas possam retomar suas competências, que foram transferidas para a Justiça e nela depositadas, para a resolução das dificuldades expostas. Portanto, o curso que vem sendo traçado pela Psicologia Jurídica, no âmbito nacional e que abarca a perspectiva psicossocial, tornou-se fundamental a fim de contribuir para as reflexões na presente tese.

Na Europa, Shaw, Öhman e van Koppen (2013) informam que a Psicologia e o Direito têm se expandido nas últimas décadas. De acordo com esses autores, as pesquisas tiveram início com estudos relativos aos testemunhos com alemão Wilhelm Stern (1871-1938) na primeira década do século XX. Em Portugal, apesar do desenvolvimento vertiginoso, há pouco consenso nos estudos dessa área (Gonçalves, 2012; Manita \& Machado, 2012). A Psicologia da Justiça, que engloba o conjunto de saberes oriundos da Psicologia aplicados à compreensão, avaliação ou intervenção nos diversos fenômenos definidos pela aplicação da 
Justiça, divide-se em Psicologia Criminal e Psicologia Forense. A primeira centra-se no estudo do crime e do criminoso, suas causas, dinâmicas, processos e consequências, modalidades de prevenção e intervenção. A segunda é um ramo da Psicologia que diz respeito à obtenção, exame e apresentação da prova para fins judiciais nos casos que envolvem o direito civil, de família, do trabalho. No Direito de Família, a Psicologia Forense tem variados domínios, incluindo-se o de pais e filhos envolvidos em processos de regulação do exercício das responsabilidades parentais. Nesse âmbito, os estudiosos foram criando protocolos, metodologias e instrumentos de avaliação psicológica para fins periciais que objetiva atender à demanda relativa à decisão judicial.

Também no século XX nos Estados Unidos, conforme descreve Huss (2009), o sistema legal recorria à Psicologia para a obtenção de resultados que consideravam justos, sendo que na primeira década, a prática clínica da Psicologia Forense envolveu a avaliação e o tratamento de delinquentes juvenis. Atualmente, segundo o referido autor, a prática da Psicologia Forense abarca as áreas do Direito Criminal e Civil, com aplicação da Psicologia Clínica ao sistema legal, havendo intenso debate quanto a sua natureza, tal como ocorre em outros países. No Direito Civil são tratados os processos de guarda e responsabilidade, além de outros nessa área. Desde a década de 1970 o padrão de avaliação da criança passou a ser considerado a partir do princípio do melhor interesse da criança, o qual se baseia no seu desenvolvimento e maturidade. Para tanto, instituíram-se critérios tidos como relevantes para a análise da guarda. Para citar alguns resumidamente: saúde física e mental da criança e familiares; adaptação da criança à casa, escola e comunidade; condições dos pais no atendimento às necessidades da criança; interação da criança com os familiares e outros; os desejos dos pais e da criança; outros aspectos considerados relevantes pelo tribunal. Além disso, a Associação Americana de Psicologia (APA) instituiu diretrizes para a prática 
profissional em 1994 modificadas e atualizadas em 2010, que também serve de referência para psicólogos canadenses.

No breve percurso acima descrito, verifica-se que os estudos apontam diferenças de enfoque utilizadas pelos profissionais e investigadores tanto no Brasil quanto no Exterior. Contudo, para esta tese, utilizou-se a vertente que aborda a interdisciplinaridade entre os saberes científicos com o enfoque psicossocial, pois potencializa os aspectos interventivos, contemplando elementos que ampliam o espectro tanto para a obtenção das informações quanto da análise e discussão destas. Entretanto, é necessário destacar as pesquisas referentes à avaliação da criança nesse âmbito.

\section{A avaliação da criança na Justiça de família}

Conforme apontam Fuhrmann e Zibbell (2012), Sthal (2011), Huss (2009) nos séculos XVI e XVII a criança era de domínio paterno e era considerada espólio ativo para a economia da família. Com o aumento da taxa de divórcio nos Estados Unidos passou-se a considerar a inata habilidade materna. No início do século XX, progressivamente houve mudança para o apoio aos interesses da criança, a partir de casos que envolviam aspectos morais em relação à mãe.

Na segunda metade do século XX, a Convenção sobre os Direitos da Criança (UNICEF, 1990) passou a considerar que todas as decisões referentes à criança, oriundas de entidades públicas ou privadas que tratem da proteção social e jurídica, deveriam atender ao melhor interesse da criança. Esse princípio se tornou ponto fundamental para que as nações buscassem meios de observarem o atendimento das necessidades da criança. No Brasil, a Constituição Federal, promulgada em 1988; a Lei no 10.406 de 10 de janeiro de 2002, referente ao Código Civil; e a Lei n ${ }^{\circ} 8.069$ de 13 de julho de 1990, relativa ao Estatuto da Criança e do Adolescente (ECA) normatizam a garantia do atendimento ao melhor interesse 
da criança e objetivam nortear a ação das instituições públicas, pois ela depende de adultos responsáveis para auxiliá-la a desenvolver-se. Esse princípio deve ser incorporado e cumprido pela família, pela sociedade e pelo Estado. Isso, porém, não significa o atendimento restrito aos desejos da criança, mas garantir os seus direitos. O melhor interesse da criança vincula-se “ao estabelecimento de limites, à disposição para receber educação, ao respeito à autoridade dos pais e professores, ao conhecimento de noções de responsabilidade e ao respeito às regras sociais" (Kreuz, 2012, p. 73).

Em consonância com as diretrizes constitucionais, o Conselho Federal de Psicologia publicou um documento que trata das Referências Técnicas para Atuação do Psicólogo em Varas de Família (CFP, 2010). Esse documento esclarece que o profissional poderá utilizar as abordagens teóricas disponíveis na área, sendo que o trabalho envolverá "estudos sobre famílias contemporâneas, cuidados parentais, relacionamento entre pais e filhos, relações de gênero, desenvolvimento infanto-juvenil, entre outros". O citado documento esclarece, também, que haja evidências de precisão e validade no atendimento psicológico no âmbito jurídico na audição da criança, seus familiares e pessoas de sua referência, compreendendo-a na dimensão sociofamiliar. Percebe-se, portanto, com base na Convenção sobre os Direitos da Criança (UNICEF, 1990) e nas Referências Técnicas para Atuação do Psicólogo em Varas de Família (CFP, 2010), que cabe ao profissional utilizar-se dos recursos técnico-científicos disponíveis para garantir os direitos da criança, resguardando seus interesses precípuos a fim de favorecer sua expressão a respeito de questões que estão diretamente a ela vinculadas.

No Brasil, os estudos de família na Justiça com enfoque na disputa de guarda e regulamentação de visita, Lago e Bandeira (2013) mostram a importância de o profissional considerar os vínculos afetivos saudáveis ao desenvolvimento da criança, além de ser necessário o conhecimento em Direito de Família. Para tanto, com base em estudos da última década, consideraram válida a construção de um Sistema de Avaliação do Relacionamento 
Parental (SARP) no âmbito de disputa de guarda. As pesquisadoras verificaram que os profissionais não seguem padrão comum de avaliação em virtude das peculiaridades de cada família que busca a Justiça. Desse modo, o referido SARP é um sistema de técnicas que avalia a qualidade do vínculo entre pais e filhos, podendo ser utilizado por psicólogos, assistentes sociais e psiquiatras quando necessitarem subsidiar recomendações de guarda e visitas determinadas pelo juiz.

O norte-americano Ackerman (2006), partindo de mais de duas décadas de estudos, destaca que, para a avaliação de guarda, com base no princípio do melhor interesse da criança, é necessário realizar observação dos comportamentos dos participantes e entrevista com a criança e familiares, inclusive de terceiros. Para tanto, estabeleceram-se diretrizes para promover a qualidade da avaliação. Além disso, pode-se recorrer aos testes psicológicos quando as informações obtidas forem insuficientes. Dentre os testes recomendados, encontram-se o de inteligência, o de personalidade, testes projetivos e de completamento de frases. Tais testes podem ser aplicados tanto em crianças quanto em adultos. Grisso (2003), outro norte-americano, tal como Ackerman, realiza pesquisas há mais de duas décadas, enfocou a avaliação das competências legais dos indivíduos, aprimorando os instrumentos utilizados no contexto judicial. Nos casos de disputa de guarda, os referidos autores defendem que os profissionais recorram a escalas e protocolos construídos para avaliar as competências parentais no atendimento às necessidades dos filhos. O intuito dessa avaliação é obter informações que subsidiem o tratamento, se for o caso. Para Grisso, as características a serem observadas nas crianças são: idade e sexo, ajustamento nas mudanças (incluindo tempo com o pai e com a mãe); história da criança (vítima de abusos sexual, emocional, por exemplo); necessidades educacionais; saúde mental ou tratamento medicamentoso; desejo de local de moradia e com quem quer residir, se tiver idade suficiente para se manifestar; efeitos da separação nos irmãos, se houver. Nos pais, deve-se observar: história de abusos por parte do 
parceiro/cônjuge; status econômico; interesse e desejo de obtenção da guarda; saúde física e mental; uso de drogas; nível de hostilidade entre o par; flexibilidade; habilidades parentais; cuidados antes e depois da separação em relação ao filho.

Emery, Rowen e Dinescu (2014), também norte-americanos, insatisfeitos com o sistema adversarial do "perder x ganhar", que acarreta prejuízo aos filhos, pois acirra o conflito coparental, buscam contribuir com enfoque em outros aspectos dos sujeitos que vivenciam a disputa de guarda. Para tanto, entendem que a mediação pode contribuir com a família nas negociações em relação às mudanças que estão ocorrendo em sua organização. A mediação é um método de resolução no qual quem disputa encontra com a terceira parte do vértice do triângulo, considerado neutro, que facilita o processo de negociação e coordena o conteúdo em pauta relativo ao acordo, objetivo precípuo dessa intervenção. O mediador não tem autoridade para decidir, mas pode orientar os componentes da família que buscam essa abordagem para resolver suas querelas na Justiça. Os autores acreditam que os mediadores com formação em Terapia Familiar Sistêmica poderão contribuir para uma Justiça menos adversarial e mais cooperativa, em razão de técnicas interventivas que favorecem mudanças para os participantes cooperarem com as transformações na organização da família. Os referidos autores distinguem a mediação facilitadora (focada no processo), a avaliativa (o mediador faz sugestões e ajuda ativamente os pais em diferentes opções); e a transformativa (além de negociar o acordo, também transforma o relacionamento entre os disputantes).

Assim sendo, na diversidade descrita concernente à avaliação da criança no contexto de disputa de guarda, verifica-se que, no âmbito nacional, publicações de pesquisas nesse campo, que enfocam a qualidade do vínculo entre pais e filhos, são relativamente recentes (Lago \& Bandeira, 2013). A partir dos estudos realizados no exterior e no Brasil, entende-se que as avaliações têm evoluído com foco no saudável desenvolvimento da criança, conforme preconiza a legislação. Nessa sequência, o Paradigma Sistêmico pode também contribuir tanto 
com o pesquisador quanto com o profissional os quais estudam e realizam a avaliação da criança em contexto de disputa de guarda.

\section{Método e Procedimentos Investigativos}

\section{Introdução da Pesquisa qualitativa}

A abordagem adotada nesta pesquisa foi qualitativa, isto é, utiliza a interpretação nas Ciências Sociais (Bauer, Gaskell, \& Allum, 2010) com uso ampliado para a Psicologia (Silveira \& Córdova, 2009). Segundo Creswell (2010), a pesquisa qualitativa visa a explorar e a entender o significado de algum problema relatado por indivíduos ou grupos. Nesse enfoque, as informações são obtidas no ambiente natural dos participantes. As interações face a face propiciam que emerjam questões e procedimentos cuja análise vai sendo construída de modo indutivo, criando seus próprios padrões, categorias e temas. Fica a cargo do pesquisador a interpretação dos significados expressos pelos participantes na questão a ser pesquisada. $\mathrm{O}$ investigador pode utilizar um protocolo criado por ele próprio como instrumento para a obtenção de subsídios. Além disso, pode empregar observações e documentos como outras fontes de informações. A pesquisa qualitativa é a interpretação do pesquisador em relação ao que enxerga, ouve e entende, oferecendo múltiplas visões que podem emergir da questão que está sendo investigada. $\mathrm{O}$ pesquisador busca desenvolver um quadro complexo do problema a ser pesquisado com múltiplas perspectivas e dos vários fatores que envolvem a situação em estudo.

Para Flick (2009), um dos aspectos essenciais na pesquisa qualitativa consiste na produção de conhecimento oriundo das reflexões efetuadas pelo pesquisador ao longo da investigação, evitando que seus preceitos e crenças interfiram na pesquisa. A importância da pesquisa qualitativa é tê-la como possibilidade de dar voz às pessoas/participantes, valorizando seus pensamentos e expressões e considerando-as como sujeito que tem algo importante a dizer no processo de investigação que está sendo abordado (Bauer et al., 2010). 
Gaskell (2010) esclarece que na pesquisa qualitativa usa-se a entrevista semiestruturada para o fornecimento de informações básicas para o desenvolvimento e a compreensão das relações entre os participantes e o seu contexto. A entrevista pode ter um único respondente ou um grupo de respondentes, também denominado grupo focal. A entrevista qualitativa visa a compreender, de modo detalhado, as crenças, atitudes, valores e motivações relativamente aos comportamentos das pessoas em ambientes específicos. $\mathrm{Na}$ preparação e planejamento da entrevista semiestruturada, as questões centrais são o tópico guia (o que perguntar) e como selecionar os entrevistados (a quem perguntar).

O tópico guia, conforme descreve Gaskell (2010), funciona como um lembrete para o entrevistador de que há uma agenda a ser seguida, auxilia no monitoramento do tempo da entrevista e deve ser usado com flexibilidade. Mudanças poderão ocorrer ao longo da aplicação da entrevista e tudo deverá ser registrado com as explicações sobre os motivos das alterações. De acordo com esse autor, a finalidade da pesquisa qualitativa é explorar o espectro de opiniões, as diferentes representações sobre o assunto em pauta, maximizando a oportunidade de compreensão das diversas posições dos membros escolhidos para a realização da pesquisa. Os critérios devem ser especificados e os procedimentos e as escolhas detalhados e justificados. O número de entrevistas dependerá da natureza do tema a ser abordado, do número dos diferentes ambientes envolvidos e dos recursos disponíveis.

De acordo ainda com Gaskell (2010), um dos aspectos principais a ser observado é que há um número limitado de versões da realidade que, embora pareçam únicas ao indivíduo, são resultados de processos sociais. Assim, temas comuns surgem nas entrevistas e aos poucos o fenômeno é compreendido. Em certo momento, o entrevistador percebe que não haverá mais novidades, identifica que o tópico guia não é mais necessário e verifica que compreendeu o fenômeno, pois chegou ao ponto de saturação do sentido. O outro aspecto é o tamanho do corpus a ser analisado, sendo que uma entrevista pode ter até 15 páginas. 
Considerando 20 entrevistas, haverá 300 páginas. Por essas razões, o limite no número máximo de entrevistas individuais é entre 15 e 20.

Conforme esclarece Gaskell (2010), escolha pela entrevista individual ou em grupo se embasa no fato de que toda pesquisa com entrevistas é um processo social em que as palavras são o meio principal de troca. É uma interação, com troca de significados em que várias realidades e percepções são exploradas e desenvolvidas, embora entrevistador e entrevistado estejam envolvidos na produção de conhecimento de maneiras diferenciadas. Na interação da díade entrevistador - entrevistado, a entrevista pode durar mais de uma hora e a conversação ocorre entre duas pessoas desconhecidas entre si. O esperado é o entrevistador perguntar e o entrevistado responder questões que possivelmente não havia pensando antes da ocorrência da entrevista. Por essa razão, há necessidade do estabelecimento de uma relação de confiança por meio do encorajamento do entrevistador para deixar o entrevistado à vontade. $\mathrm{O}$ entrevistador deve ser aberto e descontraído em relação à gravação que pode ser justificada como um registro útil para posterior análise.

\section{Contexto}

O contexto de realização da pesquisa foi o TJDFT, que contempla a SEPSI, subdividida em duas Subsecretarias, sendo que uma delas é responsável pelo Serviço de Assessoramento às Varas Cíveis e de Família (SERAF). Esse setor atende famílias encaminhadas por determinação do juiz de direito e atualmente é composto por uma supervisora, com formação em Serviço Social, assistentes sociais, psicólogos e estagiários de Psicologia. Essa equipe está localizada no Fórum Desembargador Leal Fagundes e atende à circunscrição de Brasília-DF. Nos Fóruns de Taguatinga-DF e de Sobradinho-DF há outras duas equipes compostas por assistentes sociais e psicólogos, além de estagiários de Psicologia. Ressalta-se que esta pesquisa utilizou recursos/instrumentais elaborados especificamente para a obtenção das informações que posteriormente foram analisadas. 
A pesquisa ocorreu nas salas destinadas ao atendimento das famílias onde está localizado o SERAF nas dependências dos Fóruns de Brasília e de Taguatinga. Importante enfatizar que essas salas estão equipadas com material lúdico tais como: jogos, carrinhos, bonecos, casinhas, fantoches, papel, canetas coloridas, tubos de cola, tesouras, cartolina, fita crepe e revistas para serem recortadas. Inclui ainda, cadeiras para acomodar os componentes da família, bem como uma pequena mesa para apoio quando da utilização dos jogos, da colagem e na confecção de desenhos. A sala onde se localizam os profissionais desse Serviço foi o espaço físico utilizado para a leitura dos processos selecionados. Nessa sala, manteve-se conversação com os profissionais responsáveis pelos casos, conhecendo-se a organização dos atendimentos previstos que foram acompanhados e registrados para utilização nesta pesquisa.

\section{Participantes}

Os participantes da pesquisa foram 11 crianças pertencentes às famílias vinculadas ao processo judicial, com idades entre 8 a 11 anos. A descrição consta na Tabela 1 na próxima página. O principal indicativo para a seleção dos casos que fizeram parte da pesquisa foi o fato de a dinâmica envolver disputa familiar, contexto no qual a criança está inevitavelmente inserida quando seus familiares recorrem à Justiça para tratar da guarda, regulamentação de visita, modificação de cláusula de guarda e/ou de visita. 


\section{Tabela 1}

Informações das Crianças Participantes da Pesquisa e da Ação Judicial por Família

\begin{tabular}{|c|c|c|c|c|c|c|c|c|}
\hline \multirow[b]{2}{*}{$\begin{array}{l}\text { Famí- } \\
\text { lia }\end{array}$} & \multicolumn{4}{|c|}{ Informações sobre as crianças } & \multicolumn{4}{|c|}{ Ação judicial } \\
\hline & Nome & $\begin{array}{l}\text { Idade/ } \\
\text { sexo }\end{array}$ & $\begin{array}{l}\text { Ano } \\
\text { esco- } \\
\text { lar }\end{array}$ & $\begin{array}{l}\text { Reside } \\
\text { com }\end{array}$ & Tipo & $\begin{array}{l}\text { Movida } \\
\text { por }\end{array}$ & Contra & Motivo \\
\hline F1 & Jaspe & $\begin{array}{l}11 / \\
M\end{array}$ & $6^{\circ}$ & $\begin{array}{l}\text { Pai e } \\
\text { Irmã (13 } \\
\text { anos) }\end{array}$ & RDUE & Pai & Mãe & $\begin{array}{l}\text { Violência } \\
\text { interparental, } \\
\text { uso abusivo de }\end{array}$ \\
\hline & Ônix & $\begin{array}{l}8 / \\
M\end{array}$ & $3^{\circ}$ & $\begin{array}{l}\text { Mãe e } \\
\text { irmã (4 } \\
\text { anos) }\end{array}$ & & & & $\begin{array}{l}\text { álcool e } \\
\text { negligência dos } \\
\text { filhos. }\end{array}$ \\
\hline F2 & Jasmim & $\begin{array}{l}9 / \\
\mathrm{F}\end{array}$ & $3^{\circ}$ & $\begin{array}{l}\text { Mãe e } \\
\text { irmão } \\
(13 \\
\text { anos) }\end{array}$ & GR & Mãe & Pai & $\begin{array}{l}\text { Mãe suspeita de } \\
\text { abuso sexual da } \\
\text { filha na casa } \\
\text { paterna por } \\
\text { enteados. }\end{array}$ \\
\hline F3 & Ágata & $\begin{array}{l}10 / \\
\mathrm{F}\end{array}$ & $5^{\circ}$ & $\begin{array}{l}\text { Mãe e } \\
\text { avós } \\
\text { mater- } \\
\text { nos }\end{array}$ & RV & $\begin{array}{l}\text { Avós } \\
\text { paternos }\end{array}$ & Mãe & $\begin{array}{l}\text { Visitas do pai à } \\
\text { filha suspensas } \\
\text { judicialmente } \\
\text { por abuso } \\
\text { sexual } \\
\text { comprovado. }\end{array}$ \\
\hline F4 & Mirtilo & $\begin{array}{l}9 / \\
\mathrm{M}\end{array}$ & $3^{\circ}$ & $\begin{array}{l}\text { Mãe, } \\
\text { compa- } \\
\text { nheiro e } \\
\text { um } \\
\text { irmão } \\
\text { unilate- } \\
\text { ral (6 } \\
\text { anos) }\end{array}$ & $\mathrm{AG}$ & $\begin{array}{l}\text { Avós } \\
\text { maternos } \\
\text { mãe e pai }\end{array}$ & Não há & $\begin{array}{l}\text { Benefícios em } \\
\text { plano de saúde } \\
\text { e bolsa de } \\
\text { estudos para } \\
\text { língua } \\
\text { estrangeira. }\end{array}$ \\
\hline F5 & Berilo & $\begin{array}{l}8 / \\
M\end{array}$ & $2^{o}$ & $\begin{array}{l}\text { Mãe e } \\
\text { irmã (14 } \\
\text { anos) }\end{array}$ & $\mathrm{RV}$ & $\begin{array}{l}\text { Avó } \\
\text { paterna }\end{array}$ & Mãe & $\begin{array}{l}\text { Pai falecido } \\
\text { após a } \\
\text { separação } \\
\text { conflituosa. }\end{array}$ \\
\hline F6 & Yacón & $\begin{array}{l}9 / \\
\mathrm{M}\end{array}$ & $4^{o}$ & $\begin{array}{l}\text { Pai e } \\
\text { compa- } \\
\text { nheira }\end{array}$ & RV & Pai & Mãe & $\begin{array}{l}\text { Acusação de } \\
\text { maus tratos } \\
\text { físicos e } \\
\text { psicológicos } \\
\text { durante as } \\
\text { visitas na casa } \\
\text { materna. }\end{array}$ \\
\hline F7 & $\begin{array}{l}\text { Esme- } \\
\text { ralda }\end{array}$ & $\begin{array}{l}10 / \\
\mathrm{F}\end{array}$ & $5^{\circ}$ & $\begin{array}{l}\text { Mãe, } \\
\text { avó e tio } \\
\text { mater- } \\
\text { nos }\end{array}$ & $\mathrm{RV}$ & Mãe & Pai & $\begin{array}{l}\text { Pedido de } \\
\text { suspensão das } \\
\text { visitas por } \\
\text { acusação de } \\
\text { abuso sexual } \\
\text { pelo pai e }\end{array}$ \\
\hline
\end{tabular}




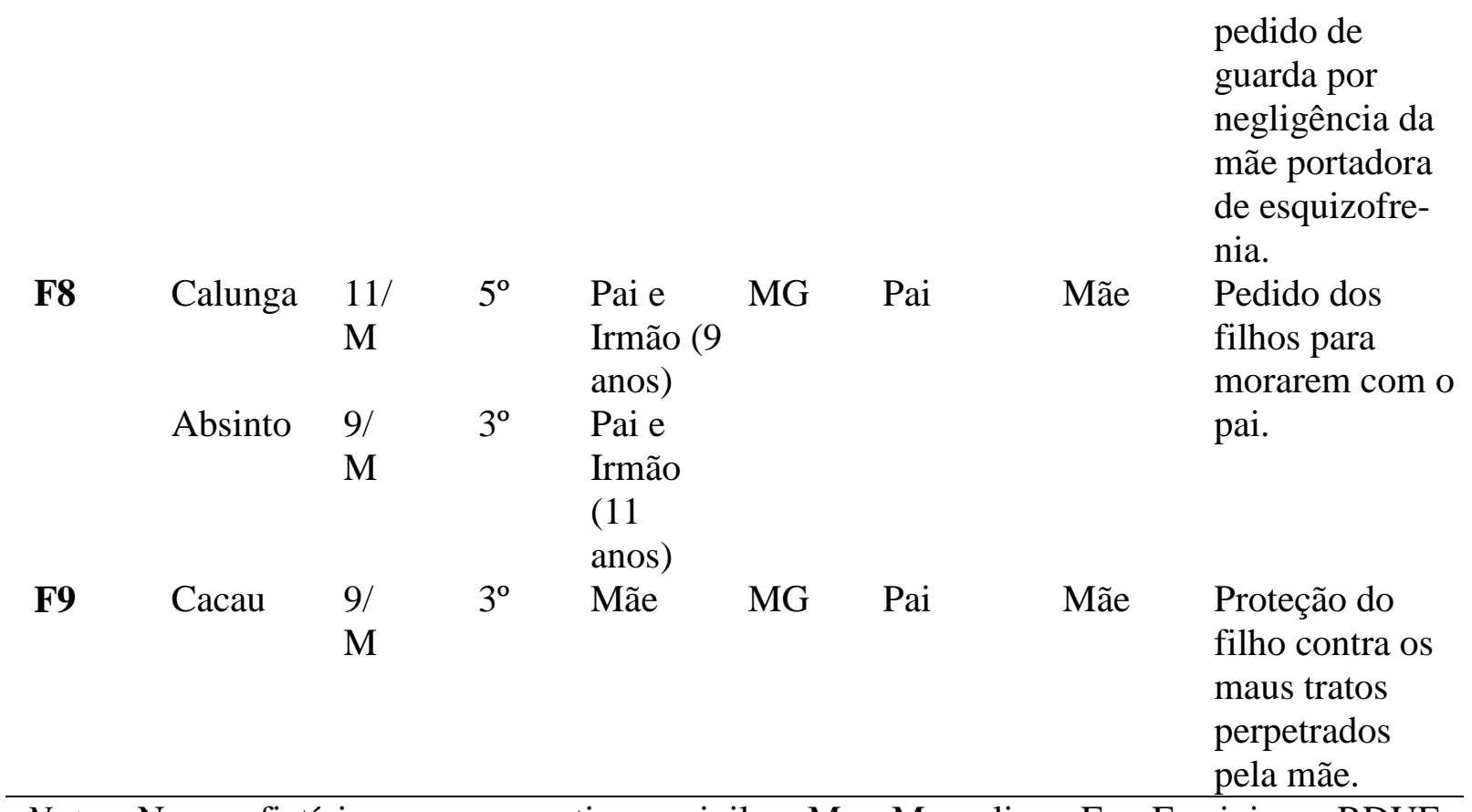

Nota: Nome fictício para garantir o sigilo. $\mathrm{M}=$ Masculino $\mathrm{F}=$ Feminino; $\mathrm{RDUE}=$ Reconhecimento e Dissolução de União Estável; GR= Guarda e Responsabilidade; AG= Acordo de Guarda; RV= Regulamentação de Visita; MG= Modificação de Guarda.

\section{Instrumentos}

Os instrumentos utilizados foram os processos judiciais, as pastas onde são registradas as informações das famílias e os pareceres técnicos efetuados pelos profissionais responsáveis pela avaliação psicossocial. Para se obter as informações com as crianças participantes, utilizou-se um roteiro geral (A) e específico (B), elaborado exclusivamente para esta pesquisa (Apêndice 4). O geral serviu para guiar a interação entre o pesquisador e a criança; e o específico, entrevista semiestruturada, para fornecer subsídios básicos ao desenvolvimento e compreensão das relações entre os participantes e o seu contexto. Para complementar a entrevista, utilizou-se o desenho como instrumento que retrata as expressões da criança conforme propõe Puviani (2011).

\section{Procedimentos}

Primeiramente, esclarecimentos foram efetuados acerca dos objetivos da pesquisa para a supervisora e para os profissionais das equipes do SERAF. Os psicólogos e assistentes sociais se disponibilizaram a contribuir com a pesquisa, favorecendo a observação durante 
todo o tempo do estudo, dispondo-se a discutir o caso tanto ao longo da realização deste quanto durante a redação do parecer técnico. Não houve intercorrências durante a realização dos estudos que prejudicasse a obtenção das informações para a pesquisa, tais como ansiedade e preocupação oriundas dos componentes da família nem dos profissionais responsáveis pela avaliação.

Os profissionais que tinham processos que envolviam crianças com idades que variavam entre 8 e 11 anos informaram as datas e os horários em que aconteceriam os atendimentos. Após a seleção das famílias que se enquadraram nas demandas da pesquisa, realizou-se a leitura dos registros efetuados pelos profissionais nas pastas. Posteriormente, complementou-se as informações por meio da leitura dos processos. Nos casos selecionados, adequou-se às datas e aos horários agendados previamente pelos profissionais do SERAF. No primeiro atendimento, antes de os estudos serem iniciados, foi explicada a presença da pesquisadora que obteria as informações e os objetivos da investigação proposta. Em seguida, leu-se o Termo de Consentimento e os responsáveis pelas crianças, após concordarem, assinaram o documento possibilitando a obtenção das informações para a pesquisa. Esclareceu-se que as referidas informações não influenciariam no andamento processual e não interfeririam na decisão judicial. Esclareceu-se também que a entrevista com a criança ocorreria somente depois que o estudo, realizado pelos profissionais, estivesse encerrado.

$\mathrm{Na}$ entrevista com a criança, explicou-se a pesquisa, na linguagem apropriada para a idade de cada participante, utilizando-se o Termo de Assentimento. O sigilo das informações foi garantido, informando que os nomes seriam alterados e esclarecendo que qualquer dúvida que ainda restasse sobre a pesquisa, os participantes e seus responsáveis poderiam contatar com a entrevistadora pelo número de telefone indicado no referido documento. Assim, somente após o consentimento de todos, procedeu-se à entrevista, sendo que, ao final foi entregue um certificado para a criança (Apêndice 5) em agradecimento pela sua participação 
na presente pesquisa. Todo o trâmite de cada estudo realizado pelos profissionais foi gravado em áudio e, posteriormente, transcrita apenas a entrevista com a criança.

Visando aos ajustes necessários para a organização do material definitivo para a realização da pesquisa, iniciou-se com dois estudos pilotos, que foram efetuados no primeiro de semestre de 2013. Nos estudos pilotos, buscou-se verificar com a criança dois aspectos: sobre sua história vivida até a tramitação processual e sua percepção sobre a disputa de sua guarda na Justiça.

Os resultados desses estudos mostraram que os instrumentos utilizados não favoreceram a obtenção das respostas dos objetivos da pesquisa. Obteve-se a resposta do sofrimento da criança, mas não relacionada à noção do tempo da vivência da criança durante o conflito dos pais nem da percepção do tempo da vivência da criança durante o período da tramitação do seu processo de guarda na Justiça. Com isso, ajustou-se o roteiro de entrevista, a entrevista semiestruturada e o desenho, focando-se no sofrimento da criança.

Para a obtenção das informações desta investigação, após os ajustes dos instrumentos, sete crianças foram entrevistadas individualmente e quatro, na fratria. As informações foram obtidas somente durante a realização do estudo, concomitante ao período em que as ações referentes à disputa de guarda e regulamentação de visita permaneceram no SERAF. Selecionou-se todos os processos que envolveram crianças entre 8 e 11 anos durante os meses de novembro e dezembro de 2013. O principal critério foi incluir famílias que evidenciavam intenso nível de conflito, crônico ou não, na relação familiar, em especial, entre o par parental, tal como descrito por Johnston, Roseby e Kuehnle (2009). As referidas autoras apontam que a transição temporal decorrente da separação conjugal permeada por turbulências na relação, a reorganização da vida do ex-casal e dos filhos é uma das experiências mais desafiadoras e dolorosas que crianças e adultos podem enfrentar levando, em média, de dois a três anos para serem superadas. Ademais, as autoras esclarecem que esse 
tempo pode variar uma vez que existem relacionamentos conflitivos que levam muitos anos para terminar e alguns podem nunca terem os conflitos resolvidos. Desse modo, foram selecionados os processos que continham as características descritas acima, cujas situações foram avaliadas pelos profissionais do SERAF conforme determinação judicial.

$\mathrm{Na}$ entrevista com a criança, utilizou-se um roteiro (Apêndice 4) previamente preparado, que englobou os seguintes aspectos, com ênfase na percepção da criança: o motivo de estar na Justiça, as histórias contadas concernentes as suas percepções e vivências no contexto familiar e as concepções sobre o seu sofrimento. Esse roteiro está dividido em dois momentos: Geral, estabelece o contato inicial com a criança e, Específico, trata da entrevista semiestruturada para fins investigativos. Os itens da entrevista que qualificam a criança estão no Apêndice 3.

O outro instrumento, que serviu para intermediar a obtenção das informações, foi o desenho conforme a proposta de Puviani (2011). Para essa autora, desenhar significa ver e tornar visíveis os mundos interiores e as relações exteriores por meio de geometrias e símbolos, proximidades e distâncias que antes de serem expressos estavam obscuros. Significa, também, ver os problemas e ver as soluções. Oferece-se a folha branca como símbolo do próprio espaço psíquico a ser ocupado com gestos que narram, com linhas que se movem e cores que preenchem. Além disso, o desenho serve para estabelecer a relação entre quem desenha e a pessoa que o acompanha nessa construção e para comunicar emoções. $\mathrm{Na}$ perspectiva proposta pela autora, o desenho é autorrevelação, havendo integração entre o verbal e o não verbal.

O desenho pode ser examinado sob variados pontos de vista: evolutivo, projetivo, narrativo, artístico, dentre outros, sendo que na presente investigação, o desenho foi analisado pela ótica da expressão. Desse modo, por meio do desenho a criança revela seus estados de ânimo, aponta os conflitos familiares, faz solicitações e fornece respostas, possibilitando 
direcionar as intervenções para transformar as histórias de vida (Andolfi, 2013; Puviani, 2011).

Para compreender os desenhos é necessário estudá-los. No caso de desenhos infantis (haja vista serem as crianças os participantes desta pesquisa) deve-se observar o que estes comunicam: problemas, descobertas, ansiedades. Pode-se considerar o desenho sob dois significados: formador e revelador de personalidade (Puviani, 2011). Para tanto, essa autora esclarece ser necessário que o desenho seja colocado, reconhecido e interpretado em local apropriado, no caso de contexto clínico, de onde se origina esse enfoque, o setting terapêutico. No âmbito desta pesquisa, contudo, o contexto é o da Psicologia aplicada à esfera judicial e, para tanto, utilizou-se as salas onde está situado o trabalho do SERAF, conforme explicitado no item que trata do contexto na pesquisa.

Desse modo, mediante solicitação da pesquisadora que conduziu a entrevista individual, focou-se no problema e na solução (Puviani, 2011) que foram utilizados como consignas para a realização dos desenhos pelas crianças participantes da investigação. Com isso, a criança poderia representar suas vivências referentes ao conflito familiar que envolve a ação judicial. Assim, ofereceu-se uma folha em branco e pediu-se que a criança desenhasse as suas preocupações, tristezas ou sofrimentos. Posteriormente, ofereceu-se outra folha de papel em branco e solicitou-se que ela fizesse outro desenho, representando as soluções em relação às preocupações, tristezas ou sofrimentos apontados. A execução do desenho, tanto em relação às preocupações quanto às soluções, poderia requerer, por parte da criança, mais de uma folha de papel em branco e, quando solicitado, ofereceu-se a quantidade de papel que ela necessitasse naquele momento. Ofereceu-se, também lápis preto n. 2 e coloridos. Na consigna para a confecção do desenho, sugeriu-se que fosse feito de duas maneiras. Uma delas seria representar as imagens que lhe viesse à mente e, a outra, que a criança se inspirasse nos elementos que compõem a natureza, a partir dos reinos mineral, vegetal e animal. Considerou- 
se que a inspiração na natureza poderia ampliar suas ideias, permitindo a livre expressão de sua criatividade, tal como apontado por Puviani (2011).

\section{Cuidados Éticos}

A pesquisa teve início somente após a aprovação do projeto que foi submetido ao Comitê de Ética em Pesquisa conforme resolução do CFP 016/2000 (Anexo 1). Essa aprovação incluiu o termo de compromisso assinado pela Secretária da Secretaria Psicossocial Judiciária (Anexo 2), à qual hierarquicamente o SERAF está vinculado. Houve o provimento de Termos de Consentimento Livre e Esclarecido (TCLE) para o responsável pela(s) criança(s) assinar (Apêndice 1) e o Termo de Assentimento (Apêndice 2) na forma oral.

\section{Análise das informações}

Após a obtenção das informações, efetuaram-se as transcrições das entrevistas realizadas com a criança que tiveram os conteúdos analisados na modalidade de análise temática (Minayo, 2014). A análise de conteúdo, conforme aponta essa autora, é mais comumente usada na representação das informações obtidas em pesquisa qualitativa. É considerado um procedimento técnico que envolve teoria e prática no campo das pesquisas sociais. Nessa perspectiva, as técnicas de investigação favorecem a replicação e validação das inferências sobre os dados de um determinado contexto. Embora a análise de conteúdo tenha se originado de pesquisas quantitativas, houve interesse em identificar, nos textos escritos nos meios de comunicação à época da Segunda Guerra Mundial se havia tom subversivo nazista levando os estudiosos a analisarem os símbolos impressos em jornais e periódicos implicados.

Com a inclusão da Sociologia, Antropologia e Psicologia ao Jornalismo, surgem duas concepções de comunicação: o modelo instrumental, em que o mais importante é o que é expresso no contexto e nas circunstâncias em que ocorre, e o modelo representacional, focalizando a quantidade e o sentido das palavras (conteúdo léxico). Embora originalmente 
nesse tipo de análise haja preocupação com frequência das falas e das palavras, buscou-se, na presente pesquisa, tal como aponta Minayo (2014), atingir, por meio da inferência, interpretar de modo mais profundo as falas das crianças participantes, sem levar em conta a referida frequência das palavras. Desse modo, a análise de conteúdo inicia-se das falas, depoimentos e documentos direcionando-se ao nível mais aprofundado, ultrapassando o que está manifesto. A análise de conteúdo está na articulação entre as estruturas semânticas (significantes) com as estruturas sociológicas (significados) do que está expresso nas verbalizações buscando as características que incluam as variáveis psicossociais, contexto cultural e processo de produção da mensagem. Com isso, o processo analítico favorece a replicação dos procedimentos por outros investigadores para a obtenção dos mesmos resultados.

Minayo (2014) esclarece que após a leitura exaustiva das falas transcritas, os temas (feixe de relações a respeito de determinado assunto) apontam os núcleos de sentido, imbuídos de significado para a análise da investigação. De acordo com essa autora, são três etapas: a primeira envolve a pré-análise, que engloba a leitura flutuante das comunicações, visando à impregnação do conteúdo. Depois, a constituição do corpus para validação qualitativa, que engloba: exaustividade, representatividade, homogeneidade e pertinência. A segunda, exploração do material, visa alcançar o núcleo de compreensão do texto, identificando expressões ou palavras significativas para o conteúdo que se busca. A terceira e última etapa, refere-se ao tratamento dos resultados obtidos e interpretação. Com os resultados brutos obtidos, faz-se inferências e interpretações articulando-as com a fundamentação teórica, produzindo assim, novos conhecimentos.

Assim, na presente investigação, primeiramente foram lidas todas as entrevistas. Após várias releituras perceberam-se nove núcleos temáticos que se sobressaíram: 1. Sentimentos que expressam o sofrimento, 2. Origem do sofrimento, 3. A superação do sofrimento; 4. Como a criança se sente em relação aos componentes da família; 5. Como a criança se sente 
em relação a ter que escolher entre pai ou mãe; 6. Intervenções/ações/estratégias empreendidas por ela para sobreviver no conflito parental/familiar; 7. A Justiça é que decide; 8. O juiz é quem decide; e 9. Processo de reflexão. Depois de se constituir os núcleos temáticos, formaram-se três grupos: o primeiro referiu-se ao sofrimento da criança: expressão, origem e superação; o segundo tratou dos sentimentos em relação aos componentes da família, dos sentimentos em relação a ter que escolher entre pai ou mãe e das ações da criança para sobreviver ao conflito; e o terceiro versou sobre a expressão da criança em sua participação no contexto de decisão: a Justiça decide, o juiz decide e o processo de reflexão. Os desenhos das crianças participantes desta pesquisa (Anexos 3 a 34C) fizeram parte dos os núcleos temáticos constituídos e foram agregados no estabelecimento dos referidos núcleos.

\section{Importância do Estudo}

A importância deste trabalho reside no fato de cooperar com avanços na pesquisa no campo da Psicologia Jurídica e no reconhecimento da capacidade da criança em participar, argumentar, refletir e decidir sobre os assuntos que lhe diz respeito (Birnbaum \& Saini, 2012; Costa \& Miragem, 2012), contribuindo para o desenvolvimento de sua autonomia (Costa et al, 2009) no contexto de separação/divórcio parental. Contemplar a ótica da criança nesse âmbito torna as decisões na instância judicial mais adequadas as suas reais necessidades e assegura a prática dos seus direitos fundamentais (Santa Rosa, Almeida, \& Corte Real, 2014), ao invés de se valorizar o conflito destacado pelos pais ou por seus representantes legais (Santos, 2014). Com isso, esta tese, com base em informações empíricas, identificou caminhos expressos pela criança para enfrentar o sofrimento durante a disputa parental quando participa da avaliação psicossocial. 


\section{Estrutura da Tese}

A apresentação desta tese foi feita conforme novo modelo adotado pelo Programa de Psicologia Clínica e Cultura em que os capítulos foram redigidos em formato de artigos. Isso se constituiu em desafio para a execução da presente proposta. Assim, a tese foi estruturada da seguinte forma: introdução, em que se efetuou a apresentação geral do trabalho. Posteriormente, foram incluídos os artigos que objetivam serem publicados em revistas científicas. O primeiro artigo teórico refere-se a um levantamento de estudos que tratam da voz da criança quando vivencia a disputa de guarda, nos âmbitos nacional e internacional, considerando-se protocolos que contribuam para avaliação. O segundo artigo teórico aborda o sofrimento da criança durante a disputa de guarda no qual se fez uma revisão da literatura para conhecer-se estudos atualizados sobre o tema. Em seguida, vem o único artigo empírico resultante do estudo piloto que trata das estratégias de enfrentamento da criança no decorrer do conflito familiar, observado durante a avaliação psicossocial, dando ênfase à fratria no enfrentamento das dificuldades vivenciadas. Logo após, insere-se o primeiro artigo empírico da pesquisa sobre o sofrimento da criança em disputas de guarda. Detectaram-se os sentimentos expressos pelas crianças participantes, observando-se as soluções apontadas por elas na garantia do atendimento de suas necessidades. Posteriormente, inclui-se o segundo artigo empírico em relação às estratégias de sobrevivência da criança aos conflitos familiares em disputas de guarda. O terceiro e último artigo empírico, resultado da pesquisa, refere-se à expressão da criança em ações de disputa de guarda, indicando que a decisão judicial poderá ser mais assertiva em relação ao que importa no atendimento aos interesses dela. Ao final, estão descritas as considerações finais da tese que, tal como a introdução, não serão publicadas. As referências citadas em todos os capítulos foram relacionadas após as considerações finais da tese e estão em uma única sequência, evitando-se repetição de autores em cada artigo apresentado. Entretanto, em cada artigo que contém esta tese, os autores foram citados sem considerar o fato de terem sido mencionados desde a introdução deste trabalho, 
pois os referidos artigos foram encaminhados às revistas em formato independente. Com relação ao método da pesquisa, está descrito nos três capítulos empíricos da tese com poucas alterações de conteúdo, variando apenas no enfoque apontado em cada artigo.

Esclareça-se que os artigos Estratégias de Enfrentamento dos Filhos ao Conflito Conjugal no Contexto da Justiça e Da Invisibilidade à Participação: A Expressão da Criança em Disputas de Guarda estão em processo de submissão em revistas que utilizam revisão de pares conforme indicado na nota de rodapé descrita no início desses capítulos. O artigo teórico O Sofrimento da Criança na Vivência da Disputa de Guarda no Contexto da Justiça foi publicado na Revista Portuguesa de Pedagogia da Faculdade de Psicologia e Educação da Universidade de Coimbra e está disponível no link: http://impactumjournals.uc.pt/index.php/rppedagogia/issue/archive 


\title{
ARTIGO TEÓRICO 1 \\ Voz da Criança na Avaliação Psicossocial em Disputas de Guarda
}

Marcia Regina Ribeiro dos Santos

\section{Resumo}

Neste artigo, refletiu-se sobre a importância de escutar as narrativas da criança em relação à maneira como ela vive, sente e pensa face ao conflito presente na disputa parental concernente a sua guarda, no decorrer da avaliação psicossocial. No Brasil, os estudos sobre avaliação da criança revelam a necessidade de se realizar mais pesquisas para melhor conhecimento dessa prática. A esfera internacional, inclui entrevistas com as crianças para obter informações relevantes sobre as suas emoções, e os significados que ela atribui às experiências vividas no decorrer da separação/divórcio de seus pais. Visando ao aperfeiçoamento do trabalho dos profissionais que ouvem a criança, apresentam-se sugestões de instrumentos e modelo de protocolo de avaliação, contribuindo para que as decisões tomadas na instância judicial sejam mais condizentes com as reais necessidades dela.

Palavras-chaves: Avaliação psicossocial; narrativas da criança; disputas de guarda parental

\section{Voice of the child in psychosocial assessments in child custody disputes}

\author{
Abstract \\ This article discusses the importance of listening to the children's narratives, regarding the \\ way they live, feel and think in face of their parents' present dispute over their custody, \\ throughout the psychosocial assessment. In Brazil, studies on child assessment reveal a need \\ for more research in order to improve the knowledge of this practice. Abroad, interviews with \\ the children are included to obtain relevant information about their emotions and the
}


meanings they attribute to the experiences they go through during the separation or divorce of their parents. Aiming at improving the work of professionals that listen to such children, suggestions of tools and an assessment protocol model are presented, thus helping decisions made in court to be more consistent with the actual needs of the children.

Keywords: Psychosocial assessment; children's narratives; parental custody disputes

\section{Voz de los niños en la evaluación psicosocial en disputas de guarda}

\section{Resumen}

En este artículo, se reflexiona sobre la importancia de escuchar las narrativas da los niños, en relación a la manera como ellos viven, sienten y piensan en vista del conflicto presente en la disputa parental concerniente a su guarda, en el transcurso de la evaluación psicosocial. En Brasil, los estudios sobre evaluación de los niños revelan la necesidad de que más pesquisas se realicen para un mejor conocimiento de esta práctica. En el ámbito internacional, incluí entrevistas con los niños para obtener informaciones relevantes sobre sus emociones y los significados que ellos atribuyen a las experiencias vividas en el transcurso de la separación/divorcio de sus padres. Pretendiendo el perfeccionamiento del trabajo de los profesionales que escuchan a los niños, se presentan sugerencias de instrumentos y modelo de protocolo de evaluación, contribuyendo para que las decisiones tomadas en la instancia judicial sean más condecentes con las reales necesidades suyas.

Palabras-clave: Evaluación psicosocial; narrativas de niños; disputas de guarda parental

Apesar de o Estatuto da Criança e do Adolescente (ECA) estabelecer distinção entre criança, até 12 anos, e adolescente, entre 12 e 18 anos, adotou-se como referência, ao longo do presente artigo, o estabelecido no Art. $1^{\text {o }}$ na Convenção sobre os Direitos da Criança (UNICEF, 1990) em relação à palavra criança, que se refere a todo o ser humano menor de 18 
anos. Os textos disponíveis indicam que a vivência da separação/divórcio é um processo singular, sendo que cada criança vive a separação dos seus pais de modo diferenciado. Devem-se considerar as características individuais, a etapa do desenvolvimento de cada componente da família, as inter-relações familiares atentando-se para o ciclo de vida da família, além dos fatores econômico, social, cultural e religioso (Cano, Gabarra, Moré, \& Crepaldi, 2009). Assim, a escassez do material produzido nessa área e o crescente aumento de separações/divórcios (Juras \& Costa, 2011a) que exige dos profissionais conhecimento aprofundado e especializado nesse assunto, motivou a elaboração do presente texto.

O princípio do melhor interesse da criança é constitucional e infraconstitucional (Constituição Federal de 1988, Art. 227, caput, e Estatuto da Criança e do Adolescente, arts. $4^{\circ}$, caput, e $5^{\circ}$ ) e objetiva nortear a ação das instituições públicas em atender aos direitos da criança dependente de adultos responsáveis para auxiliá-la a desenvolver-se. Esse princípio deve ser incorporado e cumprido pela família, pela sociedade e pelo Estado. Isso, porém, não significa o atendimento restrito aos desejos da criança, mas visa a garantir os seus direitos. $\mathrm{O}$ melhor interesse da criança vincula-se "ao estabelecimento de limites, à disposição para receber educação, ao respeito à autoridade dos pais e professores, ao conhecimento de noções de responsabilidade e ao respeito às regras sociais" (Kreuz, 2012, p. 73).

Aliar a legislação brasileira, baseada no referido princípio, às abordagens científicas das diferentes áreas das ciências humanas e sociais é um processo que instiga a busca contínua de respostas dos profissionais atuantes no âmbito de Varas de Família e provoca novas e incessantes indagações (Pessina \& Mendes, 2012; Santos \& Costa, 2010). Ademais, a rápida expansão e articulação do trabalho entre as ciências sociais e a Justiça evidencia deficiências dos estudos no meio acadêmico, dificuldade de encontrar publicações na área e despreparo dos profissionais, exigindo o desenvolvimento de pesquisas científicas que favoreçam a ampliação e a disseminação do conhecimento nessa área (Cano et al, 2009; Lago 
\& Bandeira, 2008; Lago, Amato, Teixeira, Rovinski, \& Bandeira, 2009). Desse modo, concernente à interface entre a Psicologia e o Direito de Família, considera-se importante a atualização dos profissionais no trabalho de avaliação em situações de disputa de guarda, considerando as diferentes configurações familiares e o modo como as relações, em especial entre pais e filhos, estão sendo construídas (Barbosa \& Castro, 2013; Costa, Penso, Legnani, \& Sudbrack, 2009; Lago \& Bandeira, 2009).

A dimensão psicossocial torna-se aspecto significativo quando se trata de avaliação da criança no âmbito judicial de guarda (Costa et al., 2009). Embora o United Nation High Commissioner for Refugees (UNHCR, 2008) refira-se a aspectos relativos a famílias refugiadas, considerou-se apropriado mencionar neste artigo, tal como lá descrito, que a avaliação do melhor interesse da criança deve ser feita por um ou mais profissionais desde que tenha(m) os conhecimentos necessários para as providências concernentes às peculiaridades das famílias litigantes. Assim, a realização do trabalho psicossocial, nesse âmbito, amplia o olhar para a complexidade que se apresenta nas famílias que são litigantes na disputa de guarda, contribuindo para que a criança seja vista como sujeito ativo no processo judicial (Pessina \& Mendes 2012; Ribeiro, 2010).

Pensando na complexidade que envolve o melhor interesse da criança, ao ampliar o olhar sobre o litígio familiar durante o processo de definição de guarda na Justiça propõe-se, neste artigo, refletir sobre a importância de considerar as narrativas das crianças relativamente as suas vivências, expectativas e sentimentos sobre a sua família que envolve o processo de separação dos seus pais, na avaliação realizada em contexto de disputa judicial, visto que se encontra enredada em tomadas de decisões a ela referentes, que vão provocar alterações em sua rotina e em sua rede de apoio pessoal e social. Com isso, acredita-se que a criança se sentirá acolhida e amparada em seus anseios, evitando-se colocar sobre ela a responsabilidade de uma decisão que não lhe cabe, porém reconhecendo seu lugar como sujeito de direitos 
nesse contexto. Sugestões são apresentadas concernentes aos instrumentos utilizados nessa avaliação, que possibilitem aos profissionais atuantes no campo da Justiça de família, o aperfeiçoamento do trabalho que realizam ao ouvirem a criança em momento tão singular para ela. Esta proposta visa, assim, contribuir para enriquecer o trabalho dos profissionais nessa área da avaliação de criança no contexto de disputa de guarda, considerando os instrumentos apresentados e modelos de protocolo de avaliação centrados na voz da criança.

\section{A Avaliação de Guarda no Brasil}

Os parâmetros apresentados pelo Conselho Federal de Psicologia (CFP, 2010) chamam a atenção para o fato de se compreender o papel da criança, durante o processo de avaliação da disputa de guarda, quando de sua participação nesse âmbito. O psicólogo deve, ao ouvi-la atenta e cuidadosamente, considerar que a expressão de sua vivência pode apontar novos significados para a família e direcionar a lógica do conflito para atender o seu bemestar e a seu saudável desenvolvimento. Ferreira (2008) argumenta que a atuação da criança nesse processo não envolve apenas o acatamento integral da vontade da criança, não sendo este o caminho mais adequado para atender ao seu melhor interesse. A autora argumenta que a criança, por depender do outro, tem a sua voz permeada por motivações e efeitos da dialética familiar, ambiente em que se insere. Nessa perspectiva, Cardoso e Costa (2014), de modo mais contundente, observam ser importante ouvir a opinião e sugestões da criança que vivencia a separação dos pais, além de sua percepção do contexto da guarda. Concluem, porém, que a decisão sobre a quem se deve destinar a sua guarda não pode ser incumbência do infante.

Em um levantamento das práticas das avaliações utilizadas pelos psicólogos no Brasil, Lago (2008) e Lago e Bandeira (2008) verificam haver escassez de estudos na área de avaliação psicológica em contexto de disputa de guarda. Além disso, observam que os 
profissionais, ao realizarem a avaliação, não têm uma padronização de instrumentais nessa prática. Segundo as pesquisadoras, isso se deve à complexidade dos casos e à peculiaridade que cada um apresenta. Quanto à avaliação psicológica de criança no âmbito da Justiça de família, as referidas pesquisadoras depreendem ser a entrevista o principal instrumento utilizado pelos psicólogos. A diferença está no modo como os profissionais organizam essa entrevista, ou seja, com os pais e filhos separadamente ou em conjunto.

Lago (2008) e Lago e Bandeira (2008) verificam, também que, para a avaliação não se restringir a informações apenas da criança e de seus pais, os psicólogos incluem entrevista com os avós, babás, vizinhos, com os professores da escola em que a criança estuda. Como complemento da entrevista, há profissionais que recorrem a testes psicológicos. Os testes projetivos mais utilizados com crianças e adolescentes: House, Tree, Person (HTP), Desenho da Figura Humana e Teste das Fábulas e, com os pais, também projetivos, incluem-se, além do HTP, o Teste de Apercepção Temática (TAT) e Rorschach. Na sequência desse estudo e diante das novas configurações familiares, Lago, Amaral, Bosa e Bandeira (2010) apresentam os principais instrumentos que identificaram a partir de uma revisão sistemática em que foram analisados os tipos de relações entre pais e filhos. Concluem que o material brasileiro disponível é escasso, defendendo a necessidade de estudos que adaptem ou construam instrumentos nesse contexto.

\section{Avaliação de Guarda na Esfera Internacional}

No âmbito internacional, Symons (2010) faz uma revisão da teoria aliada à prática dos profissionais sobre a avaliação de guarda e visita nos Estados Unidos e Canadá. Para esse autor, o processo de avaliação efetuado pelos psicólogos nesses países envolve conhecimento nas habilidades parentais em acolher e proteger a criança privilegiando-se a análise da dinâmica, organização e suporte emocional observados no meio ambiente oferecido pelo pai 
e/ou pela mãe concernentes aos cuidados destinados à criança. No entanto, de acordo com Symons (2010), embora a finalidade precípua da avaliação seja identificar as necessidades da criança, o referido processo avaliativo não apresenta aspectos que evidenciem a livre expressão da criança no sentido de espaço de escuta, acerca dos assuntos referentes a ela na Justiça de família. Isso denota a necessidade de novas pesquisas que contemplem o ponto de vista da criança como parte da análise apresentada pela compreensão da dinâmica familiar expressa pelos pais e familiares.

Saywitz, Camparo, e Romanoff (2010), ao analisarem a pesquisa desenvolvida na Irlanda, Noruega, Austrália e Nova Zelândia, corroboram a escassez de dados científicos referentes aos efeitos da preferência das crianças no ajuste pós-separação/divórcio. Para essas autoras, há a necessidade de entender os efeitos negativos e positivos da participação ou não da criança nos diferentes processos judiciais, bem como das preferências expressas por elas referentes ao seu bem-estar. Além disso, ressaltam que as crianças não querem decidir com quem deverão residir, mas participar do processo de decisão, pronunciar-se sobre questões que a elas dizem respeito. Com base nas pesquisas encontradas, as autoras verificam que os protocolos existentes foram gerados em situações nas quais as crianças eram testemunhas ou vítimas de crimes. Como conclusão da pesquisa, Saywitz et al, 2010) apresentam um conjunto de 10 princípios para a prática de entrevista com crianças, especificamente: 1 .Fornecer um ambiente privado apropriado para a idade da criança com o mínimo de distrações; 2. Preparar a criança dando explicações adequadas a sua idade sobre a finalidade da entrevista, papel dela naquele contexto e as funções dos profissionais; 3. Criar, de modo imparcial, uma atmosfera de não-julgamento para que as percepções da criança sejam exploradas com interesse e respeito; 4. Esforçar-se para estabelecer rapport evitando pressionar a criança a qualquer tipo de resposta; 5. Promover uma atmosfera acolhedora, não-ameaçadora e de apoio; 6. Adequar as demandas da entrevista de acordo com a faixa etária da criança, com linguagem que deverá 
ser ajustada para que ela compreenda os conceitos que estão sendo tratados; 7. Estabelecer regras básicas de conversação e compartilhar expectativas com narrativas e instruções simples; 8 . Envolver a criança em conversa sobre uma ampla gama de temas pertinentes ao processo de tomada de decisão como, por exemplo, analisar as vantagens e desvantagens de diferentes opções, em vez de condensar a tarefa a uma pergunta sobre onde a criança prefere morar; 9. Colocar questões abertas e gerais que possibilitem pluralidade de palavras nas respostas, sempre que possível, e convidar a criança a elaborar suas próprias respostas, com frases explicativas e não apenas "sim”, "não", "não sei”; e 10. Evitar técnicas sugestivas que induzam a criança a dar informação errada, introduzam vieses ou reforcem as expectativas do entrevistador.

Os pesquisadores canadenses Birnbaum e Saini (2012) referem que muito tem sido publicado nas duas últimas décadas sobre a importância da voz da criança e do adolescente em contexto de disputa de guarda. Esses autores identificam uma posição dicotômica entre considerar ou não a voz da criança na tomada de decisão acerca da guarda e visitação do pai não guardião. Todavia, os estudos demonstram a necessidade de assegurar que os pontos de vista da criança sejam autenticamente incluídos nos assuntos da família. As investigações apontam, também, pontos de vista diversificados a partir da voz das crianças: enquanto algumas esperam decidir, outras preferem apenas partilhar as suas opiniões e preferências; outras optam por manifestar-se quanto aos desajustes no processo de separação versus resiliência e adaptação à dinâmica da organização familiar; outras, ainda, precisam de uma casa como referência, diferentemente daquelas que realçam a manutenção do relacionamento com ambos os pais. Birnbaum e Saini concluem que os profissionais devem considerar a voz da criança na tomada de decisão e não apenas acatar a vontade verbalizada por ela na crença de estar atendendo ao seu melhor interesse. Acrescentam serem necessárias pesquisas de 
follow up para saber o que funciona e o que não parece ser eficiente no trabalho com crianças para ajudá-las a superar esta situação de crise.

Com relação às pesquisas desenvolvidas na Holanda, van Nijnatten e Jongen (2011) realçam a importância da participação da criança e os efeitos das descobertas de suas ideias e sentimentos sobre os eventos que ocorrem em suas famílias. A conversa com a criança deve envolver as organizações pós-divórcio, evitando-se considerá-la como vítima dos desentendimentos entre os pais depois da separação. Para estes autores, é importante que o profissional atente aos sentimentos e pensamentos íntimos da criança, estabelecendo uma atmosfera de confiança para abordar as discussões relativas à organização familiar pósdivórcio.

van Nijnatten e Jongen (2011) esclarecem que o profissional deve planejar a conversa que terá com a criança de modo a prepará-la para entender o contexto em que se encontra, possibilitando que a conversação seja individual para facilitar a partilha dos seus sentimentos e das suas difíceis vivências. Os instrumentos utilizados para facilitar a comunicação são jogos e brinquedos apropriados para a faixa etária da criança, pois, assim como acontece com os adultos, elas também podem demonstrar dificuldade em expressar o que sentem, pensam e esperam do processo.

Ainda no âmbito internacional os estudos desenvolvidos na Austrália por Cashmore (2011), Cashmore e Parkinson (2008) e Cashmore e Parkinson (2009) mostram que as crianças querem participar opinando sobre as suas escolhas em relação a morar com o pai ou com a mãe e, também, quanto à periodicidade da visitação. Estes autores verificam que, enquanto os pais se preocupam com o risco de manipulação e pressão do ex-cônjuge sobre a criança no processo de tomada de decisão, para as crianças o mais importante é a igualdade de condições em ambos os núcleos familiares concernentes à proteção, segurança e cuidados. Além disso, essas investigações assinalam que o envolvimento das crianças no processo de 
tomada de decisão é essencial, mas não deve ser determinante. Para os referidos pesquisadores, o profissional deve ter sensibilidade e consciência dos tipos de decisões que cabem à criança, podendo minimizar a tensão entre participação e proteção. Ademais, concluem que, conduzir com seriedade o ponto de vista das crianças, indica respeito e confiança, reconhecendo-as como pessoas com necessidades, mas com dignidade, individualidade e como agentes ativos nas tomadas de decisões a elas relativas.

Em Portugal, conforme descreve Pereira e Matos (2008), é importante que o processo de avaliação em contexto de regulação das responsabilidades parentais seja multifacetado a fim de medir o impacto do divórcio e do litígio familiar, priorizando a criança e ambos os pais, buscando-se informações com terceiros, nomeadamente avós e professores. Para tanto, são utilizadas técnicas de entrevista e testes de avaliação psicológica como complemento. Com os pais, por meio de entrevista deve-se explorar a história e a dinâmica familiar, assim como permitir a recolha de informação relativa à percepção do bem-estar e necessidades dos filhos. Recorre-se, também, a instrumentos de avaliação psicométrica com os pais relativamente ao exercício da parentalidade, particularmente no que respeita aos padrões de vínculo, de comunicação e das práticas educativas parentais (Pereira \& Matos, 2008; Portugal \& Alberto, 2014).

Com a criança, são utilizados recursos de caráter lúdico, como desenho e fantoches, de acordo com a sua faixa etária. O objetivo é o estabelecimento de rapport entre a criança e o profissional para possibilitar que ela sinta confiança em se pronunciar sobre a forma como percebe e se sente perante a separação dos pais. Além disso, os profissionais utilizam testes psicológicos para melhor compreenderem a criança relativamente ao seu funcionamento psicológico, eventual sintomatologia e percepção que tem sobre a relação com os seus pais. Os profissionais recorrem ainda à observação da criança em situação natural, como por exemplo, na sala de espera, enquanto aguarda atendimento (Pereira \& Matos, 2008). O 
destaque é dado para a interação entre os pais e a criança no sentido de identificar a qualidade da relação com ambos os pais, observando com quem tem mais afinidade; se há preferência da criança para com um dos pais, ou se manifesta sentimento de ambivalência ou rejeição sobre algum deles ou ambos. Deve-se apurar, ainda, no decorrer da avaliação, se a criança está triangulada no conflito conjugal ou se ela tem, em relação a um dos pais uma postura de passividade e retraimento perante situações de conflito (Agulhas \& Anciães, 2014).

Em síntese, a literatura evidencia olhares diferenciados para ouvir a voz da criança no contexto de disputa de guarda, alternando-se entre o atendimento de suas necessidades para a sua proteção e a busca de conhecimento do interesse dela para garantia dos seus direitos nas questões em que lhes dizem respeito (Pereira \& Matos, 2008).

\section{A criança como Foco nas Diretrizes que Norteiam o Trabalho de Avaliação}

O Conselho Federal de Psicologia (CFP) ao delinear o trabalho do psicólogo que atua na esfera judicial, considera a criança no contexto sociofamiliar em que se insere e pontua os seguintes aspectos:

Observa-se que, quando há denúncias de que direitos de crianças ou de adolescentes estão sendo violados, o atendimento psicológico no contexto jurídico inclui a escuta de familiares da criança e/ou das pessoas de referência desta, para que o caso possa ser compreendido em sua dimensão sociofamiliar. Não se deve desconsiderar que o atendimento psicológico nessa esfera pressupõe leitura cuidadosa das relações familiares, entendendo-se a criança como membro desse sistema familiar (CFP, 2010, p.21).

A Convenção sobre os Direitos da Criança (UNICEF, 1990) especifica a importância de se garantir sua livre expressão, conforme o artigo 12, abaixo descrito. Os Estados-Partes (o Brasil é um deles), 
(...) garantem à criança com capacidade de discernimento o direito de exprimir livremente a sua opinião sobre as questões que lhe respeitem, sendo devidamente tomadas em consideração as opiniões da criança, de acordo com a sua idade e maturidade. Para este fim, é assegurada à criança a oportunidade de ser ouvida nos processos judiciais e administrativos que lhe respeitem, seja diretamente, seja através de representante ou de organismo adequado, segundo as modalidades previstas pelas regras de processo da legislação nacional (Convenção sobre os Direitos da Criança, UNICEF, 1990, p. 10).

A referida Convenção destaca que todas as decisões referentes à criança, oriundas de entidades públicas ou privadas que tratem da proteção social e jurídica, deverão considerar o melhor interesse da criança. Esse princípio se tornou ponto fundamental para que as nações buscassem meios para observarem o atendimento das necessidades da criança. No Brasil, a Constituição Federal, promulgada em 1988; a Lei no 10.406 de 10 de janeiro de 2002, referente ao Código Civil; e a Lei no 8.069 de 13 de julho de 1990, relativa ao Estatuto da Criança e do Adolescente (ECA) normatizam a garantia do atendimento ao melhor interesse da criança.

Percebe-se, portanto, com base na Convenção sobre os Direitos da Criança (UNICEF, 1990) e nas Referências Técnicas para Atuação do Psicólogo em Varas de Família (CFP, 2010), que cabe ao profissional utilizar-se dos recursos técnico-científicos disponíveis para garantir os direitos da criança, resguardando seus interesses precípuos a fim de favorecer sua expressão a respeito de questões que estão diretamente a ela vinculadas. A análise do artigo $3^{\circ}$ dessa Convenção será tratada mais adiante neste texto.

Conforme aponta Lee (2010), a legislação, ao referir-se à criança, apresenta aspectos que se tornam polêmicos. Segundo esse autor, por exemplo, no tocante ao Artigo 12 da 
Convenção sobre os Direitos da Criança (UNICEF, 1990), ele o considera ambíguo, o que pode contribuir para dificultar a compreensão referente à voz da criança. Para ele, a redação do artigo permite entender que a criança é considerada igual ao adulto por ser vista como ser humano que deve seguir normas e valores de certo e errado impostos pela sociedade, e, menor e inferior para ter sua voz considerada. O citado autor entende haver diferentes "práticas de voz" que vão além de processos formais e informais, em casos de adoção e guarda, em situações de divórcio nas quais a criança está diretamente afetada. Na prática, ou as crianças ficam fora da formalidade nas tomadas de decisões por incapacidade de funcionar fora da informalidade, ou o processo de decisão deve fazer-se mais informal. Assim, examinar essa diversidade poderá ampliar a capacidade de vislumbrar mudanças nessa área.

Com relação ainda ao artigo 12 da Convenção, Saywitz et al. (2010) consideram que, nos casos de disputa de guarda, a preocupação está em conciliar a obrigação do Estado em atender ao melhor interesse da criança com o direito dela expressar suas opiniões, as quais têm importância no processo. Segundo essas autoras, vários pesquisadores acreditam que as crianças têm o direito de participar e devem ter o direito à palavra ao invés de serem excluídas do processo de decisão. O profissional, ao valorizar as narrativas da criança, não deve desconsiderar a família e o meio ambiente em que ela está inserida, mas permitir que ela participe, argumente, reflita e decida em conjunto, deixando de ser invisível (Costa \& Miragem, 2012). Portanto, a criança precisa ser ouvida não apenas em relação ao conteúdo da sua fala, mas no significado de sua expressão nesse contexto de decisão, pois o seu desenvolvimento inclui a ascensão da sua autonomia na articulação entre o seu mundo interno e externo (Costa et al., 2009).

Nesse sentido, Costa e Miragem (2012) salientam que ouvir o que a criança tem a dizer significa reconhecê-la como pessoa, cidadã com competência. Os autores consideram que a criança, ao longo de seu desenvolvimento deve ter espaço para expressar o que precisa e 
o que pode fazer por si. Os pesquisadores afirmam que o contexto social e o grau de suporte fornecido pelo adulto influenciarão na capacidade de a criança, mesmo as mais novas, entender as questões que a afetam. Para os referidos pesquisadores, a participação da criança requer espaço para a "escuta atenta" do conteúdo dos processos que envolvem tomadas de decisão. Cabe, então, ao Estado, às instituições e aos adultos responsáveis por ela, providenciarem o atendimento aos seus interesses e a garantia de seus direitos. De acordo com Costa e Miragem, o adulto deverá proporcionar à criança, "as informações e o suporte necessários a fim de contribuir na autonomia e fomentar o desenvolvimento das habilidades e competências na tarefa" (p. 688) de permitir que ela expresse seus interesses.

No campo dos estudos da infância, James (2006) destaca que se deve distinguir a "infância" como espaço social, "crianças" como categoria geracional e "criança" como indivíduo representante da categoria e como habitante desse espaço. Então, pensar na criança e preocupar-se em ouvi-la é também levar em conta o contexto social, cultural e econômico, bem como a conjuntura que envolve o binômio risco e proteção no qual ela está inserida (Rodrigues, Gonçalves, \& Teixeira, 2011).

\section{Ações dos Profissionais na Avaliação da Criança}

A análise da literatura revista no presente artigo sugere ser importante a existência de um protocolo de avaliação da criança no âmbito da qualidade da interação pais e filhos que inclua o reconhecimento da narrativa da criança no contexto em que se insere, bem como escutar o que ela tem a dizer sobre como ela vê o mundo que a cerca. Dessa forma, será possível compreender a dinâmica das interações a partir do olhar que ela apresenta, com a linguagem dela, validando a história que ela descreve (Costa \& Miragem, 2012; Saywitz et al., 2010). 
Compreende-se, assim, que as ações do profissional no contexto psicossocial devem ser desempenhadas, demonstrando disponibilidade e preparo, por meio de planejamento prévio para ouvi-la. Entende-se que o foco deve estar direcionado aos sentimentos de como a criança vivencia as mudanças existentes, ou que estão na iminência de ocorrer na organização familiar com a separação dos pais (Pereira \& Matos, 2008; Saywitz et al., 2010; van Nijnatten \& Jongen, 2011).

Considerando que a criança é participante ativa do processo, possibilitar sua expressão não significa querer que ela verbalize com quem quer residir, é necessário ir além (Cashmore, 2011; Cashmore \& Parkinson, 2008; Cashmore \& Parkinson, 2009). É preciso analisar, a partir de sua visão do contexto familiar, como ela está se sentindo, em que circunstâncias se sente protegida e segura, ouvida e atendida (Saywitz et al., 2010). E, mais do que isso, permitir que a criança participe, argumente, reflita e decida em conjunto com os adultos que tomam decisões a seu respeito para promoção de sua autonomia (Costa et al., 2009; Costa \& Miragem, 2012).

Assim, durante a avaliação, é importante que o contato do profissional com a criança seja realizado em um espaço lúdico e seguro, com recursos extraídos do universo infantil que facilitarão a construção da confiança entre ambos, favorecendo liberdade para expressar-se de forma singular e manifestar suas necessidades e angústias (Ribeiro, 2010; Saywitz et al., 2010; van Nijnatten \& Jongen, 2011). O uso de recursos formais, tais como testes psicológicos (CFP, 2003; Emery, Otto, \& O’Donohue, 2005; Lago, 2008; Lago, Amaral, Bosa, \& Bandeira, 2010; Lago \& Bandeira, 2008; Pereira \& Matos, 2008; Symons, 2010) permite complementar a entrevista e a observação, componentes da avaliação. Além disso, o uso desses instrumentos favorece ao profissional conhecer a criança por meio de suas expressões e relatos a respeito de si mesma, de sua interação com os outros membros da 
família e com o meio social (Lago, et al., 2010; Lago \& Bandeira, 2008; Pereira \& Matos, 2008).

No transcurso da entrevista com a criança, o profissional poderá recorrer a outros recursos não formais, como por exemplo, desenho, brinquedos ou jogos lúdicos, que podem ser úteis como ferramentas de apoio à narrativa infantil, servindo para acolher, compreender, investigar e intervir, além de auxiliar na intermediação no acesso à criança (Lago, 2008; Ribeiro, 2010; Rodrigues \& Lima, 2006; Saywitz et al., 2010; van Nijnatten \& Jongen, 2011). Considera-se que as ações sugeridas durante a entrevista, aos profissionais, propiciam espaço de segurança e confiança para a criança expressar de modo livre e tranquilo suas ideias, pensamentos e sentimentos a respeito de experiências vividas no seu contexto familiar e social (Saywitz et al., 2010; van Nijnatten \& Jongen, 2011).

\section{Considerações Finais}

O objetivo deste artigo foi refletir sobre a importância de escutar as narrativas da criança a respeito de suas vivências, sentimentos e expectativas perante a separação e a disputa parental concernente à sua guarda, no decorrer da avaliação psicossocial no contexto da Justiça. Para tal, efetuou-se pesquisa em estudos que pautam reflexão sobre avaliações realizadas com crianças e que consideram sua livre expressão conforme preconiza a Convenção sobre os Direitos da Criança (UNICEF, 1990). Na literatura científica, defende-se que a criança deve ser vista como participante ativa e não como vítima do litígio pósseparação/divórcio (van Nijnatten \& Jongen, 2011). Propõe-se, também, que o profissional busque ter conhecimento especializado nessa área, tendo em vista a complexidade que se apresenta nas famílias em litígio que recorrem à Justiça para a definição da guarda (Pessina \& Mendes, 2012). Aliada à complexidade, a singularidade de cada família dificulta uma 
padronização de instrumentos a serem utilizados pelos profissionais no transcurso da avaliação (Lago, 2008; Lago \& Bandeira, 2008).

Durante o processo de avaliação psicossocial, que tem como base a entrevista, o psicólogo pode utilizar testes projetivos e entrevista semiestruturada (Lago, 2008; Lago \& Bandeira, 2008; Pereira \& Matos, 2008), além de poder usar recursos não formais como brinquedos, jogos lúdicos e desenhos com o intuito de favorecer a interação com a criança. Com isso, ela poderá expressar-se de modo que o profissional possa identificar suas necessidades e sentimentos, validando-a como agente empreendedor e responsável por seus próprios direitos (Ribeiro, 2010; Rodrigues \& Lima, 2006; van Nijnatten e Jongen, 2011).

Conforme proposto neste artigo, valorizar a voz da criança em protocolos de avaliação objetiva contribuir diante da pouca literatura publicada no Brasil sobre esse tema, que revela a necessidade de desenvolverem-se mais pesquisas nesse campo a fim de proporcionar avanços na área (Lago, 2008; Lago \& Bandeira, 2008). Para os profissionais que avaliam crianças no âmbito de família, a utilização de ações que favoreçam a expressão do ponto de vista da criança nos assuntos familiares que lhe dizem respeito (Birnbaum \& Saini, 2012), contribui no reconhecimento de sua capacidade em participar, argumentar, refletir e decidir juntamente com os adultos que abordam as mudanças que estão ocorrendo em sua vida (Costa \& Miragem, 2012), bem como propicia o desenvolvimento de sua autonomia (Costa et al., 2009) no contexto de separação/divórcio parental. Além disso, considerar o ponto de vista da criança possibilita que as decisões tomadas na instância judicial sejam mais adequadas à realidade de suas necessidades, visando a favorecer a garantia de seus direitos fundamentais (Santa Rosa et al., 2014). 


\title{
ARTIGO TEÓRICO 2
}

\section{O Sofrimento da Criança na Vivência da Disputa de Guarda no Contexto da Justiça ${ }^{1}$}

\author{
Marcia Regina Ribeiro dos Santos
}

\section{Resumo}

A partir de uma revisão de literatura, este artigo visa refletir e destacar a importância da expressão e identificação do sofrimento da criança no contexto judicial de disputa de guarda, apoiando-se no princípio do melhor interesse da criança. Para os profissionais da equipe psicossocial que realizam a avaliação da criança nos casos de disputa de guarda, destacar esse sofrimento permitirá intervir, de modo a torná-lo visível para os pais que estão envolvidos no conflito entre eles. Os profissionais avaliadores poderão orientar os pais, esclarecendo-os sobre os riscos emocionais vivenciados pela criança, destacando o impacto no seu processo de desenvolvimento e bem-estar. Além disso, os pareceres técnicos enviados aos magistrados pontuarão a expressão da criança a fim de que possa ser considerada em sua tomada de decisão, independentemente dos pontos de vista dos pais e dos advogados que buscam enfatizar o conflito.

Palavras-chave: Sofrimento da criança, disputa parental, separação conjugal, Justiça.

\footnotetext{
${ }^{1}$ Este artigo foi publicado na Revista Portuguesa de Pedagogia, vol. 48, n. 1, p. 25-37. Ele está apresentado no formato da revista, de acordo com as normas da Língua Portuguesa de Portugal.
} 


\section{Introdução}

Com base em revisão de literatura, este artigo tem como objetivo destacar a expressão do sofrimento da criança durante disputa de guarda e regulamentação de visita, por ocasião da separação/divórcio do par parental, durante a avaliação psicossocial realizada na Justiça. Nessas situações, torna-se evidente a sobreposição do litígio parental, pelos progenitores, aos sentimentos de dor e perda expressos e vividos pelos filhos. Juras e Costa (2011a) conceituam divórcio destrutivo como brigas permanentes após a separação conjugal/marital ou divórcio, com dificuldade em cuidar e em cooperar nos cuidados com os filhos, envolvimento de terceiros no conflito, incluindo familiares, polícia e Justiça.

O trabalho dos profissionais, particularmente os avaliadores psicossociais, deve possibilitar e validar a expressão do sofrimento da criança para intervir na dinâmica familiar favorecendo, junto dos pais, a organização relacional propiciadora do bem-estar dos filhos. Assim, devem focar-se nas crianças, em seus sentimentos, vozes e expressões nos momentos de rutura e mudanças na estrutura familiar não apenas como fonte de informação, mas como seres humanos em desenvolvimento e com direito a serem tratadas com respeito e dignidade (Baker \& Brassard, 2013; Johnston, Roseby, \& Kuehnle, 2009; Kelly, 2012; Pereira \& Matos, 2008).

Com o aumento da taxa de divórcio e de separação conjugal, os profissionais que atuam no âmbito da avaliação psicossocial na Justiça devem tentar compreender como as crianças vivenciam as mudanças que estão ocorrendo em suas famílias. Avanços na legislação buscam atender ao princípio do melhor interesse da criança conforme destacado na Convenção sobre os Direitos da Criança pela Assembleia Geral das Nações Unidas, em 20 de novembro de 1989 e que entrou em vigor em 2 de setembro de 1990. O Brasil, como um dos Estados Parte, assumiu compromisso com a proteção da criança sendo que o Estatuto da Criança e do Adolescente, Lei 8.069 de 13 de julho de 1990, do ponto de vista legal, registra esse compromisso (Johnston et al., 2009; Kelly, 2012; Monteiro, 2010; UNICEF, 1990). 
De acordo com Monteiro (2010), um Comitê criado pela Convenção sobre os Direitos da Criança (UNICEF, 1990) no intuito de supervisionar a aplicação do que ficou estabelecido no referido Tratado esclarece, no Comentário Geral 5 (CRC/GC/2003/05) referente ao princípio do melhor interesse da criança, que é necessário haver medidas ativas do Governo, Parlamento e Tribunais de modo a verificar-se de que forma as suas decisões e ações são ou serão definidas pelo melhor interesse da criança. Assim, os magistrados, ao determinarem a realização da avaliação aos profissionais da equipa psicossocial no âmbito de disputa de guarda consideram que estes têm competência na realização dessa tarefa. Portanto, aos profissionais é requerida especialização sobre avaliação de criança no contexto de disputa de guarda a fim de evitar vieses que possam prejudicar o bem-estar da criança. Acrescente-se que esse tipo de avaliação é considerado uma das práticas mais difíceis, se não a mais complexa, a ser empreendida pelos profissionais que atuam nessa área (Grisso, 2003; Huss, 2009; Patel \& Choate, 2014).

O United Nation High Commissioner for Refugees (UNHCR) esclarece haver diferença entre determinação e avaliação do melhor interesse da criança. A determinação ocorre no processo formal (jurídico) que contempla as decisões dos juízes no equilíbrio dos aspetos relevantes e na apreciação da solução mais adequada. A avaliação, por sua vez, é feita por uma equipa de profissionais para tomar providências em relação às crianças em suas necessidades específicas e únicas com a participação dela nesse decurso. Assim, a avaliação baseada no princípio do melhor interesse da criança e realizada pelos profissionais de uma equipa psicossocial envolve a preservação do bem-estar daquela, respeitando o seu grau de maturidade e a sua individualidade na garantia do seu saudável desenvolvimento. Para tanto, considera-se relevante a preservação da qualidade da interação entre a criança e sua família. Desse modo, ainda que os pais estejam separados, o desenvolvimento biopsicossocial do(s) 
filho(s) deve ser preservado a despeito das diferenças que os levaram à rutura da convivência conjugal.

\section{Percursos pós-separação/divórcio}

Um dos percursos que a separação conjugal ou o divórcio pode seguir é o denominado adaptativo (Lamela, Castro, \& Figueiredo, 2010; Shienvold, 2011): as mudanças colocadas pela separação são ultrapassadas e o par parental consegue atender às necessidades dos filhos. A criança, por sua vez, consegue adaptar-se às transições impostas pela separação/divórcio. Em média, durante os dois primeiros anos de separação podem ocorrer confusão nos papéis conjugais e parentais com práticas descoordenadas nos cuidados com os filhos, limitações na comunicação e alto nível de estresse. No entanto, após esse período de tempo, as condições de ajustamento e o bem-estar psicológico retornam ou são superiores ao modo como eram antes do rompimento conjugal (Lamela, et al., 2010; Shienvold, 2011).

Assim, a prática da parentalidade após a separação/divórcio dependerá da motivação do pai e da mãe para desempenharem essa função. A motivação para o exercício parental e a superação do conflito parental interferem na qualidade da interação com os filhos, para o atendimento de suas necessidades e a consequente diminuição do seu sofrimento (Lamela, et al., 2010; Pereira \& Matos, 2008; Pinto \& Pereira, 2005; Landsford, 2009; Shienvold, 2011).

O outro percurso relacional que a separação/divórcio pode seguir é o denominado destrutivo, de alto-conflito e de conflito interparental (Birbaum \& Bala, 2010; Johnston et. al., 2009; Juras \& Costa, 2011a; Lamela et al., 2010; Lucas, Nicholson, \& Erbas, 2013; Pereira \& Matos, 2008; Sani, 2008; Soares, 2013) que pode ter emergido ainda antes da rutura conjugal, mantém-se durante esta etapa e perdura posteriormente a este momento. No presente artigo pretende-se destacar o impacto sobre a criança da manutenção deste antagonismo entre os pais, que se carateriza por dificuldades comunicacionais, no âmbito das quais os filhos se 
tornam potencialmente "invisíveis". Alguns destes casos podem envolver episódios de violência física a que a criança fica exposta ou nos quais ela está ativamente envolvida, o que lhe gera sofrimento e pode comprometer-lhe a saúde mental e o desenvolvimento a vários níveis (Birbaum \& Bala, 2010; Johnston et. al., 2009; Juras \& Costa, 2011a; Lamela et al., 2010; Lucas et al., 2013; Pereira \& Matos, 2008; Sani, 2008; Soares, 2013).

\section{O bem-estar da criança e o debate judicial da guarda}

Conforme destaca Monteiro (2010), o conhecimento sobre a infância é escasso e não linear do ponto de vista da cronologia. O autor expõe, de modo resumido, que a história da infância demonstra o desconhecimento subjacente à desvalorização das crianças, por serem percebidas como inferiores, consideradas propriedade e objeto de violência. Monteiro (2010) afirma que houve um conhecimento tardio em torno da criança como ser humano em desenvolvimento, que requer cuidados específicos. Na contemporaneidade, o reconhecimento pelo respeito em relação à criança como sujeito de direitos, em razão da imaturidade e vulnerabilidade inerentes às necessidades de desenvolvimento é, finalmente, estabelecido.

Ao se avançar na história da família e, mais especificamente, nos casos raros das famílias em que ocorria separação ou divórcio conjugal, até os séculos XVI e XVII, pelo menos nos Estados Unidos, a guarda invariavelmente era concedida ao pai por razões econômicas. Os filhos eram considerados propriedade dos pais. Posteriormente, passou-se a entender que o bem-estar da criança estava associado à mãe, sendo ela dotada de condições para a assumir a guarda dos filhos, com o suporte financeiro do pai (Ackerman, 2006; Fuhrmann \& Zibbell, 2012, Grisso, 2003).

No século XIX, com o aumento da taxa de divórcios e a disputa pela guarda, tornou-se comum conceder à mãe a guarda dos filhos, em especial a criança até cerca de sete anos, posteriormente, alargando-se até aos doze anos. Entretanto, a condição de disputa passou a 
acirrar o conflito entre os valores morais em relação à conduta da mãe e a obrigatoriedade do apoio financeiro paterno quando a mãe começou a trabalhar fora de casa. Com o advento do princípio do melhor interesse da criança os magistrados passaram a decidir partindo de reflexões de ordem subjetiva. Atualmente os juízes têm privilegiado homologar o acordo feito pelo par parental preferindo-se a guarda compartilhada, sendo que a criança permanece residindo com a mãe e definindo-se o tempo com o pai não guardião para a visitação. A pensão alimentícia passou a ser estipulada de acordo com as regras legais (Ackerman, 2006; Fuhrmann \& Zibbell, 2012, Grisso, 2003).

A imprecisão gerada pelo princípio do melhor interesse da criança pode favorecer o acirramento do litígio, passando a haver forte confiança no critério judicial, com a delegação da gestão parental no juiz, no concernente à decisão sobre a disputa. Apesar disso, a Justiça, movida pela busca em ativar as medidas que lhe são primordiais no que diz respeito ao apregoado pela Convenção sobre os Direitos da Criança (UNICEF, 1990), reconhece necessitar do auxílio de outros saberes. Desse modo, ao repassar o caso para as outras áreas das Ciências Humanas, Sociais e da Saúde, emerge o debate acadêmico em torno da obtenção da informação sobre se a criança está ou não sendo beneficiada, naquele momento, nas mudanças da organização familiar. Esse cuidado refinado no cumprimento da aplicação legal pode dificultar o prognóstico da tomada de decisão, algumas vezes aumentar o conflito parental, bem como intensificar a tática adversarial delongando o processo judicial (Ackerman, 2006; Fuhrmann \& Zibbell, 2012, Grisso, 2003; Kohm, 2008, Monteiro, 2010; UNICEF, 1990).

O estabelecimento de prática multidisciplinar que abranja profissionais do Direito, da Psiquiatria, da Psicologia, do Serviço Social, da Pedagogia, entre outras, com o contínuo aperfeiçoamento por meio de pesquisas, possibilitará potenciar a garantia da proteção, do desenvolvimento e da autonomia da criança. A sociedade autoriza a Justiça a decidir e esta, 
em determinados casos, recorre aos profissionais das referidas áreas para que eles identifiquem as competências parentais nos cuidados com os filhos. No caso de guarda, além de a Justiça determinar a investigação das condições do bem-estar da criança e, embora a Justiça presuma que pai e mãe sejam competentes, a investigação objetivará, também, comparar as habilidades e as condições para o exercício da parentalidade, tendo por referência o melhor interesse dos filhos (Emery, 2012; Fuhrmann \& Zibbell, 2012; Grisso, 2003).

\section{A criança no contexto da disputa de guarda}

Raposo et al. (2011) investigaram o impacto da separação/divórcio na vida e bem-estar da criança decorrente das mudanças que este evento origina, verificando que a literatura enfatiza o efeito disruptivo da rutura conjugal. Para Raposo et al. (2011) e Soares (2013) há uma diversidade de padrões de comportamento na criança que variam entre a psicopatologia, particularmente sintomatologia depressiva, e a ausência de indicadores clínicos. A explicação para tal variabilidade abrange um conjunto de condições individuais e do contexto em que a criança está inserida, à semelhança ao que ocorre nas crianças de famílias cujos pais não se separaram.

Segundo Raposo et al. (2011) há escassez de estudos que analisem a separação/divórcio como um evento de transição no desenvolvimento familiar e individual e, como tal, possa ser um fator promotor de novas possibilidades desenvolvimentais. Shienvold (2011) esclarece que os antagonismos existentes no conflito podem ser construtivos. Isso significa que a avaliação psicossocial relativa à guarda pode representar oportunidade para a família encontrar alternativas para reelaboração de suas dificuldades, na retomada de resoluções de seus conflitos (Barbosa \& Castro, 2013; Pessina \& Mendes, 2012). 


\section{Indicadores do sofrimento na criança}

A reflexão que moveu a escrita deste artigo tem por base a possibilidade de vivência do sofrimento da criança durante a disputa da sua guarda, e que pode ser detetada durante a realização da avaliação psicossocial. A preocupação apontada por vários autores (Birbaum \& Bala, 2010; Cohen \& Levita, 2011; Johnston et al., 2009; Juras \& Costa, 2011a; Lucas et al., 2013; Pereira \& Matos, 2008; Sani, 2008; Shaw, Öhman, \& Koppen, 2013; Soares, 2013; Stover, 2013) remete para a exposição da criança às intermináveis contendas entre seus pais, que afetam o seu desenvolvimento. Johnston et al. (2009) chamam a atenção para o fato de a criança correr o risco de se tornar despercebida pelos pais, pela Justiça e pelos profissionais que a acompanham, em razão da beligerância parental expressa no âmbito judicial.

Lucas et al. (2013), Pereira e Matos (2008), Pinto e Pereira (2005) e Raposo et al. (2011), ao estudarem as famílias nucleares intactas e as famílias em que os pais estão separados, ou não são residentes, verificaram que não é a separação ou o divórcio que acarreta sofrimento na criança a ponto de serem danosos para a sua saúde mental, mas a existência de conflito entre os pais. Os fatores mais identificados como contribuindo para o surgimento de prejuízos nas crianças são: sintomas psicopatológicos em um ou em ambos os pais, a condição financeira do pai e da mãe e o modo como os pais conduzem a coparentalidade. Raposo et al. (2011) observaram que, empiricamente, não é possível afirmar se, a médio ou longo prazo, a criança irá apresentar problemas de ajustamento associados ao divórcio. Tal entendimento deve-se à presença de variáveis como caraterísticas individuais e o meio ambiente em que a criança se desenvolve. Todavia, Raposo et al. (2011) e Shienvold (2011) defendem que as crianças na idade pré-escolar são particularmente vulneráveis aos conflitos entre os pais em razão da idade e imaturidade em compreender as mudanças que estão ocorrendo em sua família durante a separação/divórcio.

Costa e Sani (2007), MacMillan, Wathen e Varcoe (2013), Raposo et al. (2011), Sani (2008) e Soares (2013) destacam que nas famílias em que os pais conseguem superar as 
dificuldades inerentes ao momento da separação, são capazes de ajudar os filhos a enfrentarem as mudanças criadas pela rutura. Ademais, concluem que, na maioria das crianças cujos pais se separam/divorciam, há ausência de consequências funestas.

A separação/divórcio dos pais obrigam as crianças, em qualquer etapa do desenvolvimento, a adaptarem-se a muitas mudanças em suas vidas (Raposo et al., 2011). Dentre os agentes estressores relacionados com o contexto familiar destacam-se as alterações na condição socioeconômica, mudança de residência e de escola, e mudanças no tempo para estar com o pai e com a mãe. As crianças podem apresentar vergonha, medo do abandono de um ou de ambos os pais, fantasias de reconciliação, parentificação e conflito de lealdade. Dependendo da idade e vulnerabilidade, a criança pode sentir sintomas depressivos, ter baixo rendimento escolar, agressividade, mau comportamento e dificuldades no relacionamento com pares, professores, pais e/ou família extensa (Pereira \& Matos, 2008; Shienvold, 2011).

Torna-se necessário, portanto, que os profissionais de equipas psicossociais identifiquem o contexto em que a criança está inserida bem como as dinâmicas entre os seus pais separados/divorciados para, caso seja considerado necessário, sejam encaminhados para a rede de atendimento fora do âmbito judicial. Essas ações são importantes no intuito de tornar as crianças mais visíveis, mais validadas a nível dos seus sentimentos, expectativas e desafios, nesse momento de mudanças fundamentais da sua vida, reduzindo o seu sofrimento (Barbosa \& Castro, 2013; Costa \& Miragem, 2012; Gonçalves, 2012; Monteiro, 2010; Sani, 2008).

\section{Perspetivas futuras relativas à participação da criança em contexto judicial de separação/divórcio}

Ackerman (2006), Fuhrmann e Zibbel (2012), Grisso (2003), Huss (2009) e Sthal (2011) têm demonstrado que a realização de entrevistas com a criança e seus familiares, no contexto da Justiça, bem como a utilização de testes psicológicos, além de visitas às residências e às escolas, tem possibilitado identificar o sofrimento da criança durante a disputa de guarda e 
regulamentação de visita, destacando a participação desta. Estes autores têm realçado o conhecimento sobre o impacto que o conflito de lealdade aos pais acarreta à criança envolvida na disputa parental.

Entretanto, a ambiência judicial, por partir de pontos de vista antagónicos dos diferentes envolvidos, favorece a expressão do litígio e, em certos momentos, tensões no acirramento da disputa ao ocupar-se especificamente da guarda, visitação dos filhos e aporte financeiro. Assim, a participação da criança neste contexto tem sido discutida, requerendo o desenvolvimento de mais pesquisas, com vista a necessidade de melhor preparo dos profissionais que realizam a avaliação, conforme já exposto anteriormente (Bell, Cashmore, Parkinson, \& Single, 2013; Emery, 2012; McIntosh, Wells, Smyth, \& Long, 2008; Pereira \& Matos, 2008; Pinto \& Pereira, 2005).

Como proposta alternativa, a mediação tem sido apresentado como uma opção para diminuir o sofrimento da criança (Emery, 2012; Hart, 2009; McIntosh et al., 2008). Embora não seja o objetivo do presente artigo esgotar esse tema, destacam-se duas possibilidades de mediação que envolvem a criança no contexto de disputa de guarda: a Child Focused (CF) e a Child Inclusive (CI). A Child Focused (CF) é um processo de mediação referenciado por Emery (2012) que se centra na recolha de informação nos pais, embora o interesse, em todo o processo, esteja focado na criança, sendo que esse profissional raramente conversa com a criança.

A mediação denominada Child Inclusive (CI) tem sido utilizada por Hart (2009) e McIntosh et al. (2008). Nessa modalidade de mediação há duas possibilidades: a) um profissional treinado entrevista a criança e conhece seus desejos previamente à entrevista aos pais. O profissional utiliza instrumentos de coleta, tais como histórias infantis, desenhos, jogos, brinquedos. Posteriormente, o referido profissional que esteve com a criança leva para as sessões com o mediador e com os pais as informações que recolheu na sua avaliação e que 
deverão contribuir para estabelecer as condições que garantam o bem-estar da criança; b) a segunda possibilidade de desenvolver a medição Child Inclusive (CI) (Hart, 2009; McIntosh et al., 2008) inclui a participação da criança e dos pais apenas nas questões que lhe dizem respeito, como por exemplo, tempo de visitação com o pai não guardião. Todavia, a finalização da mediação é efetuada apenas entre o profissional e os pais. Em ambas as possibilidades do Child Inclusive (CI) o objetivo é manter a criança preservada dos momentos de tensão que o contexto de disputa naturalmente gera. Tanto nas abordagens Child Focused (CF) ou Child Inclusive (CI) os profissionais reconhecem o sofrimento da criança e buscam preservá-la do conflito entre os pais.

Nos formatos de mediação aqui expostos, o enfoque está no fortalecimento da competência parental e na visibilidade dos desejos e sentimentos da criança. Assim, a intenção dos profissionais é motivar e fortalecer os pais a direcionar a sua atenção para os cuidados e necessidades dos filhos neste contexto de disputa da guarda, tendo como ponto fulcral o respeito pela criança e pelo seu direito ao bem-estar e a um contexto de desenvolvimento positivo (Emery, 2012; Hart, 2009; McIntosh et al., 2008).

\section{Considerações finais}

As mudanças que estão ocorrendo nas famílias no mundo contemporâneo demandam práticas multidisciplinares atendendo ao princípio do melhor interesse da criança. E isso se aplica ao contexto de avaliação psicossocial na Justiça. A preocupação com o saudável desenvolvimento da criança acarreta a busca pela preparação e adequação de profissionais especializados nessa complexa e intrincada tarefa. As pesquisas aqui apresentadas mostram que os pais não estão sensíveis ao sofrimento dos filhos por estarem envolvidos em intenso conflito entre eles. O profissional necessitará ter conhecimento sobre o desenvolvimento infantil, as competências parentais e os diferentes graus de conflito interparental, bem como 
os potenciais efeitos adversos destes sobre as crianças. Com isso, um sistema de Justiça menos adversarial, em conjunto com a família, favorecerá a construção de medidas e tomadas de decisão a favor do bem-estar da criança (Emery, 2012; Hart, 2009; Huss, 2009; Sani, 2007; Soares, 2013). A discutida e necessária fundamentação sobre o princípio do melhor interesse da criança é responsabilidade do trabalho inter e multidisciplinar entre os profissionais das áreas do Direito, Psiquiatria, Psicologia, Serviço Social e outras, para que os juízes possam ter o apoio e o devido embasamento científico para as suas tomadas de decisões. Para tanto, no âmbito judicial de guarda e visitação, conhecer e avaliar o sofrimento da criança torna-se essencial a fim de evitar prejuízos extensivos a sua saúde mental e física. Além disso, conhecer esse sofrimento e as expressões da criança nesse contexto capacita os profissionais para que suas avaliações e intervenções sirvam de apoio para as famílias que passam pelo processo de separação ou divórcio, permeado por conflito em graus diferenciados. Acrescente-se, ainda, que ao se permitir o debate acadêmico e a especialização dos profissionais na interface com a Justiça, agilizam-se providências e ampliam-se possibilidades para assegurar o desenvolvimento de políticas públicas na garantia dos direitos da criança tal qual destaca a Convenção sobre os Direitos da Criança (UNICEF, 1990) conforme apontam Emery (2012), Grisso (2003), Hart (2009), Kohm (2008), Monteiro (2010).

Do ponto de vista prático, conhecer o sofrimento da criança é relevante em dois aspectos distintos: o primeiro é relativo à criança e aos seus pais. Os profissionais da equipa psicossocial, ao permitirem a expressão do sofrimento da criança no contexto judicial em situações de disputa de guarda cuja relação interparental se configura como destrutiva ou de alto-conflito, poderão auxiliá-la a encontrar recursos de enfrentamento, promovendo a resiliência nas relações com adultos e pares, a fim de minimizar a probabilidade de repetição dos comportamentos a que está/esteve exposta. Os profissionais podem intervir junto dos pais esclarecendo-os e orientando-os sobre os riscos aos quais a criança está exposta, enfatizando a 
sua vulnerabilidade desenvolvimental. Poderão ainda encaminhar a criança e/ou respetivos pais para a rede de profissionais fora do âmbito judicial de maneira a que sejam criadas condições familiares adequadas à promoção do desenvolvimento e bem-estar da criança.

O segundo aspecto diz respeito ao suporte à determinação judicial. Por meio de pareceres técnicos fornecidos pelos profissionais da equipa psicossocial, o juiz poderá ter acesso à narrativa da criança independente dos vieses de seus pais e advogados destes. Assim, o juiz poderá decidir considerando, também, a voz da criança, podendo alterar o curso do processo, pois terá elementos para reconhecer a expressão de sofrimento pontuada pela criança durante a realização do estudo psicossocial. As informações relativas ao sofrimento da criança estarão contidas no parecer e propiciarão ao magistrado a articulação de recursos dos órgãos competentes para proteção e segurança da criança. O conhecimento (e o reconhecimento) desse sofrimento em situações litigantes pode fornecer subsídios consistentes aos magistrados nas decisões em torno da disputa da guarda. Com base no princípio do melhor interesse da criança, entende-se que a prioridade será sempre o bem-estar, a proteção e a garantia de sua integridade física, moral e emocional, em detrimento dos demais argumentos ou interesses por parte de seus pais e/ou responsáveis postulados por seus advogados.

A criança, ao ter sua voz e expressões representadas no processo pelos profissionais treinados e sensibilizados para identificar e validar o seu sofrimento, terá mais visibilidade para receber a proteção e a segurança que estão subjacentes à intervenção judicial. Desta forma, o sistema de Justiça estará mais próximo da realidade da criança, contribuindo para o atendimento de suas reais necessidades e favorecendo o seu saudável desenvolvimento biopsicossocial. 


\title{
Child Suffering in the Context of Judicial Parental Disputes
}

\begin{abstract}
Based on a review of the literature, this article aims to reflect on and highlight the importance of the child's expression and suffering within the context of judicial child custody disputes, drawing on the principle of the best interests of the child. For professionals in the psychosocial staff that perform the evaluation of the child in cases of child custody disputes, highlight this suffering allows them to intervene in order to make it visible to the parents involved in the conflict. Professional evaluators may guide parents, informing them of the emotional risks experienced by the child, and pointing out the impact on the child's development and well-being. Furthermore, the technical report of the evaluation provided to the magistrates should point out the expression of the child so that it be considered in their decisions, regardless of the views of parents and lawyers, who seek to emphasize the conflict.
\end{abstract}

Key words: Child suffering, parental dispute, marital separation, justice.

EI Sufrimiento de los Niños en la Experiencia de la Disputa de los Padres en el Contexto de la Justicia

\section{Resumen}

A partir de una revisión de la literatura, el presente trabajo tiene como objetivo reflexionar y destacar la importancia de la expresión y la identificación del sufrimiento del niño en el contexto de la disputa por la custodia judicial, basándose en el principio del interés superior del niño. Para los profesionales psicosociales que ejecutan la evaluación del niño en casos de custodia de menores, despegar este sufrimiento intervendrán con el fin de que sea visible para los padres que están involucrados en el conflicto entre ellos. Estos profesionales guiarán a los 
padres, explicando acerca de los riesgos emocionales experimentados por el niño, destacando el impacto en el proceso de desarrollo y bienestar. Además, la respuesta de la evaluación a los magistrados, a través de los informes técnicos, marcan la expresión del niño, de modo que el juez la considere en su decisión, independientemente de las opiniones de los padres y defensores que enfatizan el conflicto.

Palabras clave: Sufrimiento del niño, disputa de los padres, separación matrimonial, Justicia. 


\section{ARTIGO EMPÍRICO DO ESTUDO PILOTO}

Estratégias de enfrentamento dos filhos ao conflito conjugal no contexto da Justiça Children coping with marital conflict in Justice ${ }^{2}$

Estrategias de enfrentamiento de los niños en el conflicto conyugal en la Justicia

Marcia Regina Ribeiro dos Santos

Doutoranda do Programa de Pós-Graduação em Psicologia Clínica e Cultura

(PPGPsiCC) da

Universidade de Brasília

SHIN QI 7 Conj. 7 Casa 5, Lago Norte, 71515-070, Brasília DF, (61) 8162-1374

marciarrsantos@gmail.com

Mariana Martins Juras

Doutoranda do Programa de Pós-Graduação em Psicologia Clínica e Cultura

(PPGPsiCC) da

Universidade de Brasília

Quadra 205, Lote 3, Bloco A, Ap. 701, Ed. Green Towers, Águas Claras, 71925-000 Brasília DF, (61) 9968-1983, marijuras@gmail.com

\section{Liana Fortunato Costa}

Doutora em Psicologia Clínica pela USP

Docente Permanente do Programa de Pós-Graduação em Psicologia Clínica e Cultura

(PPGPsiCC) da Universidade de Brasília

SQN 104 BI. D Ap. 307, 70733-040 Brasília DF, (61) 3328-7439, lianaf@ terra.com.br

\footnotetext{
${ }^{2}$ Este artigo está em processo de avaliação por uma revista e está apresentado no formato exigido pelo periódico.
} 


\title{
Resumo
}

Este artigo discute estratégias de enfrentamento ao conflito adotadas por filhos cujos pais estão em processo de separação. A partir da avaliação psicossocial realizada em contexto judicial com crianças de uma família separada, analisaram-se quatro núcleos de sentido: percepção do conflito conjugal; estratégias de enfrentamento e autoproteção; apoio mútuo no subsistema fraternal e expectativas quanto à resolução do conflito. Evidenciou-se que as crianças são sujeitos ativos no contexto familiar conflituoso. Os avaliadores psicossociais devem atentar para o sofrimento e a resiliência das crianças, enfatizar suas estratégias de autoproteção no parecer enviado ao juiz, visando a preservar o melhor interesse da criança.

Palavras chave: Enfrentamento, crianças, separação conjugal, conflito conjugal

\begin{abstract}
The article analyzes the conflict coping strategies adopted by children whose parents are in the process of separation. Based on a psychosocial assessment within judicial context with children of separated families, four cores of meaning were analyzed: perception of marital conflict, coping and self-protection strategies, mutual support in the sibling subsystem, and expectations of resolution. The analyses showed that the children were active participants in the troubled family context. Psychosocial evaluators should consider the children's psychosocial suffering and resilience, and highlight the children's self-protection strategies in the report to the judge in order to preserve the child's best interest.
\end{abstract}

Keywords: Coping, children, marital separation, marital conflict

\section{Resumen}

El artículo analiza estrategias de enfrentamiento al conflicto adoptadas por niños cuyos padres están en proceso de separación. A partir de la evaluación psicosocial en el contexto judicial con niñas de una familia separada, se analizaron cuatro núcleos de sentido: percepción de 
conflictos marital, estrategias de enfrentamiento y auto-protección, apoyo mutuo en el subsistema fraterno y expectativas acerca de la resolución del conflicto. Los niños son sujetos activos en el contexto familiar conflictivo. Evaluadores psicosociales deben considerar el sufrimiento, resistencia y estrategias de autoprotección de los niños en el informe para el juez, para preservar el interés superior del niño.

Palabras clave: Enfrentamiento, niños, separacion conyugal, conflicto marital

\section{Estratégias de Enfrentamento dos Filhos ao Conflito Conjugal no Contexto da Justiça}

\section{Introdução}

Este texto trata do recorte de uma pesquisa qualitativa referente ao sofrimento da criança em relação ao litígio familiar no contexto da avaliação psicossocial na Justiça. O estudo aqui apresentado tem origem em uma investigação piloto referente à percepção da criança em relação ao conflito conjugal dos pais e enfoca estratégias de enfrentamento de filhos para essa situação. O contexto de acesso à criança foi o momento da avaliação psicossocial realizada para a tomada de decisão na concessão de guarda a um dos pais. Priorizou-se, portanto, a voz da criança no âmbito do Serviço de Assessoramento às Varas Cíveis e de Família (SERAF) do Tribunal de Justiça do Distrito Federal e Territórios.

O recorte foi feito pela coerência das respostas das crianças em relação aos objetivos da pesquisa, considerando-se as dificuldades inerentes a esse contexto. A voz infantil revelouse como instrumento privilegiado para construir a compreensão do jogo relacional conjugal no qual a criança está inserida e da qual é dependente (Minuchin, 1985; Minuchin, Nichols \& Lee, 2009). Com isso, o profissional avaliador terá mais elementos para fornecer ao juiz demandante do estudo psicossocial para garantia do atendimento ao melhor interesse da criança, conforme apregoado pela Convenção sobre os Direitos da Criança em Assembleia 
Geral das Nações Unidas, a 20 de novembro de 1989, que passou a vigorar em 1990, a Magna Carta das crianças (Monteiro, 2010).

\section{Os Filhos e a Separação Conjugal}

O divórcio é um fenômeno crescente no contexto das famílias brasileiras. O ano de 2010 apresentou o maior número de divórcios na história do Brasil, desde 1984. O Registro Civil apontou um aumento de 36,8\% no número de divórcios em relação ao ano de 2009 (IBGE, 2010). A dissolução conjugal traz novos desafios aos membros da família e à sociedade, pois é uma realidade que envolve mudanças em diversos níveis (individual, conjugal, familiar, comunitário, social e cultural).

Diante da realidade do divórcio, os filhos podem ser incluídos em conflito parental, especialmente nos casos que envolvem litígios no contexto da Justiça. As consequências do divórcio para os filhos podem ser várias e dependem da idade e gênero dos filhos e da relação dos pais quando casados e ao se separarem. Na fase inicial, é comum que as crianças sintam medo, insegurança, culpa, hostilidade, entre outros. A exposição dos filhos a brigas durante a união ou após a dissolução conjugal podem intensificar as consequências desfavoráveis ao desenvolvimento deles (Bojuwoye \& Akpan, 2009; Brito, 2008; Juras \& Costa, 2011a; Orgilés \& Samperb, 2011; Wallerstein, Lewis \& Blakeslee, 2002).

Ao se depararem com o divórcio dos pais, os filhos podem se comportar de diversas formas. Quando o conflito conjugal é frequente e presenciado pelos filhos, a notícia da separação pode não ser uma surpresa, diferentemente do impacto de uma separação que ocorreu quando não tinham conhecimento de conflitos que justificassem o fim do casamento (Bojuwoye \& Akpan, 2009; Brito, 2008). Ayad et al. (2002) afirmam que as consequências negativas do divórcio para os filhos são comuns a curto e médio prazo. Porém, a longo prazo, 
os filhos de pais separados não apresentaram diferenças significativas a respeito de condutas de risco maiores do que aquelas relativas aos filhos de pais que permanecem casados.

O processo de divórcio tem sido estudado nas diferentes fases do ciclo de vida familiar. O impacto nos filhos recém-nascidos ou muito pequenos é menor tendo em vista que eles ainda não se inseriram ativa e conscientemente nas relações familiares. Quando os filhos se encontram na idade do início da escolaridade, o divórcio tende a impactá-los mais intensamente, uma vez que já conseguem compreender parte da realidade que os circunda, porém ainda com poucos recursos para entender e lidar com os conflitos entre os pais. A adolescência é considerada uma fase de muitas transformações e o divórcio pode ensejar maior rebeldia por parte dos filhos, ou então, contribuir para um amadurecimento em seu desenvolvimento. Nessas duas últimas fases relatadas, os filhos podem ser envolvidos ou sentirem obrigação de mediar os conflitos parentais, podendo ensejar um processo de triangulação rígida e/ou parentalização (Brito, 2005b; Costa, Penso, Legnani \& Sudbrack, 2009; Juras \& Costa, 2011a; Minuchin et al., 2009).

Quando o relacionamento parental é conflituoso e destrutivo, os filhos podem ser levados a intermediar esses contatos, gerando uma sobrecarga emocional que pode prejudicar seu desenvolvimento saudável quando criança ou adolescente. Quando há mais de um filho, esse legado pode ser transmitido ao filho mais velho ou ao filho mais sensível ao conflito parental. O processo de triangulação rígida interessa em especial aos profissionais que atuam em setor de avaliação psicossocial de Vara de Família, pois é um arranjo familiar comumente encontrado, além de acrescentar complexidade às tomadas de decisão desse contexto. Nesses casos, a ambiguidade observada tanto nos comportamentos parentais como no sofrimento da criança triangulada marca a compreensão do processo (Bowen, 1979; Juras \& Costa, 2011a; Santos \& Hamú, 2010). 
Os filhos podem desempenhar diversos papéis e comportarem-se de várias maneiras após vivenciaram o divórcio dos pais. Quando o sofrimento dos pais fica evidente, os filhos podem ser colocados no papel de cuidadores e confidentes de seus genitores ou do genitor que é considerado o mais fragilizado após o rompimento conjugal. Quando essa relação do filho como cuidador de seu genitor se torna um padrão, esse processo de inversão parental, chamado parentalização, pode trazer responsabilidades que estão acima da capacidade esperada de crianças e adolescentes (Boszormenyi-Nagy \& Spark, 2008; Brito, 2008; Juras \& Costa, 2011a).

Alguns comportamentos comuns dos filhos diante da separação dos pais, de acordo com Cerveny (2006), assemelham-se metaforicamente à "mala", "bala" e "cola". A primeira refere-se à transmissão de recados de um genitor ao outro quando esses não possuem um diálogo respeitoso. Comportar-se como "bala" indica que os filhos são usados para agredir o outro genitor por meio de xingamentos e desqualificações mútuas e, o último, representa o desejo dos filhos de voltar a unir os pais na condição de casados. Esses comportamentos demonstram que é comum os filhos entremearem seus pais, uma vez que são sujeitos ativos no sistema familiar.

Estudos longitudinais sobre divórcio demonstram que, quando os filhos percebem que existe uma relação cooperativa entre seus genitores após a dissolução conjugal, o relacionamento dos filhos com seus pais, outros familiares e pares tende a ser mais saudável. Por outro lado, quando a animosidade entre o par parental se torna o padrão relacional, os filhos podem ser levados à lealdade com um genitor e afastamento do outro e, respectivamente, com as famílias de origem (Ahrons, 2007; Brito, 2008).

A resiliência familiar e pessoal de crianças e adolescentes de pais separados também deve ser considerada para além dos aspectos do relacionamento parental que impactam no desenvolvimento dos filhos. Entende-se como resiliência a capacidade de a pessoa reagir às 
adversidades, expressando-se de modo fortalecido, oriundo de seus recursos emocionais e do contexto sócio familiar em que vive. Recursos e habilidades pessoais e familiares quando fortalecidos e incentivados tendem a contribuir para que esse processo de crise familiar alcance desenvolvimento ainda mais saudável para todos os membros da família. Ademais, as crianças devem ser consideradas sujeitos ativos nesse processo mesmo estando em uma relação assimétrica em relação aos pais (Maes, Mol \& Buysse, 2011; Walsh, 2003).

Um importante recurso familiar diante de um processo de separação dos pais é a existência de uma fratria ou grupo de irmãos. Nas situações de divórcios conflituosos, momentos de estresse e transformação familiar, pode haver intensificação ainda maior do relacionamento fraternal, visando a oferecer maior suporte aos seus membros (Goldsmid \& Féres-Carneiro, 2007; Juras \& Costa, 2011a; Muniz \& Féres-Carneiro, 2012; Silveira, 2009; Siméon, 2000).

Portanto, buscou-se aprofundar o conhecimento dos recursos e das estratégias que as crianças utilizam para o enfrentamento de situações em que se sentem emocionalmente ameaçadas, por exemplo, quando presenciam conflitos conjugais que envolvem a separação do casal ou o divórcio. Priorizou-se conhecer como a criança se expressa a partir da perspectiva de sua voz, enfocando, em especial, o contexto da Justiça.

\section{Método}

A avaliação psicossocial é realizada por profissionais de psicologia e serviço social que compõem a equipe de um tribunal. A prática estabelecida envolve a realização do estudo com a conclusão por meio de um parecer técnico direcionado ao juiz solicitante. Os procedimentos incluem atendimentos individuais e familiares, visitas às residências do requerente e do requerido e à escola da criança, e contatos com profissionais que acompanham a criança, ou o adolescente, em contexto psicoterápico (se, por ventura, houver). 
Os atendimentos podem ser realizados mediante diversas combinações, como por exemplo, dos responsáveis pela criança, geralmente os pais; de outros componentes da família; da criança em questão; de irmãos.

O caso apresentado é referente a uma família em disputa de guarda na Justiça. Para realizar a pesquisa, houve a submissão do projeto ao Comitê de Ética em Pesquisa, aprovado em 10 de setembro de 2012. Os nomes são fictícios para preservar o sigilo. O recorte para este artigo relaciona-se apenas à entrevista realizada entre a pesquisadora e as três crianças da família que estava em avaliação.

História familiar e processual: A separação do casal ocorreu quatro meses antes da realização do estudo e foi motivada por infidelidade conjugal por parte da esposa. A mãe das crianças tinha, à época, 35 anos de idade, estava civilmente casada, porém de fato encontravase separada do pai das crianças e trabalhava como gerente com renda mensal no valor aproximado de sete salários mínimos. Ela era a requerente de uma ação de guarda e responsabilidade em desfavor do pai das crianças, com quem foi casada por cerca de nove anos. Após a dissolução conjugal, ela saiu de casa e voltou a residir no mesmo terreno em que residia sua genitora, porém em casa distinta. A mãe, ao sair de casa, havia levado as filhas consigo, mas o pai em vários momentos de discussão entre o ex-casal ameaçou matar-se e matar o amante se ela não deixasse as infantes com ele. Diante dessa violenta ameaça, ela cedeu e deixou-as em companhia paterna. A mãe buscou a Justiça porque estava tendo dificuldades para manter contato com as filhas. Em audiência de justificação, o juiz havia determinado que até a finalização do estudo psicossocial a guarda seria compartilhada.

O pai das crianças estava com 42 anos de idade, apresentou-se como católico não praticante, trabalhava como contador com renda de oito salários mínimos. Ele continuou morando na casa adquirida pelo casal, sendo que, no mesmo terreno já residia sua genitora. As crianças que participaram do estudo frutos do casamento eram: Aninha, 8 anos de idade, 
estudante do $3^{\circ}$ ano do ensino fundamental; Bibinha, 7 anos de idade, estudante do $2^{\circ}$ ano do ensino fundamental e, Ceci, 3 anos de idade. O núcleo familiar paterno contava com a ajuda de uma empregada doméstica, de 31 anos de idade. As avós materna e paterna se mantinham próximas às crianças. O núcleo familiar paterno, especialmente o genitor, buscava transmitir às filhas valores religiosos por meio de orações diárias. Por sua vez, a mãe não compartilhava desses valores e, segundo o pai, ela era avessa à religião.

Para a realização da entrevista foi elaborado um roteiro em que constaram as seguintes perguntas: Você gosta de desenhar? Gostaria que você fizesse um desenho que conte a história da sua família. Quantos anos você tinha quando seus pais se separaram? Como foi a separação deles? O que aconteceu? O que você lembra? Eles brigavam? Você sabe por quê?? Você os viu brigando? Quantos anos você tinha quando seus pais começaram a brigar? $O$ que você fazia quando seus pais começavam a brigar? Onde você ficava? Como você se sentia nos momentos das brigas dos seus pais? Você acha que as brigas vão acabar? Quando? Quem decide se as brigas vão ou não acabar? Que idade você tinha quando o processo na Justiça começou? Você acha que o processo vai ter fim? Quando? Como? Quem decide se o processo vai ou não acabar?

Para os fins deste texto, a entrevista e os dados obtidos durante a realização do estudo pela profissional avaliadora à respeito da história familiar e processual foram considerados como dados para análise.

Além da entrevista, utilizou-se o desenho como recurso para a comunicação das crianças. Inicialmente pensou-se em obter-se informações apenas das duas mais velhas, porém diante da insistência de Ceci, com três anos de idade, permitiu-se sua inclusão, já que ela não se conformou em não participar desse momento. Durante a entrevista, todas atenderam à solicitação de fazerem um desenho cada uma, em folhas separadas (Anexos 3, 4 e 5). Elas desenharam e conversaram animadamente, observando-se boa interação entre elas. Solicitou- 
se que as três crianças contassem a história da família por meio de desenho, individualmente. Em seguida, no grupo fraterno, pediu-se que cada uma apresentasse a família, contando a história que estava ali desenhada. Foi estabelecida uma conversa com as crianças enquanto desenhavam para esclarecer os elementos dos desenhos e para facilitar a compreensão da dinâmica da história contada sobre a família.

O desenho realizado por Aninha (Anexo 3) retrata toda a família junta, ao redor da árvore de Natal, comemorando. Todos os membros da família estão presentes em seu desenho: mãe, pai e as três filhas. O desenho é bem colorido e retrata todos sorrindo e felizes. Bibinha desenhou a si e suas irmãs entre os pais (Anexo 4), com pouca diferença de tamanho entre as figuras representadas, sem especificar algum tema. Todos estão sorrindo tal como o fez Aninha. Ceci desenhou vários círculos totalmente preenchidos com cores (Anexo 5), também repetindo parte do desenho da irmã mais velha, revelando representar bolas da árvore de Natal. Essa atitude valida a liderança, nesse momento, de Aninha, como mais velha do grupo, em direcionar um tema para servir de modelo e ser seguido pelas demais (Britto, 2002; Juras \& Costa, 2011a).

Após a transcrição da gravação, procedeu-se à interpretação das falas com base na proposta de Minayo (2014) que identifica núcleos de sentido na conversação.

\section{Resultados e Discussão}

A avaliação psicossocial tem dupla função: efetuar intervenções com a família e fornecer ao juiz solicitante subsídios para sua decisão (Costa et al., 2009). Para se compreender a dinâmica familiar, observa-se a organização e o funcionamento do sistema e dos subsistemas da família em avaliação (Minuchin, 1985, 1990; Minuchin, et al., 2009). Entretanto, para fins de discussão no presente artigo, considerou-se importante evidenciar a 
competência da família a partir do conhecimento que as crianças revelaram do convívio familiar.

Assim sendo, buscou-se reconhecer no desenho e nas falas da criança, as estratégias de enfrentamento dos conflitos entre os pais. A observância desses dois elementos, desenho e falas, proporcionou a apreensão de sentidos contraditórios presentes na forma como as crianças enfrentam a situação de conflito conjugal. Os sentidos contraditórios se referem ao movimento das crianças em aproximar-se e afastar-se do conflito conjugal. Em função da dificuldade de se considerar a presença dos desenhos, a fim de evitar a inclusão de anexos neste artigo, optou-se por centrar a análise nas falas. A partir da análise do material das conversações e dos desenhos, foram interpretados e construídos quatro núcleos de sentido: 1) Percepção do conflito conjugal pelas crianças; 2) Estratégias de enfrentamento e autoproteção das crianças; 3) Apoio mútuo dentro do subsistema fraternal; 4) Expectativas quanto à resolução do conflito.

\section{Percepção do Conflito Conjugal pelas Crianças}

Várias são as falas de Aninha que identificam sua percepção do que ocorre com os pais e dos comportamentos que podem facilitar a convivência dentro de casa. "Mas, também, eles não se separaram por causa das brigas, não”. As brigas dizem respeito a algo que aconteceu entre o casal, ela "sabe" da traição. As crianças possuem a habilidade de construir significados para a tomada de decisão de seus pais ao se separarem e, assim, conseguirem manter-se afastadas do conflito (Maes et al., 2011).

Aninha compreende que as brigas ocorreram depois da separação, por isso não associa a briga ao processo judicial. O casal está brigando por estar zangado um com o outro. Chama a atenção que Aninha consegue, durante a conversação, diferenciar-se de seus pais, pois ao identificar o aborrecimento na relação destes adultos, acredita que o envolvimento da família 
com a Justiça transcorre independente do conflito existente. Ademais, ela se refere aos pais de modo a não emitir juízo de valor sobre eles, tratando-os por "eles", ou seja, reconhece o subsistema parental como independente, bem como a si mesma como não pertencente a esse subsistema (Meynckens-Fourez, 2000).

Aninha: Na última briga deles, que eu me lembro, no ano passado, eles ficaram brigando no banheiro. O papai tava com cara de bravo! Era por causa da situação de separar, eu sei bem disso! Eu não sei, só sei que quando cheguei lá pra escovar meus dentes, eles saíram fora. É! Eu pensei: Ixi, com essa cara não é coisa boa! As crianças percebem o clima de animosidade entre seus pais por meio das brigas e das expressões faciais e comportamentais. Os filhos não aprendem sobre sua realidade apenas com o conteúdo do que os pais falam com elas, mas os sentimentos e expressões manifestos por seus genitores contribuem para a construção da percepção das crianças. Watzlawick, Beavin, \& Jackson, 2002) denominam esse tipo de comunicação como analógica, ou seja, é a comunicação que não é verbalizada, porém expressa de outras maneiras e pode estar ou não em consonância com que é dito.

Entrevistadora: E quando eles brigavam, o que vocês faziam? Aninha: Nada, de longe a gente via né? Se não, eles poderiam ficar nervosos com a gente. Bibinha: Ah, sei lá, a gente só via eles brigando, a gente não escutava nada, não prestava atenção! Nessas falas, observa-se que, a partir da percepção do conflito entre os pais, Aninha e Bibinha buscam estratégias de afastamento e distanciamento das brigas conjugais. As estratégias se constituem em definição de fronteiras claras e precisas que lhes proporcionam transitar pela casa, sem se misturarem com as brigas. Parece que procuram mapear o que se passa com os pais para decidirem como irão se conduzir no âmbito do espaço da residência.

Entrevistadora perguntando sobre o desenho: Tá todo mundo feliz no Natal? Aninha: É, porque é antes das brigas. O fato de as brigas terem iniciado ou intensificado após a separação traz sofrimento para a criança, porque percebe, mesmo com a adoção das 
estratégias de evitação de estarem no meio do conflito. Neste caso, a separação ocorrera quatro meses antes, e a cena incluída no desenho, a família unida por ocasião da comemoração do Natal (data cristã), evidencia sua percepção do que gostaria que continuasse a existir.

Observa-se, portanto, que as filhas dessa família pesquisada são sensíveis ao conflito entre seus pais, demonstrando que percebem o contexto de brigas que pode, inclusive ser intensificado pelo contexto jurídico. A Justiça brasileira, infelizmente, ainda se mostra como um espaço de fomentar as desavenças familiares, apresentando, por vezes, discursos individualistas, simplificadores e dicotômicos. A estrutura jurídica de colocar as partes em polos opostos em um processo judicial no qual deve autopromover-se e desqualificar o outro, favorece a manutenção e ampliação dos conflitos, que, por sua vez, fazem parte desse contexto (Juras \& Costa, 2011b).

A presença das crianças e dos adolescentes, nos processos jurídicos familiares que os envolvem, é fundamental. Entretanto, essa participação deve ser provida de cuidado e atenção aos seus direitos, não sendo adequado questionar os infantes acerca de decisões a serem tomadas a seu respeito, como guarda, visitação e pensão alimentícia. É importante oferecer um espaço de escuta aos filhos, a fim de compreender seus sentimentos, suas percepções e sua participação ativa na vida familiar (Brito, Ayres \& Amendola, 2006; Juras \& Costa, 2011a).

\section{Estratégias de Enfrentamento e Autoproteção da Criança}

Ao se analisar as estratégias de proteção e cuidado de Aninha consigo mesma e com as irmãs diante de um contexto conflituoso, observa-se o papel de liderança exercido por ela e seguido por Bibinha e Ceci. Sabe-se que a organização na fratria pode sofrer alterações ao longo do tempo, modificando-se a posição entre os irmãos (Britto, 2002). Aninha: A gente quase não pegava todas as brigas. Porque eles estavam fazendo outras coisas e eles só 
brigam no quarto. A gente quase não ia no quarto, agora a gente vai mais, porque agora tem computador lá. (...) Quando eu cheguei lá, eu fui lá, eles tavam brigando lá, aí eu fui pegar minha escova de dentes e saí, porque eu não queria entrar na briga.

Está claro como as meninas se protegiam das brigas. Primeiro identificaram o território do conflito: o quarto do casal, e os momentos nos quais o casal se encontrava junto, por exemplo, no banheiro. Aninha narra aqui uma situação noturna quando todos estão se preparando para dormir. Durante o período de brigas entre o casal, Aninha conta que elas deixaram de frequentar esse ambiente. Assim, evitavam contato mais próximo com os conflitos. Por outro lado, o banheiro é um espaço comum a todos da família. Nesse caso, as meninas entravam e saíam rapidamente para não se exporem ou não serem envolvidas na briga. Trata-se de uma forma de evitação que busca a proteção e também estrutura uma forma alternativa de relacionamento. Os conceitos anteriormente apontados e desenvolvidos por Cerveny (2006), referentes a "mala", "bala" e "cola" parecem não ter lugar na dinâmica e esperteza de Aninha.

Proteção é a palavra-chave. Proteção de si mesmas e proteção do casal, no sentido de preservar um espaço para a intimidade da resolução do conflito, que afinal de contas, pertence prioritariamente ao casal. Não se pode dissociar o sofrimento da criança desse ambiente confuso, no entanto, não se pode atribuir unicamente o sofrimento dela ao que se passa com o casal. Minuchin et al. (2009) assinalam que, como expressão de competência, muitas vezes a família se organiza, episodicamente, no sentido de expressar uma relação mais funcional que envolve a todos, até que as expressões individuais possam se restabelecer. Ou seja, até que cada um dos pais individualmente possa tomar decisões que favoreçam o sistema familiar como um todo e a si mesmos. Aninha: Mas depois eles saíram rápido. Porque acho que eles pensaram que eu ia contar para minha irmã. 
Nota-se, nessa fala de Aninha, preocupação e certa curiosidade com o que estaria ocorrendo entre seus pais. Ela deixa transparecer seu interesse em ser percebida para, talvez, modificarem seus estados de ânimo e mudarem o rumo da conversa de maneira a não mais brigarem. Ao verificar que "eles saíram rápido" observou que seu objetivo foi atendido: Aninha foi vista e eles, de imediato, interromperam a discussão e ela se afastou. Essa motivação denota a busca em alterar a dinâmica da relação parental na tentativa de reduzir a tensão da situação que vivenciava (triangulação). Aponta-se essa estratégia como um recurso utilizado pela criança para enfrentar o contexto familiar estressante que a ela se apresentava (Juras \& Costa, 2011a). Além disso, no desenho de Bibinha, ela e as irmãs estavam entre os pais. É porque eles estavam querendo brigar e nós três aparecemos e não deixamos eles brigarem. O "desaparecer" ou o "aparecer" perante o casal em conflito é manejado como estratégia.

Nota-se a participação ativa das crianças em meio ao jogo de relações familiares. Os filhos não são passivos na construção das relações familiares, ainda que estejam em nível hierárquico inferior aos pais. Nas situações de conflito parental, é comum os filhos serem observadores participantes, realizando movimentos de aproximar e afastar em ocasiões de maior ansiedade entre os genitores (Bowen, 1979).

\section{Apoio Mútuo dentro do Subsistema Fraternal}

O subsistema fraternal permite o desenvolvimento de relações entre iguais, ainda que possam existir hierarquias entre irmãos marcadas por idade e gênero. A fratria torna-se protetiva diante de situações em que há litígio conjugal. Os vínculos fraternos tendem a se intensificar em momentos de transição familiar e, geralmente, o primogênito é incumbido de assumir a responsabilidade pelos irmãos mais novos. Ademais, o filho mais velho tem maior tendência a ser inserido nos conflitos de lealdade parental. No entanto, ao longo do 
desenvolvimento e, dependendo das circunstâncias, a liderança pode ser alternada entre os irmãos (Britto, 2002; Juras \& Costa, 2011a; Simeón, 2000).

Bibinha: É porque um dia eles estavam brigando e a Aninha queria ir lá. Aí eu segurei ela e ela não foi. No caso em questão, observa-se que a filha primogênita se sente responsável por interferir nas brigas do casal. Por sua vez, a segunda filha, Bibinha, preferiu evitar que Aninha se envolvesse no conflito entre os pais, mantendo-a afastada do ambiente. Aninha acatou a interseção efetuada pela irmã mais nova, caracterizando uma preocupação mútua na defesa dos interesses das irmãs.

Nessa situação, pode-se considerar Aninha como filha parentalizada, no sentido de responsabilizar-se por separar a briga dos pais. Ao sentir a tensão provocada pela discussão do casal, surge um terceiro para intermediar o conflito e, assim, reequilibrar a relação e diminuir a ansiedade. Nesse caso, a filha primogênita percebe o conflito e impulsiona-se para interferir na relação agressiva entre os genitores, porém é impedida pela irmã (Bowen, 1979; Juras \& Costa, 2011a). Por outro lado, Bibinha ocupa o lugar de cuidadora das irmãs nesse momento, primeiramente se protegendo e, posteriormente, protegendo a irmã mais velha e a mais nova dos atritos entre os pais. Essa é uma estratégia de enfrentamento/superação interessante apontada por Juras e Costa (2011a), ao se referirem ao fato de a criança mais sensível ter o papel de proteger os irmãos, no intuito de afastá-los do conflito parental. Essa organização familiar é também apontada por outros autores, dentre eles, Boszormenyi-Nagy \& Spark (2008) e Britto (2002).

A cooperação fraterna obteve força para enfrentar as dificuldades comuns perante a verticalização do poder parental que estava enfraquecido aos olhos das crianças. Filhos únicos também aprendem a lidar com as situações adversas, contudo podem apresentar dificuldade em cooperar e compartilhar com terceiros (Fourez, 2000). 


\section{As expectativas quanto à resolução do conflito}

Quanto à expectativa de término das brigas e do processo judicial, Aninha e Bibinha demonstram incertezas relativas ao futuro: Entrevistadora: E quando vocês acham que o processo vai acabar? Bibinha: Como assim? Aí eu fico em dúvida. Talvez... no final do ano? Final do mês? Dois meses... Ah, não dá pra pensar... porque a situação tá grande! Entrevistadora: E as brigas, quando as brigas vão acabar? Aninha: Eu não sei exatamente... E quem é que decide quando o processo vai acabar? Aninha: O juiz? Entrevistadora: É uma possibilidade, o juiz. E você Bibinha, quem você acha que vai fazer com que o processo acabe? Bibinha: Deus nosso Pai.

A percepção de uma das crianças é que a finalização do processo judicial cabe ao juiz e não aos pais. A influência da lógica do contexto judiciário, na compreensão de crianças e adolescentes, coloca o magistrado como o detentor do poder de acabar com o processo. No caso em tela, as crianças não vinculam o término dos conflitos ao fim do processo judicial, sendo para elas, situações distintas embora reconheçam a existência de momentos familiares difíceis. Para a outra criança, o encerramento do processo compete a Deus. A crença em Deus ocorre a partir do processo gradual de socialização. O pai, ainda que não se considere católico praticante, instituiu o hábito diário da oração junto às filhas, permitindo que Deus faça parte de seu contexto de vida como solução de seus problemas (Kiesling, 2011; Walsh, 2010).

Carraro e Penso (2012) traçam um paralelo entre a magistratura e o sacerdócio, considerando que ambos são marcados pelo simbolismo do divino. A fala das crianças permite essa comparação, de juiz e Deus como únicos entes que podem finalizar o processo e, consequentemente, as brigas entre seus pais. Vale também considerar que o núcleo familiar paterno compartilha de valores religiosos de orientação católica, embora não frequentando as missas, mas fazendo orações diárias principalmente enaltecidas pelo pai e vivenciadas pelas crianças. Deus é representado como porto seguro para as crianças de pais separados. Ademais, o desenvolvimento da fé ocorre em paralelo com o fortalecimento do subsistema pai-filha. 
Denota-se ainda, que Bibinha repete o recurso religioso-cristão utilizado por seu pai como alternativa que pode solucionar o impasse que vivencia (Kiesling 2011; Walsh, 2010).

Destaca-se que ambas as formas de finalização trazidas pelas filhas não consideram os pais como competentes e responsáveis pelo término do processo. A percepção do conflito conjugal é de grande intensidade, que retira a solução do problema dos genitores, colocando nas mãos de poderes de outras instâncias superiores e externas à família. As resoluções apresentadas pelas crianças se originam do ambiente familiar a que pertencem, possivelmente a partir de respostas que já ouviram de seus pais ou de outros familiares, pois há um processo judicial em curso. Entretanto, parece que a compreensão das filhas externaliza a competência de finalização das brigas entre seus pais.

\section{Considerações Finais}

Esta pesquisa demonstrou que as crianças, mesmo pequenas, são sujeitos ativos no contexto familiar. Ainda que estejam hierarquicamente abaixo dos genitores, a participação delas é ativa em compreender a realidade familiar em que se inserem e em agir diante dessas percepções. Os sentimentos negativos diante do alto nível de conflito parental não paralisam as crianças, ao contrário, as impulsionam a desenvolverem estratégias de enfrentamento aos problemas decorrentes do divórcio, especialmente as brigas. Quando a relação entre os genitores e a criança está fortalecida, ela fica mais propensa a enfrentar de modo mais ativo e eficaz situações adversas que se apresentam ao longo de sua vida (Vélez, Wolchik, Tein \& Sandler, 2011; Walsh, 2010).

O movimento paradoxal das crianças em se aproximarem e se distanciarem do conflito parental demonstra a confusão que os filhos sentem ao se depararem com brigas entre seus pais. O paradoxo entre o sofrimento e a resiliência mostra-se presente nessas situações de litígio familiar. Os profissionais que escutam os filhos envolvidos em processos judiciais de 
Varas de Família devem atentar para esses dois aspectos complementares no desenvolvimento das crianças e dos adolescentes. É fundamental avaliar os sofrimentos dos filhos em meio ao conflito conjugal, bem como enfatizar os recursos que eles desenvolvem ao longo de sua vivência familiar e social.

Ao destacar o subsistema fraterno, tenciona-se dar visibilidade às crianças no intuito de que o profissional avaliador vá além do conflito apresentado pelo ex-casal, a fim de evitar reconhecer a criança apenas como vítima da interação familiar e culpabilizar/responsabilizar os pais por isso. No exemplo aqui trazido, a fratria se mostrou competente no enfrentamento das situações adversas que se apresentavam na família naquele momento, o que confirma os resultados das pesquisas realizadas por vários investigadores nessa área conforme mencionado no presente artigo. Isso demonstra que os pais, no exercício da parentalidade conseguiram, de algum modo, agir com competência na condução da educação e na transmissão de valores que preservaram as filhas do contexto conjugal conflituoso que se manteve mesmo após a separação.

O fortalecimento da fratria por meio da união e da cooperação entre as irmãs revelaram-se úteis no confuso contexto familiar que se apresentava diante delas. Mudanças na organização das relações familiares, até a concretização do divórcio legal e emocional eram necessárias por parte dos pais para que as crianças se sentissem protegidas e seguras a despeito das divergências conjugais.

A interação entre as irmãs retrata o que elas apreenderam no convívio familiar antes e após a separação conjugal, mesmo tendo presenciado conflitos entre seus pais. Nesse âmbito, fica evidenciada a competência parental no fortalecimento na fratria. $\mathrm{O}$ que se quer pôr em relevo são os pontos positivos, as novas perspectivas para a família, pois no momento em que busca a Justiça, considera-se incompetente para decidir sobre como conduzir a educação dos filhos, já que na compreensão de seus participantes, "faliram" no quesito conjugalidade. No 
caso da família aqui apresentada, destacam-se as estratégias que o grupo fraterno utiliza para enfrentar o conflito existente entre os pais.

Outras perspectivas podem ser apontadas a fim de encorajar a família a explorar diferenças demonstrando a capacidade que cada componente tem de cuidar-se e de curar-se uns aos outros (Minuchin, 1985; Minuchin, Lee, \& Simon, 2008; Minuchin et al. 2009). Apontar aspectos que demonstrem novas perspectivas para a ampliação do padrão relacional no qual a família se encontra aprisionada quando busca a Justiça, poderá contribuir para a crença em suas potencialidades e na recorrência de novas alternativas de soluções para o atendimento de suas necessidades e sobrevivência saudável da nova organização do grupo familiar.

Os recursos encontrados pelas crianças devem ser objeto de análise durante a avaliação psicossocial. Para tanto, o profissional avaliador ao estar atento à dinâmica familiar, deve pontuar aos participantes a compreensão do padrão relacional observado e indicar caminhos que a nova organização da família descasada poderá seguir a fim de evitarem que a sobrecarga emocional recaia sobre os filhos. Desse modo, é importante destacar para os pais a necessidade de valorizarem as atitudes de independência que cada criança manifestar a fim de estimular o desenvolvimento de autonomias (Guanga, 2010).

No âmbito das recomendações psicossociais ao juiz solicitante da avaliação, estas devem pautar-se nas reflexões efetuadas com a família, particularmente, com os pais, também considerando a proteção e a segurança das crianças, evidenciando as potencialidades de cada um e de cada subsistema na condução da trajetória familiar conjugalmente divorciada. Assim sendo, o profissional avaliador contribuirá de modo substancial quando, ao confeccionar o parecer técnico para o juiz demandante, indicar as circunstâncias do padrão relacional em que a família se encontra e efetuar a sinalização das dificuldades e competências observadas nos subsistemas ao se estudar a interação familiar no decorrer da avaliação psicossocial. Com 
isso, o Estado estará cumprindo seu papel, no intuito de resguardar a proteção da criança no atendimento aos seus interesses conforme enfatiza a Convenção sobre os Direitos da Criança (UNICEF, 1990). 


\title{
ARTIGO EMPÍRICO 1 DA PESQUISA
}

\section{“Um Coração Partido": O Sofrimento da Criança em Disputas de Guarda}

\author{
Marcia Regina Ribeiro dos Santos \\ Liana Fortunato Costa
}

\section{Resumo}

Este artigo objetivou analisar, com base nos resultados de uma pesquisa qualitativa, como a criança expressou seu sofrimento durante avaliação psicossocial no contexto da Justiça em situação de conflito familiar, quando os pais estão separados/divorciados e disputam a sua guarda e regulamentação de visita. Participaram 11 crianças com idades entre 8 e 11 anos. A interpretação das informações resultou em três núcleos de sentido, aos quais atribuíram-se significados para a discussão: sentimentos que expressam o sofrimento, origem do sofrimento e a superação do sofrimento. Os resultados mostraram que, nesse contexto, a criança identifica sentir tristeza, solidão, agonia, angústia, saudade, amor e raiva, percebendo não ser vista pelos pais mediante a permanência do conflito parental, de onde reconhece proceder o seu sofrimento. Em sua expressão, a criança se mostra emocionalmente dividida, conseguindo apontar soluções que a acalme e sentindo-se segura ao ter a garantia de que será respeitada no atendimento de seus anseios.

Palavras-chave: Sofrimento da criança, conflito parental, separação parental, disputa de guarda, avaliação psicossocial 


\title{
“A Broken Heart": The Suffering of Children in Custody Disputes
}

\begin{abstract}
The present article aims to analyze how children express their suffering during psychosocial evaluation, in the judicial context, due to family conflicts, when parents are separated/divorced and dispute their custody and visit schedules, according to results from a qualitative research. Eleven children between 8 and 11 years old participated in the experiment. Information interpretation resulted in three units of meaning, each one of them assigned meanings to be discussed: feelings that express suffering, their origin and overcoming. Results show that within this context, children recognize by sensing themselves invisible as the parental conflict - they recognize it as origin of their suffering - remains. Children showed, in their expression, to be emotionally divided and able to point out solutions to calm them down and feel safe, as they ensure they will be respected in the attendance of their expectations.
\end{abstract}

Keywords: Children suffering, parental conflict, parental separation, custody dispute, psychosocial evaluation.

\section{“Un Corazón Partido": EI Sufrimiento del Niño en Disputas de Guarda}

\section{Resumen}

Este artículo objetivó analizar, basado en los resultados de una investigación cualitativa, como el niño expresó su sufrimiento durante evaluación psicosocial en el contexto de la justicia en situación de conflicto familiar, cuando los padres están separados/divorciados y disputan su guarda y regulación de visita. Participaron 11 niños con edades entre 8 y 11 años. La interpretación de las informaciones resultó en tres núcleos de sentido, a los cuales se atribuyó significados para la discusión: sentimientos que expresan el sufrimiento, origen del sufrimiento y la superación del sufrimiento. Los resultados enseñaron que, en ese contexto, el 
niño identifica sentir tristeza, soledad, agonía, angustia, nostalgia, amor y rabia, percibiéndose invisible ante la permanencia del conflicto parental, de donde reconoce proceder su sufrimiento. En su expresión, el niño se muestra emocionalmente dividido, logra apuntar soluciones que lo tranquilice y se siente seguro al tener la garantía de que será respetado en la atención de sus anhelos.

Palabras clave: Sufrimiento del niño, conflicto parental, separación parental, disputa de guarda, evaluación psicosocial

A separação conjugal é uma realidade contemporânea (Amato, 2014; Ashbourne, Whitehead, \& Hawkins, 2013; Féres-Carneiro, 2003; Gonçalves, 2010), bem como recasamentos e separações repetidas (McNamee, Amato, \& King, 2014). A separação conjugal gera estresse, com grande custo emocional, em razão das mudanças a que todos os envolvidos estão sujeitos e, principalmente, quando há intenso conflito interparental (Cashmore \& Parkinson, 2011; Juras \& Costa, 2011a; Stover, 2013). Nesses casos, a separação, ao abranger filhos e, em especial, quando estes são pequenos, pode causar prejuízos emocionais que, não sendo superados, podem afetar a saúde mental deles e prolongar o seu sofrimento até a vida adulta (Baker \& Brassard, 2013; Cohen \& Levite, 2011; Lehrmann, 2010; Lucas, Nicholson, \& Erbas, 2013).

Quando a relação parental envolve conflito intenso, a criança, ao vivenciar a separação dos pais, sofre não pela separação em si, mas pelas contendas que presencia, sendo o sofrimento agravado quando essas demandas se perpetuam mesmo após o rompimento da relação dos progenitores (Elrod, 2010; Lamela, Castro, \& Figueiredo, 2010; Johnston, Roseby, \& Kuehnle, 2009; Nunes-Costa, Lamela, \& Figueiredo, 2009; Pereira \& Matos, 2008; Raposo et al., 2011; Shienvold, 2011). Entretanto, as reações de cada componente da 
família variam pois dependem dos aspectos emocionais e das circunstâncias pós-divórcio que se lhes apresentam (Amato, 2014). Nas crianças, mais especificamente, as reações podem envolver raiva, ansiedade ou luto, com intensidades variáveis (Johnston, Roseby, \& Kuehnle, 2009; Pereira \& Matos, 2008; Shienvold, 2011).

De acordo com Pereira e Matos (2008), as crianças em idade escolar, entre 6 e 11 anos, podem experimentar dor ou ansiedade pela separação, sentem falta da família intacta, vivenciam luto e sentimento de revolta, de irritação, de impotência. Segundo Shienvold (2011), as crianças tendem a fazer escolhas em apoio a um dos pais, repetindo comportamentos inadequados do pai ou mãe com quem está aliada, podendo se sentir muito empoderada em seus comportamentos inapropriados e agir contra quem tenta desafiar sua compreensão (pai/mãe ou outro adulto), e até comprometendo o rendimento escolar. Conforme aponta Sthal (2011), crianças em idade entre 6 e 12 anos podem experienciar tristeza e choro com desejo de retorno da família intacta. Crianças mais velhas podem sentir raiva e buscam melhorar a autoestima. Frequentemente, sentem-se responsáveis pela separação/divórcio, principalmente se percebem que o conflito está focado nelas. Muitas crianças podem expressar múltiplos sintomas, tais como regressão, problemas de sono, acting out, problemas de comportamento e baixo rendimento escolar, agressão contra os colegas e depressão. Ainda de acordo com esse autor, algumas crianças acreditam em justiça e querem agradar os pais. Sentem-se emocionalmente sobrecarregadas pelos conflitos interparentais. Quando pai ou mãe está deprimido(a), as crianças correm o risco de serem parentalizadas para cuidar deles. Além disso, conforme Sthal (2011), há crianças que, ao vivenciarem conflito intenso, mostram-se superficialmente bem, mas sentem-se oprimidas e vulneráveis interiormente, aprisionadas ao conflito devido à lealdade e preocupando-se com ambos os pais. 
Logo, a observância de como a criança vive, sente e pensa o período de mudanças pelo qual está passando, que pode envolver conflito parental em diferentes intensidades, significa compreender o sofrimento expresso por ela. Simultaneamente, importa considerar os elementos que ela destaca quanto à competência do pai e da mãe no exercício da parentalidade, bem como a interação dela com ambos os pais. Desse modo, a observação dos sentimentos e percepções vivenciados pela criança e expressos por ela nesse âmbito, permite que o julgador esteja mais próximo de sua realidade, viabilizando os acordos e facilitando o cumprimento da decisão (Santa Rosa, Corte Real, \& Vieira, 2013). Embora as definições judiciais sejam influenciadas pelos seus direitos e pelas necessárias e urgentes mudanças na organização familiar, o impacto transcorrerá na gerência das interações no cotidiano da família (Holtzman, 2011), que tem competência para administrá-las (Ausloos, 1996).

Partindo dessas reflexões, este artigo objetivou analisar como a criança expressa o seu sofrimento durante avaliação psicossocial no contexto da Justiça em situação de conflito familiar, quando os pais, que estão separados/divorciados, disputam a sua guarda e a regulamentação de visita.

\section{Método}

A presente investigação pautou-se na pesquisa qualitativa, que utiliza a interpretação como fundamento (Bauer, Gaskell, \& Allum, 2010; Flick, 2009). Sem perder de vista as interações familiares, a pesquisa aqui relatada privilegiou a entrevista apenas com a criança. Assim, a análise parte do olhar que ela traz do contexto familiar, observado no momento da avaliação psicossocial durante o trâmite do processo de disputa de sua guarda e regulamentação de visita na Justiça. As informações foram obtidas no decorrer da realização do estudo psicossocial, do qual emergiu o tema estudado, seguido da análise e interpretação 
do significado dessas informações, produzindo-se novos conhecimentos (Creswell, 2010; Flick, 2009).

\section{Contexto}

A pesquisa ocorreu no Tribunal de Justiça do Distrito Federal e dos Territórios (TJDFT), que contempla a Secretaria Psicossocial Judiciária (SEPSI), subdividida em duas Subsecretarias, sendo que uma delas é responsável pelo Serviço de Assessoramento às Varas Cíveis e de Família (SERAF). Esse serviço atende pessoas oriundas de varas de família, encaminhadas pelo juiz, e é composto por assistentes sociais e psicólogos. As informações para a pesquisa foram colhidas durante o processo habitual de avaliação psicossocial realizado no SERAF que incluiu o acolhimento individual da criança em disputa.

\section{Participantes}

O principal indicativo para a seleção dos casos para a pesquisa foi o fato de a dinâmica familiar evidenciar intenso conflito, crônico ou não, principalmente entre o par parental (Johnston, et al., 2009). Os participantes da pesquisa foram 11 crianças pertencentes a nove famílias, com idades que variaram entre 8 e 11 anos. Para melhor entendimento, as informações relativas à qualificação das crianças estão descritas na tabela 1, a seguir. 


\section{Tabela 1}

Informações das Crianças Participantes da Pesquisa e da Ação Judicial por Família

\begin{tabular}{|c|c|c|c|c|c|c|c|c|}
\hline \multirow[b]{2}{*}{$\begin{array}{l}\text { Famí- } \\
\text { lia }\end{array}$} & \multicolumn{4}{|c|}{ Informações sobre as crianças } & \multicolumn{4}{|c|}{ Ação judicial } \\
\hline & Nome & $\begin{array}{l}\text { Idade/ } \\
\text { sexo }\end{array}$ & $\begin{array}{l}\text { Ano } \\
\text { esco- } \\
\text { lar }\end{array}$ & $\begin{array}{l}\text { Reside } \\
\text { com }\end{array}$ & Tipo & $\begin{array}{l}\text { Movida } \\
\text { por }\end{array}$ & Contra & Motivo \\
\hline F1 & Jaspe & $\begin{array}{l}11 / \\
M\end{array}$ & $6^{\circ}$ & $\begin{array}{l}\text { Pai e } \\
\text { Irmã (13 } \\
\text { anos) }\end{array}$ & RDUE & Pai & Mãe & $\begin{array}{l}\text { Violência } \\
\text { interparental, } \\
\text { uso abusivo de }\end{array}$ \\
\hline & Ônix & $\begin{array}{l}8 / \\
M\end{array}$ & $3^{\circ}$ & $\begin{array}{l}\text { Mãe e } \\
\text { irmã (4 } \\
\text { anos) }\end{array}$ & & & & $\begin{array}{l}\text { álcool e } \\
\text { negligência dos } \\
\text { filhos. }\end{array}$ \\
\hline F2 & Jasmim & $\begin{array}{l}9 / \\
\mathrm{F}\end{array}$ & $3^{\circ}$ & $\begin{array}{l}\text { Mãe e } \\
\text { irmão } \\
(13 \\
\text { anos) }\end{array}$ & GR & Mãe & Pai & $\begin{array}{l}\text { Mãe suspeita de } \\
\text { abuso sexual da } \\
\text { filha na casa } \\
\text { paterna por } \\
\text { enteados. }\end{array}$ \\
\hline F3 & Ágata & $\begin{array}{l}10 / \\
\mathrm{F}\end{array}$ & $5^{\circ}$ & $\begin{array}{l}\text { Mãe e } \\
\text { avós } \\
\text { mater- } \\
\text { nos }\end{array}$ & RV & $\begin{array}{l}\text { Avós } \\
\text { paternos }\end{array}$ & Mãe & $\begin{array}{l}\text { Visitas do pai à } \\
\text { filha suspensas } \\
\text { judicialmente } \\
\text { por abuso } \\
\text { sexual } \\
\text { comprovado. }\end{array}$ \\
\hline F4 & Mirtilo & $\begin{array}{l}9 / \\
\mathrm{M}\end{array}$ & $3^{\circ}$ & $\begin{array}{l}\text { Mãe, } \\
\text { compa- } \\
\text { nheiro e } \\
\text { um } \\
\text { irmão } \\
\text { unilate- } \\
\text { ral (6 } \\
\text { anos) }\end{array}$ & $\mathrm{AG}$ & $\begin{array}{l}\text { Avós } \\
\text { maternos } \\
\text { mãe e pai }\end{array}$ & Não há & $\begin{array}{l}\text { Benefícios em } \\
\text { plano de saúde } \\
\text { e bolsa de } \\
\text { estudos para } \\
\text { língua } \\
\text { estrangeira. }\end{array}$ \\
\hline F5 & Berilo & $\begin{array}{l}8 / \\
M\end{array}$ & $2^{o}$ & $\begin{array}{l}\text { Mãe e } \\
\text { irmã (14 } \\
\text { anos) }\end{array}$ & $\mathrm{RV}$ & $\begin{array}{l}\text { Avó } \\
\text { paterna }\end{array}$ & Mãe & $\begin{array}{l}\text { Pai falecido } \\
\text { após a } \\
\text { separação } \\
\text { conflituosa. }\end{array}$ \\
\hline F6 & Yacón & $\begin{array}{l}9 / \\
\mathrm{M}\end{array}$ & $4^{o}$ & $\begin{array}{l}\text { Pai e } \\
\text { compa- } \\
\text { nheira }\end{array}$ & RV & Pai & Mãe & $\begin{array}{l}\text { Acusação de } \\
\text { maus tratos } \\
\text { físicos e } \\
\text { psicológicos } \\
\text { durante as } \\
\text { visitas na casa } \\
\text { materna. }\end{array}$ \\
\hline F7 & $\begin{array}{l}\text { Esme- } \\
\text { ralda }\end{array}$ & $\begin{array}{l}10 / \\
\mathrm{F}\end{array}$ & $5^{\circ}$ & $\begin{array}{l}\text { Mãe, } \\
\text { avó e tio } \\
\text { mater- } \\
\text { nos }\end{array}$ & $\mathrm{RV}$ & Mãe & Pai & $\begin{array}{l}\text { Pedido de } \\
\text { suspensão das } \\
\text { visitas por } \\
\text { acusação de } \\
\text { abuso sexual } \\
\text { pelo pai e }\end{array}$ \\
\hline
\end{tabular}




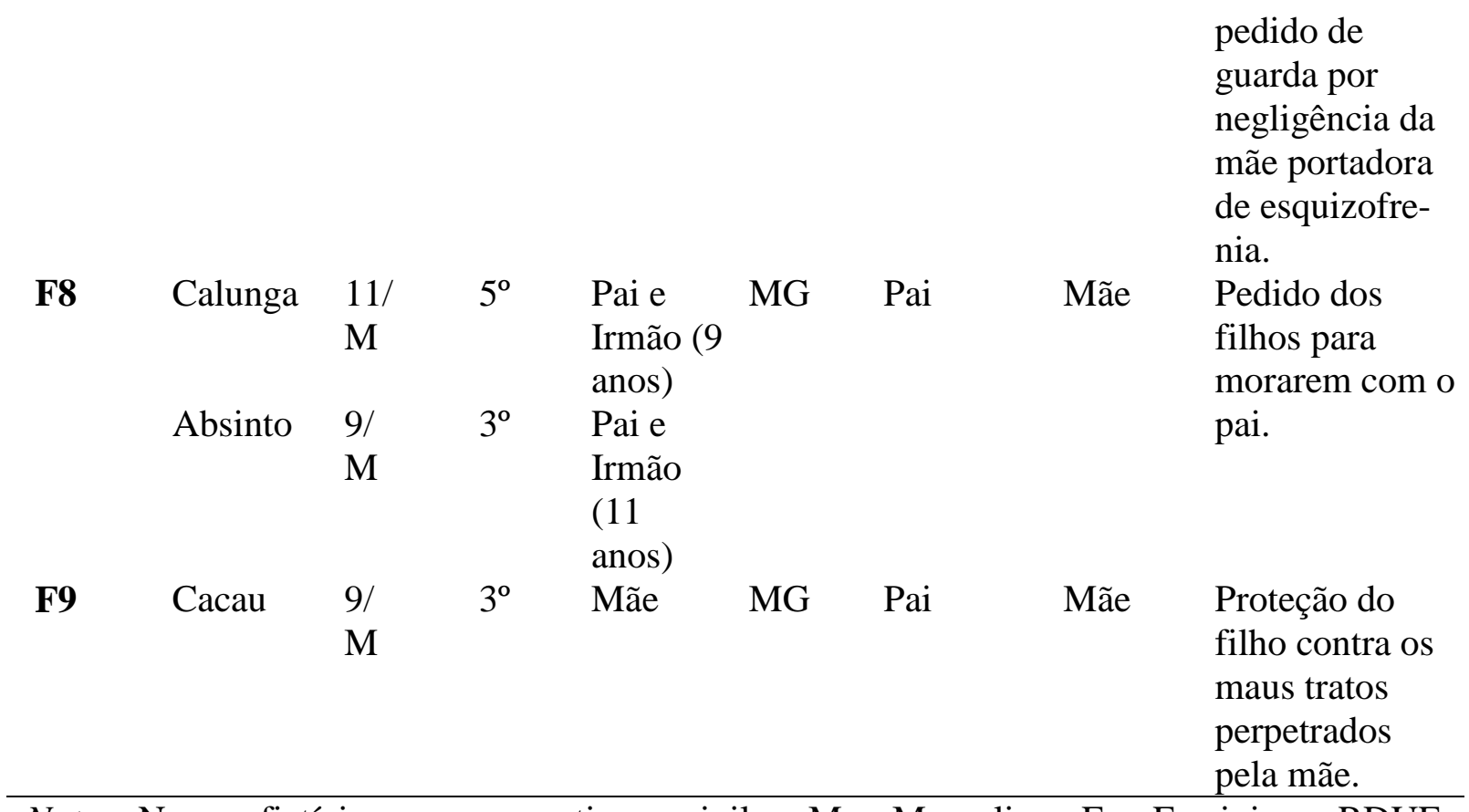

Nota: Nome fictício para garantir o sigilo. $\mathrm{M}=$ Masculino $\mathrm{F}=$ Feminino; $\mathrm{RDUE}=$ Reconhecimento e Dissolução de União Estável; GR= Guarda e Responsabilidade; AG= Acordo de Guarda; RV= Regulamentação de Visita; MG= Modificação de Guarda.

\section{Instrumentos}

Os instrumentos utilizados foram os processos judiciais, as pastas onde são registradas as informações das famílias e os pareceres técnicos efetuados pelos profissionais responsáveis pela avaliação psicossocial. Para obter as informações, utilizou-se um roteiro, previamente elaborado, que serviu para guiar a entrevista com a criança. Esse roteiro englobou os seguintes aspectos com ênfase na percepção da criança: o motivo de estar na Justiça, as histórias contadas concernentes às suas percepções e vivências no contexto familiar e as concepções sobre o seu sofrimento. O outro instrumento utilizado para a obtenção de informações sobre as expressões da criança, foi o desenho, conforme propõe Puviani (2011). Desse modo, mediante solicitação de uma das pesquisadoras que conduziu a entrevista individual, a criança poderia representar suas vivências referentes ao conflito familiar ensejado pela ação judicial. Assim, pediu-se que, em uma folha em branco, ela desenhasse as suas preocupações e, posteriormente, fizesse outro desenho, representando as soluções em relação às preocupações apontadas. A execução do desenho, tanto em relação às preocupações 
quanto às soluções, poderia requerer, por parte da criança, mais de uma folha de papel em branco. Além disso, na consigna para a confecção do desenho, sugeriu-se que fosse feito de duas maneiras. Uma delas seria representar as imagens que lhe viessem à mente e, a outra, que a criança se inspirasse nos elementos que compõem a natureza, a partir dos reinos mineral, vegetal e animal. Isso poderia ampliar suas ideias, permitindo a livre expressão de sua criatividade. O desenho torna visível o mundo interno que está obscuro, relacionando-o com o exterior na comunicação de emoções. Desse modo, o desenho é visto como autorrevelação, integrando o verbal e o não verbal (Puviani, 2011).

\section{Procedimentos}

As salas onde as entrevistas foram realizadas estavam equipadas com material lúdico (jogos e brinquedos), folhas de papel em branco, lápis preto $\mathrm{n}^{\mathrm{o}} 2$ e coloridos, giz de cera, além de material de apoio (cadeiras e mesa) com as medidas apropriadas para a criança. A obtenção das informações para a pesquisa ocorreu durante os meses de novembro e dezembro de 2013. O registro dessas informações foi efetuado por meio da leitura de cada processo. Cada atendimento realizado pelos profissionais nas variações dos subsistemas familiares durou em média, uma hora e meia, incluindo visitas às escolas e às residências, quando o caso requeria. As entrevistas, com cada criança, ocorreram no decorrer da avaliação efetuada pelos profissionais e tiveram a duração aproximada de 40 minutos e foram gravadas em áudio e posteriormente transcritas. O conteúdo foi analisado na modalidade temática apontada por Minayo (2014) em que se obteve núcleos de sentido, aos quais foram atribuídos significados, denominados de subnúcleos.

\section{Cuidados Éticos}

Para a realização da pesquisa, o projeto foi submetido ao Comitê de Ética em Pesquisa conforme resolução do CFP 016/2000 em que a aprovação incluiu o termo de compromisso pelo responsável do Tribunal de Justiça e os Termos de Consentimento Livre e 
Esclarecido (TCLE) para o responsável da(s) criança(s) e o Termo de Assentimento na forma oral, para que a criança pudesse participar livremente da pesquisa.

\section{Resultados e Discussão}

A partir da análise das informações coletadas em relação à expressão da criança, destacaram-se três núcleos de sentido: 1 . Sentimentos que expressam o sofrimento, 2. Origem do sofrimento, 3. A superação do sofrimento.

\section{“Um Coração Partido": Sentimentos que Expressam o Sofrimento}

Neste núcleo, quatro crianças verbalizaram claramente seus sentimentos. A tristeza é apontada como sofrimento, relacionando, em seguida, a solidão, a raiva, a agonia, a angústia, a saudade e o amor. Jasmim: Me sinto triste...angústia... trauma... sentia triste... amor pelos meus pais! Cacau: Muito ruim... raiva... [por]que os dois estavam brigando. Ágata: Eu sinto agonia... porque... eu tenho muita saudade dos meus avós! Tem um tempão que não vejo eles... saudade mesmo! Berilo: Porque ás vezes a minha mãe não fica falando muito com a minha vó (paterna), minha... minha vó às vezes fala com a minha mãe, a minha mãe não fica nem aí! Eu sei que eu tô muito sozinho, triste às vezes eu fico. Esses sentimentos são destacados por crianças de igual faixa etária às estudadas por Pereira e Matos (2008) e por Shienvold (2011). Observa-se haver variações na intensidade do sofrimento apontado pelas crianças, pois depende da interação entre as suas características individuais, tais como capacidade de superação das dificuldades e habilidades sociais e a dinâmica relacional familiar em relação à prática parental (enfraquecimento nos laços entre pais e filhos) na qual está inserida (Amato, 2014). Além do sofrimento concernente aos conflitos interparentais, Ágata e Berilo destacaram que tais conflitos se estendem à família ampliada, repercutindo em dificuldades para as crianças na ausência de contato com os familiares do pai não residente. 
Para a criança, é importante a garantia do convívio com a família extensa, em especial, com os avós. Isso assegura a continuidade da vinculação com o genitor com o qual os contatos são inexistentes (Cardoso \& Costa, 2014), tendo em vista o motivo da ação judicial.

Três outras crianças, Calunga, Absinto e Jaspe, evidenciaram o sofrimento a partir dos conflitos parentais, porém de modo indireto; Calunga: Então, porque ela mandou "nóis" para Nordeste se está com saudade? Absinto: Pra ver nossos avós (maternos) e pra ficar mais distante do nosso pai. Jaspe: Não... eu não gosto dela quando ela está bebendo. Não gosto nem de ir lá! É por causa que meu pai... Mirtilo e Yacón evidenciaram sofrimento a partir de ações de seus pais direcionadas a eles, que têm origem nas desavenças interparentais, perpassando o processo de separação/divórcio e após esse evento. Mirtilo: Mal. (referindo-se ao descumprimento da promessa do pai em buscá-lo na casa materna). Yacón: Quando minha mãe me deixa de castigo (sente tristeza), pois reconhece que o motivo que o levou à Justiça envolve conflito entre seus pais e, ao mesmo tempo, o envolve porque se percebe como parte integrante desse contexto.

Os desenhos foram utilizados como recurso para tornar visíveis, por meio de imagens, os sentimentos da criança, tornando mais claro o sofrimento que está verbalizando, o que oportuniza a transformação de sua história e possibilita a criação de novos contextos interacionais (Puviani, 2011). A criança, por meio do desenho, expressa seus estados de ânimo e assinala os conflitos experienciados na família, fornecendo elementos para análise e intervenção em seu ambiente familiar e social (Andolfi, 2013). Assim sendo, por não ser possível incluí-los neste texto, optou-se por descrevê-los, bem como as falas deles decorrentes.

Para exemplificar, aqui serão tratados os desenhos feitos por Jasmim (Anexos 16A, 17B e 18C ) em preto e branco. Os coloridos (Anexos 32A, 33B e 34C) não serão analisados, por falta de espaço neste artigo. Ela representou, na primeira folha, suas preocupações em 
preto e branco: Um coração partido. (...) Meu! Eles [os pais], (o partiram), com essa briga! E [também o] dos meus irmãos! As duas partes do coração estão distanciadas uma da outra e lembram duas cabeças, que são representadas em seguida (Anexo 17B e 18C). No desenho (Anexo 16A), o corte, que representa a separação dos pais parece ter sido feito com uma serra, com borda saliente e pontiaguda. Desse modo, ela representa a raiva que percebe haver no conflito parental, a qual também está contida nela, em seu coração. É assim que ela se sente e se percebe em sofrimento: emocionalmente dividida entre amor e raiva. Ela não sabe qual rumo seguir, pois divide-se em atender a si, ou aos pais. Busca ser reconhecida, expressando o amor que sente por ambos, apesar do conflito que percebe existir entre eles. Espera ser vista e considerada pelos pais e que seu amor supere o conflito. Nos desenhos representando as soluções (Anexo 19A e 20B), Jasmim utilizou duas folhas de papel. Ao concluir a primeira folha (19A), Jasmim disse: Amizade [entre] minha mãe e meu pai. A solução apresentada por ela está representada por duas mãos que tentam se encontrar para um aperto de modo a finalizarem as brigas e tornarem-se amigos. Dessa maneira, ela conseguiu sair do sofrimento (amor e raiva) que paralisa, para a ação, pois as mãos simbolizam o fazer, encontrando-se em um contato amigável, apaziguando seu mundo interno (Puviani, 2011). Com isso, a criança estabeleceu um encontro consigo mesma, em relação aos dois lados dentro de si e que conflitavam naquele momento. No segundo desenho da solução, (Anexo 20B), escreve o seu sentimento em relação aos seus pais: “Amor por meus pais”. No coração, Jasmim associa a separação ao conflito. Ela destaca que apesar de os pais estarem separados, o conflito está mantido, gerando-lhe sofrimento (Lucas et al., 2013; Pereira \& Matos, 2008; Raposo et al., 2011), o qual perdura por anos após a separação/divórcio, e pode prejudicar o seu desenvolvimento (Nunes-Costa et al., 2009). Jasmim destacou, no decorrer da entrevista: $E u$ estava dentro da barriga [da mãe] quando o meu pai saiu de casa. Ela estava com 9 anos e sua guarda, bem como a de seus irmãos mais velhos, estava em disputa naquele momento. 
Com o oferecimento de espaço para sua expressão, Jasmim pôde sentir-se acolhida, revelando um contexto familiar que lhe causa angústia, trauma e divisão de sentimentos, pois compreende depender dos pais para sua sobrevivência e, ao mesmo tempo, reconhece necessitar desenvolver sua autonomia (Minuchin, 1990; Minuchin, Nichols, \& Lee, 2009; Santa Rosa et al., 2013), em um contexto em que se sente desafiada a superar seu sofrimento.

Assim, conforme apontado pelas crianças participantes da pesquisa nesse núcleo dos resultados, o sofrimento gerado pela manutenção do conflito familiar antes, durante e após a separação/divórcio, corrobora estudos vigentes na literatura (Cashmore \& Parkinson, 2011; Juras \& Costa, 2011a; Stover, 2013), a qual indica claramente os sentimentos por elas nomeados, evidenciando que a saúde mental das crianças pode ser afetada e, inclusive, atingir a idade adulta (Baker \& Brassard, 2013; Cohen \& Levite, 2011; Lehrmann, 2010; Lucas et al., 2013), especialmente se o conflito for intenso e crônico (Johnston, et al., 2009). Desse modo, compreende-se que a criança, no contexto de disputa de guarda, revela-se protagonista no sistema familiar, na interface com o sistema judicial, no momento em que é avaliada, ocasião em que se expressa autenticamente, e aguarda a decisão do juiz, pois acredita que será atendida em suas necessidades de proteção e segurança, a despeito dos diferentes pontos de vista apresentados por seus pais nesse contexto de beligerância (Santos, 2014).

\section{“O que Eu Fiz de Errado"? Origem do Sofrimento}

Neste núcleo, nove crianças entrevistadas conseguiram identificar a origem do sofrimento a partir de suas vivências. Ágata: Para mim sofrimento é quando a pessoa, vamos supor, ela queria uma coisa, mas ela não pode. (...) Mais ou menos isso... Berilo: É quando uma pessoa tem uma perda, ela sofre. (...) Tipo, a pessoa morre, uma pessoa que eu muito gosto, ela não vem mais (refere-se ao falecimento do pai). Esmeralda: Quando está acontecendo alguma coisa [de] ruim com a pessoa. Quando, tipo que, acho que não quero 
mais você aí! É tipo uma... eu queria ficar com ele. Por que ele me mandou embora? O que que eu fiz de errado? Cacau: Os dois [pai e mãe] brigando! Calunga: Uma pessoa que, por exemplo, uma pessoa que perde uma pessoa que mais ama na vida, aí fica chorando, fica triste, fica preocupado. Jasmim: Ser infeliz! Jaspe: Sofrer é tipo... alguém estar sendo maltratado, sendo judiado por alguém! Ônix: É uma pessoa que sofre muito. É a pessoa que passa por essas coisas. (...) Essas coisas que nem eu estou passando agora! (Ele chora convulsivamente). Yacón: Quando a pessoa que ela ama, uma, um... não gosta, não gosta da pessoa, que ela, aí faz ela sofrer. (...) Ou quando a pessoa foi magoada!

Neste núcleo, as crianças se referem à perda, ou rompimento do convívio que gera separação permeada por conflito, confirmando que o sofrimento delas está relacionado à manutenção das desavenças interparentais (Lucas et al., 2013; Pereira \& Matos, 2008; Raposo et al., 2011), extensivas à família ampliada. Conforme Johnston et al. (2009), as crianças, na faixa etária entre 6 e 12 anos, esforçam-se para se mostrarem amáveis, boas e competentes. Desse modo, quando a criança se pergunta o que fez de errado por estar separada de um dos pais, o sofrimento está relacionado a não ser aceita como ela é, resultando em negligência e maus-tratos, apesar do esforço em desenvolver sua autoestima e confiança. Para tanto, necessita de apoio dos pais, contudo, eles estão ocupados com o conflito, que pode ser agravado se for crônico.

Para ilustrar a utilização do desenho a partir dos elementos da natureza, apresenta-se a produção efetuada por Yacón (Anexos 24A e 25B). Ao representar a sua preocupação, a criança apontando o desenho (Anexo 24A), explicou: Minha mãe seria uma... uma planta carnívora. Meu pai seria uma erva venenosa... (...) Eu seria um peixe. A história: Eles estavam discutindo. (...) Eu achava ruim. [O peixe pedia] Que os dois parassem de brigar! [O peixe pensava] Que eles estavam no tribunal. (...) Yacón segue desenhando o problema (Anexo 25B). Vou fazer um rio!(...) Fiz estranho o tubarão! Tinham várias coisas... uma 
baleia... tinha um... um peixe espada, lá na água, lá no meio! [O peixe pensava] Eu não sei qual é a verdade! (...) Saber quem... foi que me bateu? (...) Yacón faz o terceiro desenho representando a solução (Anexo 26C). Vou fazer o redemoinho! (...) [Saber a verdade] Ele [o peixe] nunca ia ter... (...) É verdade! [Assim, o peixe foi] Deixando... e esquecer tudo. E levar a minha vida normal! Fim!

Inicialmente, Yacón, ao descrever cada componente da família, apresenta e qualifica os diferentes papéis: os pais são semelhantes em sua origem, pois são plantas, porém trazem diferenças em suas funções: uma morde e, a outra, possui veneno. Em seguida, revela a dinâmica conflituosa e faz um pedido de ajuda, aproveitando o momento da avaliação: os dois precisam parar de brigar e o tribunal vai favorecer a interrupção das contendas. A criança, que aqui se descreve como peixe, é um ser livre, declarando-se não estar, portanto, aprisionada, nem fixa em um local, conseguindo se deslocar em diferentes direções. A sua movimentação evidencia sua interdependência com as plantas/pais, apontando sua vontade naquele momento, (Santa Rosa et al., 2013) pela busca de mudanças do contexto que lhe traz sofrimento. Todavia, as plantas/pais, que deveriam nutrí-la, sustentá-la, protegê-la, estão aprisionados em suas posições de conflito, com suas armas (veneno e dentes pontiagudos). O peixe/criança, por conseguir movimentar-se, deslocar-se, com seu próprio ritmo, revela-se na busca do desenvolvimento de sua autonomia e no aprendizado em lidar com a interdependência (Minuchin, 1990; Minuchin et al., 2009; Santa Rosa et al., 2013). Ao fazer a representação, por meio dos desenhos, Yacón conseguiu externar seus pensamentos e sentimentos na folha em branco, que simbolizou o seu espaço psíquico, preenchendo-a com os seus traçados. A criança transformou sua preocupação, seu sofrimento, apresentando uma solução, por meio de imagem, que o satisfez pois respondeu a sua angústia (Puviani, 2011). A internalização, em Yacón, do senso de certo e errado, própria dessa faixa etária, (Johnston et al., 2009), foi representada na busca pela verdade sobre um ponto discordante entre os pais: 
quem teria batido nele (pai ou mãe) quando tinha cerca de quatro anos de idade. Esclareça-se que essa informação não constava no processo judicial, tendo sido fornecida pela criança durante a entrevista. O peixe pode ser entendido como o símbolo da fecundidade e da vida, produto diferente da planta carnívora e da erva venenosa, e buscava a união dentro de si mesmo, a partir do seu senso de justiça. A criança consegue finalizar o processo dentro de si mesma, integrando-se na sua busca pela verdade, a sua própria verdade que foi suficiente para acalmá-la naquele momento. Yacón, a despeito de seu sofrimento, expressa sua capacidade de produzir algo novo para si, pois estava em busca de uma saída justa para o impasse em que se encontrava (Johnston et al.; Sthal, 2011).

Assim, este núcleo apontou que a criança, no desenvolvimento do seu senso de justiça (Johnston et al., 2009), ao se perguntar o que teria feito de errado para não mais ter o convívio com o pai, acredita que grande parte dos conflitos refere-se a ela, sentindo-se, por isso, responsável (Amato, 2014). Desse modo, a criança não compreende que o contexto beligerante em relação à disputa de sua guarda seja referente à separação/divórcio de seus pais, a qual não foi emocionalmente resolvida por eles (Andolfi, 2013). Para ela, o mais importante é assegurar-se de que não será abandonada (Minuchin, 1990), conforme revela Yacón, à mercê das ameaças de outros seres aquáticos, maiores do que ele, e em meio a um redemoinho de sentimentos tais como, medo, raiva, ansiedade pois sua expectativa é de que terá a garantia do amor dos pais, beneficiando-se quando eles conseguem exercer a coparentalidade de modo a atender suas necessidades biopsicossociais (Amato, 2014).

\section{“Quem Pode me Ajudar"? A Superação do Sofrimento}

Sete crianças apontaram as pessoas a quem elas recorrem para buscar ajuda quando estão em uma situação que não sabem como resolver. Yacón: Eu só tenho meu diário, mas esse eu não posso falar, né? (...) Deus! (...) Meu pai? (...) Sei lá! O psicólogo? (...) O juiz? 
(...) Só! Cacau: Vizinha. Esmeralda: Eu conto para a minha mãe, para a minha vó... Mirtilo: Com a minha avó. (...) Minha mãe. Calunga apontou o pai: (...) minha mãe falou: "vocês querem ficar com quem, comigo ou com seu pai”? Eu falei que "com meu pai”! Para Ônix, a mãe é a figura que representa segurança para ele: Ela [mãe] sempre cuidou de mim... No entender de Ágata, o pai é uma pessoa com a qual não pode contar: Porque assim, eu acho que nunca tive vontade de ver ele, nunca! Assim, cheguei uma hora a parar e pensar nele, nunca tive nenhum sentimento assim.... (...) Normal, como se eu não tivesse assim um pai.... Todavia, Ágata expressou poder contar com a mãe: Aí minha mãe sempre ia conversar comigo, falar que eu não podia ver ele porque o juiz não deixava. Mirtilo apontou a avó materna: (...) Minha vó vai pegá a minha guarda. (...) Porque eu pedi pra ela. Porque deu vontade de morar com ela. Jasmim não indicou ninguém, nem mesmo os irmãos: Prefiro não conversar não [com os irmãos], assim como Berilo: (...) eu sei que eu tô muito sozinho, triste às vezes eu fico. (...) Ah! Eu não me lembro direito, a minha irmã não... não conversava muito comigo, porque ela gostava mais de brincar ou ficava no computador.

Neste núcleo, as crianças demonstraram reconhecer que não conseguem interferir no conflito de modo a solucioná-lo pois identificam depender de um adulto que as apoiem em sua fragilidade e vulnerabilidade, as protejam e lhes dê segurança, no desenvolvimento de sua autonomia (Cashmore, 2011; Minuchin, 1990; Minuchin et al., 2009; Santa Rosa et al., 2013). As características individuais de cada criança permitem que ela se mobilize (Amato, 2014) na busca de alguém para atendê-la e diminuir o seu sofrimento, especialmente quando a dinâmica interparental envolve conflito. Portanto, entende-se que as crianças que não apontaram o apoio de alguém para acolhê-las, Jasmim e Berilo, pode ser indicativo de estarem sem o apoio emocional de que necessitam. Assim, importa investigar outros aspectos que podem fazer parte da dinâmica da criança, como rendimento escolar, saúde física, que pode 
estar debilitada, bem como a expressão de comportamentos de risco, além de aspectos patológicos que podem envolver os pais (Nunes-Costa et al., 2009).

Yacón, ao indicar possibilidades para a obtenção de apoio, não expressa convicção. Isso pode significar que sua rede familiar e social esteja enfraquecida. Um dos motivos pode ser a ausência ou a perda de relacionamentos significativos, em especial, da família ampliada (Fuhrmann \& Zibbel, 2012), em consequência dos conflitos interparentais que perduram após a separação/divórcio. Se a criança não se sente apoiada, não se sente amada, sente-se como se não existisse, expressando, assim, sua fragilidade. Além disso, o fato de os pais estarem envolvidos em permanente conflito, torna a comunicação familiar empobrecida, afetando a qualidade da interação com os filhos, bem como o processo de desenvolvimento dela em relação à confiança e autonomia (Johnston et al., 2009; Portugal \& Alberto, 2014).

Neste núcleo, o desenho feito apenas com o lápis preto $n^{\circ}$ 2, apresentado por Cacau, traz sua preocupação (Anexo 14): Os dois brigando (os pais). (...) Tristes. (...) (sobre onde ele está) Em lugar nenhum! Cacau desenhou duas figuras humanas pequenas em relação à folha e parecem soltas no ar. A boca está representada por um traço indicando não haver fala e, os braços, embora abertos, não têm as mãos, indicando falta de conexão com o mundo externo. Os pés estão presentes indicando haver equilíbrio para manterem-se em pé. Nesse desenho, Cacau não está representado. Durante a entrevista, a criança informou que quando os pais brigam, evita assistir às cenas e dirige-se à casa da vizinha. O desenho da solução (Anexo 15), também feito em lápis preto $\mathrm{n}^{\circ}$ 2, Cacau expressa um apelo: Parar de brigar! Sobre a expressão das figuras no desenho, a criança descreve estarem: Felizes! Cacau consegue imaginar um final feliz com a interrupção da briga dos pais. Agora, também pequeno em relação à folha, ele se inclui, e todos estão sorrindo indicando felicidade. Contudo, as figuras não possuem mãos (tal como no primeiro desenho), nem pés, estando soltas no ar, sem 
contato com o chão. Observa-se a necessidade da busca pelo equilíbrio e do contato com o mundo externo (Puviani, 2011).

Verifica-se, portanto, que a criança, por estar desenvolvendo sua autonomia, recorre ao apoio de alguém para superar o seu sofrimento. Inicialmente, ela procura segurança no interior da díade parental, posteriormente, recorre a familiares significativos do sistema ampliado e, se não encontra destas duas maneiras, recorre a pessoas que a acolham. A verbalização e o desenho aqui apresentados mostram que as informações se complementam a respeito das percepções da criança em relação ao contexto familiar em que está inserida, tornando visíveis seus sentimentos (Andolfi, 2013; Puviani, 2011), no intuito de suplantar o sofrimento.

O presente núcleo apontou que a criança, a despeito do conflito que vivencia e revela durante a avaliação psicossocial quando está em disputa a sua guarda, consegue expressar a busca pela sua autonomia ao ser-lhe oferecido espaço de escuta. Apontou, ainda, que ela, apesar de depender dos pais ou de adultos responsáveis por ela, consegue distinguir suas necessidades dos sentimentos relacionados ao conflito interparental. Consegue apontar suas fragilidades e vulnerabilidades, bem como sua força com a busca pela diminuição de seu sofrimento quer seja no interior de sua família, quer na rede social (amigos e vizinhos), para obter a proteção e a segurança de que necessita. Revela, também, recorrer a profissionais da saúde e da Justiça, quando tem essa oportunidade, para o atendimento do seu bem-estar. Além desses apoios, Deus também é um indicativo de possibilidade de ajuda na superação de seu sofrimento emocional (Kiesling, 2011).

\section{Considerações Finais}

$\mathrm{Na}$ interação entre os sistemas familiares, que inclui pai, mãe e filhos, em processos de disputa de guarda, a Justiça, representada pela figura do juiz, pode, em certos casos, 
determinar que se realize uma avaliação psicossocial com o objetivo de atender ao princípio do melhor interesse da criança, conforme aponta a Convenção sobre os Direitos da Criança (UNICEF, 1990).

Nessa perspectiva, este artigo objetivou analisar como a criança expressa o seu sofrimento durante a avaliação psicossocial no contexto da Justiça em situação de conflito familiar, quando os pais, que estão separados/divorciados, disputam a sua guarda e a regulamentação de visita. Concluiu-se que a criança, ao ocupar o lugar de protagonista de sua própria história, é capaz de apontar os sentimentos que envolvem seu sofrimento, a origem e as soluções que vislumbra para superá-lo, quando seus pais se separam/divorciam e há conflito interparental.

Os resultados da pesquisa revelaram, também, que tristeza, solidão, agonia, angústia, saudade, amor e raiva são os sentimentos que as envolvem nesse momento de mudanças, gerados pela separação/divórcio parental e agravados pelo permanente conflito interparental. Apesar do contexto conflituoso, a criança consegue desenvolver sua autonomia, na busca do aumento de sua autoestima e confiança na dependência que tem de seus pais. Com isso, a criança consegue encontrar saídas que considera justas para o impasse que vivencia ao sentirse emocionalmente dividida e em busca de uma "verdade" a seu respeito que a acalme. Ela quer expressar o seu amor por seus pais e quer ter a garantia de que não será abandonada (Johnston et al., 2009; Minuchin, 1990; Minuchin et al., 2009; Sthal, 2011). Desse modo, para a criança, as possibilidades de superação estão no suporte dos adultos aos quais ela recorre para obter proteção e segurança, partindo de seus pais, passando por seus familiares, alcançando vizinhos e amigos, profissionais e até Deus. Portanto, a criança expressa sua capacidade em fazer elaborações mentais que possibilitem encontrar alternativas na superação de seu sofrimento, apesar de sentir-se responsável pelo conflito parental em razão da disputa de sua guarda que conduziu seus familiares à Justiça. Assim sendo, oferecer 
espaço para expressar-se no contexto judicial, contribui para que o juiz esteja mais próximo de suas reais necessidades, favorecendo acordos mais viáveis e efetivos (Santa Rosa et al., 2013). 


\title{
ARTIGO EMPÍRICO 2 DA PESQUISA
}

\section{Sobrevivência da criança aos conflitos familiares em disputas de guarda}

\author{
Marcia Regina Ribeiro dos Santos
}

Liana Fortunato Costa

\section{Resumo}

Este artigo, oriundo de uma pesquisa qualitativa, analisou as estratégias utilizadas pela criança ao enfrentar seu sofrimento durante litígio familiar e reveladas durante a avaliação psicossocial quando sua guarda está em disputa. Participaram 11 crianças com idades entre 8 e 11 anos. Como instrumentos, utilizou-se a entrevista semiestruturada e desenhos produzidos por elas. A análise das informações resultou em três núcleos de sentido: como a criança se sente em relação aos componentes da família, sua percepção sobre as relações familiares; como se sente em relação a ter que escolher entre pai ou mãe; e intervenções/ações/estratégias empreendidas por ela para sobreviver ao conflito parental/familiar. Os resultados revelaram que a criança usa estratégias para sobreviver, conjugadas entre suas elaborações psíquicas e as ações que consegue expressar no contexto familiar. A eficácia dependerá do seu sentimento em relação à proteção, acolhimento e respeito ao ter atendidas suas necessidades, ciente de sua dependência dos adultos em razão de sua vulnerabilidade. Assim, a criança busca fortalecer os vínculos de pessoas significativas para ela (irmãos e avós), além do pai e da mãe, que estão separados e em conflito, articulando a trajetória da família na Justiça, direcionando os profissionais que a avaliam e o juiz que sentencia para que estes atores respondam de acordo com sua realidade.

Palavras-chaves: Estratégias de enfrentamento, conflito familiar, disputa de guarda 


\title{
Child survival due to familial conflicts in custody disputes
}

\begin{abstract}
The current article results from a qualitative research and analyzes the strategies used by children to face their suffering during family lawsuit. These strategies are revealed during psychosocial evaluation, as the study dispute is still on. Eleven children between 8 and 11 years old participated in the experiment. Semi-structured interview and drawings made by the children were used as tools. The analysis of the gathered information led to three meaning units: how children feel about family members, their perception about familial relationships; how they feel about having to choose between the father or the mother; and interventions/actions/strategies undertaken by them to survive the parental/familial conflict. Results show that children use survival strategies achieved by their psychic elaborations and the actions they can express in the familial context. The strategies' efficiency will depend on their sense of protection, reception and on the respect for having their demands fulfilled when they are aware of their dependence on adults due to their biological vulnerability. Thus, children aim to strengthen the bonds with people who are important to them (brothers, sisters and grandparents), since the father and the mother are apart and in conflict, setting the future of the in court and influencing the professionals who evaluate the situation, and the judge who sentences claim to respond according to the parents' reality.
\end{abstract}

Keywords: Coping strategies, family conflict, custody dispute

\section{Supervivencia de los niños a los conflictos familiares en disputas de guarda}

\section{Resumen}

Este artículo, originario de una investigación cualitativa, analizó las estrategias usadas por niños al enfrentar su sufrimiento durante litigio familiar y revelado durante la evaluación psicosocial cuando su guarda está en disputa. Participaron 11 niños con edades entre 8 y 11 
años. Como instrumentos, se utilizó la entrevista semiestructurada y dibujos producidos por los niños. El análisis de las informaciones resultó en tres núcleos de sentido: cómo el niño se siente en relación a los componentes de la familia, su percepción sobre las relaciones familiares; cómo se siente en relación a tener que escoger entre padre o madre; e intervenciones/acciones/estrategias emprendidas por ellos para sobrevivir al conflicto parental/familiar. Los resultados revelaron que el niño usa estrategias para sobrevivir, conjugadas entre sus elaboraciones psíquicas y las acciones que consigue expresar en el contexto familiar. La eficacia dependerá de su sentimiento en relación a la protección, acogida y respeto al tener atendidas sus necesidades, conscientes de su dependencia de los adultos en razón de su vulnerabilidad biológica. De esta manera, el niño busca fortalecer los vínculos de personas significativas para él (hermanos y abuelos), además del padre y de la madre, que están separados y en conflicto, articulando la trayectoria de la familia en la justicia, direccionando los profesionales que lo evalúan y el juez que sentencia, para que estos actores respondan según su realidad.

Palabras clave: Estrategias de afrontamiento, los conflictos familiares, disputa por la custodia

A separação conjugal/divórcio é um evento estressante em razão das mudanças que acarreta para todos os membros da família (Raposo et al., 2011) e, quando envolve conflito parental, ocasiona prejuízos à saúde física e emocional dos filhos (Abela \& Walker, 2014; Nunes-Costa, Lamela \& Figueiredo, 2009; Owen \& Rhoades, 2012; Shelton \& Harold, 2007), sendo considerado mais destrutivo para as crianças do que o conflito conjugal, em razão de o foco negativo recair sobre elas (Kelly, 2012). Na família, cada componente utiliza recursos pessoais/esforços intrapsíquicos de modo diferenciado para superar as adversidades. Nesse sentido, Farinha e Afonso (2009) e Lisboa, et al. (2002) referenciam os estudos de Folkman e Lazarus (1980), ao tratarem das estratégias de enfrentamento ou coping que, conforme esses 
pesquisadores, envolvem a busca de alternativas para resolver, tolerar, reduzir ou minimizar os problemas, conjugando-se esforços entre as ações e o psiquismo / a pessoa e o ambiente. As crianças que recebem atenção e carinho acolhedor da mãe e firmeza na imposição das regras mostram-se propensas a desenvolver estratégias mais eficazes de enfrentamento (Vélez, Wolchik, Tein, \& Sandler, 2011).

Do ponto de vista do sistema familiar, a criança demonstra competência ao expressar alternativas que vislumbra a superação das dificuldades que vivencia na família (Andolfi, 2013) ao revelar suas preocupações em contexto de avaliação de disputa de guarda. Uma das possibilidades utilizadas pela criança refere-se ao fortalecimento da fratria, por intensificação do suporte emocional, que pode ser visto como uma estratégia de enfrentamento do conflito familiar na ocorrência de separação/divórcio de seus pais. Entretanto, dependendo da intensidade do conflito entre os pais e da lealdade existente, a relação entre os irmãos pode se apresentar de modo tenso, indicando ser este, possivelmente, o tipo de interação que havia antes da separação/divórcio dos pais. Além disso, a atenção e cuidados diferenciados entre pais e filhos, bem como tratamento preferencial entre irmãos, acrescidos pelo rompimento na relação parental, também podem promover rivalidades e/ou ciúmes pós-separação (Shumaker, Miller, \& Ortiz, 2011).

Assim, este artigo analisou as estratégias utilizadas pela criança no enfrentamento do seu sofrimento a respeito do litígio familiar reveladas durante a avaliação psicossocial nos processos em que há disputa de sua guarda.

\section{Método}

A presente investigação pautou-se na pesquisa qualitativa que utiliza a interpretação como fundamento (Bauer, Gaskell, \& Allum, 2010; Flick, 2009). Sem perder de vista as interações familiares, a pesquisa aqui relatada privilegiou a entrevista apenas com a criança. 
Assim, a análise parte do olhar que a criança traz do contexto familiar, observado no momento da avaliação psicossocial durante a tramitação do processo de disputa de sua guarda e regulamentação de visita na Justiça. As informações foram obtidas no decorrer da realização do estudo psicossocial, de onde emergiu o tema estudado, seguido da análise e interpretação do significado dessas informações, produzindo-se novos conhecimentos (Creswell 2010; Flick 2009).

\section{Contexto}

A pesquisa ocorreu no Tribunal de Justiça do Distrito Federal e dos Territórios (TJDFT), que contempla a Secretaria Psicossocial Judiciária (SEPSI), subdividida em duas Subsecretarias, sendo que uma delas é responsável pelo Serviço de Assessoramento às Varas Cíveis e de Família (SERAF). Esse serviço atende famílias oriundas de varas de família, encaminhadas pelo juiz, e é composto por assistentes sociais e psicólogos. As informações para a pesquisa foram colhidas durante o processo habitual de avaliação psicossocial que incluiu o acolhimento individual da criança em disputa.

\section{Participantes}

O principal indicativo para a seleção dos casos para a pesquisa foi o fato de a dinâmica familiar evidenciar intenso conflito, crônico ou não, principalmente, entre o par parental (Johnston, Roseby, \& Kuehnle, 2009). Os participantes da pesquisa foram 11 crianças pertencentes a nove famílias, com idades que variaram entre 8 e 11 anos. Para melhor entendimento, as informações relativas à qualificação das crianças estão descritas na tabela 1 , a seguir. 
Tabela 1

Informações das Crianças Participantes da Pesquisa e da Ação Judicial por Família

\begin{tabular}{|c|c|c|c|c|c|c|c|c|}
\hline \multirow[b]{2}{*}{$\begin{array}{l}\text { Famí- } \\
\text { lia }\end{array}$} & \multicolumn{4}{|c|}{ Informações sobre as crianças } & \multicolumn{4}{|c|}{ Ação judicial } \\
\hline & Nome & $\begin{array}{l}\text { Idade/ } \\
\text { sexo }\end{array}$ & $\begin{array}{l}\text { Ano } \\
\text { esco- } \\
\text { lar }\end{array}$ & $\begin{array}{l}\text { Reside } \\
\text { com }\end{array}$ & Tipo & $\begin{array}{l}\text { Movida } \\
\text { por }\end{array}$ & Contra & Motivo \\
\hline F1 & Jaspe & $\begin{array}{l}11 / \\
M\end{array}$ & $6^{\circ}$ & $\begin{array}{l}\text { Pai e } \\
\text { Irmã (13 } \\
\text { anos) }\end{array}$ & RDUE & Pai & Mãe & $\begin{array}{l}\text { Violência } \\
\text { interparental, } \\
\text { uso abusivo de }\end{array}$ \\
\hline & Ônix & $\begin{array}{l}8 / \\
M\end{array}$ & $3^{\circ}$ & $\begin{array}{l}\text { Mãe e } \\
\text { irmã (4 } \\
\text { anos) }\end{array}$ & & & & $\begin{array}{l}\text { álcool e } \\
\text { negligência dos } \\
\text { filhos. }\end{array}$ \\
\hline F2 & Jasmim & $\begin{array}{l}9 / \\
\mathrm{F}\end{array}$ & $3^{\circ}$ & $\begin{array}{l}\text { Mãe e } \\
\text { irmão } \\
\text { (13 } \\
\text { anos) }\end{array}$ & GR & Mãe & Pai & $\begin{array}{l}\text { Mãe suspeita de } \\
\text { abuso sexual da } \\
\text { filha na casa } \\
\text { paterna por } \\
\text { enteados. }\end{array}$ \\
\hline $\mathbf{F 3}$ & Ágata & $\begin{array}{l}10 / \\
\mathrm{F}\end{array}$ & $5^{\circ}$ & $\begin{array}{l}\text { Mãe e } \\
\text { avós } \\
\text { mater- } \\
\text { nos }\end{array}$ & RV & $\begin{array}{l}\text { Avós } \\
\text { paternos }\end{array}$ & Mãe & $\begin{array}{l}\text { Visitas do pai à } \\
\text { filha suspensas } \\
\text { judicialmente } \\
\text { por abuso } \\
\text { sexual } \\
\text { comprovado. }\end{array}$ \\
\hline F4 & Mirtilo & $\begin{array}{l}9 / \\
M\end{array}$ & $3^{\circ}$ & $\begin{array}{l}\text { Mãe, } \\
\text { compa- } \\
\text { nheiro e } \\
\text { um } \\
\text { irmão } \\
\text { unilate- } \\
\text { ral (6 } \\
\text { anos) }\end{array}$ & $\mathrm{AG}$ & $\begin{array}{l}\text { Avós } \\
\text { maternos } \\
\text { mãe e pai }\end{array}$ & Não há & $\begin{array}{l}\text { Benefícios em } \\
\text { plano de saúde } \\
\text { e bolsa de } \\
\text { estudos para } \\
\text { língua } \\
\text { estrangeira. }\end{array}$ \\
\hline F5 & Berilo & $\begin{array}{l}8 / \\
M\end{array}$ & $2^{o}$ & $\begin{array}{l}\text { Mãe e } \\
\text { irmã (14 } \\
\text { anos) }\end{array}$ & RV & $\begin{array}{l}\text { Avó } \\
\text { paterna }\end{array}$ & Mãe & $\begin{array}{l}\text { Pai falecido } \\
\text { após a } \\
\text { separação } \\
\text { conflituosa. }\end{array}$ \\
\hline F6 & Yacón & $\begin{array}{l}9 / \\
M\end{array}$ & $4^{\circ}$ & $\begin{array}{l}\text { Pai e } \\
\text { compa- } \\
\text { nheira }\end{array}$ & RV & Pai & Mãe & $\begin{array}{l}\text { Acusação de } \\
\text { maus tratos } \\
\text { físicos e } \\
\text { psicológicos } \\
\text { durante as } \\
\text { visitas na casa } \\
\text { materna. }\end{array}$ \\
\hline F7 & $\begin{array}{l}\text { Esme- } \\
\text { ralda }\end{array}$ & $\begin{array}{l}10 / \\
\mathrm{F}\end{array}$ & $5^{\circ}$ & $\begin{array}{l}\text { Mãe, } \\
\text { avó e tio } \\
\text { mater- } \\
\text { nos }\end{array}$ & RV & Mãe & Pai & $\begin{array}{l}\text { Pedido de } \\
\text { suspensão das } \\
\text { visitas por } \\
\text { acusação de }\end{array}$ \\
\hline
\end{tabular}




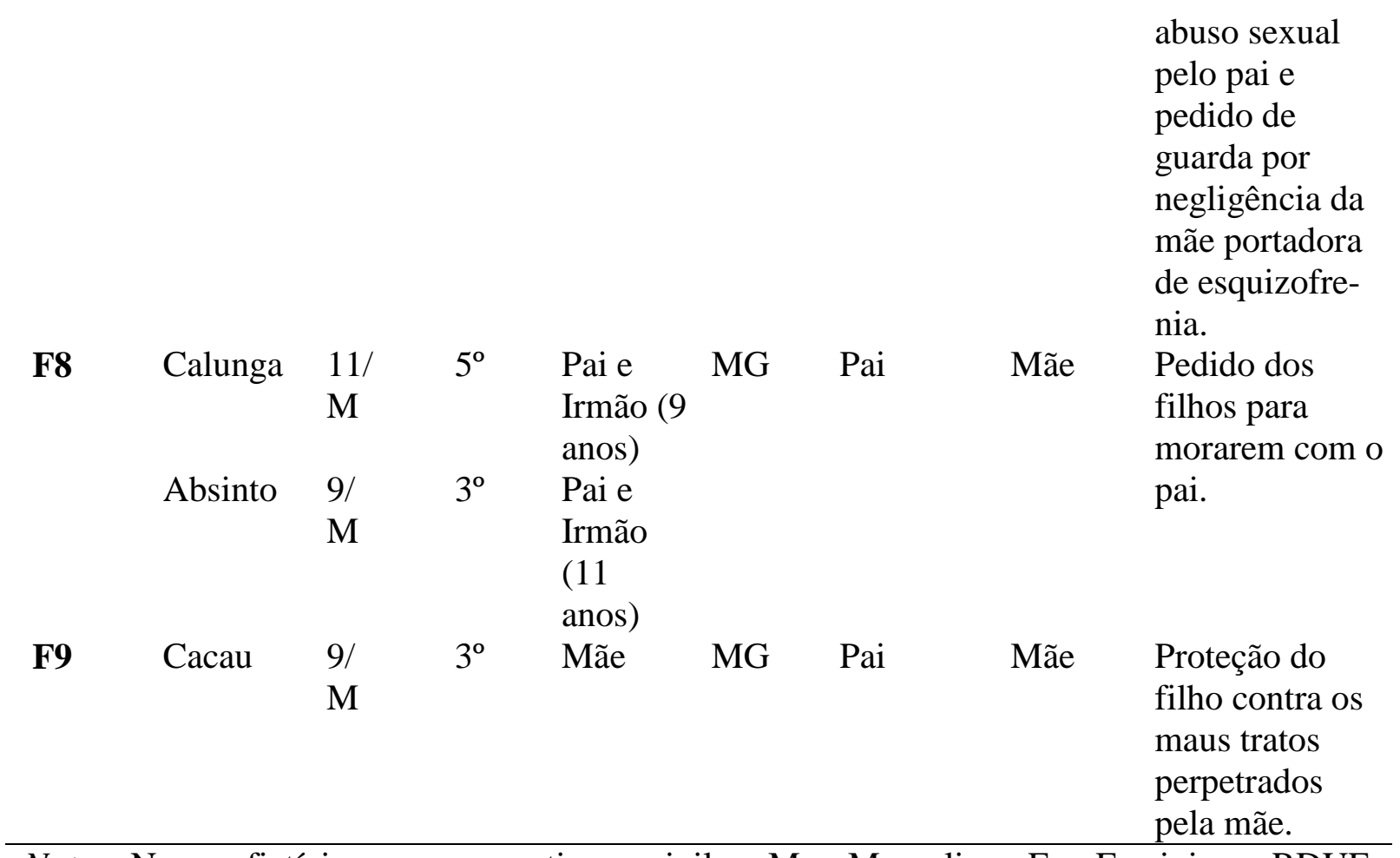

Nota: Nome fictício para garantir o sigilo. $\mathrm{M}=$ Masculino $\mathrm{F}=$ Feminino; RDUE= Reconhecimento e Dissolução de União Estável; GR= Guarda e Responsabilidade; $A G=$ Acordo de Guarda; RV= Regulamentação de Visita; MG= Modificação de Guarda.

\section{Instrumentos}

Os instrumentos utilizados foram os processos judiciais, as pastas onde são registradas as informações das famílias e os pareceres técnicos efetuados pelos profissionais responsáveis pela avaliação. Para obter essas informações com a criança, utilizou-se um roteiro, previamente elaborado, que serviu para guiar a entrevista. Esse roteiro englobou os seguintes aspectos com ênfase na percepção da criança: o motivo de estar na Justiça, as histórias contadas concernentes às suas percepções e vivências no contexto familiar, e as concepções sobre o seu sofrimento. O outro instrumento utilizado para obter informações sobre as expressões da criança foi o desenho conforme propõe Puviani (2011). Desse modo, mediante solicitação de uma das pesquisadoras que conduziu a entrevista individual, a criança poderia representar suas vivências referentes ao conflito familiar ensejado pela ação judicial. Assim, pediu-se que, em uma folha em branco, ela desenhasse as suas preocupações e, posteriormente, fizesse outro desenho, representando as soluções em relação às preocupações 
apontadas. A execução do desenho, tanto em relação às preocupações quanto às soluções, poderia requerer, por parte da criança, mais de uma folha de papel em branco. Além disso, na consigna para a confecção do desenho, sugeriu-se que fosse feito de duas maneiras. Uma delas seria representar as imagens que lhe viessem à mente e, a outra, que se inspirasse nos elementos que compõem a natureza, a partir dos reinos mineral, vegetal e animal. Isso poderia ampliar suas ideias, permitindo a livre expressão de sua criatividade. O desenho torna visível o mundo interno que está obscuro, relacionando-o com o exterior na comunicação de emoções. Desse modo, o desenho é visto como autorrevelação, integrando o verbal e o não verbal (Puviani, 2011).

\section{Procedimentos}

As salas onde as entrevistas foram realizadas estavam equipadas com material lúdico (jogos e brinquedos), folhas de papel em branco, lápis preto $\mathrm{n}^{\circ} 2$ e coloridos, giz de cera, além de material de apoio (cadeiras e mesa) com as medidas apropriadas para a criança. A obtenção das informações para a pesquisa ocorreu durante os meses de novembro e dezembro de 2013. O registro das referidas informações foi efetuado por meio da leitura de cada processo. Cada atendimento realizado pelos profissionais nas variações dos subsistemas familiares durou em média uma hora e meia, incluindo visitas às escolas e às residências, quando o caso requeria. As entrevistas com cada criança ocorreram no decorrer da avaliação efetuada pelos profissionais e tiveram a duração aproximada de 40 minutos, as quais foram gravadas em áudio e posteriormente transcritas. O conteúdo foi analisado na modalidade temática apontada por Minayo (2014) em que se obteve núcleos de sentido, aos quais foram atribuídos significados denominados de subnúcleos. 


\section{Cuidados éticos}

Para a realização da pesquisa, o projeto foi submetido ao Comitê de Ética em Pesquisa conforme resolução do CFP 016/2000 em que a aprovação incluiu o termo de compromisso pelo responsável do Tribunal de Justiça e os Termos de Consentimento Livre e Esclarecido (TCLE) para o responsável da(s) criança(s) e o Termo de Assentimento na forma oral para que a criança pudesse participar livremente da pesquisa.

\section{Resultados e Discussão}

As informações coletadas em relação à expressão da criança que envolveram observações de como a criança se apresenta, o que verbaliza, o que sente a respeito de sua história vivida no âmbito familiar, e quais estratégias ela consegue empreender a fim de reduzir seu sofrimento quando os pais se separam ou estão separados/divorciados e disputam a sua guarda, permitiram desenvolver três núcleos de sentido concernentes às estratégias de enfrentamento: 1. Como a criança se sente em relação aos componentes da família; 2. Como se sente em relação a ter que escolher entre pai ou mãe; 3. Intervenções/ações/estratégias empreendidas por ela para sobreviver ao conflito parental/familiar.

\section{Como a Criança se Sente em Relação aos Componentes da Família}

Neste núcleo, observou-se que as respostas das crianças foram diferentes em razão do enfoque dado por elas, considerando sua história e o momento que viviam. Ademais, todos os participantes verbalizaram suas percepções/seus sentimentos. Duas crianças, Yacón e Esmeralda, destacaram o modo punitivo de receber a educação de seus pais. Yacón observa haver semelhanças entre seus pais: (...) o meu pai parou de me bater, a minha mãe também. Esmeralda percebe diferenças: (...) o meu pai tinha que me bater para eu... (...) respeitar minha mãe... (...) da última vez que ele me deixou de castigo, minha mãe falou assim: não, não deixa ela de castigo não! Tanto Yacón quanto Esmeralda percebem ser a ligação entre os 
pais e observam como devem se comportar para receberem o amor deles. Johnston et al. (2009) apontam em suas pesquisas que, em crianças na faixa etária de Yacón e Esmeralda, o bom comportamento para terem a garantia do amor dos pais é um aspecto considerado importante. Nessa perspectiva, essas duas crianças mostram-se atentas às diferenças e semelhanças na educação que recebem do pai e da mãe, gerando tensão no relacionamento entre os pais e a criança.

Outro participante, Berilo, percebe que na relação entre sua mãe e sua avó paterna há desconsideração por parte de sua mãe nas solicitações da avó: (...) minha vó às vezes fala com a minha mãe, a minha mãe não fica nem aí! Berilo percebe haver distanciamento afetivo entre a mãe e a avó, o que dificulta a possibilidade de acesso ao apoio da avó. Shelton e Harold (2007) destacam que, dependendo do nível de conflito percebido pela criança nas interações familiares, ela não consegue obter o apoio de pessoas significativas que poderiam assegurar sua proteção. Assim, entende-se que Berilo não se sente encorajado a expor suas ideias, seus pensamentos para a mãe sobre o seu desejo de estar com a avó, nem em dizer para ela dar a atenção requerida pela avó. Mayall (2010) aponta que a criança se adapta às regras impostas pela mãe e depende dela para manter contato com sua rede expandida de familiares. Assim, Berilo indica estar contido pelas circunstâncias familiares, mas pode explicitar como se sente em relação aos componentes da família durante a avaliação, pois sente-se acolhido e em espaço de confiança para se expor.

O desenho foi utilizado como recurso complementar à entrevista para que a expressão dos sentimentos se tornasse visível, oportunizando a transformação de sua história e possibilitando a criação de novos contextos interacionais (Puviani, 2011). Desse modo, a preocupação exposta por Berilo no desenho (Anexo 29) referiu-se a um fato ocorrido momentos antes da avaliação psicossocial: (...) porque a minha mãe ficou brigando comigo... eu fico triste! Berilo desenha seu autorretrato com a expressão de aborrecimento em relação à 
repreensão recebida da mãe, que não aparece no desenho. Embora Berilo não descreva ter sofrido punição física, como apontado por Yacón e Esmeralda, ele destaca o sentimento de tristeza que a censura de sua mãe lhe causou. Nesse aspecto, sua expressão se assemelha ao dos outros dois participantes. Contudo, não se pode afirmar que a sua reação esteja relacionada ao conflito familiar, haja vista que a situação apresentada referia-se a um momento específico. Sobre o desenho relacionado à solução do que o preocupava(Anexo 30), Berilo fez um risco vertical, com lápis preto $\mathrm{n}^{\mathrm{o}} 2$, dividindo a folha em branco, e no sentindo horizontal, desenhou, na margem inferior, um traçado representando o chão na cor verde. Berilo disse: Ah, às vezes eu... teve um dia que passou pela minha cabeça que eu queria ficar uma semana lá... (na casa da avó) e uma semana na casa da minha mãe. Na solução, a criança representou como pode interagir com a mãe e a avó paterna: dividindo o seu tempo com cada uma. Berilo quer estar com a avó e quer conviver com essa senhora para receber o seu apoio emocional e sentir-se afetivamente fortalecido. Ele teme desagradar sua mãe e, ao reconhecer que há desentendimentos entre mãe e avó, apresenta uma solução estratégica que o proteja e diminua a tensão existente. Lisboa et al. (2002) apontam ser essa uma das razões de a criança apresentar alternativas de solução, pois revela a necessidade de reduzir o estresse que sente no contexto relacional familiar.

Este núcleo dos resultados apontou que a criança se reconhece dependente de seus responsáveis, embora se perceba como participante ativa no processo judicial, mostra-se expectadora das ações de seus familiares e aguarda ser protegida no atendimento de suas necessidades. Nesse contexto, ela também busca alternativas para reduzir seu sofrimento, sendo que suas ações e reações dependem de suas características individuais e do ambiente familiar no qual se insere (Farinha \& Afonso, 2009; Lisboa et al., 2002). Berilo, Yacón e Esmeralda reagem de modo a atender as expectativas de seus pais, seguindo as regras impostas por eles. Assim, essas crianças demonstram suas estratégias para terem a garantia do 
amor de seus pais (Johnston et al., 2009) e a redução do estresse que sentem pelo contexto beligerante. Elas, ao perceberem que estão no foco da disputa, ocupam a posição de mediadores para gerar equilíbrio entre pai e mãe e familiares significativos, e indicam como estratégia, a divisão do seu tempo na convivência com a família, em momentos diferenciados, para garantir a harmonia familiar e para manter o distanciamento entre os membros.

\section{Como a Criança se Sente em Relação a Ter que Escolher: Pai ou Mãe}

Neste segundo núcleo dos resultados, apesar de somente duas crianças participantes da pesquisa terem apresentado sentimentos ambivalentes no total de 11, optou-se por discutir este aspecto em razão de se considerar importante avaliar a dicotomia vivida pela criança, ao revelar dois sentimentos opostos com que está aprendendo a lidar. Destaca-se a fala de uma das crianças quando fez os desenhos. No primeiro desenho, referente ao problema, Absinto esclarece: Um coração. O amarelo é da alegria e o lado vermelho é da tristeza. (...) porque o lado vermelho é a tristeza, a tristeza dá lágrimas... de estar perto do meu pai... não, a alegria... é porque eu estou perto do meu pai. E eu queria misturar os dois (...) porque (...) estou longe da minha mãe... Cada cor é como se fosse uma parte, como se fosse aqui meu pai e aqui minha mãe, separados, e se juntasse ia dar uma briga. Absinto define o significado das cores e o traduz em relação aos sentimentos ambivalentes - alegria e tristeza - no convívio com o pai e com a mãe. Ele denuncia a interação conflituosa e, embora tenha o desejo de voltar a uni-los reconhece que ambos devem se manter separados ao perceber sobre a inconveniência de misturar as cores. A literatura que trata do conflito parental e disputa de guarda demonstra que há momentos em que a criança entende ser melhor que os pais permaneçam separados. Essa é uma maneira, encontrada pela criança, de sobrevivência ao contexto familiar beligerante. Essa estratégia possibilita que a criança se mantenha emocionalmente saudável, adapte-se ao ambiente e conserve-se protegida. Considerações 
sobre esses aspectos foram tecidas por Farinha e Afonso (2009), Pereira e Matos (2008), Shienvold (2011). Com isso, entende-se que a criança desiste de escolher entre pai e mãe/avó paterna, preferindo equilibrar-se entre as duas possibilidades. O desenho, tal como descrito por Andolfi (2013) e Puviani (2011), é um dos canais de expressão da criança que faz emergir sentimentos que se tornam visíveis diante de si mesma e revelam conteúdos que mostram sua sabedoria e competência. A criança revela estar em busca de ambiente familiar harmônico e cumpre o seu papel para a manutenção dessa organização, entendendo-se que suas estratégias objetivam atender suas expectativas em ter a garantia do amor do pai e da mãe.

A criança, ao desenhar o problema (Anexo 6), também aponta a solução (Anexo 7). Assim, Absinto, na sequência dos seus pensamentos, conclui: Já que os dois (pai e mãe) não podem se juntar vai ser uma coisa melhor: (...) que minha mãe fique comigo nos anos pares $e$ meu pai comigo nos anos ímpares! Absinto desenha duas figuras humanas de braços abertos como a buscarem um abraço. Representou o sol como a energizar e a trazer vida ao cenário. A estratégia de solução que apresenta garante a segurança de que necessita no atendimento de dois aspectos: um deles é o fato de a mãe e o pai não brigarem, reconhecendo não ser possível mantê-los juntos. O outro, é o vislumbre da possibilidade de ele conviver com ambos, que acredita estarem "de braços abertos" para recebê-lo em momentos distintos e únicos para ele. Esse desenho denuncia o desejo de Absinto em receber o amor de seus pais independente do conflito que há entre eles. Esse é o seu pedido. Após as reflexões feitas pela criança, observase que consegue encontrar uma alternativa que lhe parece eficaz pois garante que receberá o amor de ambos, (Johnston et al., 2009) e está em consonância com a organização familiar. Absinto sente-se seguro em desistir de escolher entre pai e mãe. Essa estratégia gera nele motivação e entusiasmo, ao mesmo tempo em que o tranquiliza e o conforta, pois acredita estar em consonância com as expectativas de ambos. Nesse desenho, Absinto completa seu raciocínio e mostra que ele será atendido em seus anseios se tiver parte do seu tempo com a 
mãe e outra parte com o pai, ensinando que as desavenças não devem afetar as relações entre eles e o filho.

\section{Estratégias Empreendidas pela Criança para Sobreviver ao Conflito Familiar}

Neste núcleo, o destaque será dado à interação do subsistema fraternal para retratar as diferenças e as (im)possibilidades de obtenção de apoio (Shelton \& Harold, 2007; Shumaker et al, 2011). Dos 11 participantes, as duas duplas de irmãos, Calunga e Absinto, Jaspe e Ônix, apresentam as características que se pretende destacar.

Calunga e Absinto demonstraram fortalecerem-se emocionalmente no enfrentamento que os envolve no contexto conflituoso de seus pais na disputa de guarda. Calunga esclarece: (...) meu pai não deixou a gente ser separado (ele e o irmão). A criança reflete o modo como compreendeu e aceitou o ordenamento do pai, acolhendo e adaptando-se à orientação recebida: Eu ajudo mais o meu irmão. Calunga ocupa um lugar de poder junto ao pai e garante a continuidade da família por meio do fortalecimento da relação fraternal. Mayall (2010), em seus estudos, verificou que a criança, quando mais velha, tem papel de destaque nessa posição. Assim, a criança, ao favorecer a manutenção da união, atende as expectativas paternas, uma das características de sua faixa etária (Johnston et al., 2009), demonstra companheirismo e camaradagem, acolhendo e apoiando o irmão na superação das dificuldades e, também, usufrui do sentimento de importância na assunção do papel de protetor e responsável pelo irmão mais novo. Sobre essa interação da fratria, Punch (2010) também destaca haver, para o irmão mais velho, o significado de proteção e responsabilidade com os mais novos. Em resposta, Absinto diz: Eu nem sabia o que era raiz quadrada! E ele (Calunga) tá me ensinando... Ele aceita o apoio do irmão, garantindo a união entre eles, apesar de os pais estarem separados e em conflito. Nessa perspectiva, a separação parental proporciona o fortalecimento do vínculo fraterno no apoio diário, tornando a interação imune 
à interrupção (Mayall, 2010), diferenciando-a da relação mãe-filhos que ficou obstruída com a referida separação e a dinâmica parental conflituosa (Shumaker et al., 2011).

Em uma outra dupla de irmãos, Jaspe e Ônix, a interação revela-se hostil. Ônix explica, em relação à dinâmica interparental: Eles discutiam. (...) Ele (pai) batia também... na minha mãe sim. (...) Ela nunca bateu. (...) Ela sempre queria, assim, sair, sair. (...) Ela batia também para sair... A criança denuncia apreender um modelo parental conflituoso, além de acreditar ser esse o tipo de relacionamento entre homem e mulher. Na visão de seu irmão Jaspe, os pais: (...) eles ficavam discutindo muito. Aí quando a minha mãe ficava bêbada meu pai ficava com raiva. Aí eles discutiam e de vez em quando um ia para cima do outro. A criança identifica o modelo parental como conflituoso e reconhece a relação homem e mulher como violenta. Essa organização permite que ela se alie ao pai e distancie-se da mãe. Essa organização também foi notada por Shumaker et al. (2011) em suas pesquisas.

Os irmãos, ao perceberem a interação parental, unem-se na mesma preocupação quanto aos possíveis resultados deste modo de relacionamento e decidem intervir durante as brigas. Assim, a reação descrita por Jaspe: Eu fico triste e tento separar. Tento parar... de fazer eles brigarem. Essa é a mesma atitude verbalizada por Ônix: É... a gente fica falando: "para, pai, para, mãe, para, para”! Os irmãos se unem pelo sofrimento, durante o conflito dos pais, que têm dificuldade na resolução de seus impasses. Jaspe e Ônix experimentam sentimentos semelhantes, o que os aproxima emocionalmente. As crianças, ao descreverem sua história, expressam com intensidade o significado de suas ligações afetivas e relacionais no sistema familiar (Andolfi, 2013). Assim, ao verem seus pais brigando, elas intervêm, utilizando sua voz e seu próprio corpo. Nesse momento, observa-se haver o fortalecimento da interação entre os irmãos para atingirem o mesmo objetivo: interromper o conflito parental na busca de apoio e proteção (Santos, 2014). 
Embora haja pontos de vista semelhantes quando há conflito parental, observa-se divergência em relação a outros aspectos da interação familiar, afetando a harmonia da fratria. Para Ônix: E não adianta eu falar nada não, se eu falar... o que eu falar... é mentira disso, é mentira daquilo, por causa que eu sempre falo e ele (Jaspe) fala que é mentira! (...) Eu tenho é raiva dele! A raiva que Ônix expressa provém da dinâmica relacional adotada por seus pais, mas ele atenua e desvia o foco do conflito parental e o direciona para o irmão mais velho. Essa interação também foi observada por Shelton e Harold (2007) quando realizaram pesquisas com a fratria. Jaspe responde para o irmão: Mentiroso! Porque quando a minha mãe brigava comigo... por causa que ela me expulsava de lá... Jaspe sente-se incompreendido pelo irmão mais novo e revela não se sentir acolhido pela mãe. Ônix retruca: É porque... Ele sempre me bate! (...) Aí a minha mãe não gostava disso. Qual mãe que gosta? (...) Aí a minha mãe mandava ele embora e saía de lá. Ônix mostra-se aliado à mãe e distanciado do irmão, de quem gostaria de obter apoio. À semelhança do rompimento parental que se sustenta pelo conflito, repete-se essa dinâmica na fratria, mantendo a rivalidade entre os irmãos, tal como observado nas pesquisas de Shumaker et al. (2011).

$\mathrm{Na}$ interação revelada por essas crianças, identifica-se haver conflito em três subsistemas: parental, fraternal e materno-filial (Minuchin, 1990; Minuchin, Nichols, \& Lee, 2009). A repetição dos comportamentos observados na interação parental é a maneira como Jaspe e Ônix enfrentam as adversidades em sua família, incluindo agressão física. Tendo em vista que os pais são modelos para os filhos, a repetição de comportamentos se insere nesse contexto, tal como notado por Shielvold (2011) em seus estudos. Assim, nas desavenças, as crianças se mantêm unidas e conservam a família unida, com ênfase na hostilidade e afeto intensos (Shumaker et al., 2011), reproduzindo e perpetuando o padrão relacional dos pais. Ônix sente-se protegido, cuidado e amado pela mãe e acredita que ela desaprova a atitude do irmão por amá-lo também. Contudo, não consegue convencê-lo disso e não compreende o 
sofrimento do irmão, não reconhecendo e nem legitimando os sentimentos expressos por Jaspe. Com isso, Ônix se fortalece na união com a mãe contra Jaspe, pois pela aliança estabelecida, o irmão ecoa a voz do pai, que por extensão, também estaria errado. Diante do seu pedido desesperado para ter o convívio do irmão, entendendo-se que o desespero é a força que o mobiliza, tenta fazê-lo mudar de ideia, porém não consegue. Os irmãos se dividem na busca de proteção, mantendo-se vinculados à mãe e ao pai, para se fortalecerem e sobreviverem perante a crise familiar que vivenciam. Esse padrão relacional também foi observado nas pesquisas de Shelton e Harold (2007) e Shumaker et al. (2011).

No desenho sobre o problema (Anexo 12), Jaspe atém-se ao comportamento da mãe, que desaprova, e entende ser a causa da discórdia neste subsistema: Aqui é a minha mãe bebendo... (...) [E] ela me expulsando! (...) [Aqui] Eu indo para casa... a minha. (...) Eu, meu pai e a minha irmã. No mesmo desenho, apresenta a solução, recorrendo ao pai, acreditando que estará protegido e terá com quem compartilhar suas crenças e visão de mundo. Os desenhos feitos pelas crianças representam suas vivências na família (Andolfi, 2013; Puviani, 2011). A dinâmica observada na interação entre Jaspe e a mãe, repete-se entre ele e Ônix. Isso mostra que Jaspe está propenso a repetir esse padrão de comportamento no meio social, expondo-se a contexto de violência, indicando reivindicar proteção, acolhimento e segurança. A repetição desse tipo de comportamento foi observada nas pesquisas de Shelton e Harold (2007) e de Shumaker et al. (2011).

Com relação ao problema apresentado por Ônix (Anexo 10), nota-se que sua preocupação está direcionada ao irmão: Eu tenho é raiva dele! Ele explica que o raio que desenhou sobre a cabeça do irmão é Para ele pegar fogo e morrer! (...) Tem uns trovões caindo! (...) As nuvens...(...) Tem os pingos... As suas imagens mentais são representadas pelas nuvens, de onde saem gotas, raios e trovões. O sofrimento de Ônix está significativamente representado por esses elementos que se repetem nas figuras desenhadas na 
parte inferior do papel. O questionamento feito por ele diante do pai que, na representação se mostra fisicamente mais forte do que ele, o apresenta como um adulto que tem uma força diferente da sua. Ônix expressa sua fragilidade por meio das lágrimas, requerendo ser acolhido e compreendido pelo pai. Constata sua impotência em modificar o quadro familiar sem compreender que o irmão experienciou vivências diferentes dele. Ônix não consegue ver que o irmão está em busca de apoio e proteção tanto quanto ele e que também espera receber o amor da mãe. A cena representada pelo desenho reafirma que o conflito entre os pais se repete na interação entre os irmãos, cuja relação parental lhes serve como modelo. Ambas as crianças recorrem, cada uma a seu modo, à segurança e ao acolhimento de cada um dos pais para a sua sobrevivência física e emocional, reproduzindo comportamentos observados por Shelton e Harold (2007) e Shumaker et al. (2011).

Como solução (Anexo 11), Ônix apresenta: Eu, minha mãe e a Cacá. Feliz! (...) É o coração! A criança desenha gotas, agora em formatos de coração, representando o amor que sente e busca na mãe. Inclui uma terceira figura humana, a irmã de quatro anos, com quem também reside. As gotas oriundas da água que caía das nuvens, no primeiro desenho, se transformaram em dois corações, demonstrando sua necessidade em receber o amor da mãe e em sentir-se protegido e acolhido. Lisboa et al. (2002) atesta em suas pesquisas que o sofrimento emocional se reduz quando a criança recorre a ações para superá-lo. Nesse sentido, pode-se entender que as estratégias de enfrentamento de Ônix estão relacionadas com a redução do seu sofrimento emocional. Com isso, Ônix sintoniza-se com as emoções da mãe, deixa transparecer que ambos estão fragilizados e expressa a necessidade de receberem ajuda. Para ele, a solução é unir-se à mãe na obtenção de apoio mútuo. Os pais mantêm-se nas mesmas posições de beligerância e não percebem as necessidades dos filhos. Ônix sente-se sozinho nessa empreitada visto que não consegue convencer o irmão de que também deveria estar com ele para ajudá-lo a enfrentar as dificuldades que vivencia. 
Este terceiro núcleo destacou a interação entre os irmãos tanto no concernente à obtenção de apoio quanto às diferenças existentes nesse subsistema (Shelton \& Harold, 2007; Shumaker et al., 2011). Mostrou haver tanto o fortalecimento quanto a rivalidade na fratria que é mantida após a separação parental conflituosa. No fortalecimento, as duas crianças sentem-se protegidas, acolhidas e seguras nessa interação. O sofrimento é elaborado, possibilitando a redução do estresse. Na rivalidade, os irmãos buscam proteção, dividindo-se ao recorrerem um ao apoio do pai, outro da mãe, sem conseguirem agir de modo a efetuarem a elaboração psíquica suficiente para a superação das dificuldades relacionais vividas (Catarino, 2013; Farinha \& Afonso, 2009; Lisboa et al., 2002). Com isso, os efeitos do estresse na família se acentuam, sendo que a divisão da fratria é a estratégia de sobrevivência utilizada na redução do sofrimento oriundo da interação parental conflituosa. O risco da manutenção desse padrão interacional entre os irmãos é a tendência à repetição do comportamento agressivo em outros contextos sociais (Shelton \& Harold, 2007; Shumaker, et al, 2011). Nesse caso, verifica-se que as crianças denunciam não terem suas necessidades de proteção e segurança atendidas, requerendo que, no decorrer da avaliação psicossocial, sejam tomadas providências para obtenção de apoio na rede de assistência social para retomada e fortalecimento de suas competências.

\section{Considerações Finais}

Este artigo analisou as estratégias utilizadas pela criança ao enfrentar seu sofrimento a respeito do litígio familiar, as quais foram reveladas durante a avaliação psicossocial nos processos em que há disputa de sua guarda. Os resultados mostraram que o conteúdo do discurso expresso pela criança revela-se como recursos de aprendizado, conhecimento e amadurecimento para abrandar seu sofrer, em razão das mudanças oriundas da separação/divórcio conjugal e do conflito parental/familiar existente. Verificou-se que as 
crianças participantes da pesquisa apresentaram diferentes estratégias de sobrevivência, pois suas elaborações psíquicas e suas ações no ambiente dependerão de suas características individuais e do contexto familiar no qual estão inseridas (Farinha \& Afonso, 2009; Lisboa et al., 2002). Os efeitos em relação às estratégias utilizadas para sua sobrevivência serão mais ou menos eficazes se a criança conseguir perceber-se ouvida e sentir-se protegida, acolhida e respeitada no atendimento de suas necessidades, pois se reconhece dependente dos adultos diante de sua vulnerabilidade biológica (Lisboa et al., 2002; Mayall, 2010). Desse modo, a criança pode posicionar-se como mediadora para equilibrar as relações familiares, garantir a harmonia do contexto e, também, desistir de escolher entre conviver com o pai ou a mãe para ter a garantia do amor dos dois.

Os resultados apontaram também que a criança recorre ao fortalecimento dos vínculos de pessoas significativas para ela (pai, mãe, irmãos, avós) em razão das mudanças advindas da separação parental, mantidas pelo conflito nas relações familiares (Shumaker et al., 2011). As fratrias estudadas apresentaram duas versões, as quais se coadunam com a literatura nesta área: o fortalecimento do vínculo como estratégia de apoio emocional e a repetição do modelo parental conflituoso que possivelmente teve origem antes da ocorrência da separação conjugal Shelton \& Harold, 2007; Shumaker et al., 2011). Na primeira situação, o fortalecimento do vínculo fraterno tem o apoio do pai que se mostrou importante na garantia da continuação da família de pais separados. O compartilhamento de cuidados em momentos diferentes parece atender, pelo menos em parte, às expectativas das crianças. Na segunda, os laços afetivos se apresentaram hostis, com afeto expresso de modo intenso. Essa estratégia protege o subsistema parental conflituoso, mantém os pais afastados e sobrecarrega emocionalmente as crianças envolvidas. Entende-se que essa organização é insuficiente para atender ao bem-estar das referidas crianças e necessita ser revista com o apoio da rede de assistência social na 
retomada da competência da família em razão da dinâmica apontada por elas que mostram estar em contexto desprotetivo.

Portanto, a criança atua como articuladora da família e movimenta a trajetória que guiará os atores do tribunal no atendimento dos seus interesses. Conhecer e compreender as estratégias utilizadas pela criança ao enfrentar seu sofrimento para sobreviver ao contexto de conflito parental e disputa de sua guarda permite à Justiça estar mais próxima da realidade dela na garantia de sua proteção e segurança, independente do arranjo da custódia a ser implementada. 


\section{ARTIGO EMPÍRICO 3 DA PESQUISA}

Da invisibilidade à participação: a expressão da criança em disputas de guarda De la invisibilidad a la participación: la expresión del niño en litigios por la custodia

From invisibility to participation: the child's expression in child custody disputes Expressão da criança em disputas de guarda ${ }^{3}$

Marcia Regina Ribeiro dos Santos

Pesquisa realizada no Tribunal de Justiça do Distrito Federal e dos Territórios

Doutoranda do Programa de Pós-Graduação em Psicologia Clínica e Cultura (PPGPsiCC) da Universidade de Brasília - UnB - Brasil

Liana Fortunato Costa

Doutora em Psicologia Clínica pela USP

Docente Permanente do Programa de Pós-Graduação em Psicologia Clínica e Cultura (PPGPsiCC) da Universidade de Brasília- UnB - Brasil

Autor correspondente

Marcia Regina Ribeiro dos Santos

SHIN QI 7 Conj. 7 Casa 5, Lago Norte, 71515-070, Brasília DF, (61) 8162-1374

marciarrsantos@gmail.com

\footnotetext{
${ }^{3}$ Este artigo foi submetido a um periódico científico e está apresentado no formato exigido pelas normas da revista.
} 


\section{Da invisibilidade à participação: a expressão da criança em disputas de guarda}

\section{Resumo}

Este artigo é parte de uma pesquisa qualitativa e visou analisar como a expressão da criança sobre seu sofrimento, durante o processo de disputa de guarda e regulamentação de visita, pode significar a possibilidade de a decisão judicial ser mais assertiva em relação ao que importa no atendimento aos seus interesses. Participaram 11 crianças entre 8 e 11 anos de idade, de nove famílias que estavam sob avaliação psicossocial por determinação do juiz. Os resultados revelaram que a criança tem clareza do significado de sua participação do contexto judicial, quer ser ouvida e ter sua opinião considerada e respeitada. Além disso, a criança reconhece ter autonomia para informar o seu ponto de vista e admite depender dos adultos nas tomadas de decisão no que considera ser melhor para ela.

Palavras-chave: Expressão da criança; contexto de disputa de guarda; decisão judicial

\section{De la invisibilidad a la participación: la expresión del niño en litigios por la custodia}

\section{Resumen}

Este artículo es parte de una investigación cualitativa cuyo objectivo fue analizar cómo la expresión del niño acerca de su sufrimiento durante el proceso de litigio por la custodia y regulación de las visitas puede significar la possibilidad de una sentencia positiva y dirigida a los intereses del niño. Los participantes del estudio fueron 11 niños de entre 8 y 9 años, de nueve familias bajo evaluación psicosocial por determinación del juez. Los resultados revelaron que el niño es consciente de la importancia de su participación en el proceso judicial, quiere ser escuchado y quiere que sus opiniones sean consideradas y respetadas. Además, el niño reconoce tener autonomía para informar su punto de vista y reconoce su dependencia de los adultos en la toma de decisiones en lo que se considera mejor para él.

Palabras clave: Expresión del niño; litigios por la custodia; decisión judicial 


\title{
From invisibility to participation: the child's expression in child custody disputes
}

\begin{abstract}
This article is part of a qualitative study and sought to analyze how the child's expression of his or her suffering, during child custody dispute processes and the establishment of visitation schedules, may result in court rulings being more assertive with regard to meeting the child's interests. Eleven children aged 8 and 9 from nine families under court-ordered psychosocial evaluation participated in the study. The results showed that the children were aware of the meaning of their participation in the judicial context, that they wanted to be heard, and wanted to have their opinions considered and respected. In addition, the children acknowledged that they were free to state their points of view and admitted to depending on adults in decisionmaking about what is best for them.
\end{abstract}

Keywords: Expression of the child; child custody; dispute context; court decision

Este artigo tem origem em uma pesquisa qualitativa mais ampla, realizada em contexto de Justiça e tem como objetivo conhecer o sofrimento da criança durante a realização da avaliação psicossocial, em casos de disputa de guarda e regulamentação de visita, que pode significar a possibilidade de a decisão judicial ser mais assertiva em relação ao que importa no atendimento aos seus interesses.

No Brasil, o princípio do melhor interesse da criança, estabelecido pela Convenção sobre os Direitos da Criança passou a ser constitucional e infraconstitucional (Constituição Federal de 1988, Art. 227, caput, e Estatuto da Criança e do Adolescente, arts. $4^{\circ}$, caput, e $5^{\circ}$ ), desde que a Assembleia Geral das Nações Unidas o aprovou em 20 de novembro de 1989, entrando em vigor em 2 de setembro de 1990. Sua inclusão objetivou nortear a ação das instituições públicas em atender aos direitos da criança dependente de adultos responsáveis para auxiliá-la a desenvolver-se. Além de ser aplicado pelo Estado, o referido princípio deve 
ser incorporado e cumprido pela família e também pela sociedade (Kreuz, 2012). Esse princípio é considerado meta-jurídico e necessita da contribuição de outras áreas da ciência, pois requer entendimentos de vários interessados envolvidos: a própria criança, seus pais, outros familiares, profissionais da psiquiatria, serviço social, psicologia, juízes, dentre outros como contribuição na obtenção de subsídios para a decisão (Monteiro, 2010). Entretanto, pela natureza das opiniões científicas, não há certezas absolutas, sendo necessário esclarecer quanto às inerentes limitações pela particularidade de cada família que recorre a esse contexto (Santa Rosa, Almeida, Corte-Real, 2014).

A tomada de decisão do juiz envolve o atendimento ao princípio do melhor interesse da criança o qual implica o direito de ela ser ouvida sobre todos os assuntos que lhe são referentes, conforme artigo 12 da Convenção sobre os Direitos da Criança (UNICEF, 1990) e, primordialmente, o reconhecimento de sua dignidade e autonomia (Monteiro, 2010). Desse modo, analisar como o sofrimento da criança, expresso na avaliação psicossocial de disputa de guarda e regulamentação de visita para subsidiar a decisão judicial, bem como enfatizar sua expressão nesse âmbito (Skjørten, 2013), significa buscar a preservação do seu bem-estar, observando-se a qualidade de sua interação com a família, respeitando-se suas necessidades individuais, que são específicas e únicas, a saúde mental e física de todos os envolvidos, e considerando-se sua idade e grau de maturidade (Fuhrmann \& Zibbel, 2012; Monteiro, 2010; UNICEF, 1990).

No contexto da Justiça, as decisões que envolvem criança estão entre as mais difíceis de serem tomadas (Ackerman, 2006; Fuhrmann \& Zibbell, 2012; Graham \& Fitzgerald, 2010; Grisso, 2003; Huss, 2009; Patel \& Choate, 2014; Santa Rosa, Corte-Real, \& Vieira, 2013; Santa Rosa et al., 2014). Assim, na Justiça de família, o melhor interesse da criança por ser um conceito amplo e deve ser analisado mediante cada caso. O juiz, ao decidir com base nesse critério, está imbuído de sua própria subjetividade (Huss, 2009; Skjørten, 2013), pois 
envolve a qualidade do afeto na interação dos pais com a criança, os desejos dela, e a competência parental na promoção do seu desenvolvimento (Agulhas \& Anciães, 2014; Santa Rosa et al., 2013; Stahl, 2011).

Entretanto, a implicação da criança nesse contexto significa um direito e não uma obrigação (Santa Rosa et al., 2013). Em processos de guarda e regulamentação de visita, algumas crianças nem sempre querem ser incluídas nas tomadas de decisão, outras estão ansiosas para oferecer suas contribuições em relação ao que lhes diz respeito. A criança reconhece haver diferença entre ter uma voz e ter que fazer uma escolha quando os adultos a interpelam (Birnbaum \& Saini, 2012; Cardoso \& Costa, 2014). Portanto, analisar a expressão da criança significa contemplar a autonomia de sua vontade, que engloba o desenvolvimento da capacidade crítica, concebendo-a como sujeito de direitos e que tem algo a dizer, considerando diferentes padrões relacionais de sua família e como suas preocupações podem estar afetadas pelo contexto em que está inserida (Cashmore \& Parkinson, 2007). Ao mesmo tempo, os pontos de vista e as perspectivas das crianças são, por vezes, ambíguos e nem sempre transmitem relatos facilmente discerníveis, ou contam histórias consistentes com o que os adultos querem ouvir, os quais nem sempre são claros sobre o objetivo da participação delas, confundindo-as entre permitir dizer o que pensam e terem de expressar a opinião sobre o que querem (Agulhas \& Anciães, 2014; Graham \& Fitzgerald, 2010; Santa Rosa et al., 2013; Santa Rosa, et al., 2014).

No âmbito nacional, a discussão relativa à participação da criança na Justiça, a partir de sua voz, em disputas de guarda e regulamentação de visita, apresenta-se de modo crítico, não há consenso e está em processo de construção. Verifica-se que o pano de fundo das discussões indica cuidado para não tornar a criança mero informante, evitando-se mantê-la na invisibilidade, e aceitando-a como sujeito de direitos, destacando sua indivisibilidade e integralidade, com apoio no princípio do melhor interesse dela, na valorização do seu 
protagonismo por meio de políticas públicas inclusivas e de qualidade (Arantes, 2009). Brito, Ayres e Amendola (2006) apontam que ouvir a criança é saber sua opinião sobre com quem deverá residir, como é a interação parental e como é tratada pelos pais. Ferreira (2008) questiona se o acatamento integral da vontade da criança é o caminho mais adequado no atendimento do seu melhor interesse, uma vez que tem sua voz permeada por motivações e efeitos da dialética familiar, em especial quando o profissional busca saber com quem ela quer morar. Ribeiro (2010) pontua não haver por parte dos pais que estão em intenso conflito na Justiça, priorização quanto às necessidades emocionais da criança, que estão focados em si próprios. A pesquisa de Cardoso e Costa (2014) discute a disputa de guarda envolvendo avós e netos e faz referência à voz da criança, apontando preocupação em ouvir o que ela tem a dizer, enfatizando, sobretudo, que ela não quer se posicionar quanto à decisão, requerendo proteção para que um terceiro decida por ela. Lago, Amaral, Bosa, \& Bandeira (2010) apresentam uma revisão sistemática sobre os principais instrumentos psicológicos nacionais e internacionais concernentes à avaliação das relações entre pais e filhos destacando a preocupação com a qualidade desse vínculo. Assim, essas autoras propõem uma maneira de se obter informações para subsidiar a tomada de decisão em casos que envolvem mudanças na estrutura e organização familiar motivadas por separação/divórcio.

$\mathrm{Na}$ esfera internacional, os estudos nessa área vêm se intensificando há mais de vinte anos e, cada vez mais, as investigações têm mostrado a relevância em ouvir a voz da criança, atentando-se para os seus diferentes pontos de vista e o contexto familiar em que está inserida (Birnbaum \& Saini, 2008; Cashmore \& Parkinson, 2008; Saywitz, Camparo, \& Romanoff, 2010). Enquanto algumas esperam decidir, outras preferem apenas fornecer suas opiniões e preferências; há as que optam por manifestar-se quanto aos desajustes no processo de separação versus resiliência e adaptação à dinâmica das novas famílias; outras, ainda, precisam de uma casa como referência, diferentemente daquelas que necessitam relacionar-se 
com ambos os pais. O principal aspecto é considerar a voz da criança na tomada de decisão e não apenas seguir a perspectiva dela na crença de estar atendendo ao seu melhor interesse. É necessário considerar a tensão entre a sua participação e a sua proteção, evitando considerá-la como vítima dos desentendimentos entre os pais depois da separação Assim, ao ouvir a criança, observa-se haver, na interação entre ela e seus pais, preferência ou rejeição, com sentimento de ambivalência; reação de passividade e retraimento diante de situações de conflito ou se está triangulada (Agulhas \& Anciães, 2014; Birnbaum \& Saini, 2012; Cashmore, 2010; Cashmore \& Parkinson, 2008; Cashmore \& Parkinson, 2009; Ferreira, 2008; Pereira \& Matos, 2008; Saywitz et al., 2010; van Nijnatten \& Jongen, 2011). Sob essa ótica, a criança, ao participar da argumentação, reflexão e tomadas de decisão em conjunto, deixa de ser invisível, tornando-se sujeito de direitos, tendo validado e respeitado o seu ponto de vista (Costa \& Miragem, 2012, Skjørten, 2013). Portanto, o essencial em se ouvir o conteúdo de sua fala é o significado de sua expressão, que envolve o reconhecimento da criança como sujeito digno, com necessidades, que merece confiança no desenvolvimento da ascensão de sua autonomia na articulação entre o seu mundo interno e externo (Cashmore, 2011; Costa, Penso, Legnani, \& Sudbrack, 2009; Minuchin, 1990; Minuchin \& Fishman, 1990; Minuchin, Nichols, \& Lee, 2009; Santa Rosa et al., 2013).

\section{Método}

A presente investigação pautou-se na pesquisa qualitativa, que utiliza a interpretação como fundamento (Bauer, Gaskell, \& Allum, 2010; Flick, 2009). Sem perder de vista as interações familiares, a pesquisa aqui relatada privilegiou a entrevista apenas com a criança. Assim, a análise parte do olhar que ela traz do contexto familiar, observado no momento da avaliação psicossocial durante a tramitação do processo de disputa de sua guarda e regulamentação de visita na Justiça. A pesquisa qualitativa busca explorar e entender o 
significado de algum problema atribuído por indivíduos ou grupos. As informações foram coletadas no ambiente dos participantes, de onde emergiram as questões e os procedimentos, tendo sido construída, de modo indutivo, a análise e a interpretação do significado dessas informações, produzindo-se novos conhecimentos (Creswell, 2010; Flick, 2009).

\section{Contexto}

A pesquisa ocorreu em um Tribunal de Justiça, onde há uma equipe composta por psicólogos e assistentes sociais que realiza estudo psicossocial com as famílias encaminhadas pelo juiz. Os atendimentos foram organizados por esses profissionais, com os diferentes subsistemas da família, incluindo o acolhimento individual da criança que estava em disputa. Usou-se a entrevista para a obtenção das informações. A pesquisa foi realizada quando os profissionais atenderam somente a criança, logo após a ouvirem sobre a disputa.

\section{Participantes}

O principal indicativo para a seleção dos casos para a pesquisa foi o fato de a dinâmica familiar evidenciar intenso conflito, crônico ou não, principalmente, entre o par parental (Johnston, Roseby, \& Kuehnle, 2009). Os participantes da pesquisa foram 11 crianças pertencentes a nove famílias que fizeram parte do estudo psicossocial, com idades que variaram entre 8 e 11 anos. Para melhor entendimento, os dados de qualificação das crianças estão descritos na tabela 1 , a seguir. 


\section{Tabela 1}

Informações das Crianças Participantes da Pesquisa e da Ação Judicial por Família

\begin{tabular}{|c|c|c|c|c|c|c|c|c|}
\hline \multirow[b]{2}{*}{$\begin{array}{l}\text { Famí- } \\
\text { lia }\end{array}$} & \multicolumn{4}{|c|}{ Informações sobre as crianças } & \multicolumn{4}{|c|}{ Ação judicial } \\
\hline & Nome & $\begin{array}{l}\text { Idade/ } \\
\text { sexo }\end{array}$ & $\begin{array}{l}\text { Ano } \\
\text { esco- } \\
\text { lar }\end{array}$ & $\begin{array}{l}\text { Reside } \\
\text { com }\end{array}$ & Tipo & $\begin{array}{l}\text { Movida } \\
\text { por }\end{array}$ & Contra & Motivo \\
\hline F1 & Jaspe & $\begin{array}{l}11 / \\
M\end{array}$ & $6^{\circ}$ & $\begin{array}{l}\text { Pai e } \\
\text { Irmã (13 } \\
\text { anos) }\end{array}$ & RDUE & Pai & Mãe & $\begin{array}{l}\text { Violência } \\
\text { interparental, } \\
\text { uso abusivo de }\end{array}$ \\
\hline & Ônix & $\begin{array}{l}8 / \\
M\end{array}$ & $3^{\circ}$ & $\begin{array}{l}\text { Mãe e } \\
\text { irmã (4 } \\
\text { anos) }\end{array}$ & & & & $\begin{array}{l}\text { álcool e } \\
\text { negligência dos } \\
\text { filhos. }\end{array}$ \\
\hline F2 & Jasmim & $\begin{array}{l}9 / \\
\mathrm{F}\end{array}$ & $3^{\circ}$ & $\begin{array}{l}\text { Mãe e } \\
\text { irmão } \\
(13 \\
\text { anos) }\end{array}$ & GR & Mãe & Pai & $\begin{array}{l}\text { Mãe suspeita de } \\
\text { abuso sexual da } \\
\text { filha na casa } \\
\text { paterna por } \\
\text { enteados. }\end{array}$ \\
\hline F3 & Ágata & $\begin{array}{l}10 / \\
\mathrm{F}\end{array}$ & $5^{\circ}$ & $\begin{array}{l}\text { Mãe e } \\
\text { avós } \\
\text { mater- } \\
\text { nos }\end{array}$ & RV & $\begin{array}{l}\text { Avós } \\
\text { paternos }\end{array}$ & Mãe & $\begin{array}{l}\text { Visitas do pai à } \\
\text { filha suspensas } \\
\text { judicialmente } \\
\text { por abuso } \\
\text { sexual } \\
\text { comprovado. }\end{array}$ \\
\hline F4 & Mirtilo & $\begin{array}{l}9 / \\
\mathrm{M}\end{array}$ & $3^{\circ}$ & $\begin{array}{l}\text { Mãe, } \\
\text { compa- } \\
\text { nheiro e } \\
\text { um } \\
\text { irmão } \\
\text { unilate- } \\
\text { ral (6 } \\
\text { anos) }\end{array}$ & $\mathrm{AG}$ & $\begin{array}{l}\text { Avós } \\
\text { maternos } \\
\text { mãe e pai }\end{array}$ & Não há & $\begin{array}{l}\text { Benefícios em } \\
\text { plano de saúde } \\
\text { e bolsa de } \\
\text { estudos para } \\
\text { língua } \\
\text { estrangeira. }\end{array}$ \\
\hline F5 & Berilo & $\begin{array}{l}8 / \\
M\end{array}$ & $2^{o}$ & $\begin{array}{l}\text { Mãe e } \\
\text { irmã (14 } \\
\text { anos) }\end{array}$ & $\mathrm{RV}$ & $\begin{array}{l}\text { Avó } \\
\text { paterna }\end{array}$ & Mãe & $\begin{array}{l}\text { Pai falecido } \\
\text { após a } \\
\text { separação } \\
\text { conflituosa. }\end{array}$ \\
\hline F6 & Yacón & $\begin{array}{l}9 / \\
\mathrm{M}\end{array}$ & $4^{o}$ & $\begin{array}{l}\text { Pai e } \\
\text { compa- } \\
\text { nheira }\end{array}$ & RV & Pai & Mãe & $\begin{array}{l}\text { Acusação de } \\
\text { maus tratos } \\
\text { físicos e } \\
\text { psicológicos } \\
\text { durante as } \\
\text { visitas na casa } \\
\text { materna. }\end{array}$ \\
\hline F7 & $\begin{array}{l}\text { Esme- } \\
\text { ralda }\end{array}$ & $\begin{array}{l}10 / \\
\mathrm{F}\end{array}$ & $5^{\circ}$ & $\begin{array}{l}\text { Mãe, } \\
\text { avó e tio } \\
\text { mater- } \\
\text { nos }\end{array}$ & $\mathrm{RV}$ & Mãe & Pai & $\begin{array}{l}\text { Pedido de } \\
\text { suspensão das } \\
\text { visitas por } \\
\text { acusação de } \\
\text { abuso sexual } \\
\text { pelo pai e }\end{array}$ \\
\hline
\end{tabular}




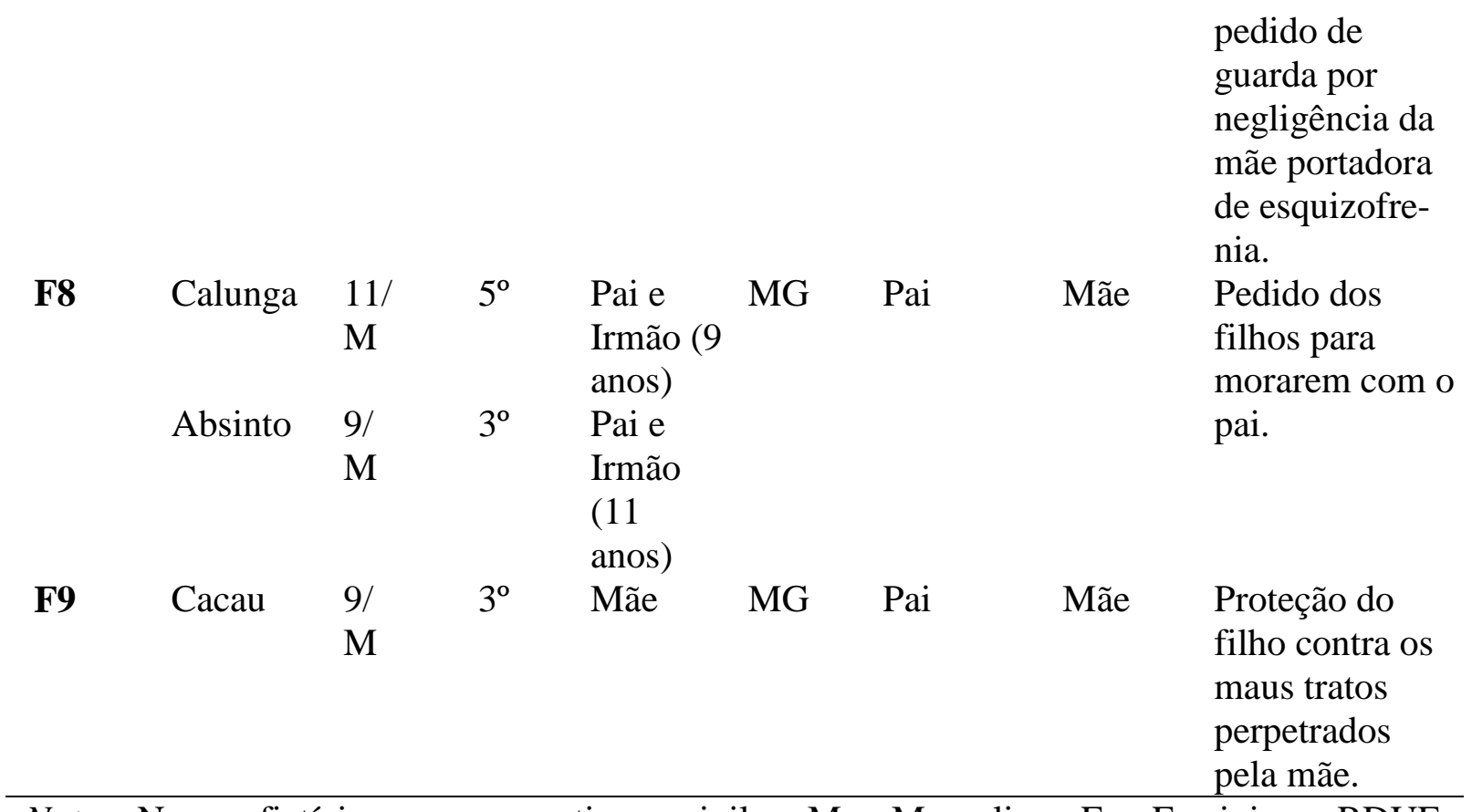

Nota: Nome fictício para garantir o sigilo. $\mathrm{M}=$ Masculino $\mathrm{F}=$ Feminino; $\mathrm{RDUE}=$ Reconhecimento e Dissolução de União Estável; GR= Guarda e Responsabilidade; AG= Acordo de Guarda; RV= Regulamentação de Visita; MG= Modificação de Guarda.

\section{Instrumentos}

Para a realização da entrevista, foi utilizado um roteiro que funcionou como guia para obter-se informações sobre as expressões da criança. Esse roteiro englobou os seguintes aspectos com ênfase na percepção da criança: o motivo de estar na Justiça, as histórias contadas concernentes às suas percepções e vivências no contexto familiar e as concepções sobre o seu sofrimento representadas por meio de desenhos. Para tanto, pediu-se que, em uma folha em branco, ela desenhasse as suas preocupações sobre o conflito familiar envolvendo a disputa de guarda e, posteriormente, fizesse outro desenho, representando as soluções em relação às preocupações apontadas (Puviani, 2011). Para essa autora, o desenho torna visível o mundo interno que está obscuro, relacionando-o com o exterior na comunicação de emoções e sentimentos, tomando-o como autorrevelação, integrando o verbal e o não verbal. 


\section{Procedimentos}

As informações foram coletadas durante a realização do estudo psicossocial, concomitante ao período em que as ações referentes à disputa de guarda, regulamentação de visita, modificação de cláusula (de guarda e de visita) foram tratadas, bem como a dissolução de união estável e divórcio litigioso que envolveram guarda e visitação dos participantes entrevistados. A coleta ocorreu durante os meses de novembro e dezembro de 2013.

As salas onde as entrevistas foram realizadas estavam equipadas com material lúdico (jogos e brinquedos), além de material de apoio (cadeiras e mesa) com as medidas apropriadas para a criança. As entrevistas tiveram a duração aproximada de 40 minutos e foram gravadas em áudio, que foram posteriormente transcritas. O conteúdo foi analisado na modalidade temática apontada por Minayo (2014) obtendo-se núcleos de sentido, aos quais foram atribuídos significados, denominados de subnúcleos.

\section{Cuidados Éticos}

Para a realização da pesquisa, o projeto foi submetido ao Comitê de Ética em Pesquisa conforme resolução do CFP 016/2000 em que a aprovação incluiu termo de compromisso pelo responsável do Tribunal de Justiça, e os Termos de Consentimento Livre e Esclarecido (TCLE) para o responsável da(s) criança(s) e o Termo de Assentimento na forma oral para que a criança pudesse participar livremente da pesquisa.

\section{Resultados e Discussão}

A partir da análise das informações coletadas em relação à expressão da criança, destacaram-se três núcleos de sentido: 1 . A Justiça é que decide; 2 . O juiz é quem decide; 3. Processo de reflexão. 


\section{"Um Fórum é pra Decidir as Coisas": A Justiça é que Decide}

A maior parte das crianças, isto é, oito das 11, evidenciou reconhecer e identificar a razão de estar naquele local. Cita-se como exemplo, Jaspe: É pra decidir se eu fico com o meu pai ou com a minha mãe. E aqui é um Fórum, tipo do juiz. Pra decidir as coisas. Jaspe expressou entender não ser possível morar com ambos os pais. A separação parental estava clara para ele. Assim, havia o entendimento de que a decisão seria feita por um terceiro, o “juiz", que decidiria "as coisas". Jaspe se reconhece como parte integrante dessas "coisas" e, por isso, confia e aguarda a decisão que será determinada para "ficar" com o pai ou com a mãe. A literatura nessa área não destaca que a criança confia na decisão da Justiça, porém evidencia a necessidade da participação dela nos assuntos que lhe são pertinentes, de modo a ser respeitada no que tem a dizer, bem como ter o seu ponto de vista considerado nas tomadas de decisão (Birnbaum, Bala, \& Cyr, 2011). Além disso, a criança espera que o resultado seja, de algum modo, equilibrado, embora reconheça que os seus interesses podem não ser os mesmos dos seus pais (Cashmore \& Parkinson, 2008). A crítica, entretanto, é feita quando, na Justiça, ao se buscar o melhor interesse da criança e, quando não se tem clareza em como obtê-lo, pode-se intensificar o litígio e fortalecer a dependência da apreciação judicial (Fuhrmann \& Zibbel, 2012), e a criança, ao aguardar a decisão do tribunal, evidencia reconhecer sua dependência dessa instância na garantia de sua proteção e bem-estar.

A pesquisadora, ao perguntar para as crianças, durante a entrevista, o que eles estavam fazendo naquele local (fórum), Absinto apresentou a seguinte explicação: Pra decidir com quem a gente vai ficar... O mesmo é percebido na fala de Cacau: Pra decidir quem vai ficar com a minha guarda. Jasmim afirma: Eu sei que o meu pai tá brigando pela guarda da gente [dela e dos irmãos]. Ela acrescenta que a guarda é Uma aposta. Há um jogo entre o pai e a mãe, e a Justiça é que irá decidir quem ganha. A criança sabe que ela faz parte desta aposta e, tal como Jaspe, confia que será ouvida e deixa o poder da decisão a cargo da Justiça. Mirtilo: Eu tô aqui porque a minha vó [materna] vai pegá a minha guarda. (...) Porque eu pedi pra 
ela. Porque deu vontade de morá com ela. A família atendeu ao seu pedido e ajuizou a ação de guarda (tabela1). Mirtilo estava com "vontade" de morar com a avó. Ele teve a acolhida dela e anuência e apoio da mãe e do pai. A família ouviu-o e espera que o poder judicial também o faça. Para Ônix, o motivo de estar na Justiça é: Para falar dessas coisas assim... de mãe e de pai. Essas coisas assim. A Justiça é um local em que será ouvido no que tem a dizer e acredita que alguém irá escutá-lo. Assim, ele confia em revelar "coisas" relativas à mãe e ao pai, que envolvem suas preocupações e desejos.

Berilo, por sua vez, expressou: Eu não sei por que eu tô aqui direito. (...) quando alguém tenta disputar pela coisa que ela quer, aí não quer deixar a outra [ganhar], ela quer que ganha [a disputa]. A criança não tem clareza sobre o motivo pelo qual está na Justiça. Não consegue correlacionar a sua presença na Justiça com a regulamentação de visitas requerida pela avó paterna contra a sua mãe (tabela 1). Entretanto, reconhece que há algo de impeditivo na interação entre elas e entende que será decido fora do âmbito familiar, sendo que, inevitavelmente uma delas irá "ganhar" a disputa. Yacón também tem dúvidas em relação ao significado de sua presença naquele local: [É] Por que minha mãe me bateu? Do João ficar me batendo, de várias coisas... (...) de várias coisas mais. Sei lá, tem muitos... [motivos para estar na Justiça]. Yacón, ao verbalizar suas dúvidas, revela preocupações, incômodos e desconfortos que vivencia em seu ambiente familiar. Embora não tenha clareza do que a Justiça quer dele, reconhece estar implicado, de alguma maneira, no processo de mudanças que está por vir com a interferência da Justiça, uma vez que os seus pais recorreram a essa instância (tabela 1). Assim, Yacón espera que a Justiça o ouça e considere o que tem a dizer, tanto quanto os seus pais. É direito da criança ser informada sobre o que está acontecendo em relação às mudanças que a envolvem e pronunciar-se, sentir-se motivada a fazê-lo, bem como ter o conhecimento das implicações de sua participação nesse contexto (Birnbaum et al., 2011; Birnbaum \& Saini, 2012; Byrnes, 2011). Dessa maneira, contribui 
para o desenvolvimento da autonomia da criança participar-lhe as mudanças que poderão ocorrer em sua vida e o envolvimento da Justiça em tomadas de decisões que lhe dizem respeito, pois ela é parte integrante e ativa na relação com a família e a Justiça.

Este núcleo assinalou que a maior parte das crianças entrevistadas tinha conhecimento de que se tratava de contexto de decisão. As crianças apontaram que, quando encontram espaço favorável para contar sua história, elas o fazem, pois se sentem respeitadas em seus recursos emocionais e capacidades para se manifestarem em assuntos dos quais fazem parte (Birnbaum et al., 2011). Elas acreditam que têm contribuição a oferecer na decisão a ser tomada pela Justiça e indicaram que se a conjuntura lhes for favorável, se a Justiça se dispuser a ampliar a valorização de sua expressão como sujeito de direitos (Costa, et al, 2009) e, considerando sua condição de vulnerabilidade em razão da idade (Santa Rosa et al., 2014), poderão tornar-se visíveis (Costa \& Miragem, 2012) na transação entre a autonomia e a interdependência com os adultos que estão como seus responsáveis (Minuchin, 1990, Minuchin \& Fishman, 1990; Minuchin et al., 2009). Ademais, ouvir e considerar o ponto de vista da criança, além de significar respeito pela sua autonomia e dignidade, é também, uma maneira de incluí-la na tomada decisão e sua participação possibilita não apenas que ela avalie sobre as repercussões da decisão judicial em sua vida, mas também, contribui para decisões mais coerentes com as suas necessidades e para a viabilidade dos acordos judiciais (Santa Rosa et al., 2013).

\section{O "Bom Hábito": O Juiz é Quem Decide}

Neste núcleo, observou-se que das 11 crianças, cinco disseram que a disputa será decidida pelo juiz: Calunga, Ônix, Jaspe, Cacau e Berilo, sendo que outras três, Jasmim, Ágata e Absinto antes de reconhecerem que a decisão é do juiz, apontaram a sua implicação no contexto de decisão. Absinto: Não! [em discordância à reposta do irmão] "Nóis"! [ele e o 
irmão]. Eu acho que a gente! Se meu pai tiver um bom hábito, vai ficar com a gente! A criança reconhece que a decisão será do juiz, reconhece a competência do julgador, que tem conhecimento e autoridade para decidir, mas apresenta os "hábitos do pai" e espera que o juiz avaliará a qualidade destes "hábitos" (Santa Rosa et al., 2013). Ela sabe que a decisão se relaciona com as atitudes, as habilidades parentais. A expectativa de Absinto é a de que, se o juiz concluir de modo favorável ao "bom hábito" paterno, a decisão poderá ocorrer em direção ao que ele deseja, ou seja, o pai vai ficar com ele e o irmão, conforme o pedido que fizeram ao pai (tabela 1). Nesta fala, observa-se inversão na estrutura familiar (Minuchin, 1990), pois Absinto e o irmão deverão ficar com o pai. Ele e o irmão estão ali para fazer referência aos "bons hábitos" do pai, evidenciando seu interesse em participar da decisão, em ser ouvidos pela instância judicial. Esperam que o "bom hábito" que percebem existir no pai, seja observado pelo juiz e, assim, poderão ter sua solicitação atendida. Desse modo, a criança sente-se estimulada a dizer o que pensa, a expressar seus desejos em instância que a acolhe e oportuniza sua voz. O pai se sentiu encorajado com o pedido dos filhos, transmitiu-o ao juiz e o formalizou por meio de uma ação processual contra a mãe, que ele espera seja analisada. A criança compreende essa organização e espera que suas demandas sejam ouvidas a fim de sentir-se protegida. Segundo Ausloos (1996), a família tem competência para gerir seus problemas, suas dificuldades, porém, em certas ocasiões, por não saber como utilizá-la, recorre a outras instâncias, fora do seu sistema; e ao buscar a Justiça, fornece os elementos, as informações pertinentes à tomada de decisão (Santa Rosa et al., 2013).

Ágata esclareceu: Acho que o que eu tenho para fazer eu já fiz: falar que eu queria voltar a ver minha avó, meu avô, queria ir para a casa deles. Tudo isso eu acho que eu já fiz. Agora [é] só esperar mesmo a decisão do juiz. À semelhança das crianças já citadas, ela também confia e espera a decisão. Ágata considera ter feito a sua parte, isto é, externou o seu 
desejo para os avós paternos que não conseguiram acordo com a mãe e recorreram à Justiça solicitando a regulamentação de visita (tabela 1).

Quanto aos desenhos, por não ser possível incluí-los neste artigo, optou-se por descrevê-los, bem como as falas deles decorrentes ${ }^{4}$. O primeiro desenho feito por Ágata representou o problema (Anexo 27): Uma carinha triste, são os olhos. (...) Aí o nariz, e a boca triste. (...) Aí esse aqui eu fiz meio diferente, na verdade esses aqui são os olhos, os dois tracinhos... (...) Esse aqui é o nariz, e essa aqui é a boca. (...) Aí eu fiz os olhos fechados, aí a boca e o nariz. Ágata buscou tornar visíveis seus sentimentos em relação à falta do convívio com os avós. Quando se refere à "agonia", palavra escrita no desenho, a expressão retratada evidencia algo que a perturba, a aflige e a boca fechada demonstra dificuldade para verbalizar o que sente. Os traçados acentuam os sentimentos verbalizados. Ao referir-se à saudade, desenha uma casa, repetindo a expressão da "agonia". A cor marrom do traçado da casa, representa a terra, elemento da natureza que indica acolhimento, reproduzindo a sensação que tinha nas ocasiões em que estava em visita aos avós. A terceira carinha traz em destaque a palavra tristeza, como a indicar sua incursão na sensação de saudade manifestada anteriormente. No segundo desenho, a solução (Anexo 28), Ágata propõe: Eu, minha avó... nós duas... se vendo quando a gente quisesse... em um lugar feliz... Ágata representou uma solução possível de ser alcançada. Em seu imaginário, a felicidade está em conviver com os avós em um lugar aberto, em contato com a natureza, onde há calor, colorido e beleza, pois ela compreende não ser possível encontrar com os avós na casa deles (tabela 1).

Calunga, ao se pronunciar sobre a quem cabe a decisão ele diz: $O$ juiz! Contudo, esclareceu compreender como as informações chegarão até ele: Pela entrevista [feita pelo psicólogo]. E explicou: A entrevista [é] pra ver se eu tô bom na escola, se eu tô bem lá, se tô tirando notas boas, essas coisas assim... Jasmim indicou a quem cabe a decisão: Nós três (ela

\footnotetext{
${ }^{4}$ Entretanto, para fins da tese, os anexos foram mencionados vinculando-os à descrição dos desenhos.
} 
e os dois irmãos). (...) O juiz? (...) O assistente social. A criança entende que não está falando diretamente com o juiz, mas sente-se acolhida e respeitada pelo profissional que está diante dela. Sente-se aceita e confiante em expressar seus sentimentos e emoções, suas dúvidas, preocupações e em explicitar seus pontos de vista (Monteiro, 2010; Santa Rosa et al., 2013; UNICEF, 1990). Acredita que sua opinião será encaminhada ao juiz para ser analisada por ele que tem competência e autoridade para decidir em favor do seu bem-estar e proteção no atendimento e preservação dos seus direitos fundamentais (Santa Rosa et al.).

Este núcleo demonstrou que a criança é autônoma em expressar sua opinião, mas depende de um adulto que decida por ela, lhe dê segurança e exerça autoridade sobre ela (Minuchin, 1990; Minuchin \& Fishman, 1990). A confiança no juiz evidencia que ela quer participar dos assuntos que lhe dizem respeito, revelando os seus pontos de vista, reconhecendo-se como sujeito de direitos e que requer a proteção de um terceiro que decidirá em seu benefício, mesmo que suas expressões sejam mediadas por profissionais especializados (Byrnes, 2011; Cardoso \& Costa, 2014; Cashmore \& Parkinson, 2008). Assim sendo, as suas expressões serão transmitidas ao juiz pelos profissionais com conhecimento específico nesta área, pois o magistrado não tem o conhecimento adequado sobre desenvolvimento infantil e nem sobre a dinâmica das interações familiares (Santa Rosa et al., 2013). Portanto, a criança, ao ser ouvida por profissional preparado para esse fim (Agulhas \& Anciães, 2014; Huss, 2009), sente-se segura, convicta de que seus pontos de vista, próprios e únicos, estão sendo incluídos na tomada de decisão, e que seus interesses estão sendo cuidados, diferenciando-os do discurso familiar conflituoso (Foot, 2011; Pereira \& Matos, 2011). 


\section{"Pode Acontecer Isso"? O Processo de Reflexão}

Este núcleo apontou que enquanto a criança aguarda a sentença do juiz ela faz reflexões a respeito de suas expectativas sobre a decisão. Absinto: [Por] Que meu pai, ele é uma boa pessoa, cuida da gente e dá carinho. Ágata: Mas se ele (juiz) achar que ela (avó) não vai fazer isso de novo, (...) Ele (juiz) poderia deixar. (...) Dependendo do que ele decidir, pode [permitir as visitas]. Cacau: Não sei! Ônix: Pode ser assim? Nós dois (ele e o irmão) [vamos] ficar com o meu pai e aquelas duas (irmãs) podem ficar com a minha mãe? Pode acontecer isso? (...) Eu queria morar com a minha mãe, demais, demais! No desenho representando o problema (Anexo 21A) Yacón: Eu só quero que ele (juiz) descubra quem me bateu! A criança confia na decisão judicial e espera ter sua voz valorada ainda que não saiba o que dizer ou sua fala mostre-se ambígua (Graham \& Fitzgerald, 2010) com pensamentos contraditórios em razão do medo de ser abandonada (Agulhas \& Anciães, 2014; Minuchin, 2009). Além disso, tem esperança de que o juiz dê respostas relacionadas a vivências que tem na família por não conseguir obtê-las de seus pais, pois acredita que ele as fornecerá para diminuir a sua ansiedade (Santa Rosa et al., 2014).

Yacón: Sandália... (...) Uma sandália, eu, é com essa daqui que ela (mãe) me bateu! (...) Aqui. (apontando no desenho (Anexo 21B), ele está entre o pai e a mãe) (...) [com a sandália na mão] e o meu pai também! (...) é que eu não sei quem me bateu! A criança representou a sua principal preocupação: quem bateu nele quando tinha cerca de quatro anos de idade? Para Yacón, o juiz irá desvendar algo importante, que não consegue saber com o pai e a mãe. Embora o juiz tenha os subsídios necessários com o apoio de outras áreas da ciência (Monteiro, 2010), há questões de impossibilidade da certeza, pois as opiniões científicas podem também ser insuficientes e não responder suas dúvidas (Santa Rosa et al., 2013). Já, no desenho da solução, a pesquisadora pergunta: Que solução você dá pra essa situação que te preocupa? Yacón aponta: No Tribunal. (...) Tribunal aqui (apontando para o desenho Anexo 23), minha mãe, meu pai e eu aqui e aqui a minha mãe. Representa a mãe, o pai e ele, 
sentados perante o juiz. O julgador está postado em sua tribuna com um martelo na mão para, ao som da ferramenta que bate sobre o móvel, acolhê-lo e oferecer uma resposta que espera acalmá-lo. Nesse momento, a criança sente-se segura, todavia, é preciso explicitar as limitações inclusive para ela quando necessário (Santa Rosa et al., 2013).

Relativamente às expectativas sobre a mudança familiar com a decisão judicial, as crianças explicitam suas reflexões. Absinto: Mas depois que a gente... se a gente for querer voltar a morar com ela (mãe), ela vai voltar a brigar. Jaspe: Acho que eu posso ficar doente porque ela bebe muito, aí... (...) Porque o lugar não é bom também. E aí ela ia sair, porque ela sai muito. Ia deixar a gente sozinho... (...) E também ia me deixar...como é que se fala? Chateado! (...)Também porque ela bebe muito. Aí... ela fica... é... estressada... xinga muito! Ônix: Eu estou com medo de morar com o meu pai, porque eu quero morar com a minha mãe! Elas assinalam os seus temores e confiam no contexto para dizer o que sentem, esperam ser ouvidas e querem ser protegidas e amparadas pela família que, na Justiça, está sendo avaliada na qualidade das interações e competência parental no atendimento de suas necessidades (Agulhas \& Anciães, 2014; Pereira \& Matos, 2011; Santa Rosa et al., 2014).

Os desenhos destacaram, com clareza, as preocupações e as soluções (Puviani, 2011) apresentadas pelas crianças no atendimento aos seus interesses. Nos traçados de Calunga, estão suas preocupações (Anexo 8): É, eu estou triste e aqui eu estou alegre. (...) triste com a minha mãe. (...) Isso aqui é a boca aberta, assim... (...) Aqui são os olhos fechados e tristes. (...). Com o meu pai. (...) Os olhos abertos... (...) E sorridente... Calunga torna visível a sua ambivalência de sentimentos em relação a ter que fazer a escolha entre a mãe e o pai, que representa com um coração dividido ao meio (Agulhas \& Anciães, 2014). De um lado, apresenta a tristeza em relação à mãe e a alegria em relação ao pai. Ao mesmo tempo, é a representação de si mesmo na expressão de sua ambivalência sentindo-se dividido. Nas reflexões feitas por Calunga quando desenhou a solução (Anexo 9), obteve-se a seguinte 
conclusão: Aqui ó, [no desenho] minha mãe está longe e meu pai tá perto de casa, saiu agora. Aqui meu pai está gritando: "Que tal a gente sermos amigos?”. Ela: "Sim!”. Tá gritando de longe. (...) A casa que meu pai saiu e a garagem. Aqui são as nuvens e o arco-íris e o sol ensolarado. Meu pai, eи e meu irmão. E meus dois coelhinhos. (...) Aí dentro (da casa)! Calunga consegue manifestar a solução que imagina ser possível e passível de ocorrer. Sente-se confiante em externar seus pensamentos em espaço protegido, diante do profissional que o acolhe. Em seu desenho, representa os pais tornando-se amigos por meio de uma proposição paterna que é aceita pela mãe. Ele reconhece, na separação de seus pais, a divisão de si mesmo ao desenhar o seu coração dividido. Porém, ao representar a construção de uma relação amistosa entre pai e mãe, consegue inteirar-se, completar-se. Descreve a composição da casa como um local seguro e acolhedor. Evidencia vida e movimento no ambiente ao incluir dois pequenos animais de que gosta de cuidar e de brincar (Puviani, 2011).

As informações foram reveladas pela criança integrando a fala e os desenhos, ela comunicou seu mundo interno repleto de expressões não verbais e imagens que concretiza por meio dos traços sobre as folhas em branco e conseguiu estabelecer o encontro de seus sentimentos (Andolfi, 1991; Puviani, 2011). As crianças sentiram confiança para expressar suas reflexões de modo autônomo, reconhecendo depender do adulto para que seus pensamentos e ansiedades (Minuchin, 1990; Minuchin \& Fishman, 1990; Minuchin et al., 2009) sejam expressos em um contexto no qual deverão ser tomadas decisões que as envolvem. Em suas reflexões, reconhecem que podem acontecer decisões diferentes das que esperam, porém percebem haver espaço para expressar suas preocupações e as perspectivas que vislumbram como solução para o impasse familiar no qual se inserem. Os efeitos da dialética familiar atingem a criança quanto a sua volição, sendo importante considerar sua opinião, porém tomando o cuidado para não incumbi-la da decisão (Cardoso \& Costa, 2014; Cashmore, 2010; Cashmore, 2011; Cashmore e Parkinson, 2008; Cashmore e Parkinson, 
2009; Costa, et al., 2009; Costa \& Miragem, 2012; Ferreira, 2008; Pereira \& Matos, 2008; Saywitz et al., 2010; van Nijnatten \& Jongen, 2011).

\section{Considerações Finais}

O presente artigo buscou analisar como a expressão da criança sobre seu sofrimento, durante o processo de avaliação psicossocial nos casos de disputa de guarda e regulamentação de visita, e como a audição do seu ponto de vista relativamente ao processo pode significar a possibilidade de a decisão judicial ser mais assertiva em relação ao que importa aos seus interesses.

Os resultados demonstraram que a criança tem clareza do significado do contexto judicial, quer ser ouvida e ter a sua opinião considerada e respeitada como um sujeito de direitos (Monteiro, 2010; Santa Rosa et al., 2013). Reconhece ser dependente de um adulto que decidirá por ela, porém espera que a decisão a ser tomada na Justiça atenderá seus anseios, tornando-a visível (Costa \& Miragem, 2012) como participante ativa, evitando ser vista apenas como vítima, valorizando suas capacidades, convicta de que terá os seus pontos de vista incluídos, a despeito do discurso dos adultos que destacam o contexto familiar beligerante do qual faz parte (Foot, 2011; Pereira \& Matos, 2011; Ribeiro, 2010).

Percebeu-se que a criança tem autonomia para informar na Justiça o que entende ser pertinente conforme o seu ponto de vista. Entretanto, reconhece depender dos adultos para sentir-se protegida e segura na avaliação do que é melhor para ela. Portanto, a criança se reconhece atendida nos direitos de participação e de proteção no âmbito da disputa de guarda e regulamentação de visita, evidenciando necessitar de espaço acolhedor que lhe proporcione respeito e inclusão ao ser ouvida em seu ponto de vista (Birnbaum \& Saini, 2012; Cardoso \& Costa, 2014; Cashmore, 2011; Santa Rosa et al., 2014). 
A criança reconhece, também, depender da decisão do juiz que tem a intermediação de profissional especializado que a ouça, acolha e se disponibilize a ressaltar suas emoções e sentimentos nesse âmbito. Ela confia que o profissional encaminhará os seus pontos de vista para o juiz, que irá decidir de modo a garantir o atendimento de suas necessidades, que inevitavelmente envolvem modificações na configuração familiar. Os resultados apontaram que a criança quer ser considerada e respeitada em suas necessidades individuais, que são próprias e únicas, (Birnbaum \& Saini, 2012) bem como valorizada na qualidade de sua interação com a família no reconhecimento das habilidades e competências parentais (Ausloos, 1996; Fuhrmann, \& Zibbel, 2012; Monteiro, 2010; Minuchin, 1990; Pereira \& Matos, 2011; Santa Rosa et al., 2013; UNICEF, 1990).

Pôde-se observar ainda que a criança torna-se receptiva e confiante quando lhe é oferecido espaço acolhedor e seguro, conseguindo externar suas preocupações, receios e incertezas e apontar soluções que lhe pareçam viáveis e que atendam ao seu bem-estar. Ficou evidenciado que, com sua participação, a criança contribui, de modo único e particular, no subsídio de informações para a decisão na Justiça em favor do seu bem-estar. Demonstrou compreender a interação entre o juiz, que avalia e decide, e os profissionais que a acolhem no fornecimento de subsídios para a tomada de decisão, no intuito de garantir a sua proteção. Os resultados demonstraram ainda que a Justiça, ao incluir o ponto de vista da criança, irá atendela em seus anseios, favorecendo e facilitando a aceitação das mudanças na família, decorrentes da decisão judicial, tornando os acordos mais viáveis e direcionados ao que importa para o seu saudável desenvolvimento (Birnbaum \& Saini, 2012; Cashmore, 2011; Graham \& Fitzgerald, 2010; Santa Rosa et al., 2013; Santa Rosa et al., 2014). 


\section{CONSIDERAÇÕES FINAIS}

Trabalho no SERAF desde 1996. Esta tese originou-se de questionamentos que surgiram na minha atuação profissional em processos de disputa de guarda. Assim, sob a orientação da professora e doutora Liana, procurei reconhecer o sofrimento da criança neste contexto durante a avaliação psicossocial. Nessa perspectiva, a presente investigação foi norteada por dois pontos principais. O primeiro é referente ao sofrimento da criança. Ela consegue se expressar e comunicar seu sofrer, indicar o que acredita ser seu e o que entende ser inerente à dependência dos pais, conseguindo transitar entre autonomia e interdependência. O segundo relaciona-se à expressão do sofrimento da criança na Justiça que, ao revelar sua dor, ajuda aos atores da decisão judicial a privilegiarem e decidirem a partir do melhor interesse dela.

O referencial teórico, com base no Pensamento Sistêmico, na Terapia Familiar Sistêmica e na Psicologia Jurídica, que fundamentou a análise da pesquisa, foi fundamental para perceber-se que há muito a ser produzido no campo nacional. No âmbito internacional, observa-se que as publicações dos estudos estão mais avançadas, pois há permanente preocupação em adequar as teorias à realidade da prática profissional, conjugando-se às constantes mudanças das políticas públicas para que sejam mais condizentes com a realidade da criança. Isso evidencia o trabalho que há para ser feito no intuito de que as crianças tenham seus direitos resguardados e sejam efetivamente consideradas sujeitos merecedores de respeito e dignidade.

Com relação ao sofrimento da criança, este estudo destacou, a partir da análise das informações obtidas, três núcleos de sentido: sentimentos que expressam o sofrimento, a origem e a superação. A pesquisa mostrou que a criança, ao ocupar o lugar de protagonista da própria história, é capaz de identificar os sentimentos que envolvem seu sofrer, a origem e as 
soluções que vislumbra para superá-lo, quando seus pais se separam/divorciam e há conflito interparental. Os sentimentos descritos envolvem tristeza, solidão, agonia, angústia, saudade, amor e raiva vivenciados durante as mudanças que ocorrem na separação/divórcio parental, agravados pelo permanente conflito interparental. Apesar do contexto conflituoso, a criança consegue desenvolver sua autonomia com vistas à autoestima e confiança para diferenciar-se da dependência que tem de seus pais. Busca a "verdade" a seu respeito, que significa a garantia de receber o amor dos pais, de não ser abandonada, de ser respeitada na expressão dos seus sentimentos e do amor que sente por eles. A literatura corrobora essa constatação, Birnbaum e Saini (2012), Cardoso e Costa (2014), Cashmore (2011), Johnston et al. (2009), Minuchin (1990), Minuchin et al. (2009) Santa Rosa et al. (2014), Sthal (2011).

Para a criança, a superação das dificuldades vivenciadas nesse momento, está no suporte dos adultos aos quais ela recorre para obter proteção e segurança, partindo de seus pais, passando por familiares, alcançando amigos, vizinhos, profissionais, e chegando à dimensão espiritual, tendo Deus como representante. Portanto, os primeiros resultados da presente investigação confirmaram a tese de que a criança, ao sentir-se em espaço confiável, expressa sua capacidade no anseio de superar o sofrimento no contexto de separação/divórcio parental que envolve conflito interparental na implicação de sua guarda. Com isso, a segunda tese também foi confirmada, pois os atores que avaliam a criança e sua família, e decidem na Justiça em relação a sua guarda, estarão mais próximo de suas reais necessidades, favorecendo acordos mais viáveis e efetivos, tal como apontam Birnbaum e Saini (2012), Cashmore (2011), Graham e Fitzgerald (2010), Santa Rosa et al. (2013), Santa Rosa et al. (2014). Assim sendo, constatou-se que os objetivos foram atingidos, pois foi possível conhecer o sofrimento da criança durante a avaliação psicossocial.

Quanto ao objetivo referente às estratégias utilizadas pela criança ao enfrentar seu sofrimento nesse âmbito, também foi alcançado. A pesquisa mostrou que o conteúdo do 
discurso expresso por ela revela que tem conhecimento de si mesma, de suas relações e do contexto em que se insere; aprendizado, relativamente a como lidar com os impasses que vivencia; e amadurecimento, como resultado do que conhece e aprende para abrandar seu sofrer em razão das mudanças oriundas da separação/divórcio conjugal e do conflito parental/familiar existente. Assim sendo, uma das estratégias de sobrevivência nesse contexto, é o fortalecimento dos vínculos de pessoas significativas para ela (pai, mãe, avós), bem como da fratria, quando há irmãos. No caso da relação fraternal, observou-se que o fortalecimento ou o enfraquecimento/distanciamento dependerá da interação entre a criança com seus pais e destes com cada um dos irmãos. Esses aspectos foram apontados por outros pesquisadores, Goldsmid e Féres-Carneiro (2007), Juras e Costa (2011a), Muniz e Féres-Carneiro (2012), Shelton e Harold (2007), Shumaker, Miller e Ortiz (2011), Silveira (2009), Simeón (2000). Para tanto, a criança atua como árbitro no equilíbrio das relações familiares, assegurando o bem-estar de todos, desistindo de escolher entre conviver com o pai ou com a mãe para ter a garantia do amor dos dois.

O presente estudo mostrou que a expressão da criança se evidencia por meio de sua voz na revelação de posicionamentos reflexivos mediante a conjuntura da qual faz parte. Ela compreende o significado do contexto judicial, quer ser ouvida e ter a sua opinião considerada e respeitada como um sujeito de direitos, tornando-se visível nesse âmbito. Com isso, a criança deixa de ser vista apenas como vítima, espera ser respeitada em suas necessidades individuais, que são próprias e únicas, valorizada em suas capacidades, convicta de que terá os seus pontos de vista incluídos, a despeito do discurso dos adultos que destacam o contexto familiar beligerante do qual faz parte. Essas constatações estão em conformidade com pesquisas anteriores, Birnbaum e Saini (2012), Costa e Miragem (2012), Foot (2011), Fuhrmann, e Zibbel (2012), Monteiro (2010), Pereira e Matos (2011), Ribeiro (2010), Santa Rosa et al. (2013). 
Assim, os avanços apontados pela presente pesquisa referem-se ao fato de a criança reconhecer que sua participação contribui, de modo único e particular, no subsídio de informações para a decisão na Justiça em favor do seu bem-estar. Ela compreende haver interação entre o juiz, que avalia e decide, e os profissionais que a acolhem no fornecimento de subsídios para a tomada de decisão para a garantia de sua proteção. Outro avanço é o fato de se perceber que a criança atua como mediadora para equilibrar as relações familiares para assegurar o bem-estar de todos, desistindo de escolher entre conviver com o pai ou com a mãe, mas tendo a certeza de que receberá o amor de ambos.

Destaca-se que o roteiro de entrevista e o desenho, nos moldes empregados nesta pesquisa, complementaram-se na obtenção das informações, mostrando-se eficientes para colher as expressões da criança em relação à voz, sofrimento e enfrentamento no contexto de disputa de guarda. Esses instrumentos poderão contribuir para acelerar o tempo utilizado na avaliação, agilizando o andar do processo no tribunal se forem incluídos na metodologia do trabalho psicossocial. Portanto, recomenda-se que sejam colocados nos procedimentos quando os profissionais realizarem a avaliação psicossocial em contexto de disputa de guarda com crianças entre 8 e 11 anos de idade, pois poderão ser úteis para privilegiar a expressão da criança nesse âmbito.

Com relação às futuras pesquisas, recomenda-se o estudo, a partir da percepção da criança, do vínculo entre pai e filho, mãe e filho nesse contexto, inclusive das crianças cujo pai ou mãe se recusa ou tem dificuldade em se manter vinculados a elas. Estudar esse aspecto poderá contribuir para que as intervenções dos profissionais sejam mais eficazes, bem como a decisão judicial em relação ao atendimento do melhor interesse da criança.

Outra possibilidade de pesquisa é identificar a competência parental antes, durante e depois da separação com o propósito de garantir o atendimento das necessidades da criança, o que envolve a coparentalidade na nova organização familiar, e vai contribuir para que as 
intervenções sejam focadas na orientação dos pais para a proteção dos filhos. Consequentemente, a decisão judicial terá mais elementos que favorecerão o bem-estar da criança.

Além disso, considera-se importante que, em investigações futuras, sejam incluídos participantes entre 0 e 6 anos de idade, porque nessa fase de desenvolvimento as crianças mostram-se mais vulneráveis, e em consequência, mais expostas a contexto de risco à sua integridade física e emocional. Inclua-se também a necessidade de estudar se há diferenças no sofrimento da criança entre meninos e meninas e em que medida elas ocorrem, de modo a aprofundar o conhecimento visando a atender especificamente suas reais necessidades.

Estas propostas de pesquisas podem ser vistas como limites da presente pesquisa. Acrescente-se, nesse âmbito, que o caminho escolhido para a obtenção das informações foi entrevistar a criança individualmente. Com isso, não se incluíram observações entre ela e sua família, nem se privilegiou um roteiro que abarcasse os subsistemas com seus pais ou avós. Essa estratégia foi utilizada pensando-se em preservar a criança de alguma situação de risco emocional que pudesse surgir no decorrer da entrevista.

Embora o tema disputa parental não seja novo, esta pesquisa evidenciou haver necessidade de publicações na área como uma maneira de se manter atualizadas as informações, visando à garantia do bem-estar da criança. Ademais, entende-se como imperativa a ampliação de conhecimento do profissional que atua em contexto psicossocial para que suas intervenções sejam mais efetivas, tanto em relação à criança e sua família, quanto a sua contribuição para o sistema judicial concernente à decisão do julgador.

Esses quatro anos de estudos permitiram-me enfrentar o desafio de aprender a trilhar o caminho de pesquisadora, diferenciando-me da atuação profissional no contexto da Justiça no qual estava imersa. Estudar 10 meses em Coimbra favoreceu a imprescindível imersão no conhecimento na área em que atuo e, também, em uma cultura com diferenças por sua origem 
céltica, mas também, semelhanças, pelas origens históricas que envolvem a nossa colonização. Essa oportunidade mostrou que tratar a criança como sujeito de direitos ainda é uma luta a ser conquistada, ultrapassa os limites nacionais e inclui outros países, cujos pesquisadores também manifestam estarem preocupados com essa temática. Assim sendo, acredita-se que, para a implantação de políticas públicas que abranjam o cumprimento pela via da prática no atendimento ao princípio do melhor interesse da criança, a presente tese é parte integrante dessa conjuntura que ecoa com os pesquisadores que atuam nessa perspectiva e, também, com os profissionais que se dedicam a trabalhar com esse assunto.

Mediante todo o exposto, enfatiza-se que a investigação desenvolvida confirma a tese de que a criança consegue comunicar e expressar o seu sofrimento em processos que lhe dizem respeito quando é oferecido espaço seguro e acolhedor, demonstrando sua capacidade de transitar entre a autonomia e a dependência que tem dos adultos que são seus responsáveis. Com isso, a criança permite que os atores privilegiem suas demandas e realizem tomadas de decisão favoráveis ao seu melhor interesse, levando em conta o contexto familiar conflituoso nos processos que envolvem a disputa de sua guarda. 


\section{REFERÊNCIAS}

Abela, A., \& Walker, J. (2014). Global changes in marriage, parenting and family life: An overview. In A. Abela \& J. Walker (Eds.). Contemporary issues in family studies: Global perspectives on partnerships, parenting and support in a changing world. (pp. 5-15). Chichester/UK: Wiley Blackwell.

Ackerman, M. J. (2006). Clinician's guide to child custody evaluations. ( ${ }^{\text {rd }}$ ed.). New Jersey: John Wiley \& Sons.

Agulhas, R., \& Anciães, A. (2014). Casos práticos em Psicologia Forense: Enquadramento legal e avalição pericial. Lisboa, Portugal: Edições Sílabo.

Ahrons, C. R. (1995). O bom divórcio: Como manter a família unida quando o casamento termina. Rio de Janeiro: Objetiva.

Ahrons, C. R. (2007). Family ties after divorce: Long-term implications for children. Family Process, 46(1), 53-65. Recuperado de http://onlinelibrary.wiley.com/doi/10.1111/j.15455300.2006.00191.x/pdf

Altoé, S. (2003). Atualidade da Psicologia Jurídica. In Bastos, R. L. (Org.). Psicologia, microrrupturas e subjetividades. (pp. 111-124). Rio de Janeiro: E-papers.

Amato, P. R. (2014). The consequences of divorce for adults and children: An update. Dru Istra Zagreb God, 23(1), 5-24. doi:10.5559/di.23.1.01

American Psychological Association (2010). Guidelines for Child Custody Evaluations in Family Law Proceedings. Recuperado de http://www.apa.org/practice/guidelines/childcustody.pdf

Andolfi, M. (1991). Terapia familiar: Un enfoque interaccional. Barcelona, Espanha: Paidós. Andolfi, M. (2013). A criança como recurso terapêutico: Os seminários de Maurizio Andolfi. (Trad. F. G. Ferreira). Portugal: Caminho. 
Arantes, E. M. M. (2009). Proteção integral à criança e ao adolescente: Proteção versus autonomia? Psicologia Clínica, 21(2), pp. 431-450. http://dx.doi.org/10.1590/S010356652009000200012

Ashbourne, L. M., Whitehead, D. L., \& Hawkins, L. (2013). Orienting services to separated/divorced fathers: A conceptual framework. Family Court Review, 51(4), 666680. doi:10.1111/fcre.12059

Ausloos, G. (1996). A competência das famílias: Tempo, caos e processo. (Trad. J. Coelho). Lisboa, Portugal: Climepsi.

Ayad, H., Moalla, Y., Ben Ahmed. S., Walha, A., Laaribi, H., \& Ghribi, F. (2002). Divorce parental et troubles psychopathologiques chez l'enfant et l'adolescent: étude comparative tunisienne. Neuropsychiatr Enfance, 50, 121-7. Recuperado de http://dx.doi.org/10.1016/S0222-9617(02)00079-X

Baker, A. J. L., \& Brassard, M. R. (2013). Adolescents caught in parental loyalty conflicts. Journal of Divorce \& Remarriage, 54(5), 393-413. doi:10.1080/10502556.2013.800398

Barbosa, L. de P. G., \& Castro, B. C. R. de (2013). Alienação parental: Um retrato dos processos e das famílias em situação de litígio. Brasília: Liber Livro.

Bauer, M. W., Gaskell, G. \& Allum, N. C. (2010). Qualidade, quantidade e interesses do conhecimento: Evitando confusões. (pp. 17-36). In M. W. Bauer \& G. Gaskell (Eds.), Pesquisa qualitativa com texto, imagem e som: Um manual prático (8 ${ }^{\mathrm{a}}$ ed., P. A. Guareschi, Trad.). Petrópolis: Vozes. (Trabalho original publicado em 2000).

Bell, F., Cashmore, J. Parkinson, P., \& Single, J. (2013). Outcomes of child-inclusive mediation. International Journal of Law, Policy and the Family, 27(1), 116-142. doi: 10.1093/lawfam/ebs017 
Birbaum, R., \& Bala, N. (2010).Toward the differentiation of high-conflict families: An analysis of social science research and Canadian case law. Family Court Review, 48(3), 403-416. doi: 10.1111/j.1744-1617.2010.01319.x

Birnbaum, R., Bala, N., \& Cyr, F. (2011). Children's experiences with family justice professionals in Ontario and Ohio. International Journal of Law, Policy and the Family 25(3), pp. 398-422. http://dx.doi:10.1093/lawfam/ebr014

Birnbaum, R., \& Saini, M. (2012). A qualitative synthesis of children's participation in custody disputes. Research on Social Work Practice, 22(4), pp. 400-409. http://dx.doi:10.1177/1049731512442985

Bojuwoye, O., \& Akpan, O. (2009). Personal, familial and environmental perspectives in children's reactions to parental divorce in South Africa. Journal of Family Studies, 15, $260-273$. Recuperado de http://jfs.econtentmanagement.com/archives/vol/15/issue/3/article/3128/personal-familial-andenvironmental-perspectives

Bomfim, E. de M. (1994). Psicologia Social, Psicologia do Esporte e Psicologia Jurídica. In Conselho Federal de Psicologia (Câmara de Educação e Formação Profissional). Psicólogo brasileiro: Práticas emergentes e desafios para a formação (2a ed.). São Paulo: Casa do Psicólogo.

Boszormenyi-Nagy, I., \& Spark G. M. (2008). Lealtades invisibles: Reciprocidad en terapia familiar intergeneracional. (I. Pardal, Trad.) Buenos Aires, Argentina: Amorrortu. (Trabalho original publicado em 1973).

Bowen, M. (1979). De la familia al individuo: La diferenciación del sí mismo en el sistema familiar. Barcelona, Espanha: Paidos.

Brito, L. M. T. de (2005a). Reflexões em torno da Psicologia Jurídica. In Cruz, R. M.; Maciel, S. K. \& Ramirez, D. C. (Eds.). O trabalho do psicólogo no campo jurídico. (pp. 9-17). São 
Paulo: Casa do Psicólogo.

Brito, L. M. T. (2005b). Guarda compartilhada: Um passaporte para a convivência familiar. In Associação de Pais e Mães Separados (Ed.), Guarda compartilhada: Aspectos psicológicos e jurídicos (pp. 53-71). Porto Alegre, RS: Equilíbrio.

Brito, L., Ayres, L., \& Amendola, M. (2006). A escuta de crianças no sistema de Justiça. Psicologia \& Sociedade, 18(3), 68-73. Recuperado de http://dx.doi.org/10.1590/S010271822006000300010

Brito, L. M. T. (2008). Alianças desfeitas, ninhos refeitos: Mudanças na família pós divórcio. In L. M. T. Brito (Ed.), Famílias e separações: Perspectivas da Psicologia Jurídica. (pp. 17-48) Rio de Janeiro, RJ: EdUERJ.

Britto, N. (2002). Rivalidade fraterna: O ódio e o ciúme entre irmãos. São Paulo, SP: Ágora. Byrnes, P. (2011). Voices of children in the legal process. Journal of Family Studies. 17(1), pp. 44-58. Recuperado de http://jfs.e-contentmanagement.com/archives/

Calil, V. L. L. (1987). Terapia Familiar e de Casal. $2^{a}$ ed. São Paulo: Summus.

Cano, D. S., Gabarra, L. M., Moré, C. O., \& Crepaldi, M. A. (2009). As transições familiares do divórcio ao recasamento no contexto brasileiro. Psicologia: Reflexão e Crítica, 22(2), 214-222. http://dx.doi.org/10.1590/S0102-79722009000200007

Cardoso, V., \& Costa, L. F. (2014). "Não me perguntem com quem eu quero ficar": A voz da criança e os avós no pedido de guarda judicial. Revista de Psicologia da IMED, 6(1) pp. $58-64$. Recuperado de http://seer.imed.edu.br/index.php/revistapsico/article/viewFile/316/408

Carraro, M. P. de Q., \& Penso, M. A. (2012). Juízes de batina: Reflexões sobre a relação entre a magistratura e o divino na formação do arquétipo de juiz. In M. A. Penso, \& T. M. C. de Almeida (Eds.). Direitos e conflitos psicossociais: Ações e interfaces disciplinares (pp. 3-17). São Paulo, SP: Roca. 
Cashmore, J. (2011). Children's participation in family law decision-making: Theoretical approaches to understanding children's views. Children and Youth Services Review, 33, pp. 515-520. Recuperado de http://ssrn.com/abstract=1685703

Cashmore, J., \& Parkinson, P. (2008). Children's and parents' perceptions on children's participation in decision making after parental separation and divorce. Family Court Review, 46(1) pp. 91-104. http://dx.doi:10.1046/j.1365-2702.2001.00433.x

Cashmore, J., \& Parkinson, P. (2009). Children's participation in family law disputes: The views of children, parents, lawyers and counsellors. Family Matters, 82, pp. 15-21. Recuperado de http://ssrn.com/abstract=1471693

Cashmore, J., \& Parkinson, P. (2011). Reasons for disputes in high conflict families. Journal of Family $\quad$ Studies. 17(3), 186-203. Recuperado de http://go.galegroup.com.ez54.periodicos.capes.gov.br/ps/i.do?id=GALE\%7CA29161537 $3 \& v=2.1 \& u=$ capes $\& i t=r \& p=A O N E \& s w=w \& a s i d=d 926 \mathrm{da} 4 \mathrm{e} 431102 \mathrm{be} 95 \mathrm{a} 9178 \mathrm{e} 7 \mathrm{ffbffc} 6$

Catarino, A. C. L. (2013). O papel mediador do coping na relação entre o ambiente familiar e a satisfação com a vida nos adolescentes. (Dissertação de Mestrado. Universidade de Lisboa, Portugal). Recuperado de http://hdl.handle.net/10451/9853

Cerveny, C. M. de O. (2006). Família e filhos no divórcio. In C. M. de O. Cerveny (Ed.), Família e... (pp. 83-95). São Paulo, SP: Casa do Psicólogo.

Cohen, O., \& Levita, Z. (2011). High-conflict divorced couples: Combining systemic and psychodynamic perspectives. Journal of Family Therapy, 34, 387-402. doi: 10.1111/j.1467-6427.2011.00539.x

Conselho Federal de Psicologia (2003). Manual de referências. Recuperado de http://site.cfp.org.br/wp-content/uploads/2003/06/resolucao2003_7.pdf 
Conselho Federal de Psicologia (2010). Referências técnicas para atuação do psicólogo em Varas de Família. Recuperado de http://crepop.pol.org.br/novo/wpcontent/uploads/2011/01/ReferenciaAtua\%C3\%A7\%C3\%A3oVarasFamilia.pdf

Costa, A. P. M., \& Miragem, F. B. (2012). A escuta e a participação de crianças e adolescentes em tomadas de decisão e o princípio do melhor interesse. In M. M. M. Costa, M. C. H. Leal, R. G. Leal, \& J. R. dos Reis (Eds.). As políticas públicas no constitucionalismo contemporâneo (pp. 682-692) (tomo 4). Santa Cruz do Sul/RS: EDUNISC. Recuperado de http://redenep.unisc.br/portal/upload/com_editora_livro/1364238825.pdf\#page=22

Costa, L. F., Penso, M. A., Legnani, V. N., \& Sudbrack, M. F. O. (2009). As competências da Psicologia Jurídica na avaliação psicossocial de famílias em conflito. Psicologia \& Sociedade, 21(2), pp. 233-241. Recuperado de http://dx.doi.org/10.1590/S010271822009000200010

Costa, V. A., \& Sani, A. I. (2007). Sintomatologia de pós-stress traumático em crianças expostas a violência interparental: Do conflito ao ajustamento. Revista da Faculdade de Ciências $\quad d a \quad$ Saúde, $\quad 4, \quad 282-290 . \quad$ Recuperado de https://bdigital.ufp.pt/dspace/handle/10284/455

Creswell, J. W. (2010). Projeto de pesquisa: métodos qualitativo, quantitativo e misto. ( $3^{\mathrm{a}}$ ed., M. F. Lopes, Trad.). Porto Alegre: Artmed. (Trabalho original publicado em 2009).

Elrod, L. (2010). National and international momentum builds for more child focus in relocation disputes. Family Law Quarterly, 44(3), 341. Recuperado de http://go.galegroup.com.ez54.periodicos.capes.gov.br/ps/i.do?id=GALE\%7CA24809397 $5 \& v=2.1 \& u=$ capes $\& \mathrm{it}=\mathrm{r} \& \mathrm{p}=\mathrm{AONE} \& \mathrm{sw}=\mathrm{w} \& \mathrm{asid}=6 \mathrm{~d} 39617 \mathrm{f} 287 \mathrm{ea} 157 \mathrm{~b} 3 \mathrm{bc} 15 \mathrm{f} 7 \mathrm{e} 9196 \mathrm{ab} 1$ Emery, R. E. (2012). Renegotiating family relationships: Divorce, child custody and mediation. ( $2^{\text {nd }}$ ed.). New York/London: Guilford Press. 
Emery, R. E., Otto, R. K. \& O’Donohue, W. T. (2005). A critical assessment of child custody evaluations: Limited science and a flawed system. American Psychological Society, 6 (1), pp. 1-29. doi: 10.1111/j.1529-1006.2005.00020.x

Emery, Rowen, \& Dinescu (2014). New roles for family therapists in the Courts: An overview with a focus on custody dispute resolution. Family Process 53(3), 500-515. doi: 10.1111/famp.12077

Esteves de Vasconcellos, M. J. E. (2006). Parte III: Epistemologia Sistêmica: Pensamento Sistêmico-Novo Paradigmático. In J. G. Aun, M. J. Esteves de Vasconcellos, \& S. V. Coelho (Eds.), Atendimento sistêmico de famílias e redes sociais: Fundamentos teóricos e epistemológicos (Vol I. $2^{\mathrm{a}}$ ed.) Belo Horizonte: Ophicina de Arte \& Prosa.

Farinha R. M. E., \& Afonso, C. S. (2009). "Gravidez na adolescência: Crise, resposta familiar e bem-estar emocional”. (Dissertação de Mestrado. Universidade de Lisboa, Portugal). Recuperado de http://hdl.handle.net/10451/849

Féres-Carneiro, T. (2003). Separação: Doloroso processo de dissolução da conjugalidade. Estudos de Psicologia, 8(3), 367-374. http://dx.doi.org/10.1590/S1413294X2003000300003

Ferreira, M. T. F. (2008). A manifestação da vontade da criança na disputa judicial de guarda: Uma escuta psicanalítica. (Dissertação de Mestrado, Universidade Federal do Rio Grande do Norte, Natal, Brasil). Recuperado de http://www.dominiopublico.gov.br/pesquisa/DetalheObraForm.do?select_action=\&co_ob $\mathrm{ra}=127803$

Flick, U. (2009). Introdução à pesquisa qualitativa. ( $3^{a}$ ed., J. E. Costa, Trad.) Porto Alegre: Artmed. (Trabalho original publicado em 1995).

Foot, W. (2011). How children's voices were heard 'above the din' in family court proceedings in cases where there were allegations of child sexual abuse: The importance 
of judicial orientation and professional evidence in the discernment of the child's voice. Child Indicator Research 4(4), pp. 707-723. http://dx.doi10.1007/s12187-011-9123-5

Fourez, B. (2000). Fratria: Perspectivas históricas e societais. In E. Tilmans-Ostyn, \& M. Meynckens-Fourez (Eds.), Os recursos da fratria (pp. 3-17). Belo Horizonte, MG: ArteSã. (Trabalho original publicado em 1999).

França, F. (2004). Reflexões sobre a Psicologia Jurídica e seu panorama no Brasil. Psicologia: Teoria e Prática, 6(1), 73-80. Recuperado de editorarevistas.mackenzie.br/index.php/ptp/article/download/1200/896

Fuhrmann, G. S. W., \& Zibbell, R. A. (2012). Evaluation for child custody. New York: Oxford.

Gaskell, G. (2010). Entrevistas individuais e grupais. (pp. 64-89). In M. W. Bauer \& G. Gaskell (Eds.), Pesquisa qualitativa com texto, imagem e som: Um manual prático ( $8^{\mathrm{a}}$ ed., P. A. Guareschi, Trad.). Petrópolis: Vozes. (Trabalho original publicado em 2000).

Goldsmid, R., \& Féres-Carneiro, T. (2007). A função fraterna e as vicissitudes de ter e ser um irmão. Psicologia em Revista, 13(2), 293-308. Recuperado de http://pepsic.bvsalud.org/scielo.php?script=sci_arttext\&pid=S1677$11682007000200006 \& \operatorname{lng}=\mathrm{pt} \& \operatorname{lng}=\mathrm{pt}$

Gonçalves, C. de J. M. (2012, Maio 28). Breves considerações sobre o princípio do melhor interesse da criança e do adolescente. Lex Magister. Recuperado de http://www.editoramagister.com

Gonçalves, R. A. (2010). Psicologia Forense em Portugal: Uma história de responsabilidades e desafios. Análise Psicológica, 28(1), 107-115. doi:10.14417/ap.256

Graham, A., \& Fitzgerald, R. (2010). Exploring the promises and possibilities for children's participation in Family Relationship Centres. Family Matters, 84, 53-60. Recuperado de http://www.aifs.gov.au/institute/pubs/fammats.html 
Granjeiro, I. \& Costa, L. F. (2008). O estudo psicossocial forense como subsídio para a decisão judicial na situação de abuso sexual. Psicologia: Teoria e Pesquisa, 24(2), 161169. Retirado de http://www.scielo.br/pdf/ptp/v24n2/04.pdf

Jacó-Vilela, A. M. (2002). Introdução: Os primórdios da Psicologia Jurídica. In Brito, L. M. T. de, (Org.). Temas de Psicologia Jurídica. 4ª ed. (pp. 11-18). Rio de Janeiro: Relume Dumará.

Grisso, T. (2003). Evaluating competencies: Forensic assessments and instruments. ( $2^{\text {nd }}$ ed.). New York: Plenum Publishers.

Guanga, M. C. S. (2010). Factores que influyen en el divorcio y cómo éste afecta a los hijos. Tesina de licenciatura, Universidad de Cuenca, Ecuador. Recuperado de http://dspace.ucuenca.edu.ec/bitstream/123456789/2318/1/tps619.pdf

Hart, A. S. (2009). Child-inclusive mediation in cases of violence domestic in Australia. Conflict Resolution Quarterly, 27(1), 3-26. doi: 10.1002/crq.246

Holtzman, M. H. (2011). Family definitions and children's rights in custody decision making: The importance of a changing litigant context. Family Court Review, 49(3), 591-609. doi:10.1111/j.1744-1617.2011.01395.x

Huss, M. T. (2009). Forensic Psychology: Research, clinical practice, and applications. United Kingdom: Wiley-Blackwell.

IBGE (2010). Estatísticas do Registro Civil. Vol. 37. Retirado de http://www.ibge.gov.br/home/estatistica/populacao/registrocivil/2010/rc2010.pdf

James, A. (2006). Giving voice to children's voices: Practices and problems, pitfalls and potentials. American Anthropologist, 109(2), pp. 261-272.

Johnston, J. R.; Roseby, V., \& Kuehnle, K. (2009). In the name of the child: A developmental approach to understanding and helping children of conflicted and violent divorce. $\left(2^{\text {nd }}\right.$ ed.). New York: Springer Publishing Company. 
Juras, M. M. \& Costa, L. F. (2011a). O divórcio destrutivo na perspectiva de filhos com menos de 12 anos. Estilos da Clínica, 2011, 16(1), 222-245. Recuperado de http://pepsic.bvsalud.org/scielo.php?script=sci_arttext\&pid=S1415$71282011000100013 \& \operatorname{lng}=\mathrm{pt} \& \operatorname{lng}=\mathrm{pt}$

Juras, M. M., \& Costa, L. F. (2011b). Divórcio destrutivo e Justiça. Revista de Direito Privado, 12(45), 265-297.

Kelly, J. B. (2012). Risk and protective factors associated with child and adolescent adjustment following separation and divorce: Social science applications. In K. F. Kuehnle, \& L. M. Drozd (Eds), Parenting plan evaluations: Applied research for the Family Court (pp. 49-84). New York: Oxford University Press.

Kiesling, C. (2011). An attachment theory approach to narrating the faith journey of children of parental divorce. International Journal of Children's Spirituality, 16(4), 301-13. Recuperado de http://www.tandfonline.com/doi/pdf/10.1080/1364436X.2011.639746

Kohm, L. (2008). Tracing the foundations of the best interests of the child standard in American jurisprudence. Journal of Law and Family Studies, 10(2). Recuperado de http://epubs.utah.edu/index.php/jlfs/article/view/46/39

Kreuz, S. L., (2012). Direito à convivência familiar da criança e do adolescente: Direitos fundamentais, princípios constitucionais e alternativas ao acolhimento institucional. Porto Alegre: Juruá.

Lago, V. M. (2008). As práticas em avaliação psicológica nos casos de disputa de guarda de filhos Brasil. (Dissertação de Mestrado, Universidade Federal do Rio Grande do Sul, Porto Alegre, Brasil). Recuperado de http://hdl.handle.net/10183/12595

Lago, V. de M., Amaral, C. E. dos S., Bosa, C. A., \& Bandeira, D. R. (2010). Instrumentos que avaliam a relação entre pais e filhos. Revista Brasileira de Crescimento $e$ 
Desenvolvimento Humano, 20(2), pp. 330-341. Recuperado de http://pepsic.bvsalud.org/pdf/rbcdh/v20n2/15.pdf

Lago, V. de M., Amato, P., Teixeira, P. A., Rovinski, S. L. R., \& Bandeira, D. R. (2009). Um breve histórico da psicologia jurídica no Brasil e seus campos de atuação. Estudos de Psicologia, 26(4), pp. 483-491. http://dx.doi.org/10.1590/S0103-166X2009000400009

Lago, V. de M., \& Bandeira, D. R. (2008). As práticas em avaliação psicológica nos casos de disputa de guarda de filhos Brasil. Avaliação Psicológica, 7(2), pp. 223-234. Recuperado de http://pepsic.bvsalud.org/scielo.php?script=sci_arttext\&pid=S1677$04712008000200013 \& \operatorname{lng}=\mathrm{pt} \& \operatorname{tng}=\mathrm{pt}$

Lago, V. de M., \& Bandeira, D. R. (2009). A Psicologia e as demandas atuais do Direito de Família. Psicologia Ciência e Profissão, 29(2), pp. 290-305. http://dx.doi.org/10.1590/S1414-98932009000200007

Lago, V. de M., Amaral, C. E. dos S., Bosa, C. A., \& Bandeira, D. R. (2010). Instrumentos que avaliam a relação entre pais e filhos. Revista Brasileira de Crescimento $e$ Desenvolvimento Humano, 20(2), pp. 330-341. Recuperado de http://pepsic.bvsalud.org/scielo.php?script=sci_arttext\&pid=S0104$12822010000200015 \& \operatorname{lng}=\mathrm{pt} \& \operatorname{tng}=\mathrm{pt}$

Lago, V. de M., \& Bandeira, D. R. (2013). Sistema de avaliação do relacionamento parental. São Paulo: Pearson.

Lamela, D., Castro, M., \& Figueiredo, B. (2010). Pais por inteiro: avaliação preliminar da eficácia de uma intervenção em grupo para pais divorciados. Psicologia: Reflexão $e$ Crítica, 23(2), 334-344. doi.org/10.1590/S0102-79722010000200016

Landsford, J. E. (2009). Parental divorce and children's adjustment. Perspectives on Psychological Science, 4(2) 140-152. doi: 10.1111/j.1745-6924.2009.01114.x 
Lee, N. (2010). As vozes das crianças, tomada de decisão e mudança. In F. Muller (Ed.), Infância em perspectiva: Políticas, pesquisas e instituições (pp. 42-64). São Paulo: Cortez Editora.

Lehrmann, D. H. (2010). Advancing children's rights to be heard and protected: The model representation of children in abuse, neglect, and custody proceedings act. Behavior Science Law, 28, 463-479. doi: 10.1002/bsl

Lei n. 8.069, de 13 de julho de 1990 (1990). Dispõe sobre o Estatuto da Criança e do Adolescente. Diário Oficial da União. Brasília, DF. Recuperado de http://www.planalto.gov.br/ccivil_03/leis/18069.htm.

Lei n. 10.406, de 10 de janeiro de 2002 (2002). Institui o Código Civil. Diário Oficial da União. Brasília, $\quad$ DF. Recuperado de http://www.planalto.gov.br/ccivil_03/leis/2002/L10406.htm

Lima, H. G. D. de (2003). Apresentação. In H. G. D. de Lima (Ed.), Construindo caminhos para a intervenção psicossocial no contexto da Justiça (pp. 15-18). Recuperado de http://www.tjdft.jus.br/publicacoes/edicoes-especiais/livros/constCaminhos.pdf

Lisboa, C., Koller, S. H., Ribas, F. F., Bitencourt, K., Oliveira, L., Porciuncula, L. P., De Marchi, R. B. (2002). Estratégias de coping de crianças vítimas e não vítimas de violência doméstica. Psicologia: Reflexão e Crítica, 15(2), 345-362. http://dx.doi.org/10.1590/S0102-79722002000200012

Lucas, N., Nicholson, J. M., \& Erbas, B. (2013). Child mental health after parental separation: The impact of resident/non-resident parenting, parent mental health, conflict and socioeconomics. Journal of Family Studies, 19(1) 53-69. doi: 10.5172/jfs.2013.19.1.53

MacMillan, H. L., Wathen, C. N., \& Varcoe, C. M. (2013). Intimate partner violence in the family: Considerations for children's safety. Child Abuse \& Neglect, 37, 1186-1191. doi.org/10.1016/j.chiabu.2013.05.005 
Maes, S. DJ., Mol, J. D., \& Buysse, A. (2011). Children's experiences and meaning construction on parental divorce: A focus group study. Childhood, 19(2), 266-279. Recuperado de http://chd.sagepub.com/content/19/2/266.full.pdf+html

Manita, C. \& Machado, C. (2012). A Psicologia Forense em Portugal: Novos rumos na consolidação da relação com o sistema de Justiça. Análise Psicológica. 30 (1-2), 15-32, Recuperado de http://www.scielo.mec.pt/scielo.php?script=sci_arttext\&pid=S0870$\underline{82312012000100004 \& \operatorname{lng}=p t \& t \operatorname{lng}=p t}$

Mayall, (2010). Relações geracionais na família. In F. Muller (Ed.). Infância em perspectiva: Políticas, pesquisas e instituições (pp. 165-186). São Paulo: Cortez.

McIntosh, J. E., Wells, Y. D., Smyth, B. M., \& Long, C. M. (2008). Child-focused and childinclusive divorce mediation: Comparative outcomes from a prospective study of post separation adjustment. Family Court Review, 46(1), 105-124. doi: 10.1111/j.17441617.2007.00186.x

McNamee, C. B., Amato, P., \& V. King, (2014). Nonresident father involvement with children and divorced women's likelihood of remarriage. Journal of Marriage and Family,76, 862-874. doi:10.1111/jomf.12118

Meynckens-Fourez, M. (2000). A fratria, o ponto de vista eco-sistêmico. In E. Tilmans-Ostyn, \& M. Meynckens-Fourez (Eds.), Os recursos da fratria (pp. 19-53). Belo Horizonte, MG: ArteSã. (Trabalho original publicado em 1999).

Minayo, M. C. de S. (2014). O desafio do conhecimento: Pesquisa qualitativa em saúde. (14 ${ }^{\mathrm{a}}$ ed.). São Paulo: Hucitec/Rio de Janeiro: Abrasco.

Minuchin, S. (1985). Calidoscopio familiar. Imágenes de violencia y curación. Buenos Aires, Argentina: Paidos. (Trabalho original publicado em 1984).

Minuchin, S. (1990). Famílias, funcionamento e tratamento. (Trad. J. A. Cunha). Porto Alegre, RS: Artes Médicas. (Trabalho original publicado em 1980). 
Minuchin, S., \& Fishman, H. C. (1990). Técnicas de Terapia Familiar. (C. Kinsch \& M. E. F. R. Maia, Trads.) Belo Horizonte, MG: Artes Médicas.

Minuchin, S., Lee, W-Y, \& Simon, G. M. (2008). Dominando a terapia familiar. (2ª . ed., G. Klein, Trad.). Porto Alegre, RS: Artmed.

Minuchin, S., Nichols, M. P., \& Lee, W.-Y. (2009). Famílias e casais: Do sintoma ao sistema. (J. D. Mello, Trad.). Porto Alegre, RS: Artes Médicas.

Miranda Junior, H. C. de (1998). Psicologia e Justiça: A Psicologia e as práticas judiciárias na construção do ideal de Justiça. Psicologia: Ciência e Profissão. http://dx.doi.org/10.1590/S1414-98931998000100004

Miranda Junior, H. C. de (2010). Um psicólogo no Tribunal de Família: A prática na interface Direito e Psicanálise. Belo Horizonte: ArteSã.

Monteiro, A. R. (2010). Direitos da criança: Era uma vez... Coimbra, Portugal: Almedina.

Muniz, A. A. M., \& Féres-Carneiro, T. (2012). Função fraterna: Reflexões a partir do filme Príncipe das Marés. Psicologia em Revista, 18(1), 41-56. http://dx.doi.org/10.5752/P.1678-9563.2012v18n1p41

Nunes-Costa, R. A.; Lamela, D. J. P. V., \& Figueiredo, B. F. C. (2009). Adaptação psicossocial e saúde física em crianças de pais separados. Jornal de Pediatria, 85(5), pp. 385-396. doi:10.2223/JPED.1925

Orgilés, M., \& Samper, M. D. (2011). El impacto del divorcio en la calidad de vida de los niños de 8 a 12 años de edad en la provincia de Alicante. Gac Sanit, 25(6), 490-494. Recuperado de http://scielo.isciii.es/scielo.php?pid=S0213$91112011000600009 \&$ script=sci_arttext

Owen, J. \& Roads, G. K. (2012). Reducing interparental conflict among parents in contentious child custody disputes: An initial investigation of the working together 
program. Journal of Marital and Family Therapy 38(3), 542-555. doi: 10.1111/j.17520606.2010.00215.x

Patel, S. H., \& Choate, L. H. (2014). Conducting child custody evaluations: Best practices for mental health, counselors, who are court-appointed as child custody evaluators. Journal of Mental Health Counseling, 36(1), 18-30. Recuperado de https://www.questia.com/library/journal/1G1-355938646/conducting-child-custodyevaluations-best-practices

Pereira, A. \& Matos, M. (2008). As crianças, o divórcio e a regulamentação litigiosa do poder paternal. In Violência e vítimas de crimes: Crianças. Machado, C \& Gonçalves, R. A. (Eds.) (2008) (3 ${ }^{\text {a }}$ ed.), Vol. 2. (pp. 275-299). Coimbra, Portugal: Quarteto.

Pereira, A. L., \& Matos, M. (2011). Avaliação psicológica das responsabilidades parentais nos casos de separação e divórcio. In M. Matos, R. A. Gonçalves, \& C. Machado (Eds.), Manual de psicologia forense: Contextos práticos e desafios (pp. 311-347). Braga, Portugal: Psiquilíbrios.

Pessina, L. M., \& Mendes, M. da C. (2012). Entrelaçando conhecimentos e práticas: O casamento entre o Serviço Social e a Psicologia no SERAF/SEPSI. In V. Brito (Org.), Conexões: Teoria e prática do trabalho em redes na Secretaria Psicossocial Judiciária do TJDFT (pp. 65-85). Rio de Janeiro: Lumen Juris.

Pinto, H. A., \& Pereira, M. da G. (2005). Separação e divórcio: Um olhar feminino. Coimbra, Portugal: Quarteto.

Portugal, A. P., \& Alberto, I. (2014). Escala de avaliação da comunicação na parentlidade (COMPA): Desenvolvimento e validação de uma medida da comunicação parento-filial. Avances en Psicología Latinoamericana, 32(1), 85-103. doi:dx.doi.org/10.12804/apl32.1.2014.06 
Punch, S. (2010). Experiências fraternais das crianças e ordem de nascimento: "Alguém acima e alguém abaixo de mim”. In F. Muller (Ed.). Infância em perspectiva: Políticas, pesquisas e instituições (pp. 187-222). São Paulo: Cortez.

Puviani, V. (2011). O uso do desenho no trabalho clínico com crianças: Teoria e técnica. (S. Garavello, Trad.). Belo Horizonte: ArteSã.

Raposo, H. S., Figueiredo, B. F. de C., Lamela, D. J. P. do V., Nunes-Costa, R. A., Castro, M. C., \& Prego, J. (2011). Ajustamento da criança à separação ou divórcio dos pais. Revista Psiquiatria Clínica, 38(1), 29-33. doi.org/10.1590/S0101-60832011000100007

Ribeiro, R. (2010). A criança e o adolescente nos estudos psicossociais de Varas de Família. In I. Ghesti-Galvão, \& E. C. B. Roque (Orgs.), Aplicação da lei em uma perspectiva interprofissional: Direito, Psicologia, Psiquiatria, Serviço Social e Ciências Sociais na prática jurisdicional (pp. 271-282). Rio de Janeiro: Lumen Juris.

Rodrigues, L., Gonçalves, M. E. \& Teixeira, G. E. (2011). Indicadores de vulnerabilidade e risco social para as famílias pobres cadastradas no Ministério de Desenvolvimento Social, no município de Montes Claros (MG). Recuperado de http://www.bnb.gov.br/content/aplicacao/eventos/forumbnb2011/docs/2011_indicadores_ vulnerabilidade.pdf

Rodrigues, D. de M. \& Lima, H. G. D. de. (2006). Intervenções sistêmicas em um contexto de decisão. In H. G. D. de Lima (Org.), Construindo caminhos para intervenção psicossocial no contexto da Justiça (pp. 21-44). Brasília: TJDFT.

Sani, A. I. (2008). Crianças expostas à violência interparental. In C. Machado, \& R. A. Gonçalves (Eds.), Violência e vítimas de crimes: Crianças (pp. 95-127). (3 ${ }^{\mathrm{a}}$ ed.). (Vol. 2). Coimbra, Portugal: Quarteto. 
Santa Rosa, B., Almeida, F., \& Corte-Real, F. (2014). A perícia médico-legal e o respeito pela autonomia da criança. In M. Paulino \& F. Almeida (Eds.), Psicologia, Justiça e ciências forenses: Perspectivas atuais (pp. 161-178). Lisboa, Portugal: Pactor.

Santa Rosa, B., Corte-Real, F., \& Vieira. D. N. (2013). O respeito pela autonomia da criança na regulação das responsabilidades parentais. Acta Medica Portuguesa, 26(6), pp. 637643.

Recuperado

de http://www.actamedicaportuguesa.com/revista/index.php/amp/article/view/4050

Santos, J. C., \& Hamú, E. M. F. e S. (2010). A criança triangulada entre a mãe e a avó. In I. Ghesti-Galvão \& E. C. B. Roque (eds.), Aplicação da lei em uma perspectiva interprofissional: direito, psicologia, psiquiatria, serviço social e ciências sociais na prática jurisdicional (pp. 341-351). Rio de Janeiro, RJ: Lumen Juris.

Santos, M. R. R. dos, (2014). O sofrimento da criança na vivência da disputa de guarda no contexto da Justiça. Revista Portuguesa de Pedagogia, 48(1), 25-37. http://dx.doi.org/10.14195/1647-8614_48-1_2

Santos, M. R. R. dos, \& Costa, L. F. (2010). Campo psicossocial e jurídico: Relações de poder nas decisões de conflito familiares. Estudos de Psicologia, 27(4), pp. 553-561. http://dx.doi.org/10.1590/S0103-166X2010000400013

Santos, Q. N. (2013). Estratégia de enfrentamento (coping) da família ante um membro familiar hospitalizado: Uma revisão de literatura brasileira. Mudanças - Psicologia da Saúde. 21(2), 40-47. http://dx.doi.org/10.15603/2176-1019/mud.v21n2p40-47

Satir, V. (1993). Terapia do grupo familiar. (A. Nolli, Trad.). Rio de Janeiro: Francisco Alves.

Saywitz, K., Camparo, L. B., \& Romanoff, A. (2010). Interviewing children in custody cases: Implications of research and policy for practice. Behavioral Sciences and the Law, 28, 542-562. http://dx.doi:10.1002/bsl.945 
Shaw, J., Öhman, L., \& van Koppen, P. (2013). Psychology and law: The past, present, and future of the discipline. Psychology, Crime \& Law. doi.org/10.1080/1068316X.2013.793979

Shelton, K. H., \& Harold, G. T. (2007). Marital conflict and children's adjustment: The mediating and moderating role of children's coping strategies. Social Development, 16(3), 497-512. doi: 10.1111/j.1467-9507.2007.00400.x

Shienvold, A. T. (2011). The high-conflict divorce \& your children's adjustment. Family Advocate, 34(1), 32. Recuperado de http://go.galegroup.com

Shumaker, D. M., Miller, C., \& Ortiz, C. The forgotten bonds: The assessment and contemplation of sibling attachment in divorce and parental separation. Family Court Review, 49(1), 46-58. doi: 10.1111/j.1744-1617.2010.01352.x

Silva, D. M. P. da, (2007). Psicologia Jurídica, uma ciência em expansão. (pp. 6-7) Psiquê. Ed. Especial. 1(5).

Silveira, M. L. C. S. (2009). Da rivalidade ao amor: Irmãos para sempre. Investigação, 9(1), $33-44$. Recuperado de http://publicacoes.unifran.br/index.php/investigacao/article/view/36/8

Silveira, D. T. \& Córdova, F. P. (2009). A pesquisa qualitativa. In T. E Gerhardt \& D. T. Silveira (Eds.). Métodos de pesquisa. (pp. 31-42). Porto Alegre: Editora da UFRGS.

Simeón, M. (2000). Em que se transformam as fratrias depois das separações e recomposições? In E. Tilmans-Ostyn, \& M. Meynckens-Fourez (Eds.), Os recursos da fratria (pp. 135-162). Belo Horizonte, MG: ArteSã. (Trabalho original publicado em 1999).

Skjørten, K. (2013). Children's voices in Norwegian custody cases. International Journal of Law, Policy and the Family 27(3), pp. 289-309. http://dx.doi:10.1093/lawfam/ebt011 
Soares, L. I. M. da S. (2013). Trajetórias de crianças pautadas pela violência interparental. (Dissertação de Mestrado, Universidade Fernando Pessoa, Porto, Portugal). Recuperado de http://hdl.handle.net/10284/4034

Stahl, P. M. (2011). Conducting child custody evaluations: From basic to complex issues. California, United States: Sage Publications.

Stover, C. S. (2013).Commentary: Factors predicting family court decisions in high-conflict divorce. The Journal of the American Academy of Psychiatry and the Law, 41(2), 219223. Recuperado de http://www.jaapl.org

Symons, D. K. (2010). A review of the practice and science of child custody and access assessment in the United States and Canada. Professional Psychology: Research and Practice, 41(3), pp. 267-273. http://dx.doi.org/10.1037/a0019271

Trindade, J. (2007). Manual de Psicologia Jurídica: Para operadores do Direito. $2^{\mathrm{a}}$ ed. Porto Alegre: Livraria do Advogado.

UNHCR (2008). Guidelines on determining the best interests of the child. Recuperado dehttp://www.unhcr.org/4566b16b2.pdf

UNICEF (1990). Convenção sobre os Direitos da Criança. Recuperado de http://www.unicef.pt/docs/pdf_publicacoes/convencao_direitos_crianca2004.pdf

van Nijnatten, C., \& Jongen, E. (2011). Professional conversations with children in divorcerelated child welfare inquiries. Childhood, 18(4), pp. 540-555. doi: $10.1177 / 0907568211398157$

Vasconcelos, E. M. (2004). Complexidade e pesquisa interdisciplinar: Epistemologia e metodologia operativa. $2^{\mathrm{a}}$ ed. Petrópolis: Ed. Vozes.

Vélez, C. E., Wolchik, S. A., Tein, J.-Y., \& Sandler, I. (2011). Protecting children from the consequences of divorce: a longitudinal study of the effects of parenting on children's 
coping processes. Child Development, 82(1), 244-257. Recuperado de http://onlinelibrary.wiley.com/doi/10.1111/j.1467-8624.2010.01553.x/pdf

Wallerstein, J., Lewis, J., \& Blakeslee, S. (2002). Filhos do divórcio (W. Fuchs, trad.) São Paulo, SP: Loyola. (Trabalho original publicado em 2000).

Walsh, F. (2003). Family resilience: A framework for clinical practice. Family Process, 42(1), 1-18. Recuperado de http://www.celf.ucla.edu/2010_conference_articles/Walsh_2003.pdf Walsh, F. (2010). Spiritual diversity: Multifaith perspectives in Family Therapy. Family Process, 49(3), 330-348. Recuperado de http://www.ncbi.nlm.nih.gov/pubmed/20831764 Watzlawick, P., Beavin, J. H., \& Jackson, D. D., (2002). Pragmática da comunicação humana: Um estudo dos padrões, patologias e paradoxos da interação. (Trad. A. Cabral). São Paulo, SP: Cultrix. (Trabalho original publicado em 1967). 
APÊNDICES 
Apêndice 1. Termo de Consentimento Livre e Esclarecido

A criança está sendo convidado(a) a participar da pesquisa " $O$ sofrimento da criança a respeito do litígio familiar no contexto da avaliação psicossocial na Justiça" de responsabilidade da pesquisadora Marcia Regina Ribeiro dos Santos, aluna de doutorado da Universidade de Brasília. O objetivo desta pesquisa é conhecer o sofrimento da criança sobre o litígio familiar no contexto da avaliação psicossocial na Justiça. Assim, gostaria de consultá-lo(a) sobre seu interesse e disponibilidade de cooperar com a pesquisa como responsável pela criança em questão.

Você receberá todos os esclarecimentos necessários antes, durante e após a finalização da pesquisa, e lhe asseguro que o seu nome não será divulgado, sendo mantido o mais rigoroso sigilo mediante a omissão total de informações que permitam identificá-lo(a), bem como a criança participante. Os dados provenientes de sua participação na pesquisa e da criança em questão, tais como questionários, entrevistas, fitas de gravação ou filmagem, ficarão sob a guarda do pesquisador responsável pela pesquisa.

A coleta de dados será realizada por meio de entrevista que inclui a utilização de fotos e desenhos. É para estes procedimentos que você está sendo convidado a participar. Sua participação na pesquisa, bem como da criança não implica em nenhum risco.

Espera-se que esta pesquisa possa contribuir para melhorar as relações entre a criança e seus familiares.

Sua participação, bem como da criança, é voluntária e livre de qualquer remuneração ou benefício. Você é livre para recusar-se a participar, bem como a permitir a participação da criança, retirar seu consentimento ou interromper sua participação e da criança a qualquer momento. A recusa em participar não irá acarretar qualquer penalidade ou perda de benefícios, nem mesmo alterar a decisão judicial.

Se você tiver qualquer dúvida em relação à pesquisa, você pode me contatar através do telefone 6131031942 ou pelo e-mail marcia.ribeiro@tjdft.jus.br.

A equipe de pesquisa garante que os resultados do estudo serão devolvidos aos participantes por meio de carta, podendo ser publicados posteriormente na comunidade científica.

Este projeto foi revisado e aprovado pelo Comitê de Ética em Pesquisa do Instituto de Ciências Humanas da Universidade de Brasília - CEP/IH. As informações com relação à assinatura do TCLE ou os direitos do sujeito da pesquisa podem ser obtidos através do e-mail do CEP/IH cep_ih@unb.br.

Este documento foi elaborado em duas vias, uma ficará com o(a) pesquisador(a) responsável pela pesquisa e a outra com o senhor(a).

Assinatura do(a) participante
Assinatura do(a) pesquisador(a)

Brasília/DF, de de 
Apêndice 2. Termo de Assentimento

Tendo em vista que a pesquisa " $O$ sofrimento da criança a respeito do litígio familiar no contexto da avaliação psicossocial na Justiça” envolve sujeitos menores de dezoito anos, este termo de assentimento foi apresentado na forma oral, na linguagem da criança, para ela compreender a pesquisa e se manifestar livremente para aceitar ou não a participar da investigação proposta.

Brasília/DF, de de

Assinatura do(a) pesquisador(a) 
Apêndice 3. Identificação da Criança

Informações obtidas durante o acompanhamento da realização da avaliação. Essas informações ficam documentadas nas pastas de registro efetuado pelo profissional responsável pela realização do estudo psicossocial e, também, no parecer técnico:

Nome (será trocado por um fictício para fins de sigilo):

Data de Nascimento/idade:

Sexo:

Escolarização:

Estuda em escola pública ou privada?

Região administrativa onde reside (também trocado, porém que tenham características semelhantes):

Com quem reside:

Número de irmãos e de irmãos unilaterais e idade de cada um:

Situação socioeconômica. 
Apêndice 4. Roteiro de Entrevista

Criança com o pesquisador (durante a realização da entrevista com a pesquisadora sendo que o profissional do setor psicossocial poderá estar ou não presente):

\section{A) Geral}

Após a apresentação da pesquisadora, efetuar a solicitação de autorização da criança para sua participação na pesquisa.

Estabelecer rapport perguntando se ela sabe o motivo pelo qual ela está na Justiça.

Retomar a explicação do motivo de ela estar na Justiça e no setor psicossocial (que já foi efetuada pelo profissional responsável pelo estudo psicossocial).

O que ela expressa no decorrer da entrevista em relação ao sofrimento vivido no contexto familiar?

Que imagens aparecem nos desenhos da representação do sofrimento?

Durante a utilização dos desenhos, como ela se posiciona em relação ao sofrimento?

Que histórias, relacionadas ao sofrimento, ela conta a partir dos desenhos?

Buscar saber o que ela entende sobre o motivo que levou os pais à Justiça.

Buscar saber dela como ela está neste momento frente ao contexto por ela descrito que envolve conflito entre os pais.

B) Específico:

Entrevista semiestruturada de perguntas para a criança:

O que trouxe você e sua família à Justiça?

A quem cabe a decisão do processo?

O que é disputa?

O que é conflito/briga?

Como você se sente neste momento frente ao conflito/briga/disputa que observa entre seus familiares?

O que é sofrimento?

Você gosta de desenhar/Você poderia fazer um desenho?

Faça um desenho que represente o que traz sofrimento para você, o que preocupa e/ou traz tristeza para você que te envolve neste processo com sua família na Justiça (Problema)? 
Faça um desenho que represente a solução do que você desenhou como sofrimento, preocupação, tristeza (Solução).

No início da entrevista, como você estava se sentindo?

Como você está se sentindo, agora, ao final? 
Apêndice 5. Certificado

Parabenizo e agradeço (nome da criança) que participou, como importante colaboradora para o progresso da ciência, contribuindo com esta pesquisa no conhecimento e na compreensão do sofrimento das crianças que vivenciam o conflito e a disputa na Justiça após a separação de seus pais.

Brasília-DF, de de 2013.

Marcia Regina Ribeiro dos Santos

Pesquisadora 
ANEXOS 
Anexo 1. Carta de Aprovação do Comitê de Ética

Comitê de Ética em Pesquisa

Instituto de Ciências Humanas

Universidade de Brasilia
Instituto de Ciências Humanas
Campus Universitário Darcy Ribeiro

Universidade de Brasília Campus Universitário Darcy Ribeiro

\section{ANÁLISE DE PROJETO DE PESQUISA}

Título do Projeto: A PERSPECTIVA DA CRIANÇA SOBRE O TEMPO VIVIDO DURANTE O LITÍGIO FAMILIAR

Pesquisador(a) responsável: MARCIA REGINA SANTOS

Com base nas Resoluções 196/96, do CNS/MS, que regulamenta a ética da pesquisa em seres humanos, o Comitê de Ética em Pesquisa com Seres Humanos do Instituto de Ciências Humanas da Universidade de Brasília, após análise dos aspectos éticos, resolveu APROVAR o projeto intitulado "A PERSPECTIVA DA CRIANÇA SOBRE O TEMPO VIVIDO DURANTE O LITÍGIO FAMILIAR".

O pesquisador responsável fica notificado da obrigatoriedade da apresentação de um relatório final sucinto e objetivo sobre o desenvolvimento do Projeto, no prazo de 1 (um) ano a contar da presente data (itens VII.13 letra "d" e IX.2 letra "c" da Resolução CNS 196/96).

Brasília, 10 de setembro de 2012.

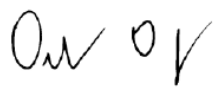

Debora Diniz

Coordenadora Geral - CEP/IH 
Anexo 2. Aceite Institucional

\section{ACEITE INSTITUCIONAL}

O(A) Sr./Sra. MARILIA LOBÃO RIBEIRO, SECRETÁRIA DA SECRETARIA PSICOSSOCIAL JUDICIÁRIA do(a) TRIBUNAL DE JUSTIÇA DO DISTRITO FEDERAL É DOSOS TERRITÓRIOS, está de acordo com a realização da pesquisa A PERSPECTIVA DA CRIANÇA SOBRE O TEMPO VIVIDO DURANTE O LITIGIO FAMILIAR, de responsabilidade do(a) pesquisador(a) MARCIA REGINA RIBEIRO DOS SANTOS aluno(a) de DOUTORADO no Departamento de PSICOLOGIA CLÍNICA DO INSTITUDO DE PSICOLOGIA da Universidade de Brasília, realizado sob orientação de LIANA FORTUNATO COSTA, após revisão e aprovação pelo Comitê de Ética em Pesquisa do Instituto de Ciências Humanas da Universidade de Brasília - CEP/IH.

0 estudo envolve a realização de ENTREVISTAS E DESENHOS com CRIANÇAS ENTRE 6 E 7 ANOS A 11 ANOS DE IDADE. A pesquisa terá a duração de TRÊS ANOS, com previsão de início em JULHO DE 2012 e término em JUNHO DE 2015.

Eu, MARILIA LOBÃO RIBEIRO do(a) SECRETARIA PSICOSSOCIAL JUDICIÁRIA dO TRIBUNAL DE JUSTIÇA DO DISTRITO FEDERAL, declaro conhecer e cumprir as Resoluções Éticas Brasileiras, em especial a Resolução CNS 196/96. Esta instituição está ciente de suas co-respońnsabilidades como instituição co-participante do presente projeto de pesquisa, e de seu compromisso no resguardo da segurança e bem-estar dos sujeitos de pesquisa nela recrutados, dispondo de infra-estrutura necessária para a garantia de tal segurança e bem-estar.,

Brasilia;2Ode aqusto de 2012.
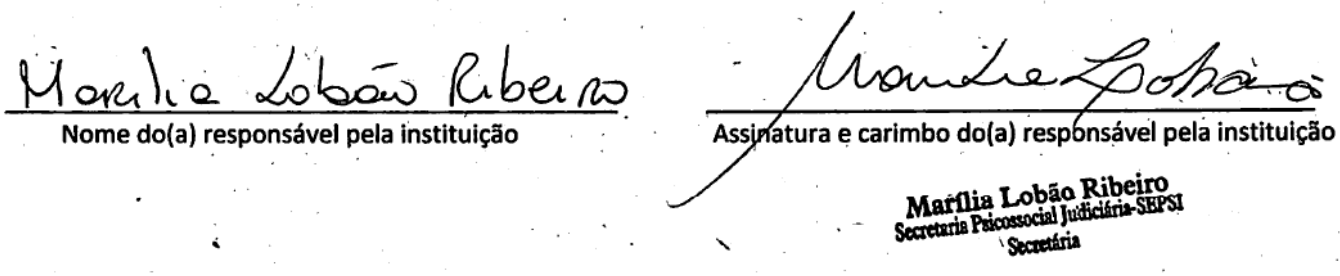

cep_lh_modelo_termo_de_aceite_institucional 
Anexo 3. Desenho Aninha

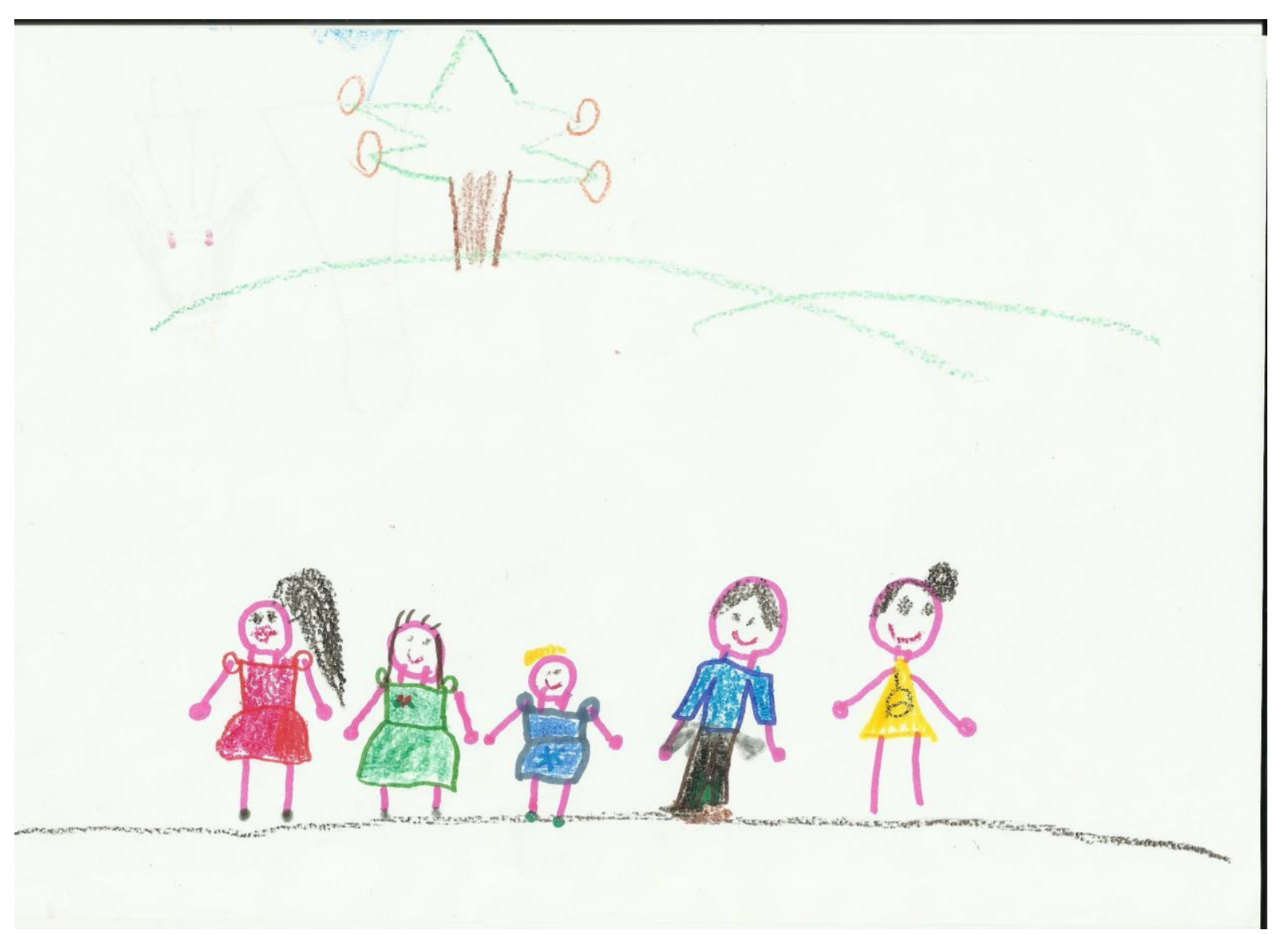


Anexo 4. Desenho Bibinha

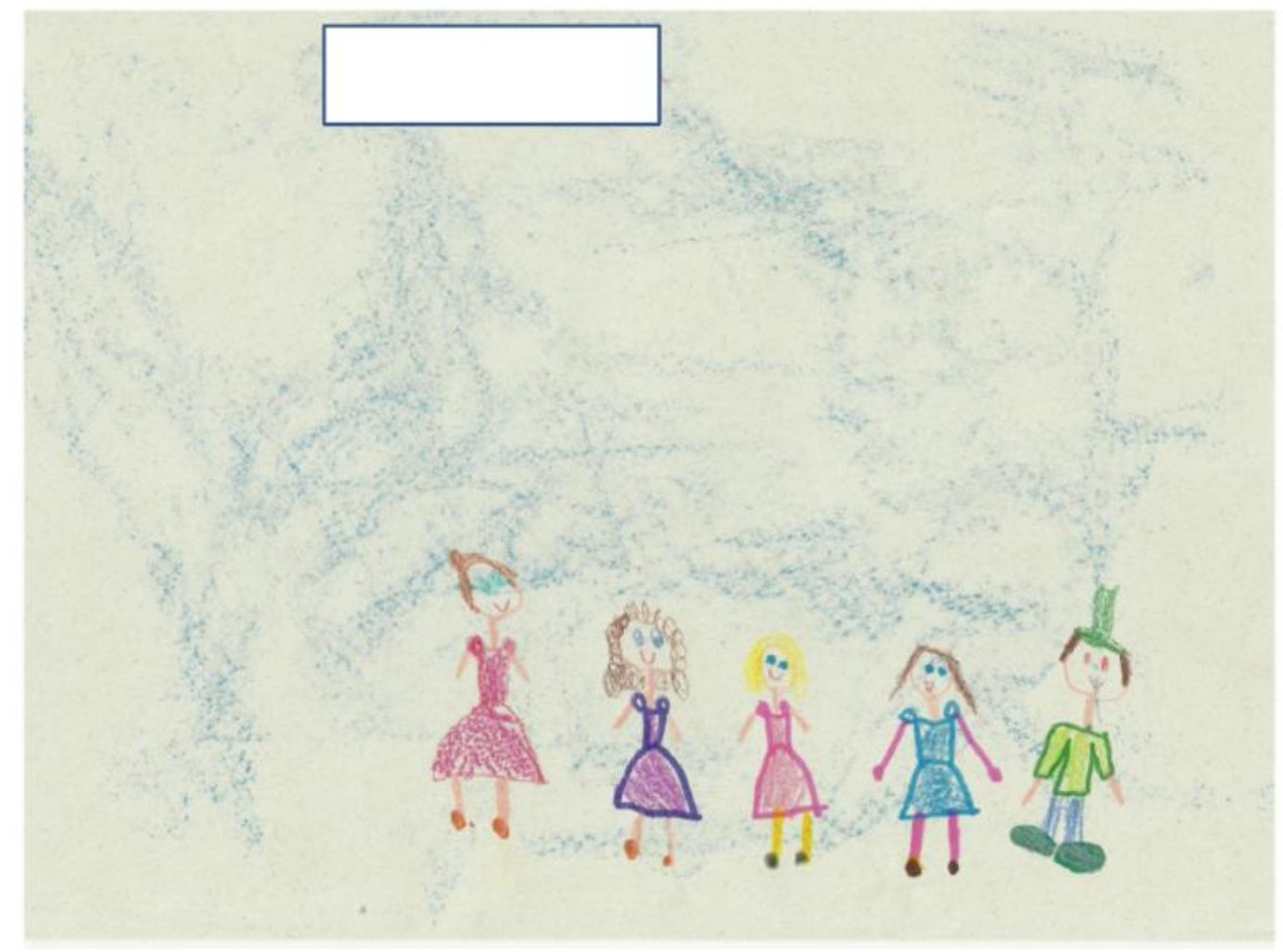


Anexo:5. Ceci

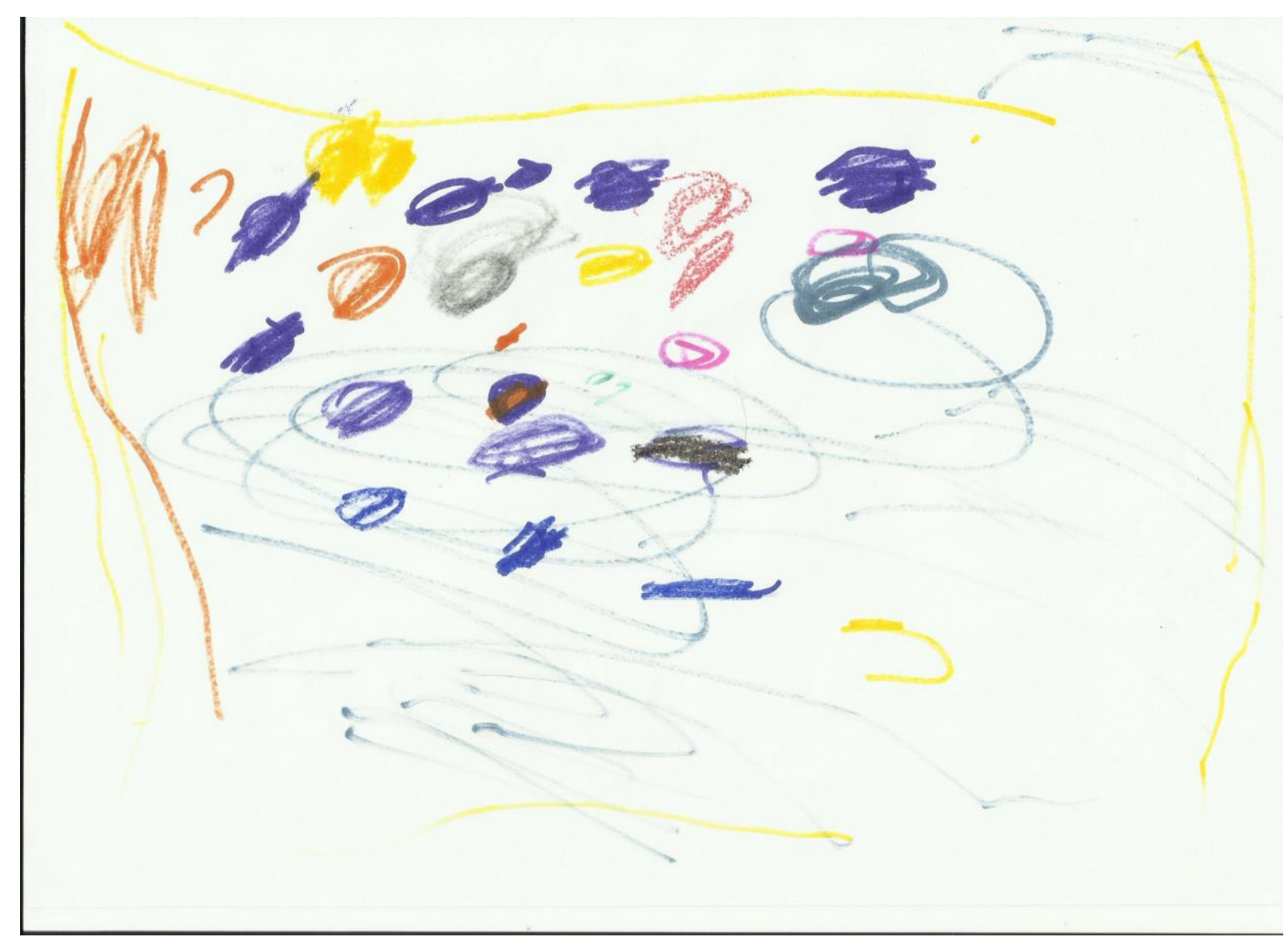


Anexo 6. Desenho Problema Absinto

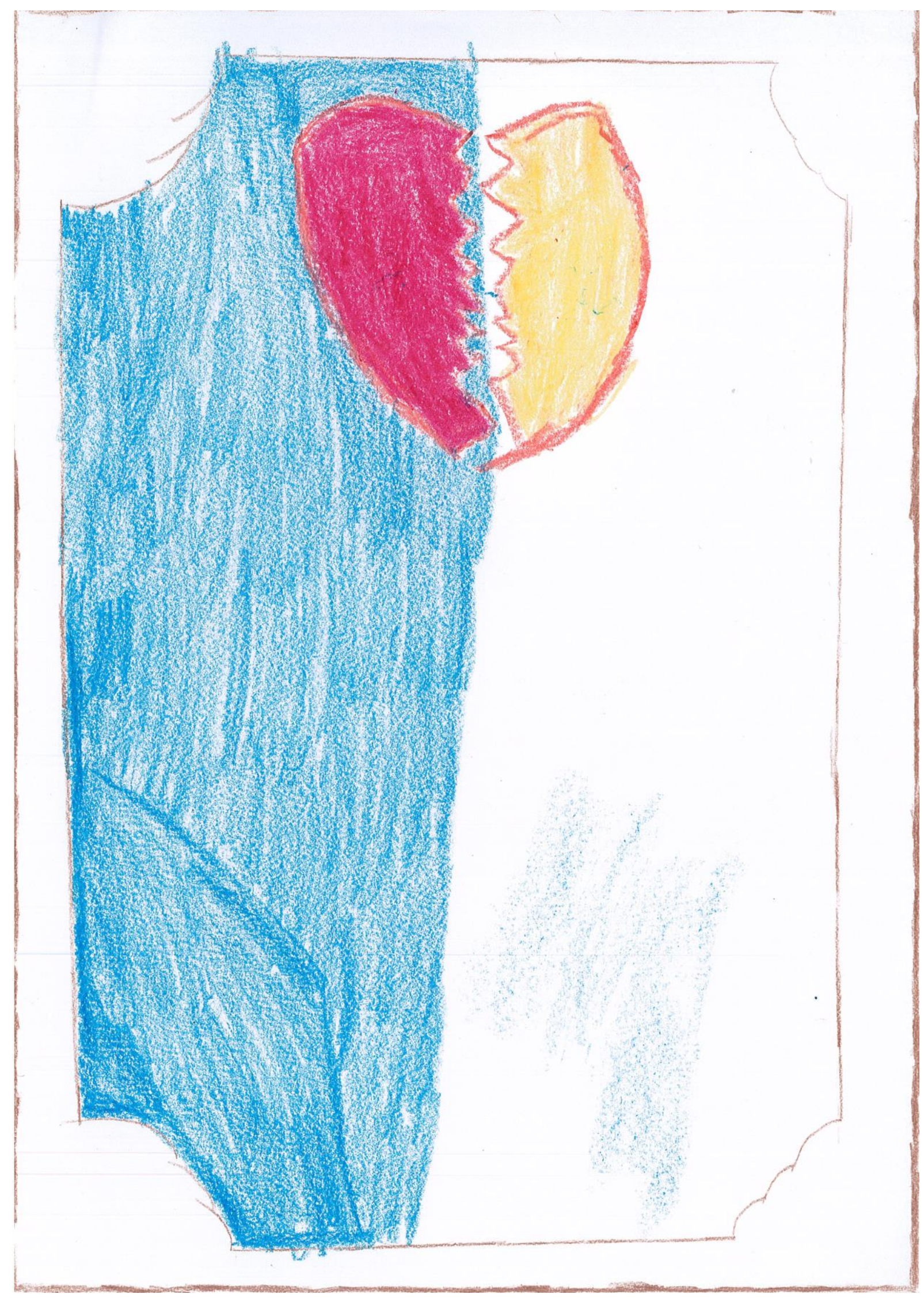


Anexo 7. Desenho Solução Absinto

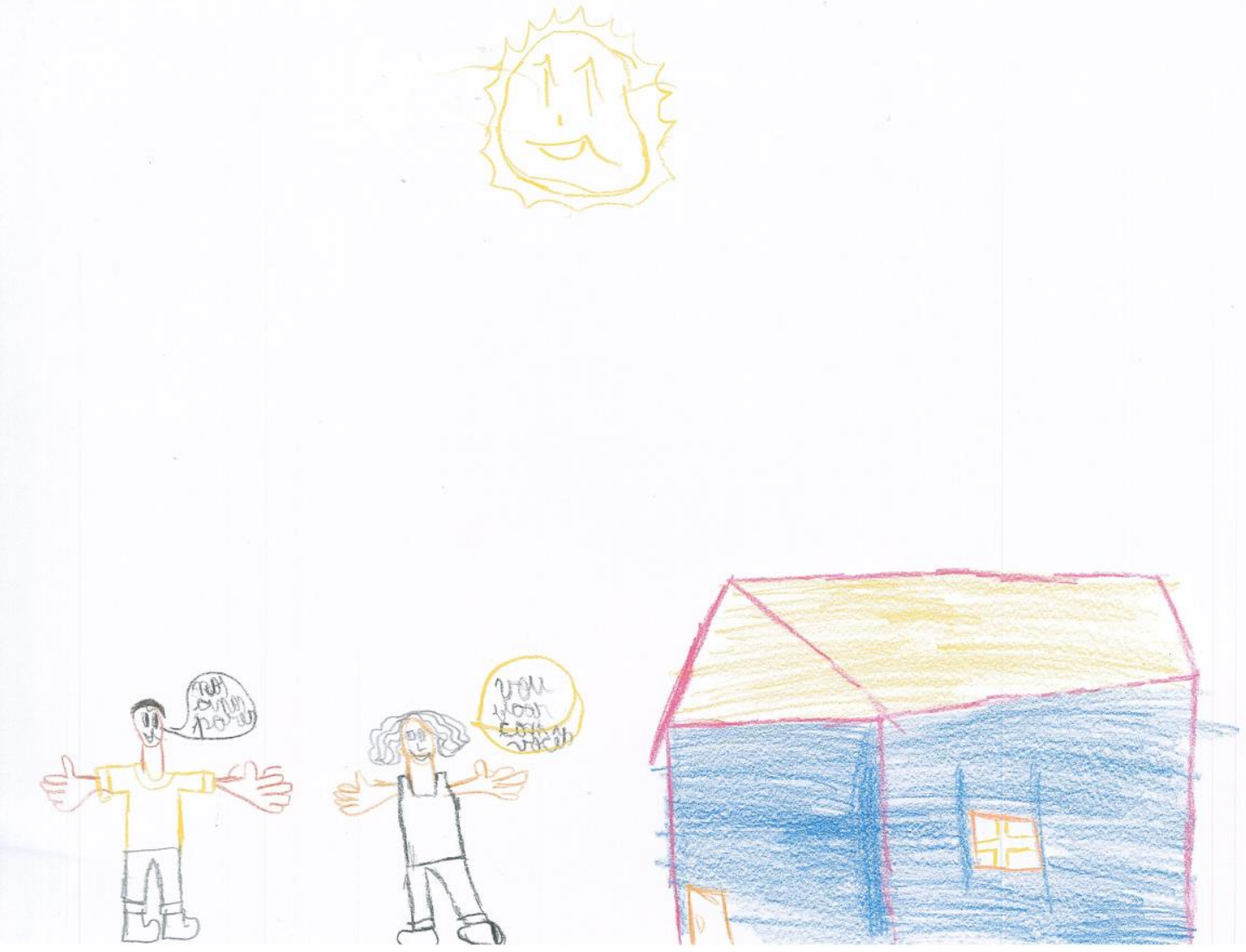


Anexo 8. Desenho Problema Calunga

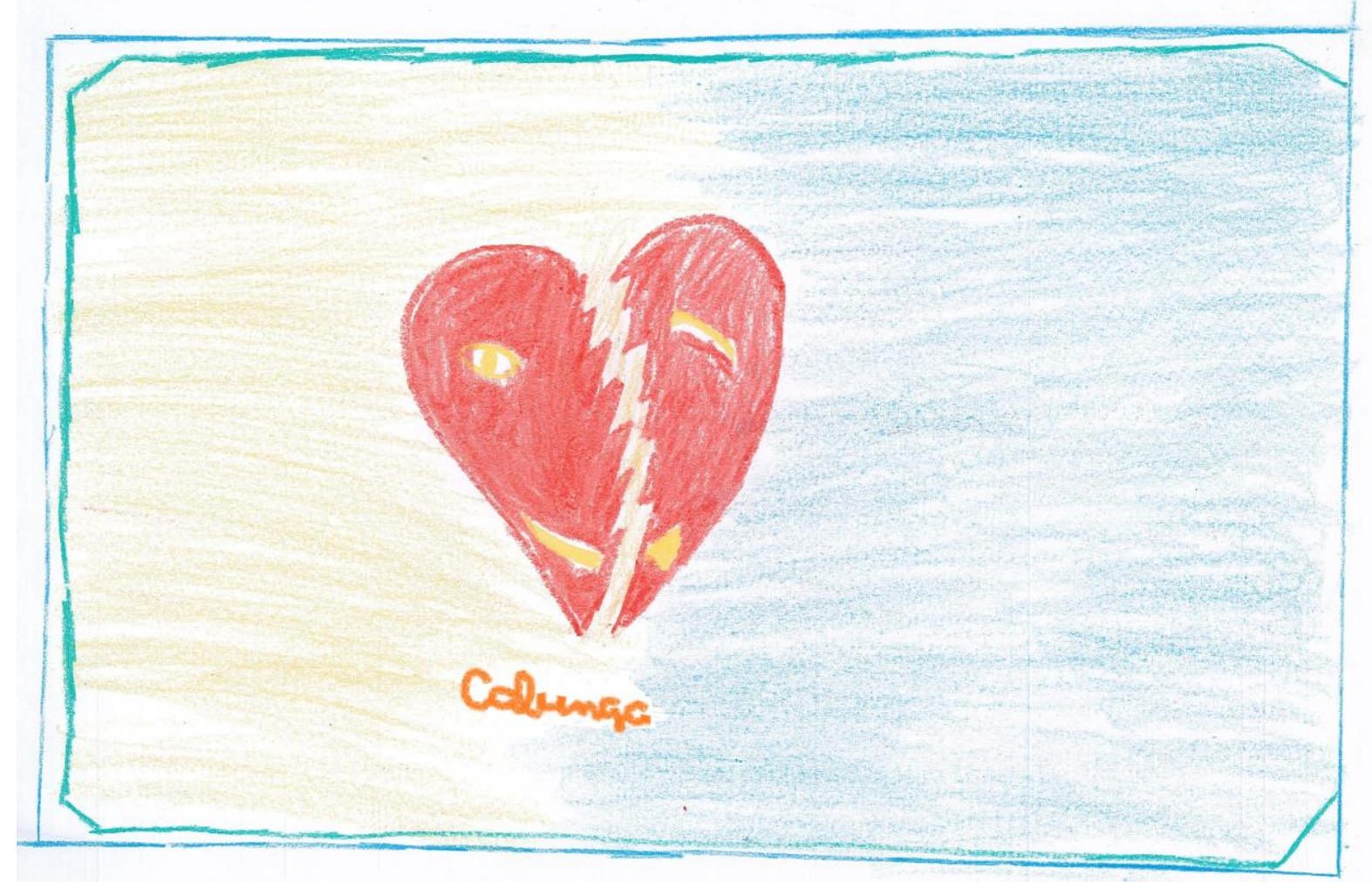


Anexo 9. Desenho Solução Calunga

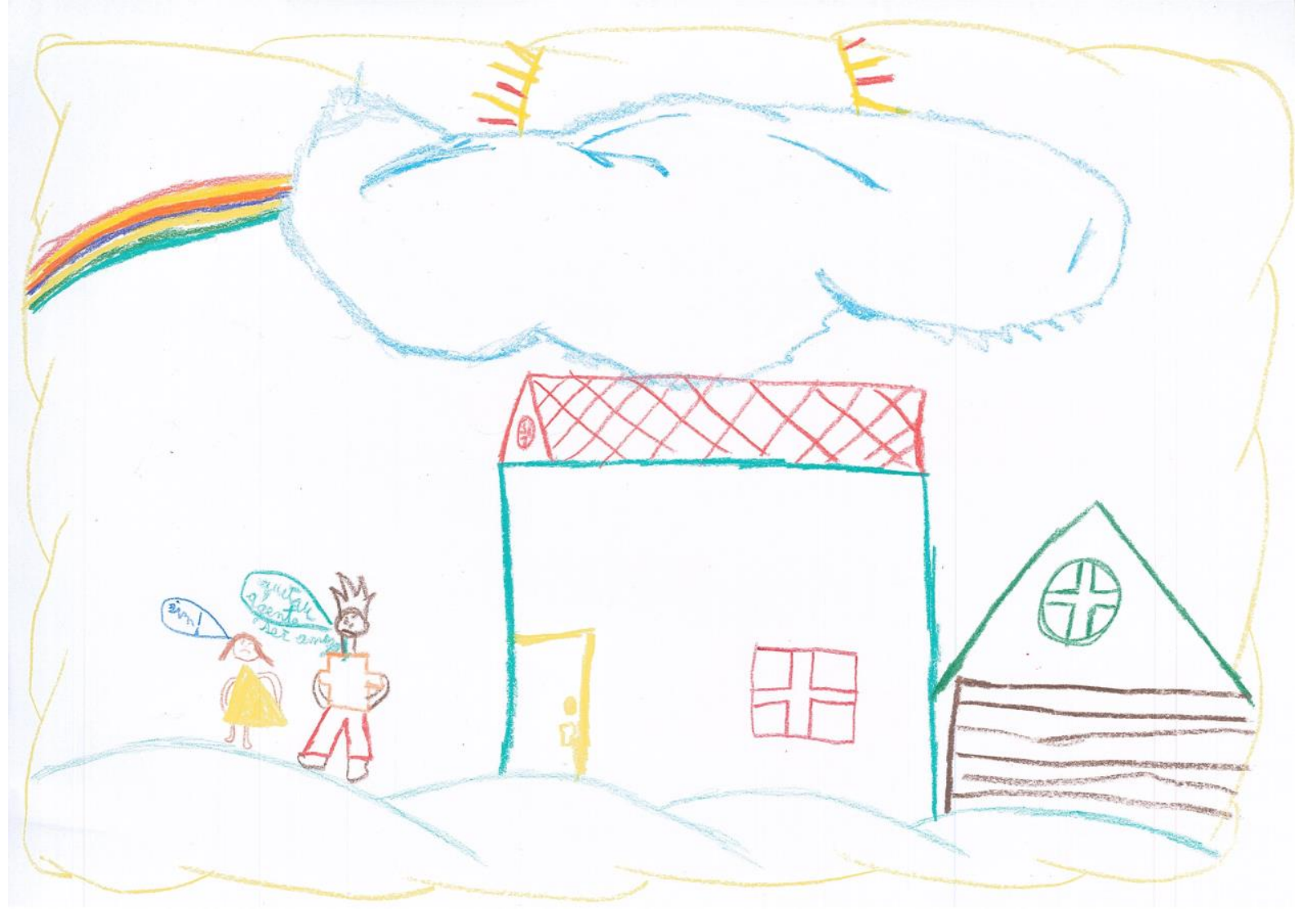


Anexo 10. Desenho Problema Ônix

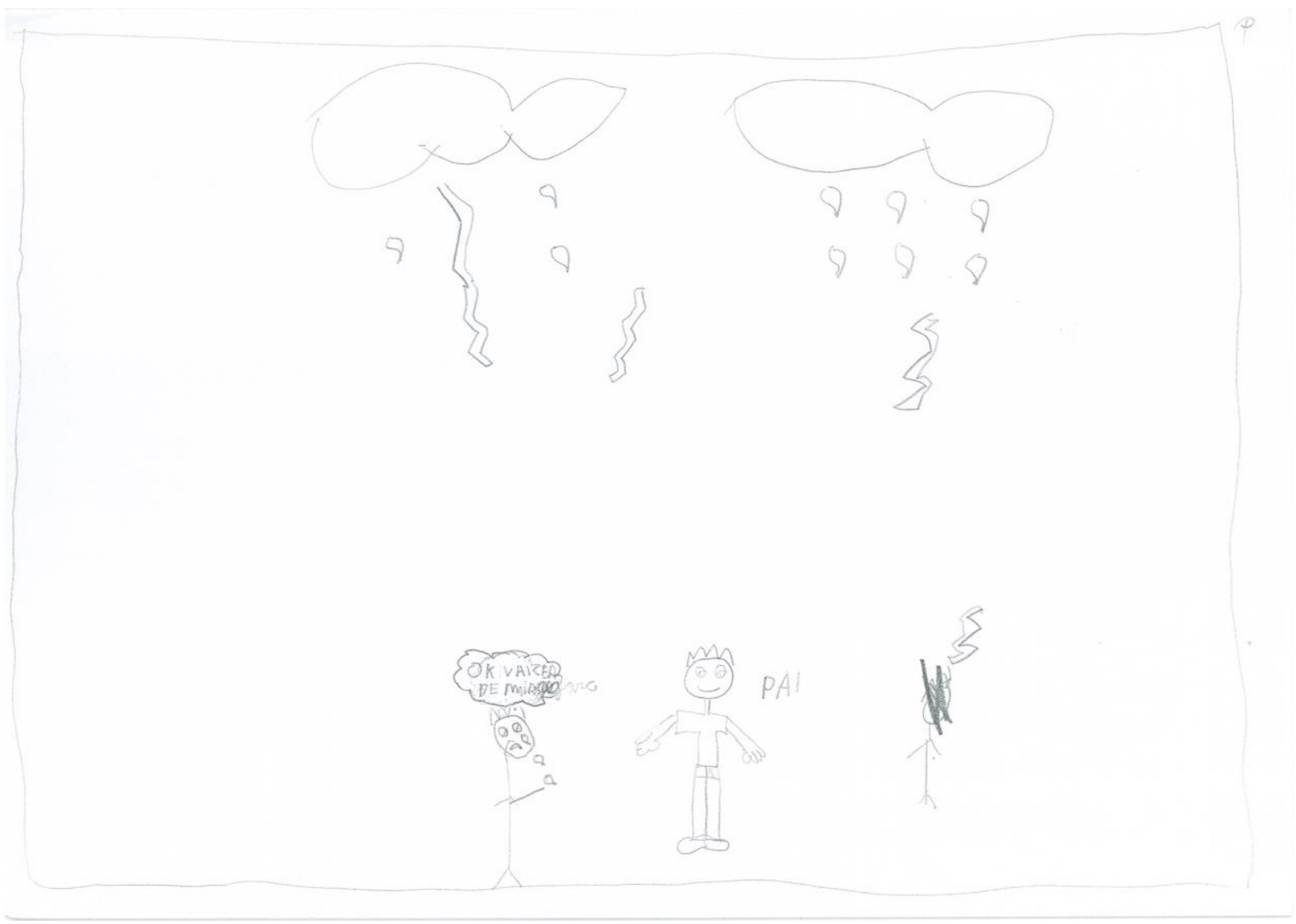


Anexo 11. Desenho Solução Ônix

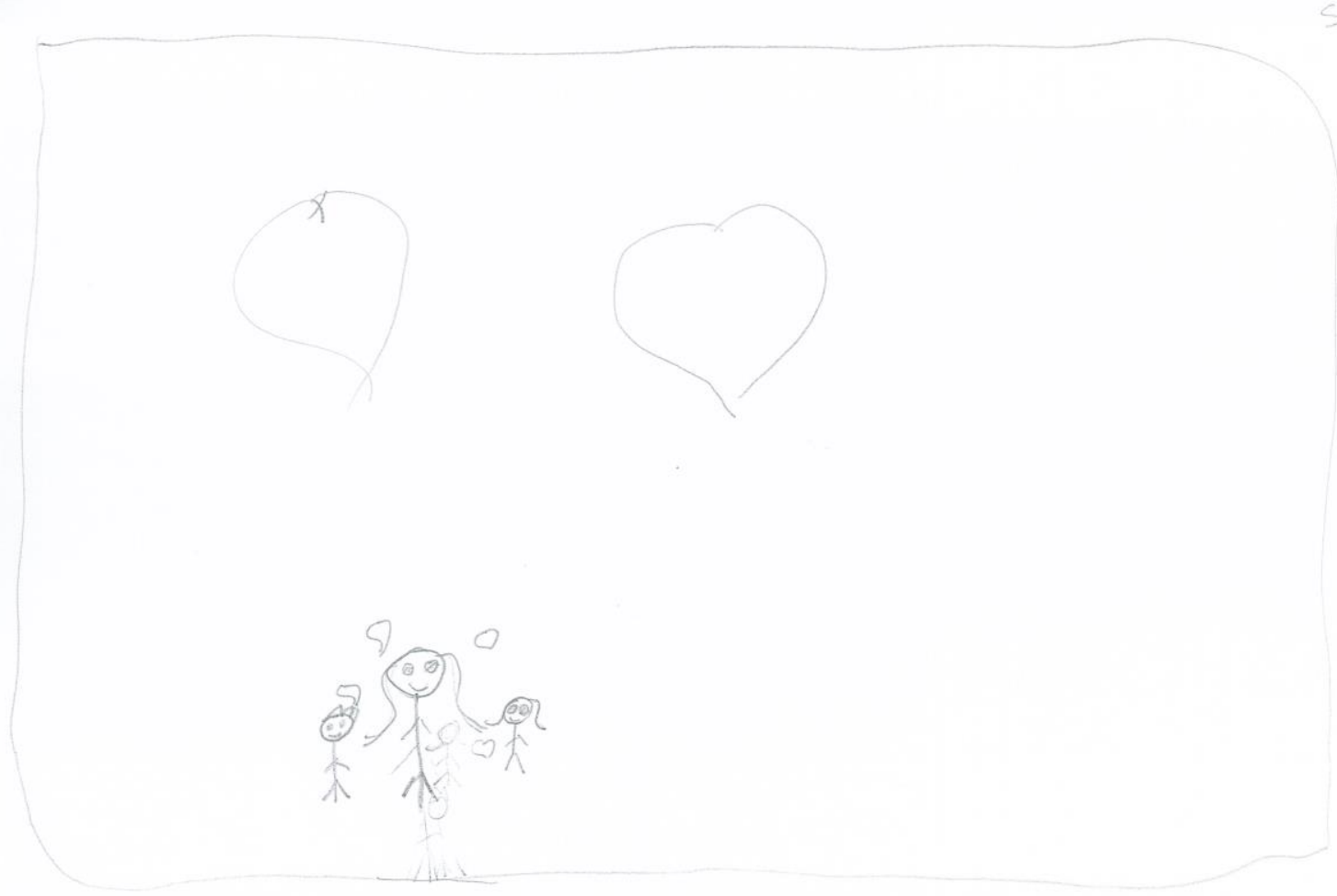


Anexo 12. Desenho Problema Jaspe

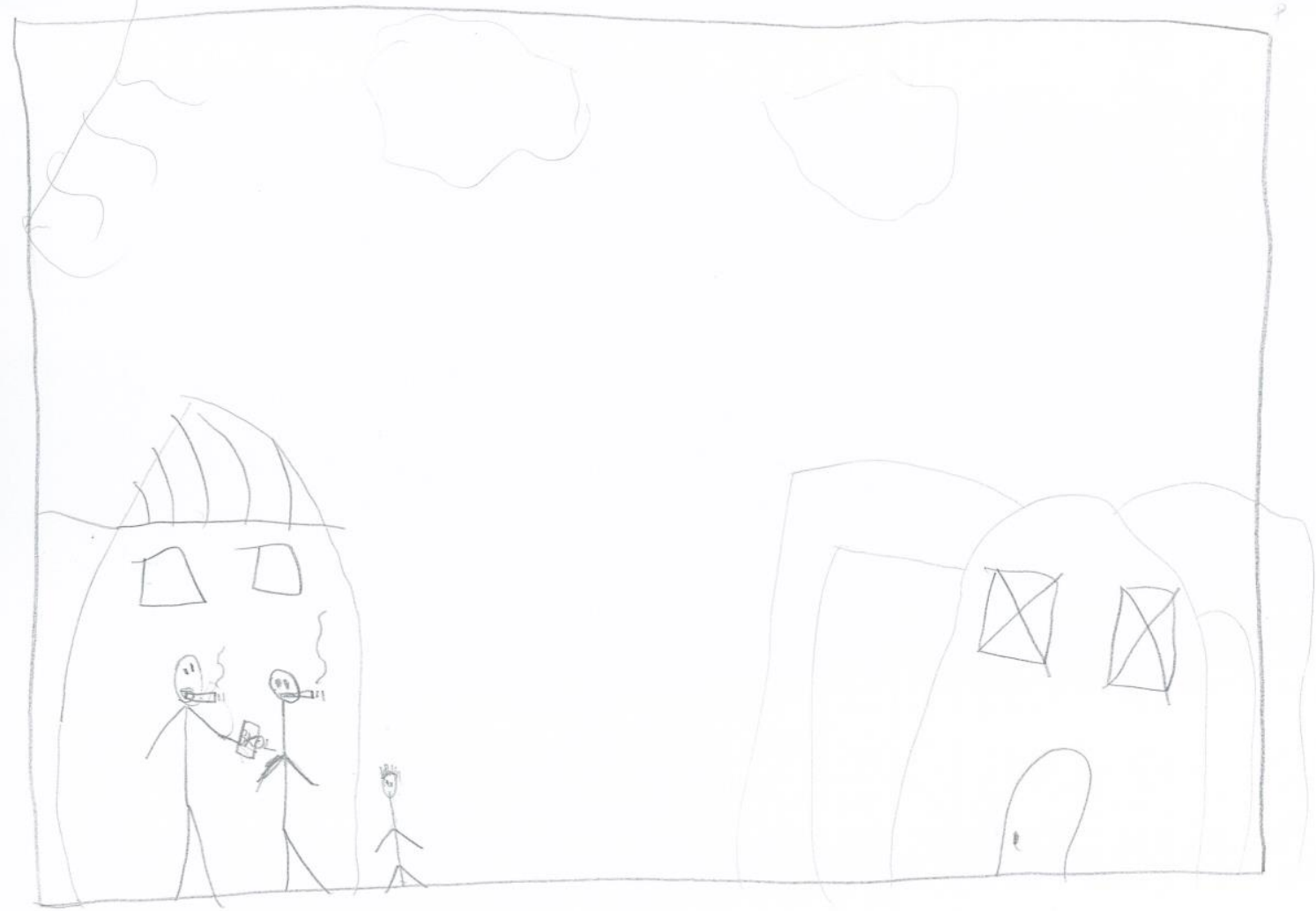


Anexo 13. Desenho Solução Jaspe

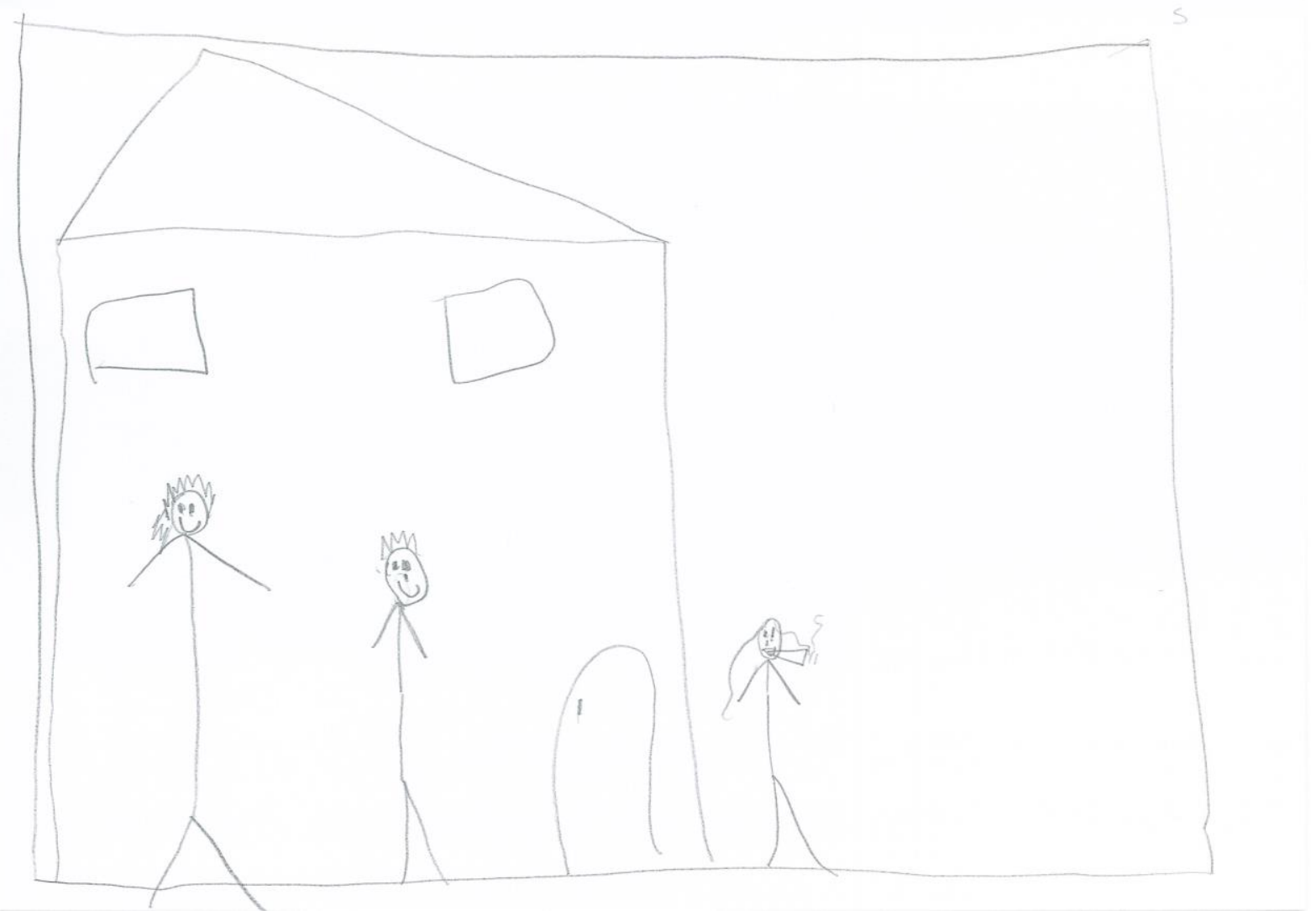


Anexo 14. Desenho Problema Cacau

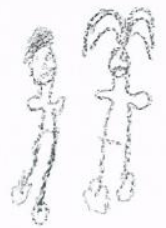


Anexo 15. Desenho Solução Cacau

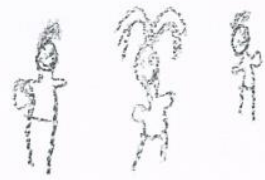


Anexo 16. Desenho Problema Jasmim A

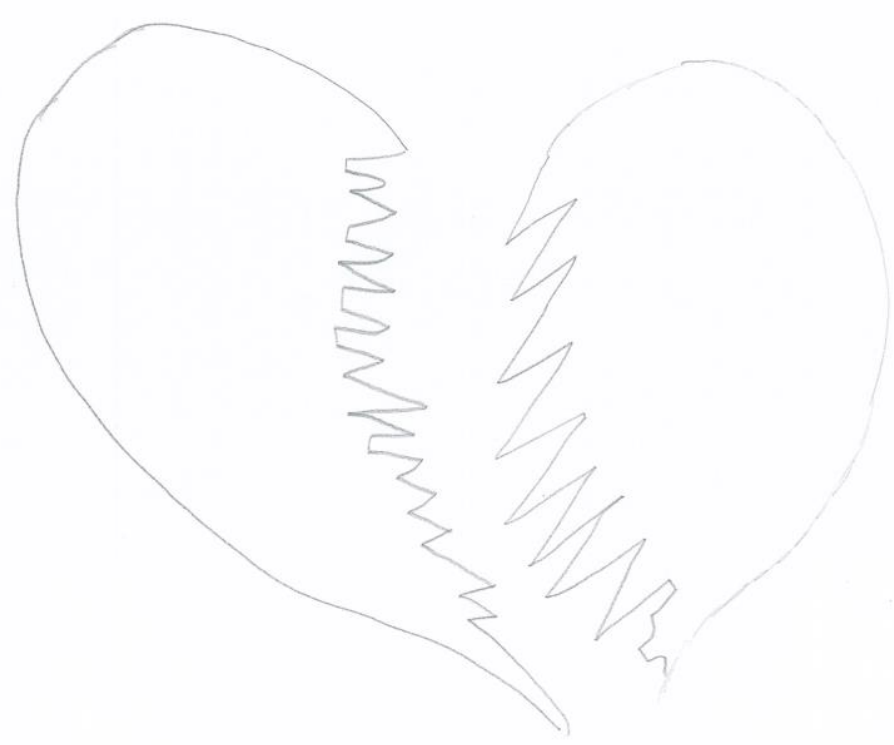


Anexo 17. Desenho Problema Jasmim B

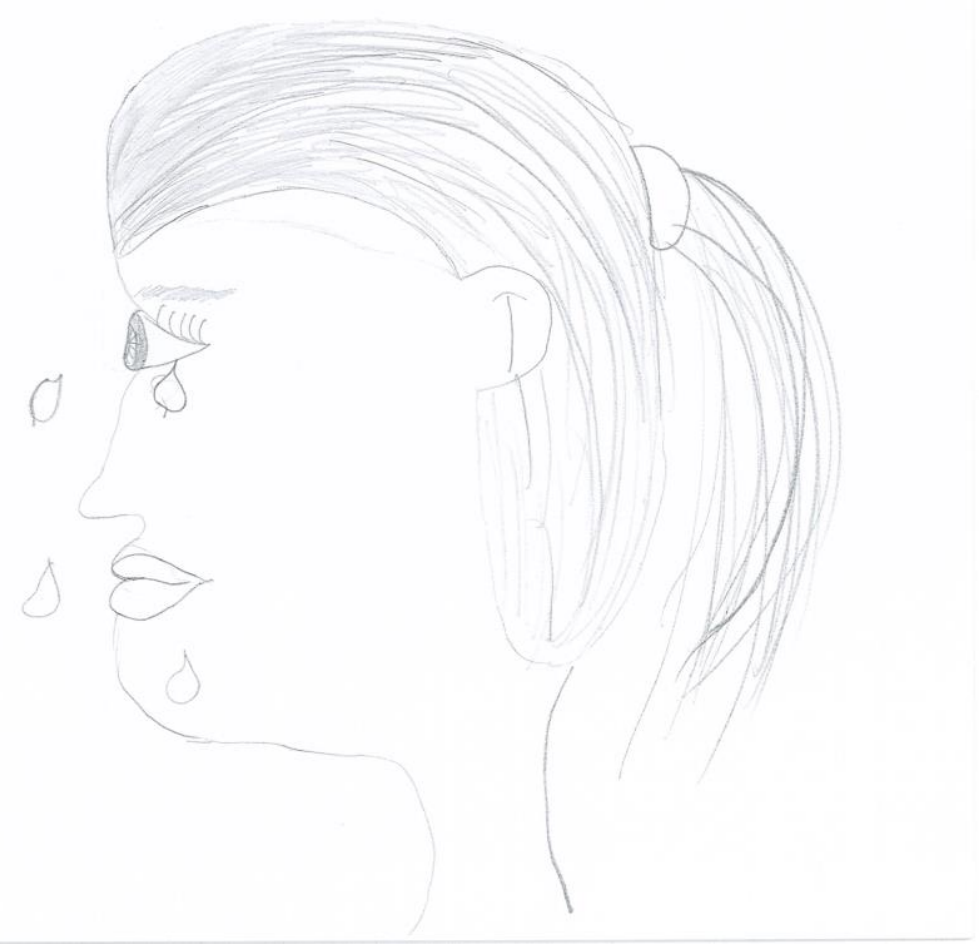


Anexo 18. Desenho Problema Jasmim C

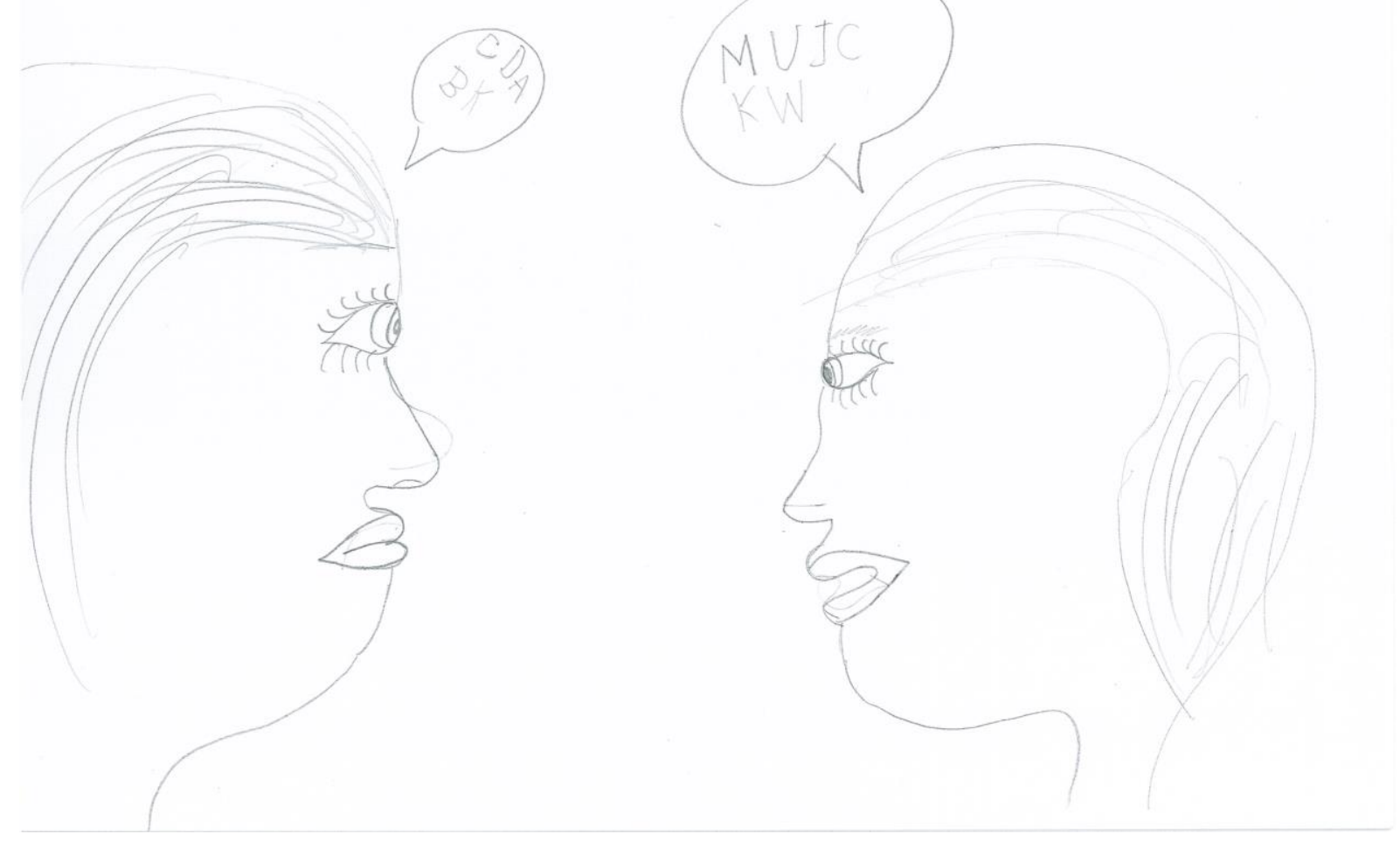


Anexo 19. Desenho Solução Jasmim A
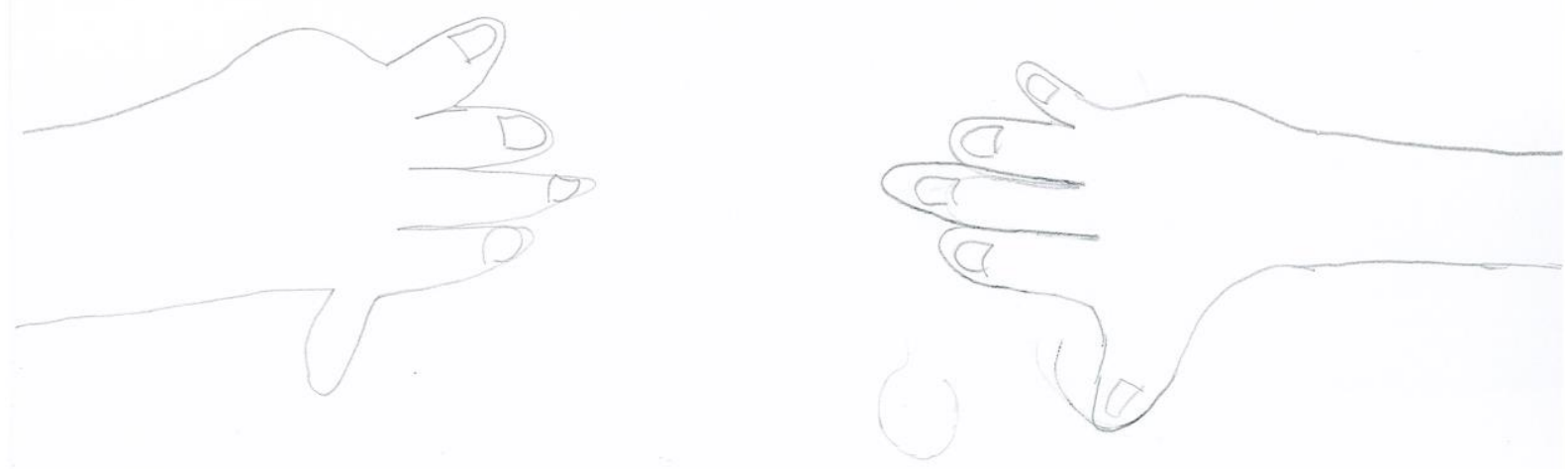
Anexo 20. Desenho Solução Jasmim B

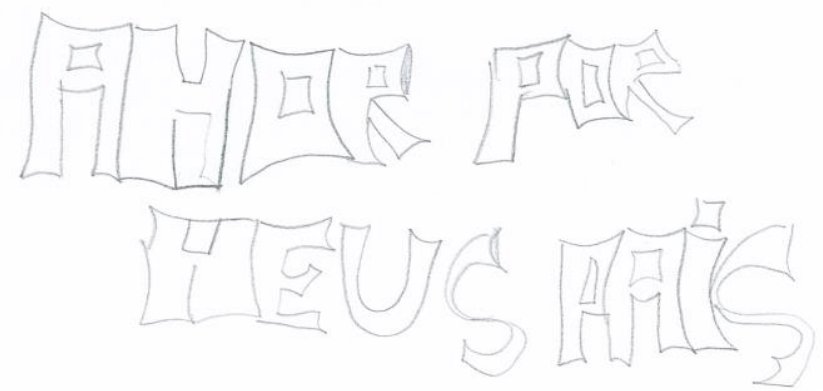


Anexo 21. Desenho Problema Yacón A 
Anexo 22. Desenho Problema Yacón B

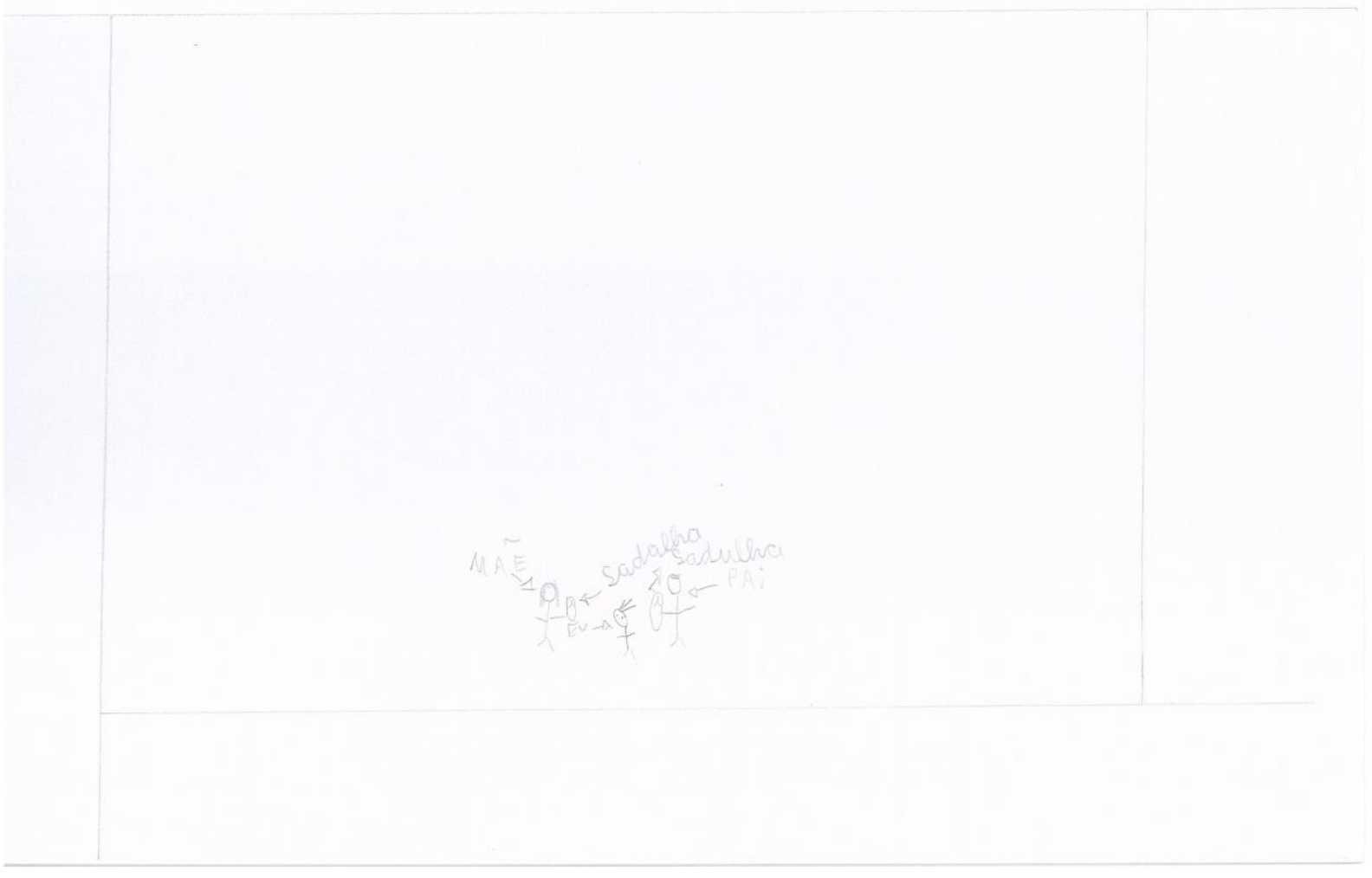


Anexo 23. Desenho Solução Yacón

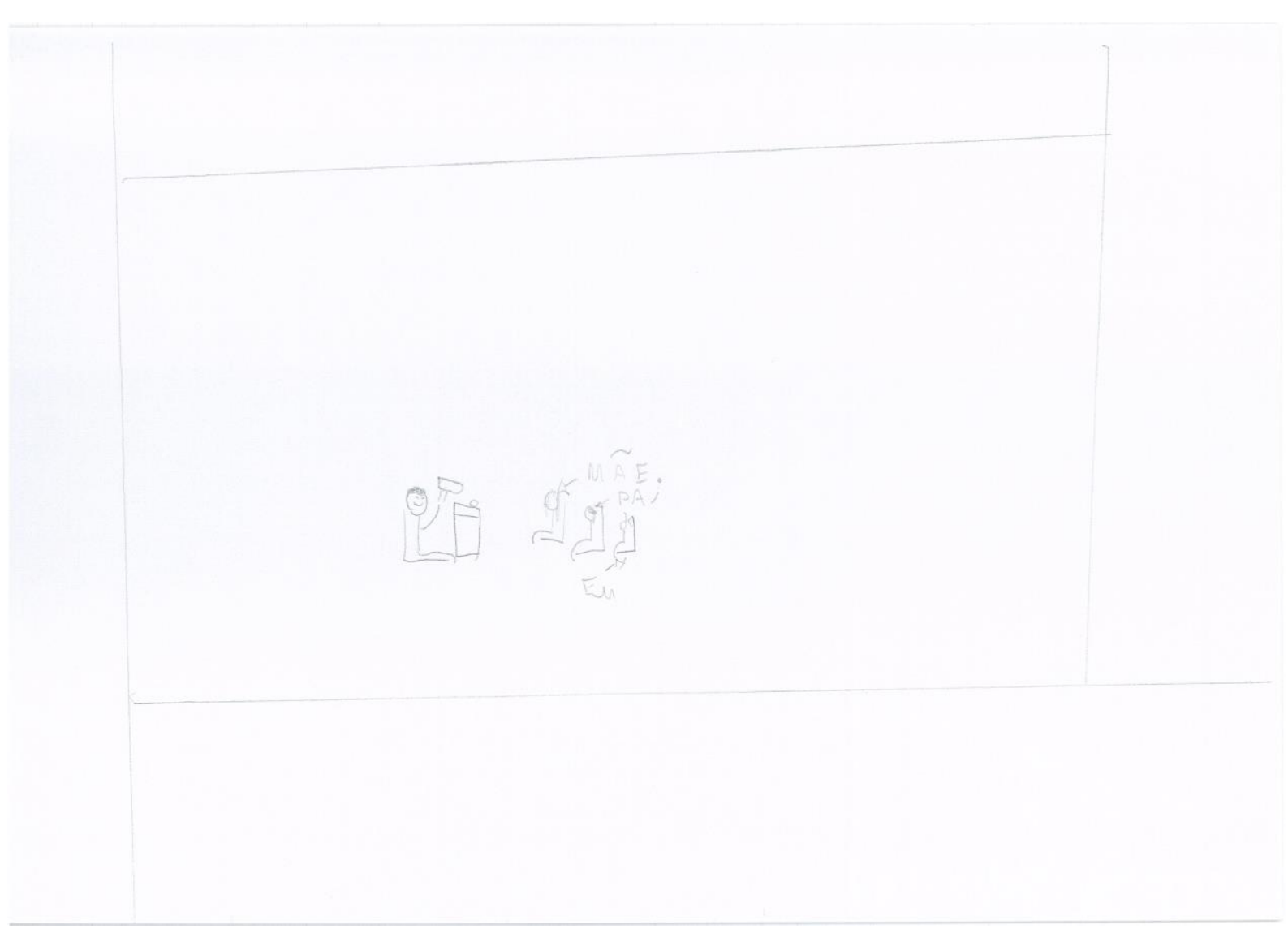


Anexo 24. Desenho Problema Natureza Yacón A 
Anexo 25. Desenho Problema Natureza Yacón B

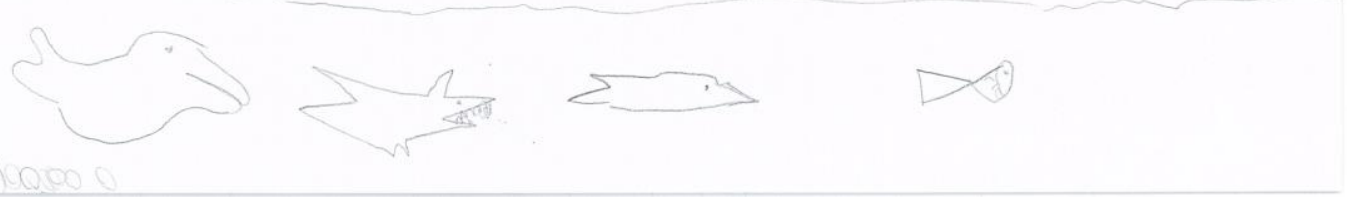


Anexo 26. Desenho Solução Natureza Yacón C 
Anexo 27. Desenho Problema Ágata
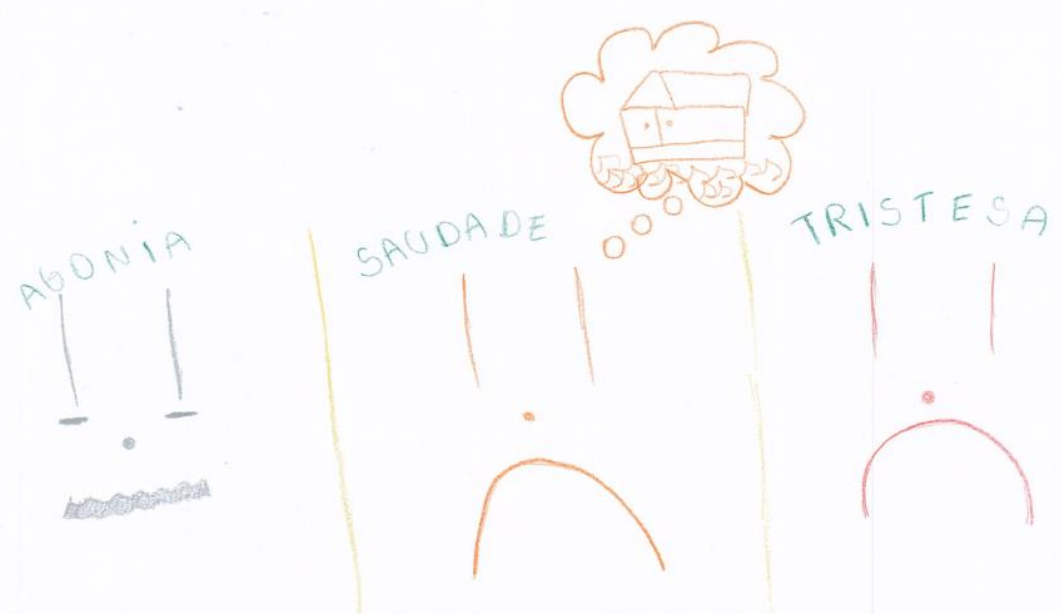
Anexo 28. Desenho Solução Ágata

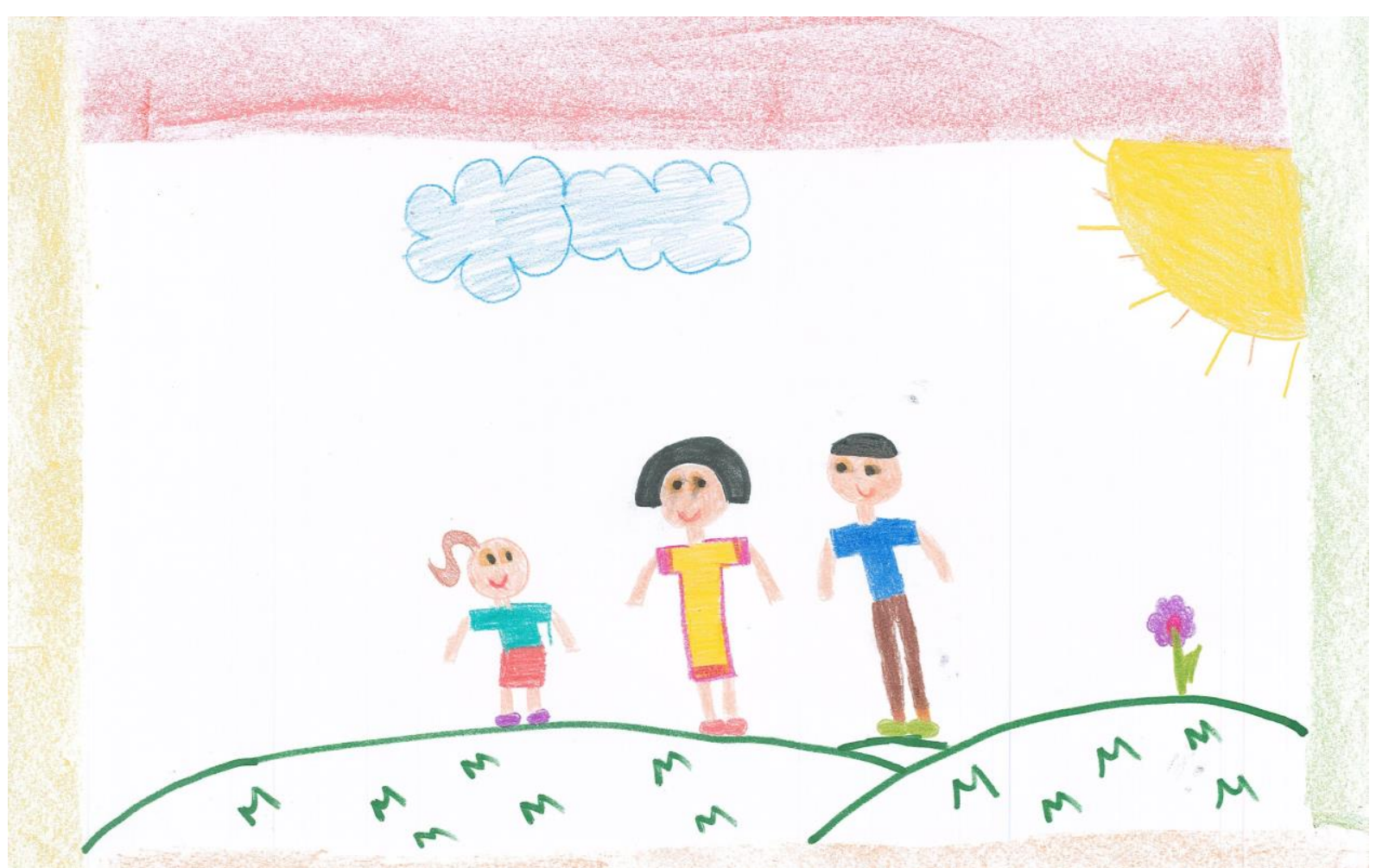


Anexo 29. Desenho Problema Berilo

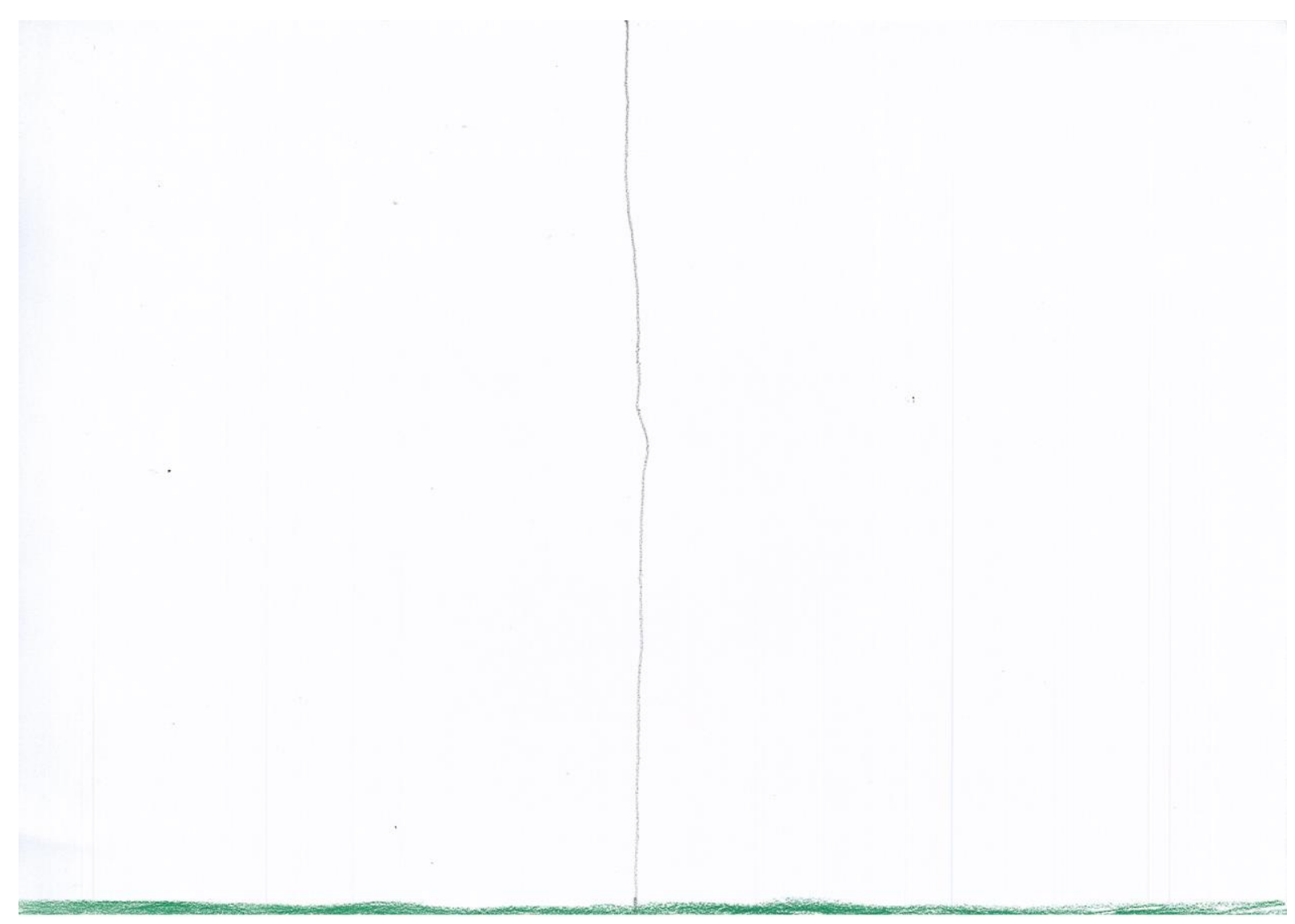


Anexo 30. Desenho Solução Berilo

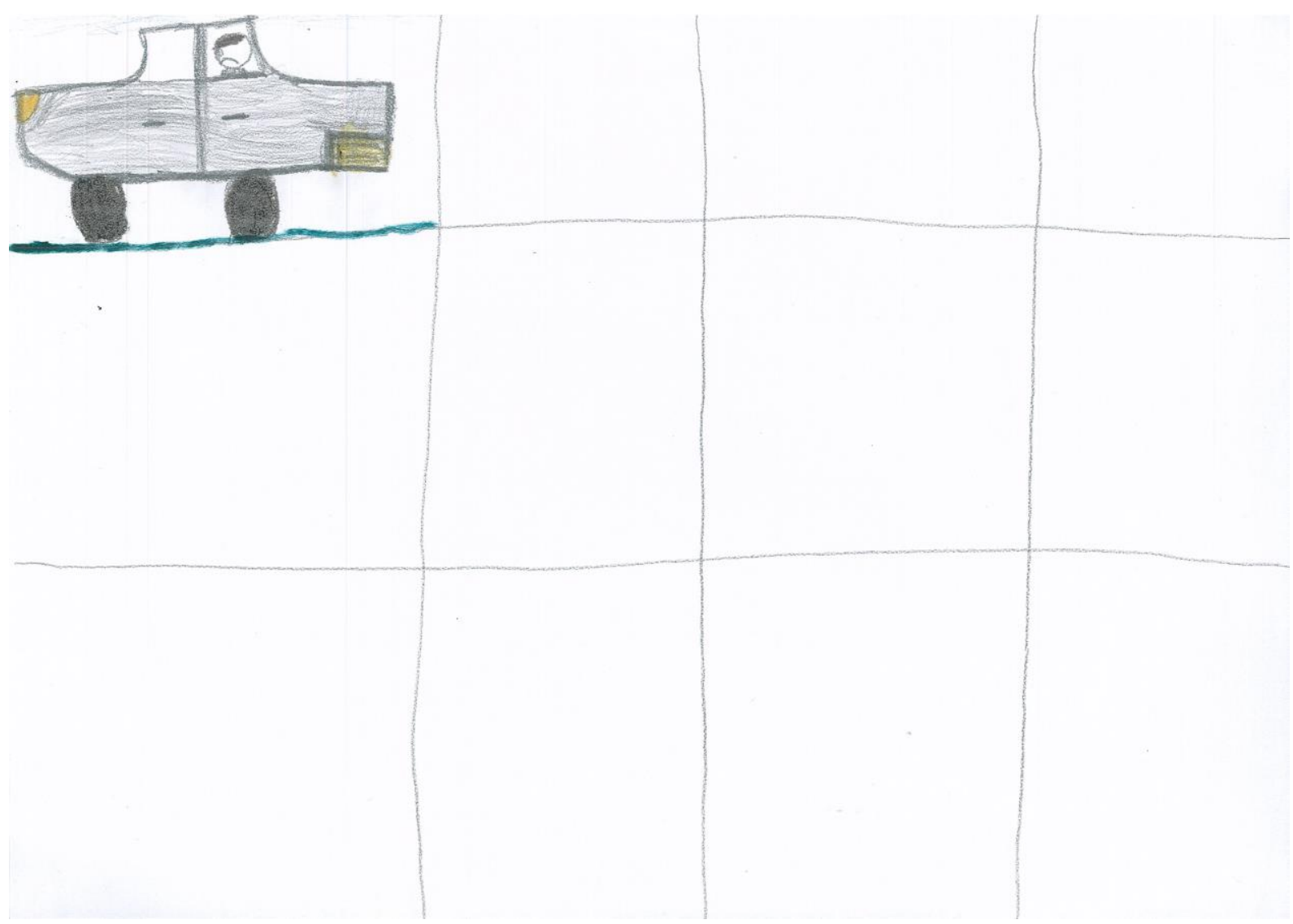


Anexo 31. Desenho Problema e Solução Esmeralda

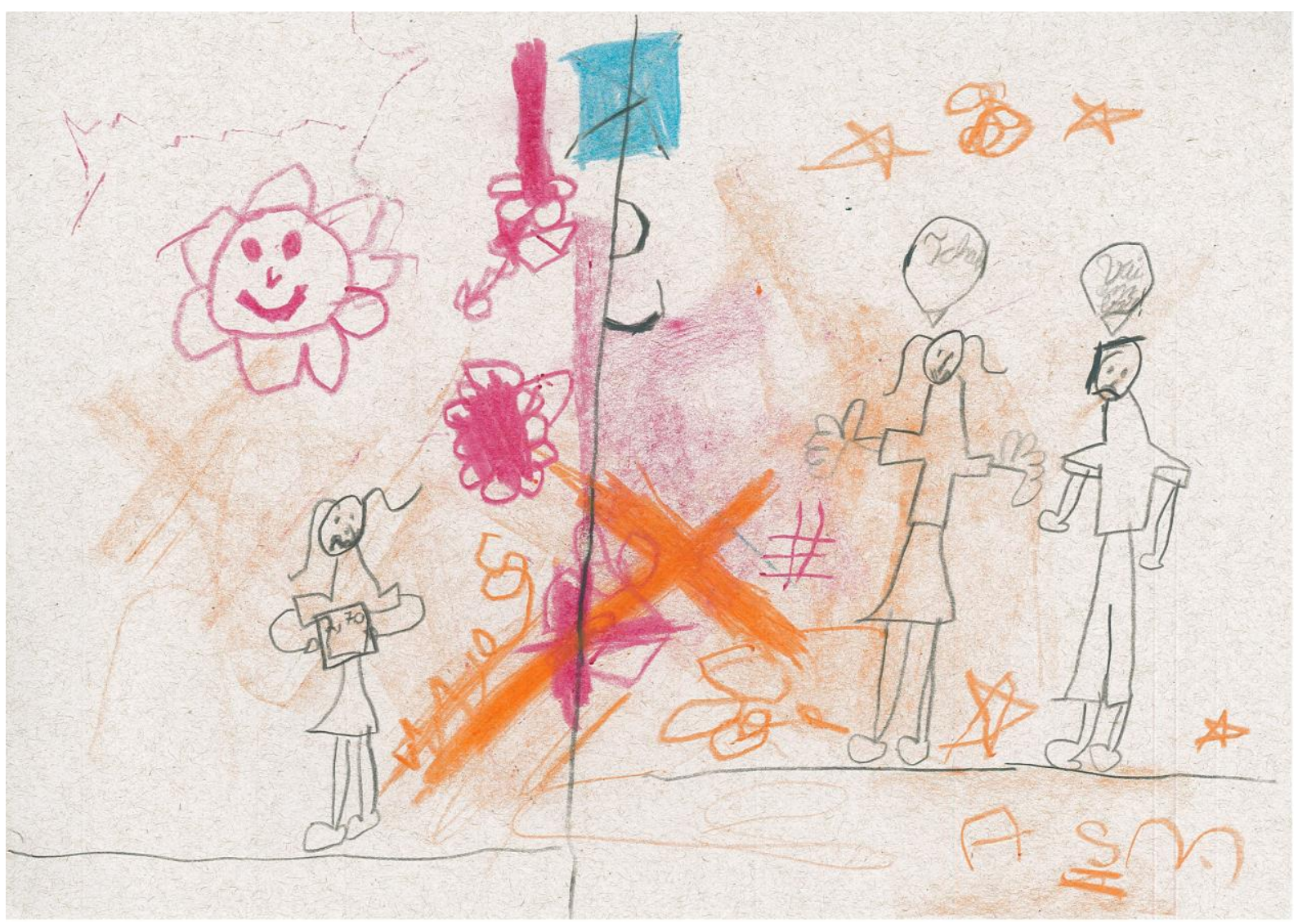


Anexo 32. Desenho Problema Natureza Jasmim A

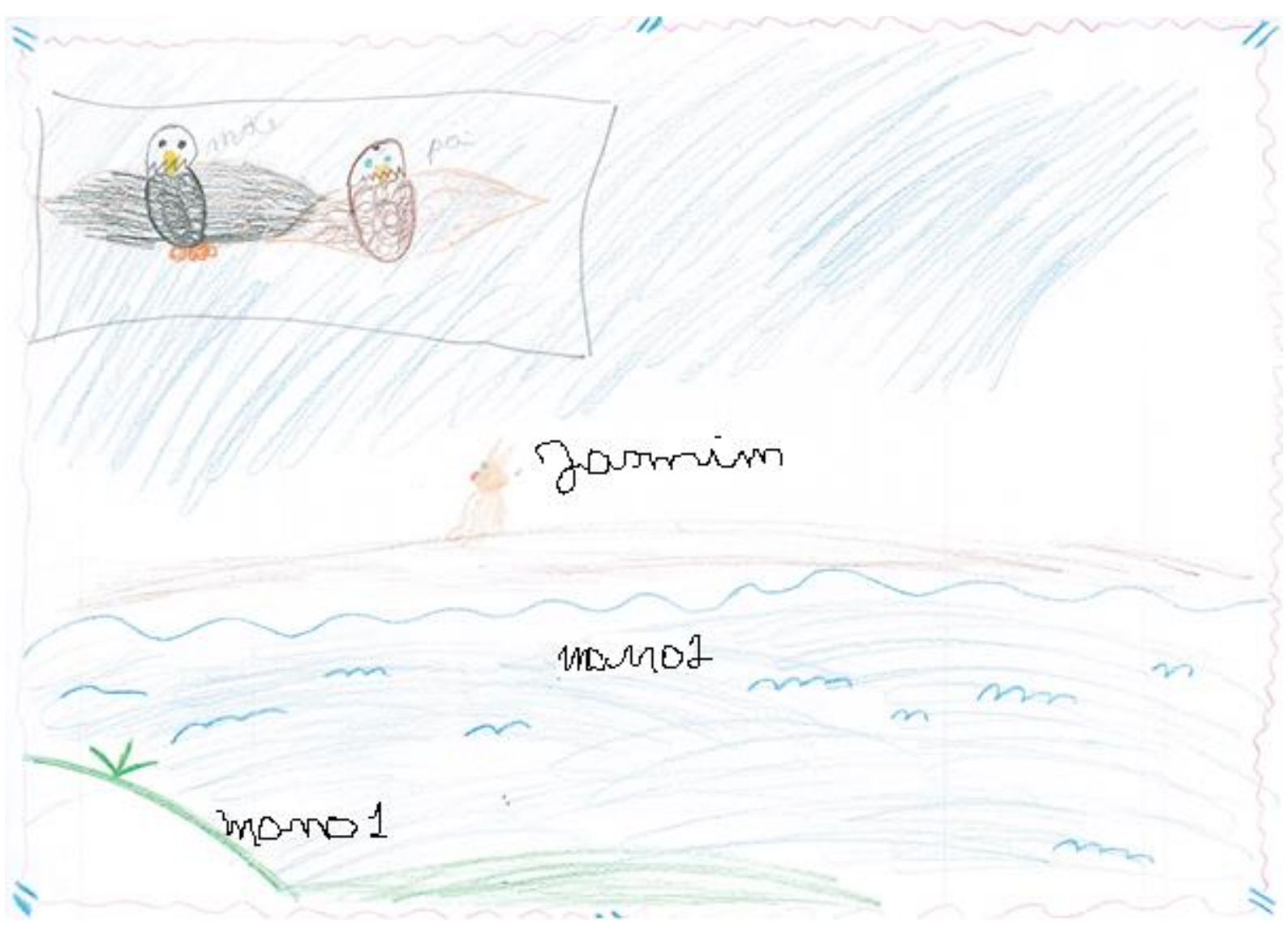


Anexo 33. Desenho Problema Natureza Jasmim B

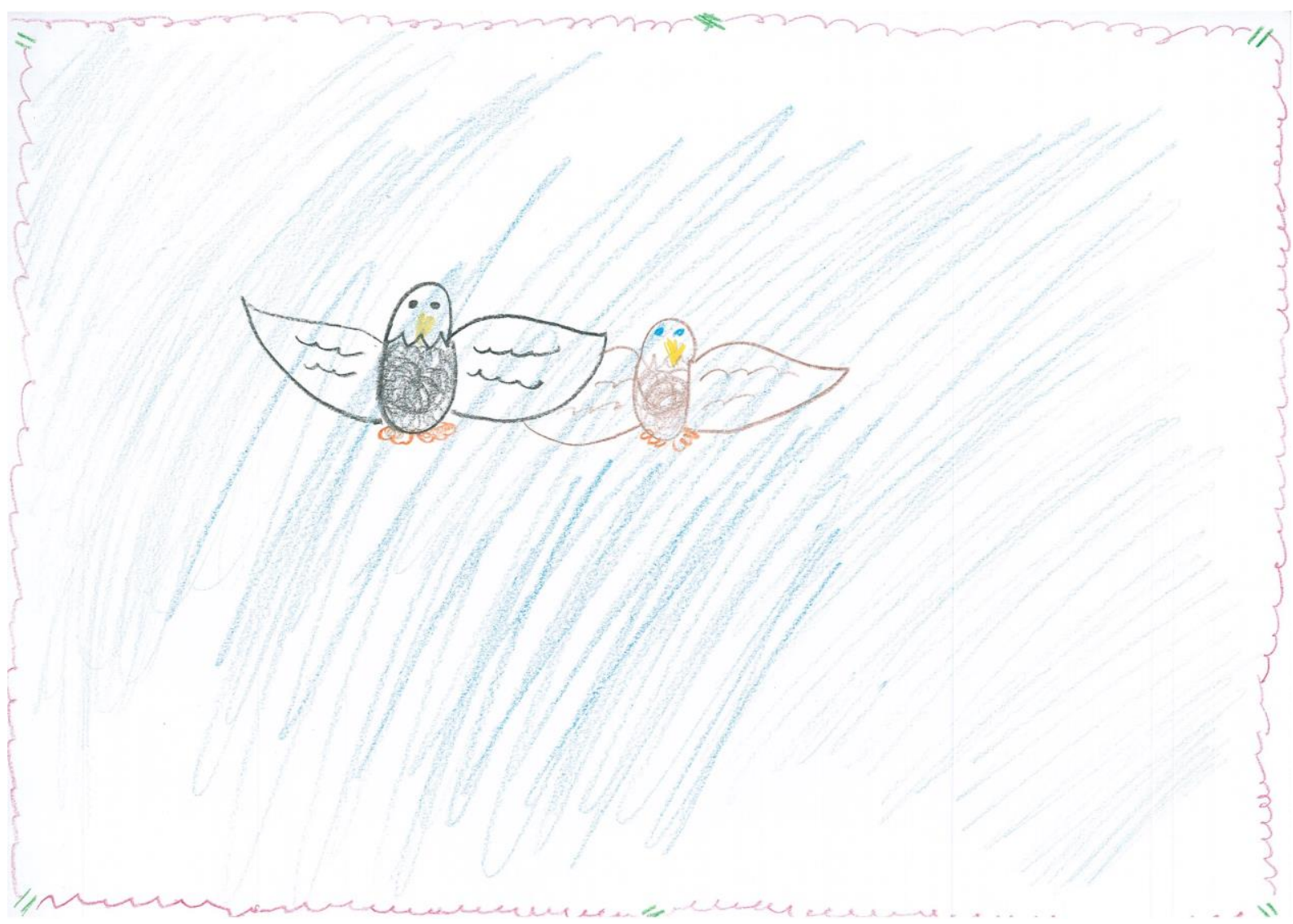


Anexo 34. Desenho Solução Natureza Jasmim C

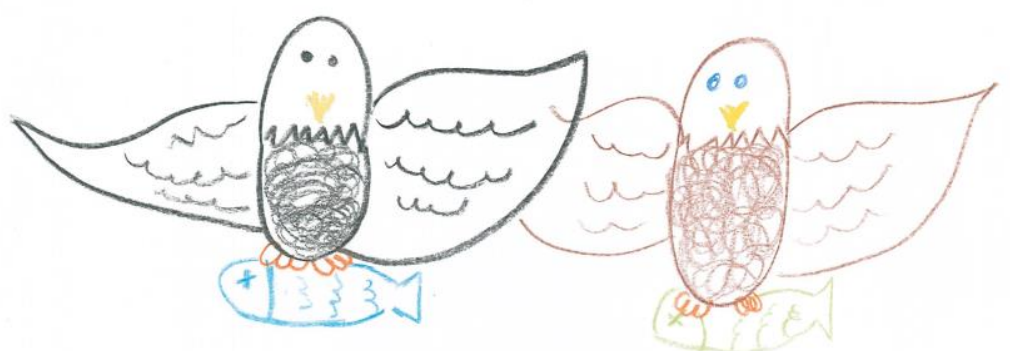

